Irradiation Performance of HTGR Fertile Fuel in HFIR Target Capsules HT-12 through HT-15: Part I-Experiment Description and Fission Product Behavior

\author{
M. J. Kania \\ T. B. Lindemer \\ M. T. Morgan \\ $\mathrm{J}$ M Robbins
}

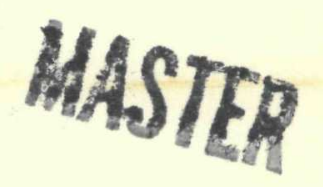




\section{Printed in the United States of America. Available from National Technical Information Service \\ U.S. Department of Commerce 5285 Port Royal Road, Springfield, Virginia 22161 \\ Price: Printed Copy $\$ 7.50$; Microfiche $\$ 3.00$}

This report was prepared as an account of work sponsored by the United States Government. Neither the United States nor the Energy Research and Development Administration/United States Nuclear Regulatory Commission, nor any of their employees, nor any of their contractors, subcontractors, or their employees, makes any warranty, express or implied, or assumes any legal liability or responsibility for the accuracy, completeness or usefulness of any information, apparatus, product or process disclosed, or represents that its use would not infringe privately owned rights. 


\section{DISCLAIMER}

This report was prepared as an account of work sponsored by an agency of the United States Government. Neither the United States Government nor any agency Thereof, nor any of their employees, makes any warranty, express or implied, or assumes any legal liability or responsibility for the accuracy, completeness, or usefulness of any information, apparatus, product, or process disclosed, or represents that its use would not infringe privately owned rights. Reference herein to any specific commercial product, process, or service by trade name, trademark, manufacturer, or otherwise does not necessarily constitute or imply its endorsement, recommendation, or favoring by the United States Government or any agency thereof. The views and opinions of authors expressed herein do not necessarily state or reflect those of the United States Government or any agency thereof. 


\section{DISCLAIMER}

Portions of this document may be illegible in electronic image products. Images are produced from the best available original document. 
Contract No. W-7405-eng-26

METALS AND CERAMICS DIVISION

Base Technology Program

Fuel Graphite Development (189a01330)

IRRADIATION PER FORMANCE OF HTGR FERTILE FUEL

IN HFIR TARGET CAPSULES HT-12 THROUGH HT-15:

PART I - EXPERIMENT DESCRIPTION AND FISSION PRODUCT BEHAVIOR

$\begin{array}{ll}\text { M. J. Kania } & \text { M. T. Morgan } \\ \text { T. B. Lindemer } & \text { J M Robbins }\end{array}$

Date Published: February 1977

This report was prepared as an account of work sponsored by the United States Government Netther the United States nor the United States Energy Research and Development Admunistration, not any of their employees, nor any of their contractors.
subcontractors, or their employees, makes any warranty, express or impled, or assumes any legal tabilly or respons or process disclosed, or represents that its use would not infrnge privately owned rights

OAK RIDGE NATIONAL LABORATORY

Oak Ridge, Tennessee 37830 operated by

UNION CARBIDE CORPORATION

for the

ENERGY RESEARCH AND DEVELOPMENT ADMINISTRATION 


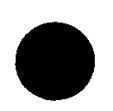

f

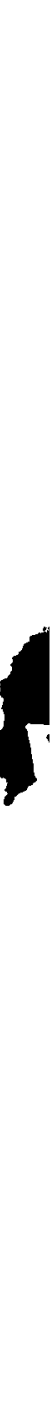

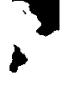

0 


\section{CONTENTS}

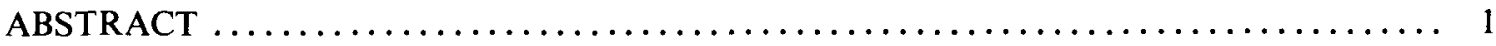

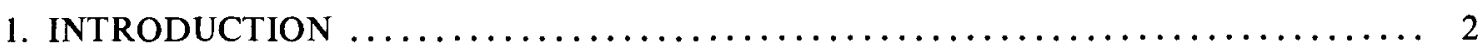

2. DESCRIPTION OF CAPSULES HT-12 THROUGH HT-15 $\ldots \ldots \ldots \ldots \ldots \ldots \ldots \ldots, 3$

2.1 Fuel......................................... 3

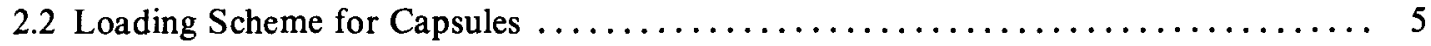

3. IRRADIATION OF CAPSULES HT-12 THROUGH HT-15 $\ldots \ldots \ldots \ldots \ldots \ldots \ldots \ldots$

3.1 Description of Facility ...................................... 8

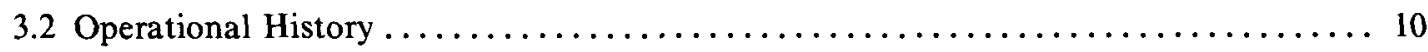

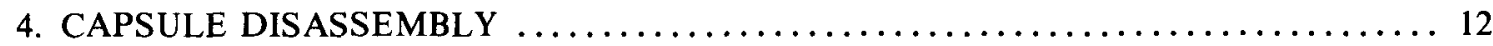

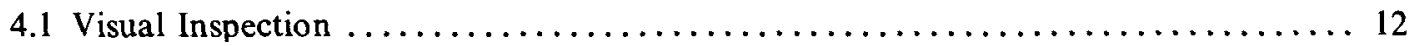

4.2 Graphite Dimensional Changes ............................ 13

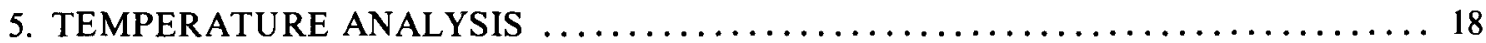

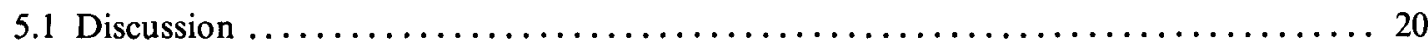

6. DETERMINATION OF BURNUP FROM FISSION

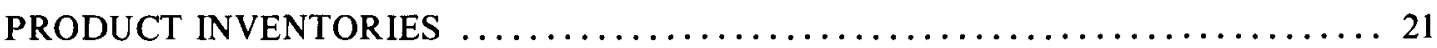

6.1 Gamma-Ray Spectroscopy of Individual Particles $\ldots \ldots \ldots \ldots \ldots \ldots \ldots \ldots \ldots \ldots \ldots \ldots \ldots \ldots \ldots \ldots$

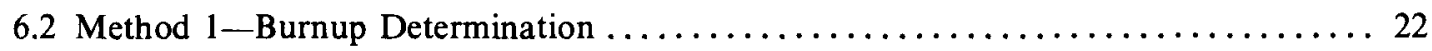

6.3 Method 2-Determination of Burnup, Effective Neutron Flux,

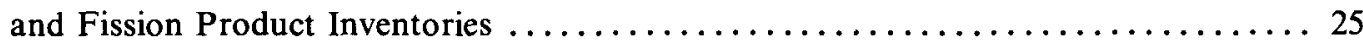

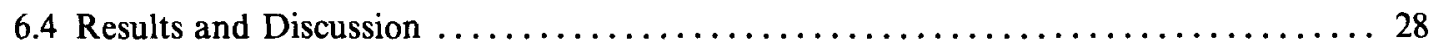

7. MEASUREMENT AND INTERPRETATION OF IN-PARTICLE

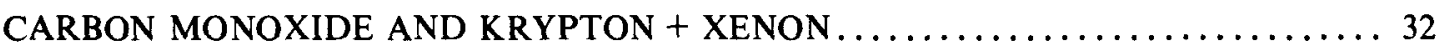

7.1 Experimental Procedures and Results.............................. 32

7.2 Krypton + Xenon Release from the Kernel......................... 33

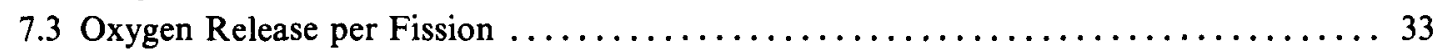

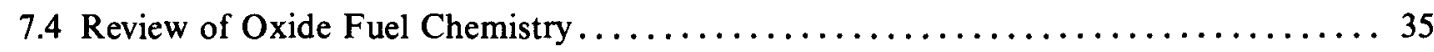

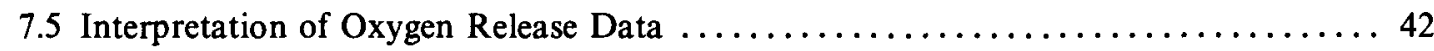

8. FAILURE DETERMINATION............................... 48

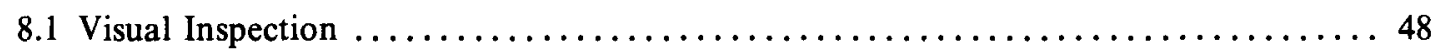

8.2 Hot Gaseous Chlorine Leaching and Associated Studies $\ldots \ldots \ldots \ldots \ldots \ldots \ldots \ldots . \ldots$

8.3 Scanning Electron Microscope Studies.......................... 52

8.4 Discussion of Results...................................... 59

9. FISSION PRODUCT RELEASE EXPERIMENTS $\ldots \ldots \ldots \ldots \ldots \ldots \ldots \ldots \ldots \ldots \ldots, 64$

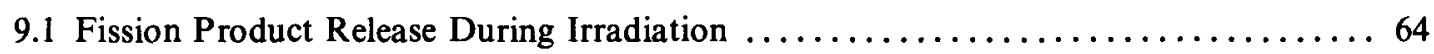

9.2 Cesium, Antimony, and Europium Release from Bare

$\mathrm{ThO}_{2}$ Kernels During Postirradiation Anneals ....................... 68

9.3 Cesium Concentration Profiles in Pyrocarbon Coatings ................... 72

9.4 Summary and Discussion of Fission Product Release Experiments on

Biso-Coated $\mathrm{ThO}_{2}$ Particles from Batches OR-1838, OR-1840, and OR-1849 ....... 75 
10. CHARACTERIZATION OF PYROCARBON COATINGS $\ldots \ldots \ldots \ldots \ldots \ldots \ldots \ldots \ldots 77$

10.1 Optical Anisotropy............................................ 77

10.2 Plasma Oxidation............................................ 77

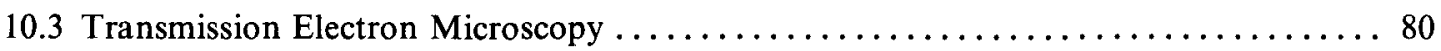

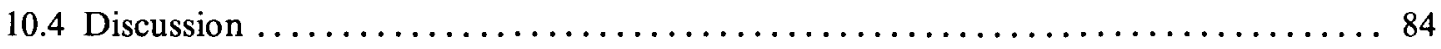

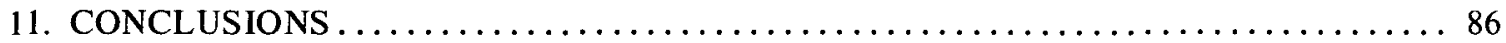

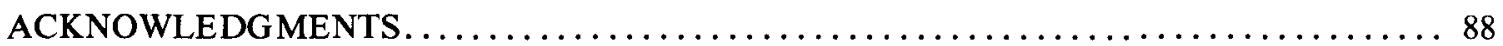

APPENDIX A-Operating Temperature Histories for Loose-Coated

Particles Irradiated in HT-12 through HT-15 . . . . . . . . . . . . . . . . . . . 89

APPENDIX B-Measured and Calculated Fission Product Inventories in Biso-Coated

$\mathrm{ThO}_{2}$ Particles from Irradiation Capsules HT-12 through HT-15 ............... 155 


\title{
IRRADIATION PERFORMANCE OF HTGR FERTILE FUEL IN HFIR TARGET CAPSULES HT-12 THROUGH HT-15: PART I-EXPERIMENT DESCRIPTION AND FISSION PRODUCT BEHAVIOR
}

\author{
M. J. Kania \\ M. T. Morgan* \\ T. B. Lindemer* \\ J M Robbins
}

\begin{abstract}
Sixteen types of Biso-coated designs, on $\mathrm{ThO}_{2}$ kernels, were irradiated in High Flux Isotope Reactor target capsules HT-12 through HT-15. This report addresses the description of the experiment and extensive postirradiation analyses and experiments to determine fertile-particle burnup, fuel coating failures, and fission product behavior. Several low-temperature isotropic (LTI) pyrocarbon coatings, which "survived" according to visual inspection, were shown to have developed permeability during irradiation. These particles were irradiated at temperatures $\cong 1250^{\circ} \mathrm{C}$ and to burnups $\geqslant 8 \%$ fission per initial heavy-metal atom (FIMA). No evidence of permeability was found in similar particles irradiated at temperatures $\cong 1550^{\circ} \mathrm{C}$ and burnups $\cong 16 \%$ FIMA. Failures due to permeability were not detectable by visual inspection but required a more extensive investigation by the $1000^{\circ} \mathrm{C}$ gaseous chlorine leaching technique.

Maximum particle surface operating temperatures were found to be approximately $300^{\circ} \mathrm{C}$ in excess of design limits of $900^{\circ} \mathrm{C}$ (low-temperature magazines) and $1250^{\circ} \mathrm{C}$ (high-temperature magazines). The extremes of high temperatures and fast neutron fluences up to $1.6 \times 10^{22}$ neutrons $/ \mathrm{cm}^{2}$ produced severe degradation and swelling of the $\mathrm{Poco}^{\dagger}$ graphite magazines and sample holders.

The amount of krypton + xenon released into the void space in the kernels of intact $\mathrm{ThO}_{2}$ particles was found to be primarily burnup dependent and reached about $90 \%$ at design burnup. Oxygen release per fission was found to be a function of temperature and burnup with the empirical expression $\mathrm{O} / f=(a+b f)$ $\exp (-Q / R T)$ representing data from $\mathrm{ThO}_{2}$ particles irradiated in the target facility and stored out-of-reactor for about two years. The oxygen release was significantly affected by the interaction of urania with sesquioxides of yttrium plus rare-earth elements. The irradiated particles showed complete retention of fission products ${ }^{106} \mathrm{Ru}$ and ${ }^{144} \mathrm{Ce}$ at the extremes of temperature and burnup, whereas ${ }^{137} \mathrm{Cs}$ and ${ }^{125} \mathrm{Sb}$ were lost under the same conditions. Cesium loss was 20 to $40 \%$ for burnups of 6 to $16 \%$ FIMA in the impermeable coatings and about $65 \%$ in particles with defective coatings at the higher temperatures. Cesium loss at the lower temperatures and burnups was $<1 \%$. Cesium diffusion coefficients in the bare kernels of the same coated particles ranged from $1 \times 10^{-17}$ to $2 \times 10^{-15} \mathrm{~cm}^{2} / \mathrm{sec}$, increasing with burnup.
\end{abstract}

*Chemical Technology Division.

$\dagger$ Grade AFX-5Q manufactured by Poco Graphite Inc., a subsidiary of Union Oil Company, Decatur, Texas. 


\section{INTRODUCTION}

An initial phase in the program of accelerated irradiation experiments is the loose-coated particle tests conducted in the target facility ${ }^{1}$ of the High Flux Isotope Reactor. ${ }^{2}$ These experiments, commonly known as the HT-series, screen various coated particle designs and fuel rod matrix designs at, or in excess of, temperatures and fast neutron fluences accumulated in a commercial HTGR. Because of the high neutron fluxes in the target region, full fluences of $8 \times 10^{21}$ neutrons $/ \mathrm{cm}^{2}(E>0.18 \mathrm{MeV})$ can be achieved in three to four months as compared with the required six years in an HTGR.

This experiment was made up of four target capsules designated HT-12, -13, -14, and -15 . It was designed to test a series of 16 batches of Biso-coated $\mathrm{ThO}_{2}$ particles at peak temperatures of 900 and $1250^{\circ} \mathrm{C}$, to burnup and fast neutron exposures up to twice the HTGR design requirements. Nine of these batches were coated by Oak Ridge National Laboratory, and the remaining seven by General Atomic Company. ${ }^{3}$ The ORNL-designed coatings were selected with the use of the STRETCH ${ }^{4}$ computer code so that some particles would fail while others survived. The capsules were irradiated for two, four, six, and seven HFIR cycles respectively.

The primary objectives of this experiment were:

1. to test selected Biso-coated $\mathrm{ThO}_{2}$ particles at conditions that would induce predictable particle failure and therby establish minimal coating engineering design criteria;

2. to determine numerical values for material constants (as far as possible) required in the stress analysis code, STRETCH.

In addition, several selected batches of particles were extensively investigated to determine: (1) burnup, cesium retention by the particle, and internal gas pressures; (2) failure and fission product release in Biso-coated $\mathrm{ThO}_{2}$ particles; (3) pyrocarbon coating characterization.

Minimal coating engineering design criteria for Biso-coated $\mathrm{ThO}_{2}$ particles were not established in this experiment. This was due to the inability to examine all irradiated coating batches with experimental techniques necessary to establish, with certainty, failed particles in each batch. Because of the uncertainty, both in failure determination and in the cause of failure, it was not possible to correlate the predicted results, using the STRETCH code, with the experimental results. Thus, no results are reported for the material constants required in the STRETCH code. The results of work in progress to determine coating integrity and to correlate the STRETCH model analysis to experimental data will be reported in TM-5306.

\section{References}

1. B. H. Montgomery, "Irradiation Tests in the HFIR Target Facility," Gas-Cooled Reactor Programs Ann. Prog. Rep. Dec. 31, 1972, ORNL-4911, pp. 113-15.

2. R. D. Cheverton and T. M. Sims, HFIR Core Nuclear Design, ORNL-4621 (July 1971).

3. HTGR Fuels and Core Development Program; Q. Prog. Rep. Aug. 30, 1974,GA-A13126, pp. 52-74.

4. J. W. Prados and T. G. Godfrey, STRETCH-A Computer Program for Predicting CoatedParticle Irradiation Behavior; Modification IV, December 1967, ORNL/TM-2127 (April 1968). 


\section{DESCRIPTION OF CAPSULES HT-12 THROUGH HT-15}

This experiment consisted of four target capsules designated HT-12, -13, -14, and -15. Each capsule contained four tapered graphite magazines each supporting coated particle samples in small graphite crucibles. Two of the magazines were designed for a graphite crucible surface temperature of $1250^{\circ} \mathrm{C}$, and the remaining two for a temperature of $900^{\circ} \mathrm{C}$. The four capsules were designed for two, four, six, and eight HFIR cycles to achieve a fast neutron exposure from $2 \times 10^{21}$ to $18 \times 10^{21}$ neutrons $/ \mathrm{cm}^{2}(E>$ $0.18 \mathrm{MeV}$ ). Burnup in the $\mathrm{ThO}_{2}$ would range from 2 to $20 \%$ FIMA.

The design of an HT capsule used in loose-coated particle experiments is illustrated in Fig. 2.1. The active test space is a right circular cylinder approximately $0.51 \mathrm{~m}(20.0 \mathrm{in}$.) long by $13.46 \mathrm{~mm}(0.53 \mathrm{in}$.) in diameter centered about the reactor horizontal midplane (HMP). Each capsule contained 52 Poco graphite cylindrical sample holders of nominal dimensions $6.985 \mathrm{~mm}(0.275 \mathrm{in}$.) long by $9.779 \mathrm{~mm}(0.385$ in.) in diameter. Thirty-two contained Biso-coated $\mathrm{ThO}_{2}$ particles, and the remaining 20 contained lowenriched $(7 \%)$ uranium particles. The uranium particles were included as the initial heat source and to flatten axial temperature distribution. Thirteen sample holders, each separated by a $0.0127-\mathrm{mm}$-thick (0.0005-in.) zirconium foil, were loaded into each of four tapered Poco graphite magazines-eight containing $\mathrm{ThO}_{2}$ particles and five containing uranium particles. End plugs were placed in the top and bottom of each magazine, with those nearest to the HMP being loaded with uranium particles. Figure 2.2 shows the Poco graphite particle sample holder and magazine. A total of 16 fertile-particle sample holders were irradiated in the high-temperature, high-flux regions nearest the HMP, and 16 were irradiated in the low-temperature, low-flux regions located near the ends of the capsule. The four completed magazines were then placed in an aluminum primary containment vessel $13.030 \mathrm{~mm}(0.513$ in.) in inside diameter by $16.137 \mathrm{~mm}(0.655 \mathrm{in}$.) in outside diameter. With the upper and bottom caps attached, the overall length of the capsule was $0.9 \mathrm{~m}$ (35.0 in.). Each capsule was evacuated and bakedout at $300^{\circ} \mathrm{C}$ for $4 \mathrm{hr}$, backfilled with argon, and sealed.

\subsection{Fuel}

\subsubsection{Coated Particle Design}

The fertile particle makes up $80 \%$ or more of the coated particle volume in current fuel rod designs for HTGRs. The fertile particle design consists of two-layer (Biso) coatings primarily for economic reasons. The particle configuration for the Biso-coating design consists of a fuel kernel successively coated with a low-density buffer layer and a high-density isotropic carbon layer (LTI). Important variables in the coating design, which are necessary to maintain fuel particle integrity, are the total thickness of the coating layers, thickness ratios, the creep coefficient, and the outer pyrocarbon anisotropy.

To meet the objectives of this experiment, it was necessary to design particle coatings so that some would fail and others survive. It was also necessary to be able to examine the particles after selected intervals of accrued fast fluence $(E>0.18 \mathrm{MeV})$. The reference particle design ${ }^{1}$ for this experiment was a $500-\mu \mathrm{m}$-diam $\mathrm{ThO}_{2}$ kernel and a Biso coating consisting of an 85- $\mu \mathrm{m}$-thick buffer layer and a $75-\mu \mathrm{m}$ thick outer isotropic carbon layer. This same fertile particle design is currently specified for initial and recycle HTGR fuel.

Variations on the reference coating design were selected for testing on the basis of irradiation performance predicted by the STRETCH computer code. The two most sensitive physical variables used in the code were the creep coefficient and the outer carbon layer anisotropy. 


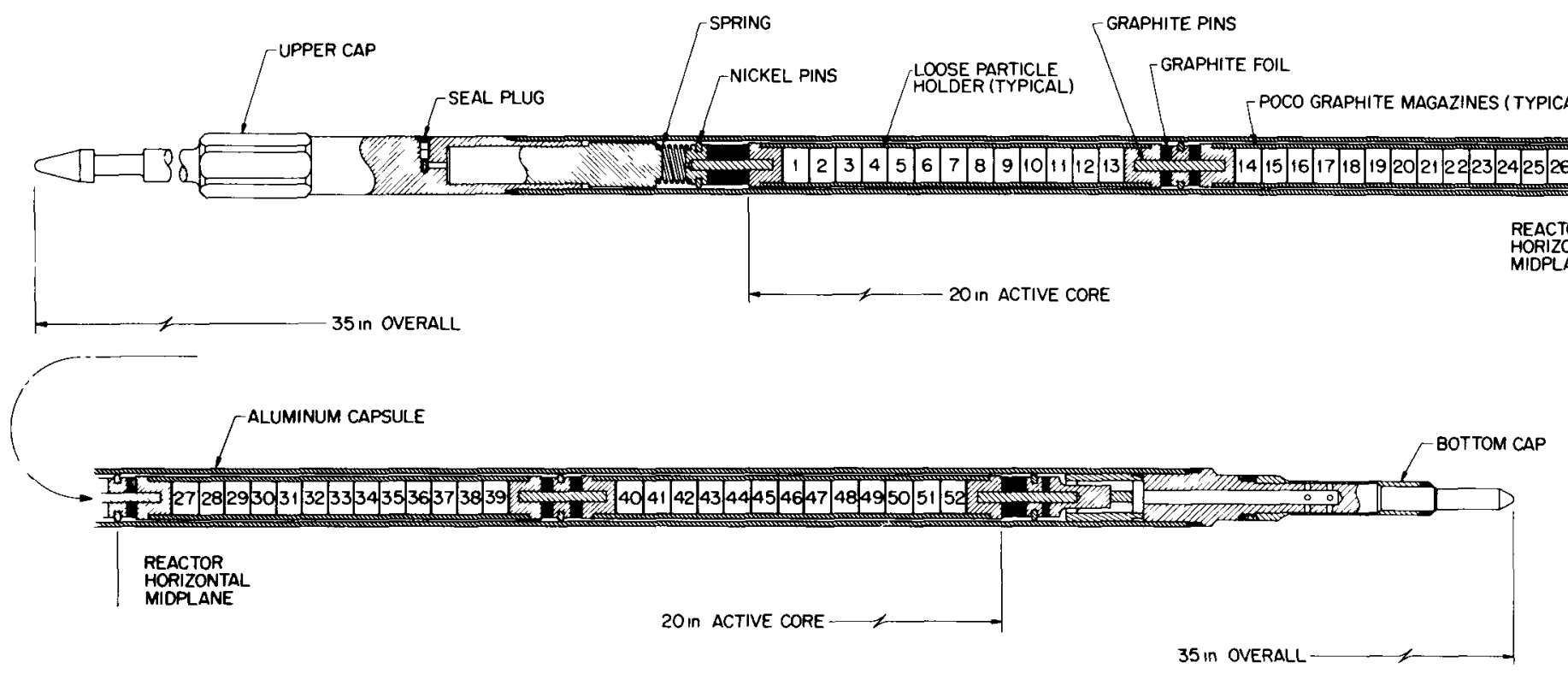

Fig. 2.1. Target capsule typical of HT-12, $-13,-14$, and -15 . 


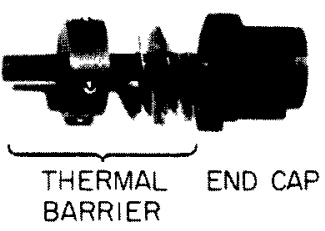

4

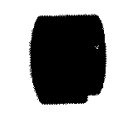

PARTICLE

SAMPLE

HOLDER

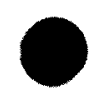

SCREW CAP

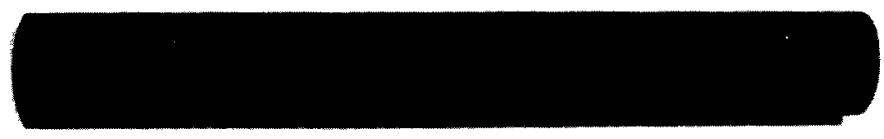

GRAPHITE MAGAZINE

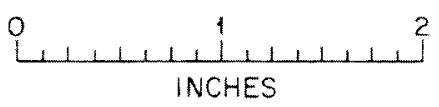

FUELED END CAP

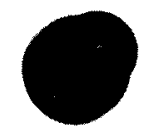

NCHES

Fig. 2.2. Graphite sample holder and magazine for capsules HT-12 through HT-15.

Biso-coating designs were calculated using nominal neutron flux and temperature values. A creep coefficient of $10^{-27} \mathrm{in}$./(in.-psi-neutrons $/ \mathrm{cm}^{2}$ ) was assumed for the calculations, and the effect of variations by a factor of 5 were studied. The Bacon anisotropy factor was assumed to be 1.05 , but values of 1.00 to 1.15 were also used in the calculations. A value for the densification constant equal to 0.046 per $10^{20}$ neutrons was used in all of the calculations. A failure criteria of $20,000 \mathrm{psi}$ of tangential stress on the outer LTI was assumed for each design. Within these parameters the particles were predicted to fail at the rate of two types for each irradiation cycle in the HFIR.

\subsubsection{Preparation of Test Samples}

The $\mathrm{ThO}_{2}$ kernels for the experiment were screened from a large batch of sol-gel-derived ${ }^{2}$ microspheres so that the diameter distribution of each kernel batch would have a standard deviation $\leqslant 7$ $\mu \mathrm{m}$. Both $400-$ and $500-\mu \mathrm{m}$-diam kernels were used. A total of 16 particle batches were prepared. Nine of these were coated by ORNL, and the remaining seven by General Atomic. All of the ORNL particle batches were coated in a 25.4-mm-diam (1.0-in.) coating furnace. The buffer layers were deposited at $1200^{\circ} \mathrm{C}$, using a coating gas composition of $75 \% \mathrm{C}_{2} \mathrm{H}_{2}$ and $25 \%$ helium. The outer LTI coatings were deposited at $1400^{\circ} \mathrm{C}$, using a coating gas concentration of $75 \% \mathrm{C}_{3} \mathrm{H}_{6}$ and $25 \%$ helium. Deposition rates for each ORNL coating along with the characterization of each particle batch are described in Table 2.1. All ORNL particle batches were annealed at $1800^{\circ} \mathrm{C}$ in an argon environment for 30 minutes prior to irradiation.

\subsection{Loading Scheme for Capsules}

As previously described, each capsule was identical and contained 52 sample holders: 32 filled with $\mathrm{ThO}_{2}$ particles and 20 filled with uranium particles. The 16 types of particles were distributed as indicated in Table 2.2 such that each of the four magazines would contain eight $\mathrm{ThO}_{2}$ particle holders and five uranium holders. This allowed each particle batch to be irradiated in one position in each of the high-and low-temperature regions. The number of $\mathrm{ThO}_{2}$ particles irradiated was 75 per sample holder in 
Table 2.1. Coating deposition rates and characterization of coated particles in capsules HT-12 through HT-15

\begin{tabular}{|c|c|c|c|c|c|c|c|c|}
\hline \multirow{3}{*}{ Batch } & \multirow{2}{*}{\multicolumn{2}{|c|}{$\begin{array}{c}\text { Deposition rate } \\
(\mu \mathrm{m} / \mathrm{min}) \\
\end{array}$}} & \multirow{3}{*}{$\begin{array}{c}\text { Kernel } \\
\text { diameter }^{b} \\
(\mu \mathrm{m})\end{array}$} & \multicolumn{2}{|c|}{ Buffer } & \multicolumn{2}{|c|}{ LTI } & \multirow{3}{*}{$\mathrm{OPTAF}^{e}$} \\
\hline & & & & \multirow{2}{*}{$\begin{array}{l}\text { Thickness }^{b} \\
\quad(\mu \mathrm{m})\end{array}$} & \multirow{2}{*}{$\begin{array}{c}\text { Density }{ }^{c, d} \\
\left(\mathrm{~g} / \mathrm{cm}^{3}\right)\end{array}$} & \multirow{2}{*}{$\begin{array}{c}\text { Thickness }^{b} \\
(\mu \mathrm{m})\end{array}$} & \multirow{2}{*}{$\begin{array}{l}\text { Gradient } \\
\text { density } \\
\left(\mathrm{g} / \mathrm{cm}^{3}\right)\end{array}$} & \\
\hline & Buffer & LTI & & & & & & \\
\hline OR-1749 & 32.4 & 24 & $402 \pm 3.04$ & $32.9 \pm 7.7$ & 1.1 & $36.4 \pm 3.2$ & 1.92 & $1.03^{f}$ \\
\hline OR-1826 & 31.9 & 20.4 & $402 \pm 3.04$ & $21.4 \pm 3.3$ & 1.1 & $30.6 \pm 3.89$ & 2.01 & $g$ \\
\hline OR-1830 & $\mathrm{ND}^{h}$ & 19.8 & $402 \pm 3.04$ & $1 \pm \mathrm{ND}^{h}$ & 1.1 & $38.1 \pm 4.56$ & 2.01 & $g$ \\
\hline OR-1 837 & $\mathrm{ND}^{h}$ & 20.7 & $402 \pm 3.04$ & $1 \pm \mathrm{ND}^{h}$ & 1.1 & $24.4 \pm 2.8$ & 2.02 & $f, g$ \\
\hline OR-1 838 & 37.0 & 20.1 & $402 \pm 3.04$ & $32.3 \pm 3.9$ & 1.1 & $63.8 \pm 4.1$ & 1.96 & $1.02^{f}$ \\
\hline OR-1 840 & 57.0 & 19.4 & $402 \pm 3.04$ & $24.6 \pm 3.4$ & 1.1 & $50.1 \pm 4.3$ & 2.01 & $g$ \\
\hline OR-1846 & 50.0 & 21.2 & $402 \pm 3.04$ & $20.3 \pm 3.2$ & 1.1 & $21.2 \pm 2.29$ & 1.99 & $g$ \\
\hline OR-1849 & 56.0 & 21.4 & $508 \pm 1.66$ & $79.4 \pm 6.7$ & 1.1 & $74.7 \pm 4.3$ & 1.99 & $1.02^{f}$ \\
\hline OR-1850 & 72.0 & 19.9 & $508 \pm 1.66$ & $44.5 \pm 5.6$ & 1.1 & $48.1 \pm 3.5$ & 1.99 & $g$ \\
\hline $4252-00$ & & & $405 \pm 9.0$ & $81.0 \pm 6.1$ & 1.26 & $76.0 \pm 5.9$ & 2.00 & 1.14 \\
\hline $4252-01$ & & & $487 \pm 14.7$ & $61.0 \pm 7.4$ & 1.11 & $76.0 \pm 8.3$ & 2.02 & 1.16 \\
\hline $4252-02$ & & & $508 \pm 9.6$ & $83.0 \pm 6.9$ & 1.08 & $75.0 \pm 7.5$ & 1.84 & 1.07 \\
\hline $4252-03$ & & & $501 \pm 14.3$ & $92.0 \pm 9.8$ & 1.08 & $67.0 \pm 5.6$ & 2.00 & $i$ \\
\hline $4252-06$ & & & $514 \pm 8.7$ & $80.0 \pm 6.3$ & 1.10 & $74.0 \pm 6.0$ & 1.82 & 1.14 \\
\hline $4252-07$ & & & $485 \pm 22.4$ & $46.0 \pm 4.5$ & 1.03 & $50.0 \pm 4.1$ & $1.96^{j}$ & 1.20 \\
\hline $4252-08$ & & & $499 \pm 16.5$ & $39.0 \pm 6.2$ & 1.08 & $119.0 \pm 11.1$ & 1.95 & 1.14 \\
\hline
\end{tabular}

${ }^{a}$ Deposition rates are quoted for ORNL particles only.

$b$ Mean value \pm standard deviation.

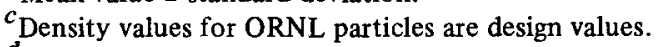

${ }^{d}$ General Atomic density measurements made on parent particle batch or calculated.

${ }^{e}$ OPTAF values obtained from procedure described in D. W. Stevens, "Optical Anisotropy in Nearly Isotropic Pyrolytic Carbons," pp. 167-68 in 11th Biennial Conference on Carbon, June 4-8, 1973, CONF-730601, Sponsored by the American Carbon Committee and Oak Ridge National Laboratory.

$f_{\text {ORNL OPTAF measurements described in Sect. } 10.1 .}$

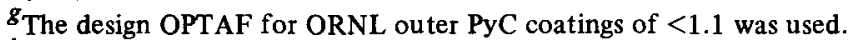

$h_{\mathrm{ND}}=$ not determined.

${ }^{i}$ OPTAF value for this batch was $>1.5$, and the maximum measurable OPTAF is 1.5 .

${ }^{j}$ The buffer and OPyC layers could not be separated from split samples sent for density determinations. The value shown was determined from a grab sample taken after coating.

the high-temperature, high-fluence regions, and 53 in the low-temperature, low-fluence regions. The two high-temperature regions each contained $0.265 \mathrm{~g}$ of thorium and $0.134 \mathrm{~g}$ of uranium. The two lowtemperature regions each contained $0.1875 \mathrm{~g}$ of thorium and $0.0955 \mathrm{~g}$ of uranium. The total weight per capsule of thorium was $0.905 \mathrm{~g}$, and per capsule of $7 \%$ enriched uranium was $0.459 \mathrm{~g}$. Each uranium holder and end cap contained $22.34 \mathrm{mg}$ of uranium in the high-temperature regions and $15.0 \mathrm{mg}$ in the low-temperature regions. 
Table 2.2. Loading scheme for capsules HT-12, -13, -14, and -15

\begin{tabular}{|c|c|c|c|c|c|}
\hline \multicolumn{2}{|c|}{ Sample holder } & \multirow{2}{*}{$\begin{array}{c}\text { Batch } \\
\text { number }\end{array}$} & \multirow[b]{2}{*}{ Design $^{a}$} & \multirow{2}{*}{$\begin{array}{c}\text { Case } \\
\text { number }\end{array}$} & \multirow{2}{*}{$\begin{array}{c}\text { Particle } \\
\text { type }\end{array}$} \\
\hline $\begin{array}{c}\text { Low } \\
\text { temperature }\end{array}$ & $\begin{array}{c}\text { High } \\
\text { temperature }\end{array}$ & & & & \\
\hline 1 & 14 & & & & $\mathrm{U}$ \\
\hline 2 & 15 & $4252-08$ & $499-39-119$ & 1 & $\mathrm{ThO}_{2}$ \\
\hline 3 & 16 & & & & $\mathrm{U}$ \\
\hline 4 & 17 & OR-1850 & $508-45-48$ & 2 & $\mathrm{ThO}_{2}$ \\
\hline 5 & 18 & OR-1846 & $400-20-21$ & 3 & $\mathrm{ThO}_{2}$ \\
\hline 6 & 19 & & & & $\mathbf{U}$ \\
\hline 7 & 20 & $4252-00$ & $405-81-76$ & 4 & $\mathrm{ThO}_{2}$ \\
\hline 8 & 21 & OR-1840 & $402-25-50$ & 5 & $\mathrm{ThO}_{2}$ \\
\hline 9 & 22 & & & & $\mathrm{U}$ \\
\hline 10 & 23 & $4252-06$ & $514-80-74$ & 6 & $\mathrm{ThO}_{2}$ \\
\hline 11 & 24 & OR-1749 & $402-33-36$ & 7 & $\mathrm{ThO}_{2}$ \\
\hline 12 & 25 & & & & $\mathrm{U}$ \\
\hline 13 & 26 & OR-1 849 & $508-79-75$ & 8 & $\mathrm{ThO}_{2}$ \\
\hline 40 & 27 & $4252-02$ & $508-83-75$ & 9 & $\mathrm{ThO}_{2}$ \\
\hline 41 & 28 & & & & $\mathrm{U}$ \\
\hline 42 & 29 & OR-1 1838 & $402-32-64$ & 10 & $\mathrm{ThO}_{2}$ \\
\hline 43 & 30 & $4252-03$ & $501-92-67$ & 11 & $\mathrm{ThO}_{2}$ \\
\hline 44 & 31 & & & & $\mathrm{U}$ \\
\hline 45 & 32 & OR-1826 & $402-21-31$ & 12 & $\mathrm{ThO}_{2}$ \\
\hline 46 & 33 & $4252-01$ & $487-61-76$ & 13 & $\mathrm{ThO}_{2}$ \\
\hline 47 & 34 & & & & $\mathrm{U}$ \\
\hline 48 & 35 & OR-1830 & $402-1-38$ & 14 & $\mathrm{ThO}_{2}$ \\
\hline 49 & 36 & $4252-07$ & $485-46-50$ & 15 & $\mathrm{ThO}_{2}$ \\
\hline 50 & 37 & & & & $\mathrm{U}$ \\
\hline 51 & 38 & OR-1837 & $402-1-24$ & 16 & $\mathrm{ThO}_{2}$ \\
\hline 52 & 39 & & & & $\mathrm{U}$ \\
\hline
\end{tabular}

${ }^{a}$ Design dimensions given as mean kernel diameter, mean buffer thickness, and mean PyC thickness.

\section{References}

1. Oak Ridge National Laboratory, Gulf General Atomic, and Allied Chemical Corporation, National HTGR Fuel Recycle Development Program Plan, ORNL-4702 (rev. 1, draft) (August 1973).

2. P. A. Haas, Sol-Gel Preparation of Spheres: Design and Operation of Fluidized Bed Columns, ORNL-4398 (September 1969). 


\section{IRRADIATION OF CAPSULES HT-12 THROUGH HT-15}

\subsection{Description of Facility}

The experimental capsules HT-12 through HT-15 were irradiated in the target facility of the HFIR. This facility is located in the center of the two concentric fuel annuli of the reactor core. Figure 3.1 describes the location of this region, which contains 30 target positions, three of which were used for the HT capsules and the remaining 27 for transuranium element production. Figure 3.2 describes the time variation of the thermal $(E<1.86 \mathrm{eV})$ and the fast (nonthermal) $(E>1.86 \mathrm{eV})$ group neutron fluxes ${ }^{1}$ during a typical HFIR cycle of 23 days. The nominal peak thermal flux at the reactor HMP for day 0 was $2.81 \times 10^{15}$ neutrons $\mathrm{cm}^{-2} \mathrm{sec}^{-1}$, and the nominal peak fast (nonthermal) flux was $3.09 \times 10^{15}$ neutrons $\mathrm{cm}^{-2} \mathrm{sec}^{-1}$. These fluxes remained relatively constant during the cycle, deviating somewhat less than $4 \%$ over the entire cycle at reactor full power of $100 \mathrm{MW}$. The axial variation of the neutron fluxes ${ }^{2}$ is shown in Fig. 3.3 as a function of distance from the HMP. At a distance of $0.25 \mathrm{~m}$ ( $10.0 \mathrm{in}$.) from the midplane,

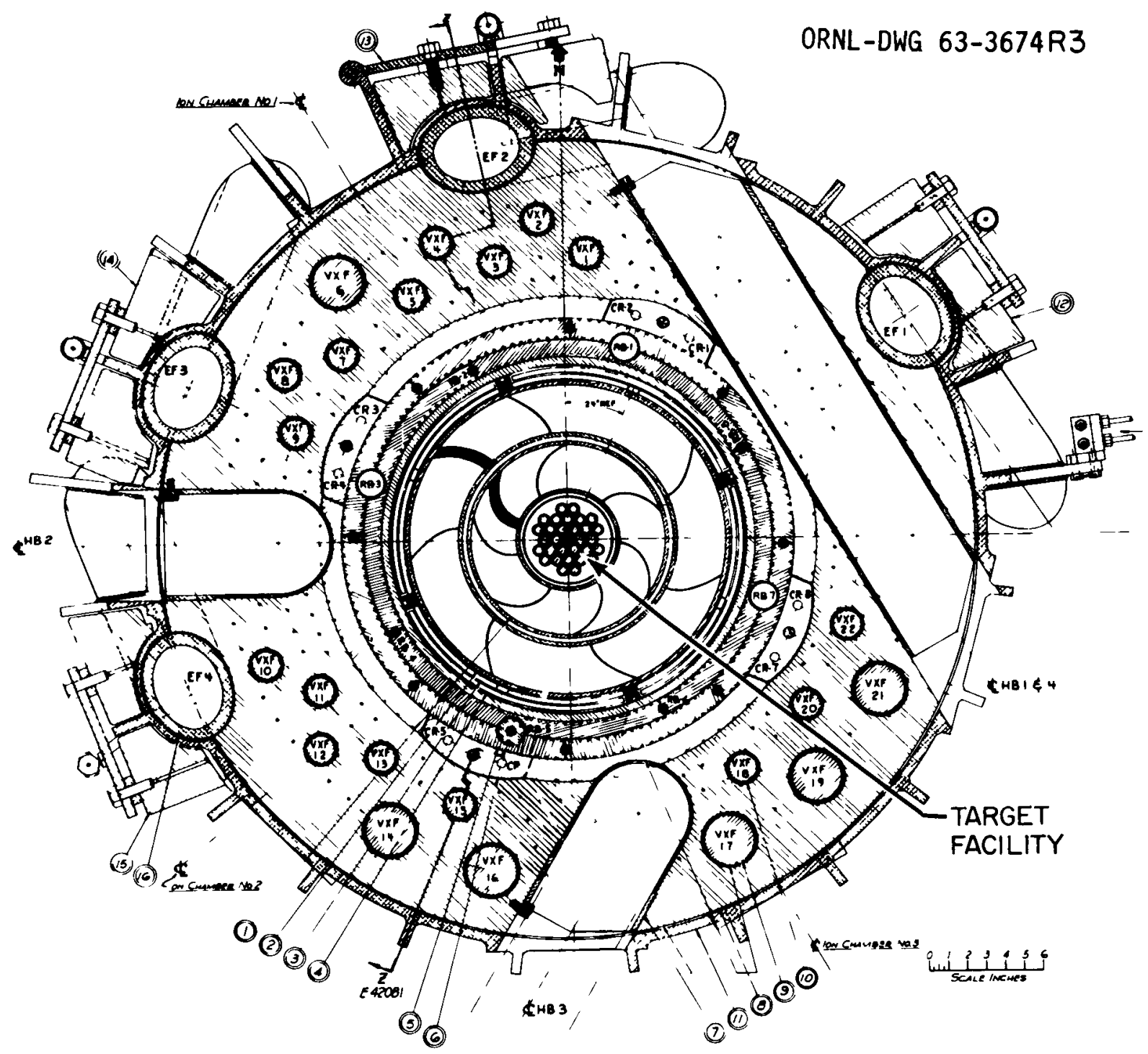

F1g. 3.1. HFIR cross section at horizontal midplane. 


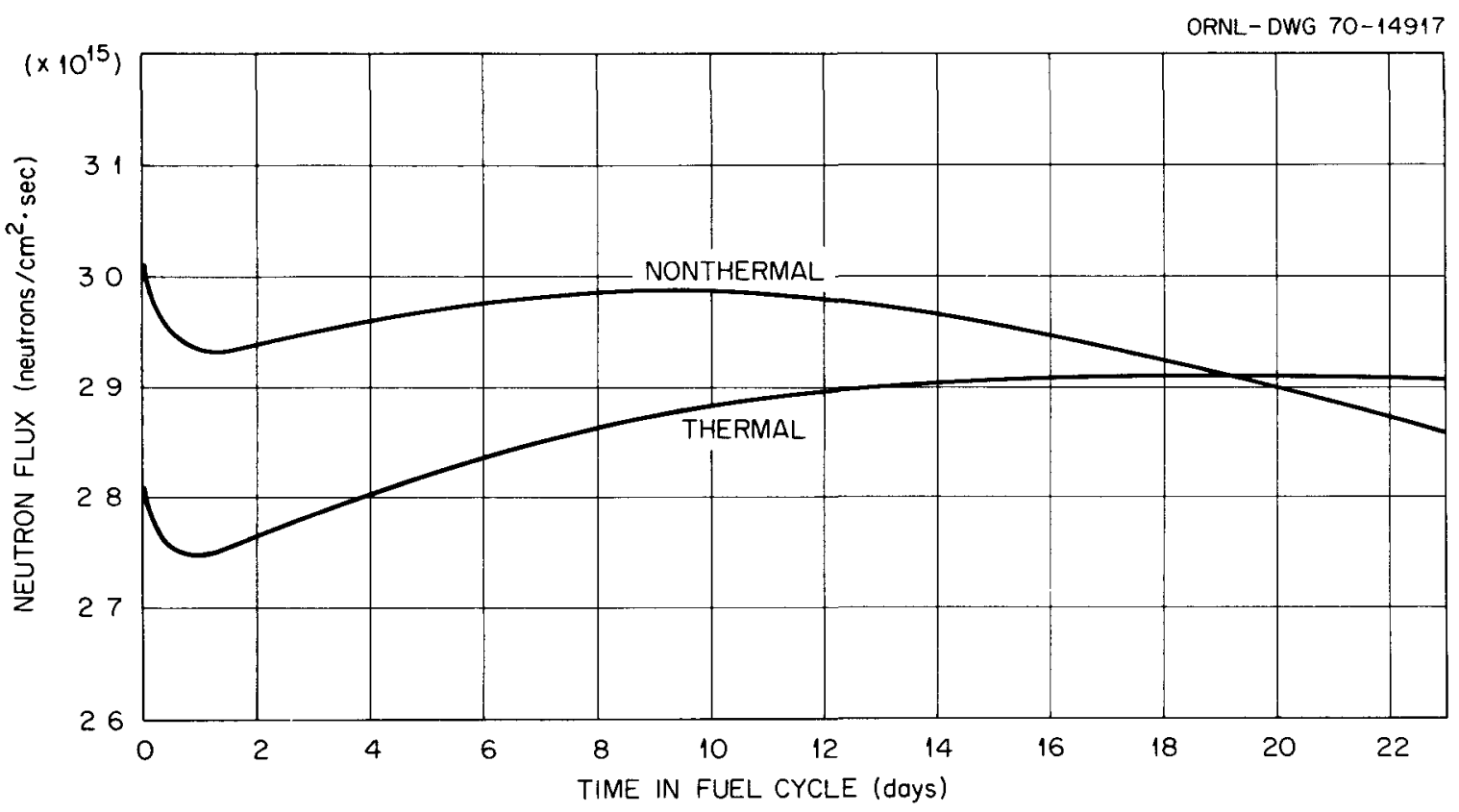

Fig 32 Nominal thermal and nonthermal fluxes applicable to the HMP of the target facility of the HFIR during one reactor cycle

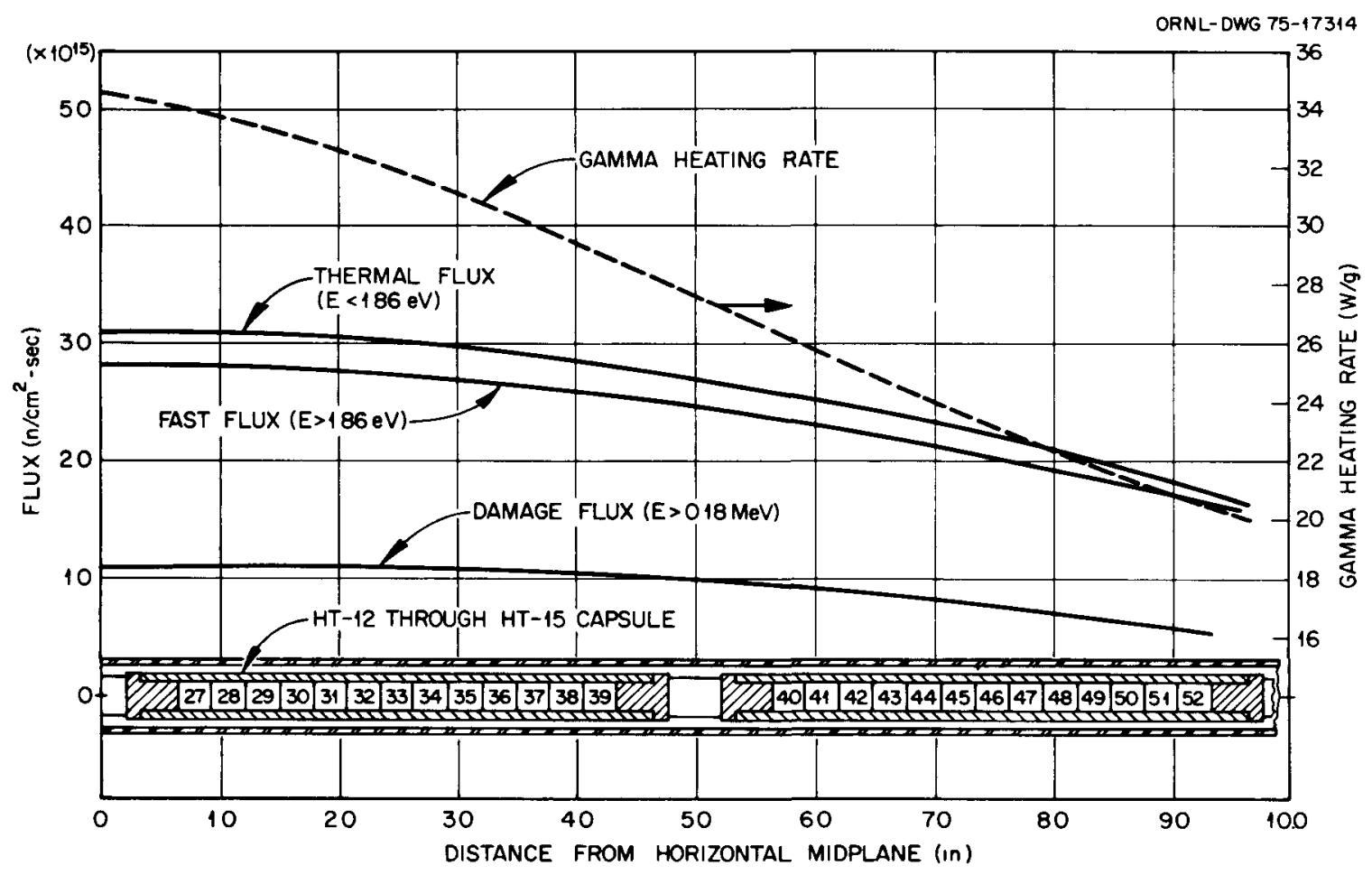

Fig 33 Nominal HFIR target neutron fluxes and gamma heating rate 
corresponding to the ends of the capsules, the flux values have decreased by a factor of 2 . Both the thermal and fast (nonthermal) fluxes are considered symmetric about the HMP.

Also shown in Fig. 3.3 are the axial variation in the fast neutron flux $(E>0.18 \mathrm{MeV})$ and the gamma heating rate as a function of distance from the reactor HMP. The peak value for the fast neutron flux $(E>0.18 \mathrm{MeV})$ at the midplane is $1.17 \times 10^{15}$ neutrons $\mathrm{cm}^{-2} \mathrm{sec}^{-1}$. Eighty percent of the heat generated within an HT capsule is due to gamma heating. ${ }^{3}$ The maximum and minimum values for the high-temperature sleeves are 33.5 and $29.4 \mathrm{~W} / \mathrm{g}$, respectively, and for the low-temperature sleeves 26.3 and $20.4 \mathrm{~W} / \mathrm{g}$ respectively.

\subsection{Operational History ${ }^{4}$}

Target capsule HT-12 was inserted in target position F-3 on September 10, 1972, and was removed on October 23, 1972, after 38.62 days at $100 \mathrm{MW}$ reactor power. The peak fast fluence was $3.9 \times 10^{21}$ neutrons $/ \mathrm{cm}^{2}(E>0.18 \mathrm{MeV})$, and peak fertile particle burnup was $1.92 \%$ FIMA.

Capsule HT-13 was inserted in target position G-6 on October 8, 1972, and was removed on January 10,1973 , after 85.58 days at $100 \mathrm{MW}$ reactor power. Peak fast fluence was $8.6 \times 10^{21}$ neutrons $/ \mathrm{cm}^{2}(E>0.18 \mathrm{MeV})$, and peak fertile particle burnup was $8.43 \%$ FIMA.

Capsule HT-14 was inserted in target position F-3 on November 20, 1972, and was removed on April 15, 1973, after 137.00 days at $100 \mathrm{MW}$ reactor power. The peak fast fluence was $1.4 \times 10^{22}$ neutrons $/ \mathrm{cm}^{2}(E>0.18 \mathrm{MeV})$, and the established peak fertile particle burnup was $16.6 \%$ FIMA.

Table 3.1. Irradiation history

\begin{tabular}{|c|c|c|c|c|c|c|c|c|}
\hline \multirow{3}{*}{$\begin{array}{l}\text { HFIR } \\
\text { cycle }\end{array}$} & \multirow{3}{*}{ Begin } & \multirow{3}{*}{ End } & \multirow{3}{*}{$\begin{array}{c}\text { Time } \\
\text { interval } \\
\text { (days) }\end{array}$} & \multirow{3}{*}{$\begin{array}{l}\text { Power } \\
\text { (MW) }\end{array}$} & \multicolumn{4}{|c|}{$\begin{array}{l}\text { Accumulated irradiation } \\
\text { (100-MW power days) }\end{array}$} \\
\hline & & & & & \multicolumn{4}{|c|}{ Capsule } \\
\hline & & & & & HT-12 & $\mathrm{HT}-13$ & HT-14 & HT-15 \\
\hline 82 & $9-10-72$ & $10-3-72$ & 2344 & 100 & 23.44 & & & \\
\hline Down & & & 5.00 & 0 & & & & \\
\hline 83 & $10-8-72$ & $10-23-72$ & 15.18 & 100 & 38.62 & 15.18 & & \\
\hline Down & & & 100 & 0 & & & & \\
\hline $84 a$ & $10-24-72$ & $11-11-72$ & 18.00 & 100 & & 33.18 & & \\
\hline Down & & & 2.00 & 0 & & & & \\
\hline $84 b$ & $11-13-72$ & $11-19-72$ & 5.37 & 100 & & 38.55 & & \\
\hline Down & & & 1.00 & 0 & & & & \\
\hline 85 & $11-20-72$ & $12-13-72$ & 23.09 & 100 & & 61.64 & 23.09 & 23.09 \\
\hline Down & & & 0.50 & 0 & & & & \\
\hline 86 & $12-13-72$ & $12-22-72$ & 8.51 & 100 & & 70.64 & 32.09 & 32.09 \\
\hline 86 & $12-22-72$ & $12-23-72$ & 1.00 & 83 & & 71.47 & 32.92 & 32.92 \\
\hline 86 & $12-23-72$ & $12-25-72$ & 2.00 & 50 & & 72.47 & 33.92 & 33.92 \\
\hline 86 & $12-25-72$ & $1-7-73$ & 13.00 & 100 & & 84.98 & 46.35 & 46.35 \\
\hline Down & & & 2.00 & 0 & & & & \\
\hline $87 \mathrm{a}$ & $1-9-73$ & $1-10-73$ & 0.60 & 100 & & 85.58 & 46.95 & 46.95 \\
\hline Down & & & 2.10 & 0 & & & & \\
\hline $87 b$ & $1-12-73$ & $2-3-73$ & 21.75 & 100 & & & 68.70 & 68.70 \\
\hline Down & & & 0.40 & 0 & & & & \\
\hline 88 & $2-3-73$ & $2-26-73$ & 22.71 & 100 & & & 91.41 & 91.41 \\
\hline Down & & & 1.00 & 0 & & & & \\
\hline 89 & $2-27-73$ & $3-22-73$ & 22.73 & 100 & & & 114.14 & 114.14 \\
\hline Down & & & 1.00 & 0 & & & & \\
\hline 90 & $3-23-73$ & $4-15-73$ & 22.86 & 100 & & & 137.00 & 137.00 \\
\hline Down & & & 3.00 & 0 & & & & \\
\hline 91 & $4-18-73$ & $5-11-73$ & 22.96 & 100 & & & & 159.96 \\
\hline
\end{tabular}


Capsule HT-15 was inserted in target position A-2 on November 20, 1972, and was removed on May 11, 1973, after 159.96 days at $100 \mathrm{MW}$ reactor power. The peak fast fluence was $1.6 \times 10^{22}$ neutrons $/ \mathrm{cm}^{2}(E>018 \mathrm{MeV})$, and the estımated peak fertıle particle burnup was $20.3 \%$ FIMA.

Table 31 describes the operation history of the reactor during the irradiation of each capsule Table 32 summarizes the thermal and fast neutron fluxes, fast neutron fluence $(E>0.18 \mathrm{MeV})$, and the estımated fertıle partıcle burnup for each sample holder in each capsule. No attempt has been made to estımate the fissile particle burnup.

Table 3.2. Irradiation summary for capsules HT-12 through HT-15

\begin{tabular}{|c|c|c|c|c|c|c|c|c|c|c|c|}
\hline \multirow{2}{*}{\multicolumn{2}{|c|}{$\begin{array}{l}\text { Sample } \\
\text { holder }\end{array}$}} & \multirow{2}{*}{$\begin{array}{c}\text { Distance } \\
\text { from specimen } \\
\text { holder to } \\
\mathrm{HMP}^{a} \text { (1n) }\end{array}$} & \multirow[t]{2}{*}{$\begin{array}{c}\text { Thermal }^{b} \\
\text { flux }\end{array}$} & \multirow[t]{2}{*}{$\begin{array}{l}\text { Fast }^{c} \\
\text { flux }\end{array}$} & \multirow[t]{2}{*}{$\begin{array}{c}\text { Fast }^{d} \\
\text { flux }\end{array}$} & \multicolumn{2}{|c|}{$\begin{array}{c}\text { Ratio, } \\
\text { fast/thermal }\end{array}$} & \multicolumn{4}{|c|}{$\begin{array}{c}\text { Fast neutron fluence } \\
(E>018 \mathrm{MeV}, \\
\left.\text { neutrons } / \mathrm{cm}^{2} \times 10^{21}\right)\end{array}$} \\
\hline & & & & & & $c / b$ & $d / b$ & HT-12 & HT-13 & HT-14 & HT-15 \\
\hline \multicolumn{12}{|c|}{ Low Temperature } \\
\hline 2 & 51 & 8909 & 175 & 141 & 059 & 081 & 042 & 20 & 43 & 69 & 81 \\
\hline 4 & 49 & 8344 & 187 & 157 & 067 & 084 & 043 & 22 & 49 & 79 & 93 \\
\hline 5 & 48 & 8061 & 193 & 167 & 070 & 087 & 042 & 23 & 52 & 83 & 97 \\
\hline 7 & 46 & 7496 & 205 & 185 & 076 & 090 & 041 & 25 & 56 & 90 & 105 \\
\hline 8 & 45 & 7214 & 211 & 192 & 080 & 091 & 042 & 26 & 58 & 94 & 110 \\
\hline 10 & 43 & 6649 & 224 & 208 & 085 & 093 & 041 & 28 & 62 & 100 & 117 \\
\hline 11 & 42 & 6366 & 231 & 216 & 088 & 094 & 041 & 29 & 65 & 104 & 12.2 \\
\hline 13 & 40 & 5801 & 242 & 230 & 093 & 095 & 040 & 30 & 67 & 110 & 12.8 \\
\hline \multicolumn{12}{|c|}{ High Temperature } \\
\hline 15 & 38 & 3909 & 283 & 270 & 106 & 095 & 039 & 35 & 78 & 125 & 146 \\
\hline 17 & 36 & 3344 & 294 & 280 & 109 & 095 & 039 & 36 & 81 & 129 & 15.1 \\
\hline 18 & 35 & 3061 & 300 & 283 & 111 & 0.94 & 039 & 37 & 82 & 131 & 15.3 \\
\hline 20 & 33 & 2496 & 310 & 291 & 113 & 094 & 039 & 38 & 83 & 134 & 156 \\
\hline 21 & 32 & 2214 & 313 & 294 & 114 & 094 & 039 & 38 & 84 & 135 & 157 \\
\hline 23 & 30 & 1649 & 319 & 300 & 116 & 094 & 039 & 39 & 85 & 137 & 16.0 \\
\hline 24 & 29 & 1366 & 322 & 303 & 116 & 094 & 038 & 39 & 86 & 138 & 161 \\
\hline 26 & 27 & 0801 & 325 & 311 & 117 & 096 & 038 & 39 & 86 & 139 & 162 \\
\hline
\end{tabular}

\footnotetext{
${ }^{a}$ HMP $=$ horizontal midplane

${ }^{b}$ Neutrons $\mathrm{cm}^{-2} \mathrm{sec}^{-1}\left(E<186 \mathrm{eV} \times 10^{-15}\right)$

${ }^{c}$ Neutrons $\mathrm{cm}^{-2} \mathrm{sec}^{-1}\left(E>186 \mathrm{eV} \times 10^{-15}\right)$

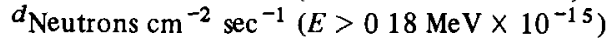

\section{References}

1. R. D. Cheverton and T. M. Sims, HFIR Core Nuclear Design, ORNL-4621, p. 26 (July 1971)

2. Unpublished work of J. D. Jenkıns.

3. Personal communication, P. H. Montgomery to M. J. Kania, August 1974.

4. B. H. Montgomery, "Irradiation Tests in the HFIR Target Facility," Gas-Cooled Reactor Programs Ann. Prog. Rep. Dec. 31, 1973, ORNL-4975, pp. 128-30. 


\section{CAPSULE DISASSEMBLY}

\subsection{Visual Inspection ${ }^{1,2}$}

Each of the capsules was opened by cutting off the ends of the aluminum containment tube. In capsules HT-12 and -13, the high- and low-temperature magazines were easily removed. In capsule HT14 , some difficulties were encountered in removing the high-temperature magazines because of the swelling of the Poco graphite. In capsule HT-15 the swelling of the Poco graphite magazine had completely closed the initial gap between it and the containment tube. Magazines were removed only after slitting the aluminum containment.

Individual particle sample holders were then pushed out of the graphite magazines into a tray, and the contents of each were visually inspected. Some difficulties were experienced in retrieving the samples in the high-temperature holders in HT-13, -14 , and -15 because of the degradation and swelling of the Poco graphite (sample holders). The results of the visual inspection and the stereoscopic examination of particles in each sample holder for each capsule are described below.

\section{HT-12}

Capsule HT-12 was observed to be free of the sooty material previously found in most target capsules. This was attributed to the gettering action of the zirconium foil disks placed between the specimen holders in the magazines; however, some sticking of the specimen holders to each other was observed. No evidence of pitting or corrosion on the graphite magazine was observed.

ORNL particles. No failures were observed for particles irradiated in the low-temperature sample holders as determined by visual inspection. In the high-temperature sample holders, one particle batch, OR-1837, experienced a $55 \%$ failure rate ( 41 out of 75 ).

GAC particles. In the low-temperature holders, one particle batch, GGA 4252-06, experienced a $2 \%$ failure rate ( 1 out of 53 ). Of the samples irradiated in the high-temperature holders, only two performed without any observed failures, batches GGA 4252-06 and GGA 4252-02. All of the other five samples experienced a high fraction of failed coatings. All GAC samples were shipped to San Diego for further examination and evaluation. ${ }^{3}$

\section{HT-13}

The capsules and magazines were observed to be free of soot as in the previous capsule. However, an important observation from this examination was the degradation and swelling of the Poco graphite sample holders irradiated in the high-temperature regions. Even though there was no evidence of oxidation or mass transport in the sealed capsule, the graphite was so weak and friable that the sample holder screw caps could not be removed without drilling out the threads.

ORNL particles. In the low-temperature sample holders, all samples except batch OR-1749 survived. This sample had an intermediate coating design and experienced a $13 \%$ failure rate ( 7 out of 53). In the high-temperature holders, four samples with thin coatings-batches OR-1846, -1826, -1830, and -1837-showed complete or a high incidence of failure, whereas similiar samples with conservatively designed coatings survived. One sample (proposed reference), batch OR-1849, with a $500-\mu \mathrm{m}$-diam kernel survived completely, whereas a similar sample, OR-1850, with a thinner coating failed almost completely.

GAC particles. In the low-temperature holders, only two samples, batches GGA $4252-06$ and GGA 4252-02, survived completely, whereas all the others showed a significantly high rate of failure. In the 
high-temperature holders, all samples showed complete or high rate of failure. All GAC samples were shipped to San Diego for further examination and evaluation. ${ }^{3}$

HT-14

The capsules and magazines were relatively free of soot and did not show any evidence of corrosion. The two low-temperature magazines were unloaded without difficulty, and the samples of coated particles were easily removed. However, the two magazines and associated graphite sample holders in the high-temperature regions exhibited extreme swelling.

ORNL particles. In the low-temperature holders, samples from batch OR-1846 had a $2 \%$ failure rate ( 1 out of 53), batches OR-1 850 and OR-1749 each had a 4\% failure rate ( 2 out of 53), and batch OR1826 had a $19 \%$ failure rate (10 out of 53). The remaining samples performed without any observed failures. In the high-temperature holders, all but three samples failed completely or had high failure rates. Batches OR-1840 and OR-1849 survived completely, and batch OR-1838 had a 3\% failure rate (2 out of 75).

GAC particles. All the samples except two, batches GGA 4252-06 and GGA 4252-02, showed a complete or high rate of failure in the low-temperature holders. All of the samples in the hightemperature holders failed completely or showed a high rate of failure. All of GAC's samples were shipped to San Diego for further inspection and evaluation. ${ }^{3}$

HT-15

Capsule HT-15 was withdrawn after a seven-cycle irradiation because of the extreme swelling of the Poco graphite holders and magazines observed in HT-14.

ORNL particles. In the low-temperature holders, four samples had survived completely. For the remaining samples, failure rates were: $4 \%$ for batch OR-1830 ( 2 out of 53), $6 \%$ for batch OR-1850 ( 3 out of 53); $9 \%$ for batch OR-1837 ( 5 out of 53), 13\% for batch OR-1749 (7 out of 53), and $21 \%$ for batch OR1826 (11 out of 53). In the high-temperature holders, two samples survived completely, batches OR-1749 and OR-1838. The proposed reference design, batch OR-1849, had a $3 \%$ failure rate ( 2 out of 75 ). The remaining samples showed a complete or high rate of failure.

GAC particles. One sample, GGA 4252-06, survived completely, whereas all others showed a complete or high rate of failure in the low-temperature holders. All of the samples in the hightemperature holders exhibited complete failure. All GAC samples were shipped to San Diego for further examination and evaluation of results. ${ }^{3}$

Table 4.1 summarizes the results from the visual inspection of the samples irradiated in capsules HT-12 through HT-15.

\subsection{Graphite Dimensional Changes}

As noted earlier, diametrical expansion of the Poco graphite magazines was severe in the hightemperature regions of capsules HT-14 and -15. In HT-14, the extreme swelling nearly closed the gap between the magazine and the aluminum containment tube. For this reason, capsule HT-15 was withdrawn from the reactor one cycle ahead of schedule. Examination of capsule HT-15 showed that the extreme swelling of the graphite magazines in the high-temperature regions had completely closed the initial gap between it and the aluminum tube. Based on design dimensions, the diametrical expansion of the high-temperature magazines in capsule HT-15 was more than $6 \%$. Table 4.2 describes the graphite dimensional changes observed for the high- and low-temperature magazines of capsules HT-14 and -15. 
Table 4.1. Survival rates ${ }^{a}$ by visual inspection for Biso-coated $\mathrm{ThO}_{2}$ particles in capsules HT-12 through HT-15

\begin{tabular}{|c|c|c|c|c|c|}
\hline $\begin{array}{c}\text { Holder } \\
\text { no. }\end{array}$ & Sample & HT-12 & HT-13 & HT-14 & HT-15 \\
\hline \multicolumn{6}{|c|}{ Low-temperature holders } \\
\hline 2 & GGA 4252-08 & 100 & 0 & 2 & $b$ \\
\hline 4 & ORNL OR-1850 & 100 & 100 & 96 & 94 \\
\hline 5 & ORNL OR-1846 & 100 & 100 & 98 & 100 \\
\hline 7 & GGA 4252-00 & 100 & 92 & 2 & 13 \\
\hline 8 & ORNL OR-1840 & 100 & 100 & 100 & 100 \\
\hline 10 & GGA 4252-06 & 98 & 100 & 100 & 100 \\
\hline 11 & ORNL OR-1749 & 100 & 87 & 96 & 87 \\
\hline 13 & ORNL OR-1849 & 100 & 100 & 100 & 100 \\
\hline 40 & GGA 4252-02 & 100 & 100 & 100 & 55 \\
\hline 42 & ORNL OR-1838 & 100 & 100 & 100 & 100 \\
\hline 43 & GGA 4252-03 & 100 & 0 & 0 & 0 \\
\hline 45 & ORNL OR-1826 & 100 & 100 & 81 & 79 \\
\hline 46 & GGA 4252-01 & 100 & 68 & 0 & 0 \\
\hline 48 & ORNL OR-1830 & 100 & 100 & 100 & 96 \\
\hline 49 & GGA 4252-07 & 100 & 62 & 0 & 0 \\
\hline 51 & ORNL OR-1837 & 100 & 100 & 100 & 91 \\
\hline \multicolumn{6}{|c|}{ High-temperature holders } \\
\hline 15 & GGA 4252-08 & 40 & 0 & 0 & 0 \\
\hline 17 & ORNL OR-1850 & 100 & 3 & 0 & 0 \\
\hline 18 & ORNL OR-1846 & 100 & 0 & 0 & 0 \\
\hline 20 & GGA 4252-00 & 97 & 0 & 0 & 0 \\
\hline 21 & ORNL OR-1840 & 100 & 100 & 100 & 7 \\
\hline 23 & GGA 4252-06 & 100 & 0 & 15 & 19 \\
\hline 24 & ORNL OR-1749 & 100 & 100 & 7 & 100 \\
\hline 26 & ORNL OR-1849 & 100 & 100 & 100 & 97 \\
\hline 27 & GGA 4252-02 & 100 & 12 & 11 & 0 \\
\hline 29 & ORNL OR-1838 & 100 & 100 & 97 & 100 \\
\hline 30 & GGA 4252-03 & 0 & 0 & 0 & 0 \\
\hline 32 & ORNL OR-1826 & 100 & 23 & 11 & 44 \\
\hline 33 & GGA 4252-01 & 73 & 0 & 0 & 0 \\
\hline 35 & ORNL OR-1830 & 100 & 0 & 0 & 0 \\
\hline 36 & GGA 4252-07 & 75 & 0 & 0 & 0 \\
\hline 38 & ORNL OR-1837 & 45 & 0 & 0 & 0 \\
\hline
\end{tabular}

${ }^{a}$ All values reported as percent survived.

${ }^{b}$ Sample holder 2 was shipped to San Diego unopened

The Poco graphite sample holders located in the high-fluence, high-temperature magazines of capsules HT-13, -14, and -15 also experienced extreme swelling and degradation of the graphite. Based on the design dimensions, the diametrical changes ranged from $<1 \%$ in the low-fluence, low-temperature holders to $>7 \%$ for the high-fluence, high-temperature holders in HT-14, and $>9 \%$ for holders in HT- 15 . Table 4.3 summarizes the dimensional changes for particle holders in capsules HT-14 and -15 .

In addition to the swelling and degradation, the sample holders in the high-fluence, hightemperature regions of HT-15 were severely distorted. Many had an "hourglass" appearance, having expanded about $4 \%$ in the midsection and at least $8 \%$ at the ends. Figure 4.1 shows the appearance of an as-fabricated sample holder and the appearance after irradiation of sample holder No. 25 in magazine CP-61 and sample holder No. 36 in magazine CP-62. 
Table 4.2. Dimensional changes for the high- and low-temperature graphite magazines for HT-14 and -15

\begin{tabular}{|c|c|c|c|c|c|}
\hline \multirow{2}{*}{$\begin{array}{c}\text { Magazine } \\
\text { No. }\end{array}$} & \multicolumn{3}{|c|}{ Outside diameter (in.) } & \multirow{2}{*}{$\begin{array}{l}\text { Inside } \\
\text { diameter } \\
\text { (in.) }\end{array}$} & \multirow{2}{*}{$\begin{array}{l}\text { Length } \\
\text { (in.) }\end{array}$} \\
\hline & $\begin{array}{c}\text { Large } \\
\left(0^{\circ} / 90^{\circ}\right)\end{array}$ & $\begin{array}{l}\text { Midpoint } \\
\left(0^{\circ} / 90^{\circ}\right)\end{array}$ & $\begin{array}{c}\text { Small } \\
\left(0^{\circ} / 90^{\circ}\right)\end{array}$ & & \\
\hline \multicolumn{6}{|c|}{ Preirradiation $^{a}$} \\
\hline $\begin{array}{l}\text { CP-56,-59, } \\
-60,-63\end{array}$ & $0.5139 / 0.5129$ & $b$ & $0.5011 / 0.5001$ & $0.388 / 0.386$ & $4.311 / 4.309$ \\
\hline $\begin{array}{l}\text { CP-57,-58, } \\
-61,-62\end{array}$ & $0.4965 / 0.4955$ & $b$ & $0.4765 / 0.4755$ & $0.388 / 0.386$ & $4.311 / 4.309$ \\
\hline \multicolumn{6}{|c|}{ Postirradiation } \\
\hline CP-56 & $0.5165 / 0.5165$ & $0.5134 / 0.5120$ & $0.5060 / 0.5055$ & $b$ & $b$ \\
\hline CP-57 & $b$ & $b$ & $b$ & $b$ & $b$ \\
\hline CP-58 & $b$ & $b$ & $b$ & $b$ & $b$ \\
\hline CP-59 & $0.5175 / 0.5173$ & $0.5130 / 0.5140$ & $0.5060 / 0.5055$ & $b$ & $b$ \\
\hline $\mathrm{CP}-60$ & $0.5186 / 0.5200$ & $0.5130 / 0.5135$ & $0.5088 / 0.5100$ & $b$ & $b$ \\
\hline $\mathrm{CP}-61$ & $0.5330 / 0.5323$ & $0.5230 / 0.5234$ & $0.5024 / 0.5065$ & $b$ & $b$ \\
\hline CP-62 & $0.5222 / 0.5270$ & $0.5215 / 0.5253$ & $0.5022 / 0.5010$ & $b$ & $b$ \\
\hline CP-63 & $0.5160 / 0.5162$ & $0.5086 / 0.5077$ & $0.5073 / 0.5068$ & $b$ & $b$ \\
\hline
\end{tabular}

${ }^{a}$ Preirradiation dimensions are the same as design.

${ }^{b}$ Dimensions were not measured.

$Y 136492$

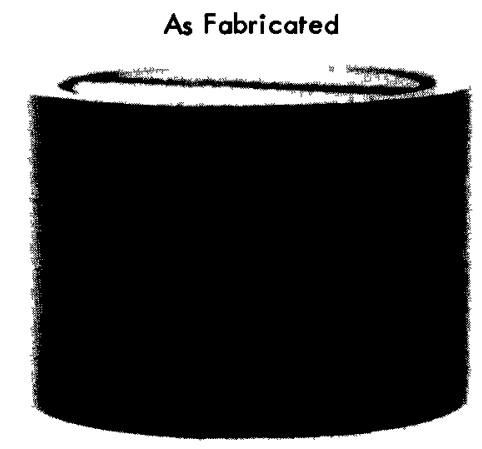

$16.1 \times 10^{21} \mathrm{n} / \mathrm{cm}^{2}$

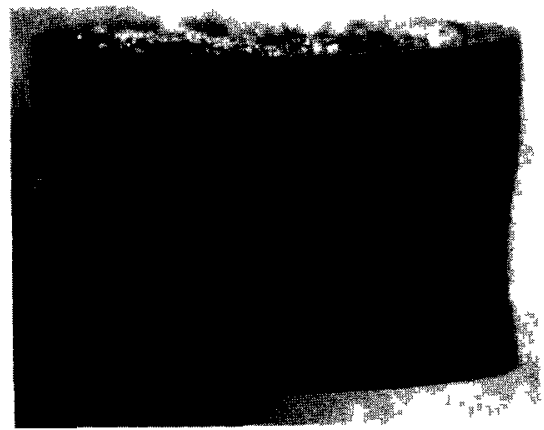

Uranium Fueled

Holder No. 25

(CP-61)

Irradiated

$15.1 \times 10^{21} \mathrm{n} / \mathrm{cm}^{2}$

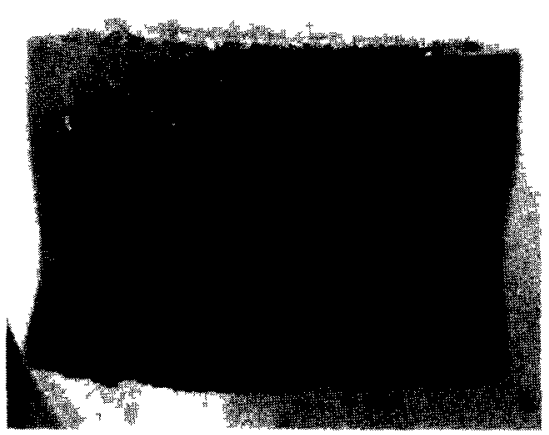

Thorium Fueled

Holder No. 36

(CP-62)

Fig. 4.1. Coated particle holders for loose particles irradiated in high-temperature $\left(1500-1600^{\circ} \mathrm{C}\right)$ magazines in HT-15. 
Table 4.3. Dimensional changes for particle holders in HT-14 and HT-15

\begin{tabular}{|c|c|c|c|c|c|c|c|c|c|}
\hline \multirow{2}{*}{$\begin{array}{l}\text { Holder } \\
\text { No. }\end{array}$} & \multirow{2}{*}{$\begin{array}{l}\text { Type of } \\
\text { particle }\end{array}$} & \multicolumn{4}{|c|}{ HT-14 } & \multicolumn{4}{|c|}{ HT-15 } \\
\hline & & $\begin{array}{l}\text { Length } \\
\text { (in.) }\end{array}$ & $\begin{array}{l}\text { Percent } \\
\text { change }\end{array}$ & $\begin{array}{l}\text { Diameter } \\
\text { (in.) }\end{array}$ & $\begin{array}{l}\text { Percent } \\
\text { change }\end{array}$ & $\begin{array}{l}\text { Length } \\
\text { (in.) }\end{array}$ & $\begin{array}{l}\text { Percent } \\
\text { change }\end{array}$ & $\begin{array}{l}\text { Diameter } \\
\text { (in.) }\end{array}$ & $\begin{array}{l}\text { Percent } \\
\text { change }\end{array}$ \\
\hline \multicolumn{10}{|c|}{ Preirradiation } \\
\hline & & $0.275 / 0.274$ & & $0.3855 / 0.384$ & & $0.275 / 0.274$ & & $0.3855 / 0.3845$ & \\
\hline \multicolumn{10}{|c|}{ Postirradiation } \\
\hline 1 & $\mathrm{U}$ & 0.2775 & 1.09 & 0.3900 & 1.30 & 0.2748 & 0.11 & 0.3885 & 0.91 \\
\hline 2 & $\mathrm{ThO}_{2}$ & & & & & 0.2732 & -0.47 & 0.3887 & 0.96 \\
\hline 3 & $\mathrm{U}$ & 0.2775 & 1.09 & 0.3884 & 0.88 & 0.2759 & 0.51 & 0.3888 & 0.99 \\
\hline 4 & $\mathrm{ThO}_{2}$ & & & & & 0.2788 & 1.57 & 0.3885 & 0.91 \\
\hline 5 & $\mathrm{ThO}_{2}$ & & & & & 0.2767 & 0.80 & 0.3876 & 0.68 \\
\hline 6 & $\mathbf{U}$ & 0.2750 & 0.18 & 0.3880 & 0.78 & 0.2745 & 0.00 & 0.3868 & 0.47 \\
\hline 7 & $\mathrm{ThO}_{2}$ & & & & & 0.2750 & 0.18 & 0.3905 & 1.43 \\
\hline 8 & $\mathrm{ThO}_{2}$ & & & & & 0.2750 & 0.18 & 0.3893 & 1.12 \\
\hline 9 & $\mathrm{U}$ & 0.2778 & 1.20 & 0.3885 & 0.91 & 0.2768 & 0.84 & 0.3889 & 1.01 \\
\hline 10 & $\mathrm{ThO}_{2}$ & & & & & 0.2775 & 1.09 & 0.3895 & 1.17 \\
\hline 11 & $\mathrm{ThO}_{2}$ & & & & & 0.2782 & 1.35 & 0.3910 & 1.56 \\
\hline 12 & $U$ & 0.2790 & 1.64 & 0.3890 & 1.04 & 0.2842 & 3.53 & 0.3910 & 1.56 \\
\hline 13 & $\mathrm{ThO}_{2}$ & & & & & 0.2761 & 0.58 & 0.3899 & 1.27 \\
\hline 14 & $\mathrm{U}$ & & & & & 0.2937 & 6.99 & 0.4110 & 6.75 \\
\hline 15 & $\mathrm{ThO}_{2}$ & 0.2882 & 4.99 & 0.4038 & 4.88 & 0.3015 & 9.84 & 0.4170 & 8.31 \\
\hline 16 & $\mathrm{U}$ & & & & & 0.3042 & 10.82 & 0.4180 & 8.57 \\
\hline 17 & $\mathrm{ThO}_{2}$ & 0.310 & 12.93 & 0.414 & 7.53 & 0.3150 & 14.75 & 0.4230 & 9.87 \\
\hline 18 & $\mathrm{ThO}_{2}$ & & & 0.412 & 7.01 & 0.2951 & 7.50 & 0.4216 & 9.51 \\
\hline 19 & $\mathrm{U}$ & & & & & 0.2910 & 6.01 & 0.4153 & 7.88 \\
\hline 20 & $\mathrm{ThO}_{2}$ & 0.2965 & 8.01 & 0.4100 & 6.49 & 0.2910 & 6.01 & 0.4183 & 8.65 \\
\hline 21 & $\mathrm{ThO}_{2}$ & 0.301 & 9.65 & 0.411 & 6.75 & 0.2990 & 8.93 & 0.4197 & 9.01 \\
\hline 22 & $\mathrm{U}$ & & & & & 0.2865 & 4.37 & 0.4178 & 8.52 \\
\hline 23 & $\mathrm{ThO}_{2}$ & 0.2960 & 7.83 & 0.4112 & 6.81 & 0.2928 & 6.67 & 0.4190 & 8.83 \\
\hline 24 & $\mathrm{ThO}_{2}$ & 0.296 & 7.83 & 0.410 & 6.49 & 0.2958 & 7.76 & 0.4180 & 8.57 \\
\hline 25 & $\mathrm{U}$ & & & & & 0.2985 & 8.74 & 0.4170 & 8.31 \\
\hline 26 & $\mathrm{ThO}_{2}$ & 0.298 & 8.56 & 0.412 & 7.01 & 0.2964 & 7.98 & 0.4187 & 8.75 \\
\hline 27 & $\mathrm{ThO}_{2}$ & 0.291 & 6.01 & 0.406 & 5.45 & 0.2990 & 8.93 & 0.4195 & 8.96 \\
\hline 28 & $\mathrm{U}$ & & & & & 0.3015 & 9.84 & 0.4177 & 8.49 \\
\hline 29 & $\mathrm{ThO}_{2}$ & 0.292 & 6.38 & 0.409 & 6.23 & 0.2932 & 6.81 & 0.4178 & 8.52 \\
\hline 30 & $\mathrm{ThO}_{2}$ & 0.2895 & 5.46 & 0.4063 & 5.53 & 0.2947 & 7.36 & 0.4168 & 8.26 \\
\hline 31 & $\mathrm{U}$ & & & & & 0.2975 & 8.38 & 0.4135 & 7.40 \\
\hline 32 & $\mathrm{ThO}_{2}$ & 0.288 & 4.92 & 0.407 & 5.71 & 0.2948 & 7.40 & 0.4185 & 8.70 \\
\hline 33 & $\mathrm{ThO}_{2}$ & 0.2860 & 4.19 & 0.4033 & 4.75 & 0.3028 & 10.31 & 0.4180 & 8.57 \\
\hline 34 & $\mathrm{U}$ & & & & & 0.2992 & 9.00 & 0.4210 & 9.35 \\
\hline 35 & $\mathrm{ThO}_{2}$ & 0.2875 & 4.74 & 0.4018 & 4.36 & 0.2973 & 8.31 & 0.4230 & 9.87 \\
\hline 36 & $\mathrm{ThO}_{2}$ & 0.2955 & 7.65 & 0.4030 & 4.68 & 0.298 & 8.56 & 0.4225 & 9.74 \\
\hline 37 & $\mathrm{U}$ & & & & & 0.3002 & 9.36 & 0.4180 & 8.57 \\
\hline 38 & $\mathrm{ThO}_{2}$ & 0.2930 & 6.74 & 0.3990 & 3.64 & 0.3055 & 11.29 & 0.4207 & 9.27 \\
\hline 39 & $\mathrm{U}$ & & & & & 0.2938 & 7.03 & 0.4164 & 8.16 \\
\hline 41 & $\mathrm{U}$ & 0.2775 & 1.09 & 0.3880 & 0.78 & & & & \\
\hline 44 & $\mathbf{U}$ & 0.2775 & 1.09 & 0.3880 & 0.78 & & & & \\
\hline 47 & $\mathbf{U}$ & 0.2770 & 0.91 & 0.3885 & 0.91 & & & & \\
\hline 50 & $\mathrm{U}$ & 0.2768 & 0.84 & 0.3880 & 0.78 & & & & \\
\hline 52 & $\mathrm{U}$ & 0.2785 & 1.46 & 0.3990 & 3.64 & & & & \\
\hline
\end{tabular}




\section{References}

1. J. H. Coobs et al., "Irradiation Stability of Carbon Coatings on HTGR Fuel Particles," p. 249 in 11th Biennial Conference on Carbon, June 4-8, 1973, CONF-730601, Sponsored by the American Carbon Committee and Oak Ridge National Laboratory.

2. J. H. Coobs, W. P. Eatherly, and J. L. Scott, "Testing and Irradiation Performance of Coated Particle Fuels for HTGR's," pp. 38.1-38.4 in International Conference on Nuclear Fuel Performance, October 1973, BNES 1974, Sponsored by the British Nuclear Energy Society.

3. General Atomic Company, HTGR Fuels and Core Development Program Q. Prog. Rep. Aug. 30, 1974, pp. 63-74, GA-A13126. 


\section{TEMPERATURE ANALYSIS}

There are no provisions for direct temperature monitoring or for a sweep gas system in the HT capsules. Therefore, thermal modeling is used to predict maximum fuel operating temperatures. The design temperatures of 1250 and $900^{\circ} \mathrm{C}$ for the high- and low-temperature sleeves, respectively, are relevant because approximately $40 \%$ of the fuel in an HTGR core will operate at or above $900^{\circ} \mathrm{C}$, and approximately $4 \%$ will operate at or above $1250^{\circ} \mathrm{C}$.

The thermal modeling code HTCAP $^{1}$ was used to determine maximum operating temperatures for the fertile fuel particles in capsules HT-12 through HT-15. Maximum particle surface temperatures were calculated at two-day intervals for each HFIR irradiation cycle. Temperature calculations were based on knowledge of the dimensional change characteristics of the graphite sample holders, graphite magazines, and aluminum containment vessel as a function of temperature and fast neutron fluence $(E>0.18 \mathrm{MeV})$; fission heat generated per particle based on isotopic density changes as a function of time; gamma heating rates; changes in material thermal conductivities ${ }^{2}$ as a function of temperature and fast neutron fluence $(E>0.18 \mathrm{MeV})$; and coolant temperatures at the containment surface. A detailed description of the calculational procedure is described in ref. 1 .

Tables 5.1 through 5.3 describe in general the maximum particle surface temperature ranges of specific ORNL coated particle batches for each irradiation cycle. Coated particles in holders 2 through 13 and 42 through 51 were irradiated in the low-flux, low-temperature regions of each capsule. Holders 15 through 38 were irradiated in the high-flux, high-temperature regions of each capsule. Detailed timetemperature histories for each ORNL and GAC coated particle batch are described in Appendix A. For each particle holder in HT-12 through HT-15, the maximum particle surface temperature, the temperature at the outside diameter of the fueled annulus of the sample holder, and the power generated per $\mathrm{ThO}_{2}$ particle are plotted as a function of time from the beginning of irradiation.

Table 5.1. Maximum particle surface temperatures for HT-12

\begin{tabular}{ccccc}
\hline \multirow{2}{*}{$\begin{array}{c}\text { Holder } \\
\text { No. }\end{array}$} & $\begin{array}{c}\text { ORNL } \\
\text { particle } \\
\text { batch }\end{array}$ & $\begin{array}{c}\text { Particle } \\
\text { diameter } \\
(\mu \mathrm{m})\end{array}$ & \multicolumn{2}{c}{$\begin{array}{c}\text { Temperature range }(\mathrm{C}) \\
\text { for HFIR cycles }\end{array}$} \\
\cline { 4 - 5 } & & & 82 & 83 \\
\hline 4 & OR-1850 & 694 & $980-1088$ & $1175-1198$ \\
5 & OR-1846 & 482 & $1005-1114$ & $1209-1225$ \\
8 & OR-1840 & 552 & $1013-1100$ & $1195-1206$ \\
11 & OR-1749 & 540 & $1025-1147$ & $1257-1260$ \\
13 & OR-1849 & 816 & $1152-1179$ & $1293-1274$ \\
17 & OR-1850 & 694 & $1305-1408$ & $1526-1509$ \\
18 & OR-1846 & 482 & $1315-1415$ & $1543-1520$ \\
21 & OR-1840 & 552 & $1314-1379$ & $1495-1466$ \\
24 & OR-1749 & 540 & $1319-1411$ & $1532-1512$ \\
26 & OR-1849 & 816 & $1477-1437$ & $1566-1515$ \\
29 & OR-1838 & 594 & $1319-1385$ & $1501-1473$ \\
32 & OR-1826 & 506 & $1314-1417$ & $1540-1517$ \\
35 & OR-1830 & 480 & $1315-1423$ & $1546-1528$ \\
38 & OR-1837 & 452 & $1497-1454$ & $1578-1534$ \\
42 & OR-1838 & 594 & $1025-1119$ & $1224-1222$ \\
45 & OR-1826 & 506 & $1013-1137$ & $1238-1249$ \\
48 & OR-1830 & 480 & $1065-1139$ & $1237-1247$ \\
51 & OR-1837 & 452 & $1104-1121$ & $1209-1211$ \\
\hline & & & & \\
\hline
\end{tabular}


Table 5.2. Maxımum particle surface temperatures for HT-13

\begin{tabular}{rccccccc}
\hline \multirow{2}{*}{$\begin{array}{c}\text { Holder } \\
\text { No }\end{array}$} & $\begin{array}{c}\text { ORNL } \\
\text { particle } \\
\text { batch }\end{array}$ & $\begin{array}{c}\text { Particle } \\
\text { diameter } \\
(\mu \mathrm{m})\end{array}$ & \multicolumn{5}{c}{ Temperature range ${ }^{\circ}$ C) for HFIR cycles } \\
\cline { 5 - 8 } & & 83 & 84 & 85 & 86 & $87^{a}$ \\
\hline 4 & OR-1840 & 694 & $980-1022$ & $1048-1208$ & $1228-1273$ & $1295-1313$ & 1333 \\
5 & OR-1846 & 482 & $1005-1046$ & $1070-1239$ & $1258-1302$ & $1326-1342$ & 1363 \\
8 & OR-1840 & 552 & $1013-1035$ & $1061-1214$ & $1236-1274$ & $1294-1306$ & 1328 \\
11 & OR-1749 & 540 & $1025-1073$ & $1108-1274$ & $1299-1335$ & $1358-1370$ & 1390 \\
13 & OR-1849 & 816 & $1152-1119$ & $1152-1285$ & $1316-1340$ & $1369-1372$ & 1395 \\
17 & OR-1840 & 694 & $1305-1328$ & $1370-1528$ & $1554-1576$ & $1602-1606$ & 1628 \\
18 & OR-1846 & 482 & $1315-1339$ & $1378-1539$ & $1563-1588$ & $1615-1616$ & 1642 \\
21 & OR-1840 & 552 & $1314-1311$ & $1342-1480$ & $1509-1529$ & $1555-1551$ & 1577 \\
24 & OR-1749 & 540 & $1319-1334$ & $1376-1531$ & $1558-1576$ & $1603-1604$ & 1625 \\
26 & OR-1849 & 816 & $1477-1386$ & $1423-1534$ & $1564-1572$ & $1603-1594$ & 1619 \\
29 & OR-1838 & 594 & $1319-1316$ & $1350-1494$ & $1522-1540$ & $1567-1560$ & 1586 \\
32 & OR-1826 & 506 & $1314-1338$ & $1380-1539$ & $1565-1588$ & $1615-1613$ & 1635 \\
35 & OR-1830 & 480 & $1315-1347$ & $1383-1547$ & $1571-1597$ & $1623-1624$ & 1650 \\
38 & OR-1837 & 452 & $1497-1399$ & $1438-1548$ & $1577-1594$ & $1622-1617$ & 1642 \\
42 & OR-1838 & 594 & $1042-1055$ & $1082-1233$ & $1258-1292$ & $1317-1321$ & 1344 \\
45 & OR-1826 & 506 & $1013-1058$ & $1093-1265$ & $1287-1326$ & $1351-1363$ & 1383 \\
48 & OR-1830 & 480 & $1065-1074$ & $1103-1260$ & $1279-1323$ & $1342-1362$ & 1377 \\
51 & OR-1837 & 452 & $1104-1076$ & $1098-1222$ & $1244-1279$ & $1304-1320$ & 1337 \\
& & & & & & &
\end{tabular}

${ }^{a}$ Capsule HT-13 was urradiated for one day dunng HFIR fuel cycle 87

Table 5.3. Maximum partıcle surface temperature for HT-14 and HT-15

HT-14 - Cycles 85 through 90

HT-15 - Cycles 85 through 91

\begin{tabular}{|c|c|c|c|c|c|c|c|c|c|}
\hline \multirow{2}{*}{$\begin{array}{l}\text { Holder } \\
\text { No }\end{array}$} & \multirow{2}{*}{$\begin{array}{c}\text { ORNL } \\
\text { particle } \\
\text { batch }\end{array}$} & \multirow{2}{*}{$\begin{array}{c}\text { Particle } \\
\text { diameter } \\
(\mu \mathrm{m})\end{array}$} & \multicolumn{7}{|c|}{ Temperature range $\left({ }^{\circ} \mathrm{C}\right)$ for HFIR cycles } \\
\hline & & & 85 & 86 & 87 & 88 & 89 & 90 & 91 \\
\hline 4 & OR-1840 & 694 & $980-1088$ & $1115-1227$ & $1288-1294$ & $1311-1321$ & $1338-1329$ & $1346-1334$ & $1382-1334$ \\
\hline 5 & OR-1846 & 482 & $1005-1114$ & $1144-1257$ & $1317-1323$ & $1340-1347$ & $1364-1362$ & $1377-1367$ & $1410-1359$ \\
\hline 8 & OR-1840 & 552 & $1013-1100$ & $1127-1232$ & $1293-1290$ & $1307-1309$ & $1328-1319$ & $1336-1324$ & $1371-1313$ \\
\hline 11 & OR-1749 & 540 & $1025-1147$ & $1180-1295$ & $1359-1346$ & $1371-1370$ & $1390-1378$ & $1398-1380$ & $1431-1372$ \\
\hline 13 & OR-1849 & 816 & $1152-1179$ & $1212-1306$ & $1377-1351$ & $1377-1372$ & $1395-1377$ & $1400-1376$ & $1431-1362$ \\
\hline 17 & OR-1 840 & 694 & $1305-1408$ & $1442-1542$ & $1616-1587$ & $1611-1606$ & $1627-1606$ & $1630-1600$ & $1659-1588$ \\
\hline 18 & OR-1846 & 482 & $1315-1415$ & $1455-1553$ & $1629-1597$ & $1620-1616$ & $1639-1621$ & $1641-1615$ & $1673-1597$ \\
\hline 21 & OR-1840 & 552 & $1314-1379$ & $1410-1499$ & $1567-1537$ & $1558-1551$ & $1571-1553$ & $1573-1547$ & $1605-1532$ \\
\hline 24 & OR-1749 & 540 & $1319-1411$ & $1449-1543$ & $1620-1584$ & $1611-1604$ & $1622-1603$ & $1624-1594$ & $1654-1580$ \\
\hline 26 & OR-1849 & 816 & $1477-1437$ & $1481-1542$ & $1629-1578$ & $1611-1591$ & $1616-1593$ & $1617-1583$ & $1648-1566$ \\
\hline 29 & OR-1838 & 594 & $1319-1385$ & $1418-1507$ & $1583-1548$ & $1570-1559$ & $1586-1559$ & $1583-1553$ & $1613-1539$ \\
\hline 32 & OR-1826 & 506 & $1314-1417$ & $1454-1550$ & $1629-1597$ & $1623-1613$ & $1632-1613$ & $1636-1607$ & $1668-1592$ \\
\hline 35 & OR-1830 & 480 & $1315-1423$ & $1463-1561$ & $1637-1608$ & $1631-1624$ & $1647-1624$ & $1647-1618$ & $1679-1606$ \\
\hline 38 & OR-1837 & 452 & $1497-1454$ & $1491-1561$ & $1643-1599$ & $1629-1614$ & $1639-1616$ & $1642-1609$ & $1677-1595$ \\
\hline 42 & OR-1838 & 594 & $1025-1119$ & $1147-1249$ & $1316-1305$ & $1325-1324$ & $1341-1332$ & $1354-1337$ & $1385-1323$ \\
\hline 45 & OR-1826 & 506 & $1013-1137$ & $1167-1281$ & $1345-1342$ & $1364-1363$ & $1383-1376$ & $1396-1376$ & $1429-1373$ \\
\hline 48 & OR-1830 & 480 & $1065-1139$ & $1166-1278$ & $1337-1336$ & $1361-1362$ & $1384-1375$ & $1397-1380$ & $1428-1377$ \\
\hline 51 & OR-1837 & 452 & $1104-1121$ & $1145-1239$ & $1296-1297$ & $1314-1320$ & $1342-1335$ & $1352-1342$ & $1387-1339$ \\
\hline
\end{tabular}




\subsection{Discussion}

The thermal analysis of capsules HT-12 through HT-15 indicated that this experiment was more severe than originally designed. The particle sample holders operated between 50 and $200^{\circ} \mathrm{C}$ higher than design temperatures, 900 and $1250^{\circ} \mathrm{C}$, depending upon the holder location in the graphite magazine. The specimen holder temperatures by themselves were not adequate in describing particle operating temperatures. Maximum particle surface temperatures were found to exceed specimen holder temperatures by as much as $100^{\circ} \mathrm{C}$ after one cycle and to peak at approximately $300^{\circ} \mathrm{C}$ higher during the fourth cycle in the high-temperature regions and in the sixth cycle in the low-temperature regions. The particle surface operating temperatures in the low-temperature regions were 1200 to $1300^{\circ} \mathrm{C}$, and in the high-temperature regions were 1500 to $1600^{\circ} \mathrm{C}$. These ranges would apply to approximately $5 \%$ of the total fuel in an HTGR core for the low-temperature regions and less than $1 \%$ for the high-temperature regions. $^{3}$

\section{References}

1. M. J. Kania, HTCAP-A FORTRAN IV Program for Calculating Coated Particle Operating Temperatures in HFIR Target Irradiation Experiments, ORNL/TM-5332 (May 1976).

2. J. P. Moore, R. S. Graves, and D. L. McElroy, "Thermal and Electrical Conductivities and Seebeck Coefficients of Unirradiated and Irradiated Graphites from 300 to $1000^{\circ} \mathrm{K}$," Nucl. Technol. 22, 88-93 (April 1974).

3. Del Marva Power and Light Co., "Preliminary Safety Analysis Report." 


\section{DETERMINATION OF BURNUP FROM FISSION PRODUCT INVENTORIES}

Burnups were determined by two methods. In method 1, fission rate curves for ${ }^{233} \mathrm{U}$ and ${ }^{235} \mathrm{U}$ were produced by independent calculations, and the burnups were calculated through the use of those curves; fission product yields and fission product inventories were determined by gamma-ray spectroscopy. In method 2 the fission products produced and the burnups were calculated as a function of neutron flux by a direct solution to the modified Bateman equations involved in the actinide-to-fission-product chain. Measured values of fission product inventories were then compared with those data to obtain the burnups. The details of these calculations as well as the gamma-ray spectroscopy techniques are given in this chapter. A comparison is made of these burnup values with those calculated for nominal design conditions for the HFIR target position.

\subsection{Gamma-Ray Spectroscopy of Individual Particles}

Selected batches of coated particles were transferred from the High-Radiation-Level Examination Laboratory hot cells to a comparatively clean laboratory where the particles were separated, loaded singly into clean plastic vials, and assigned individual identification numbers. Each particle was then analyzed by gamma-ray spectroscopy.

The analyses were performed on a low-priority schedule and took about a year to complete. During this time, detectors and analyzer equipment changed. The analyzer systems were calibrated primarily with an International Atomic Energy Agency (IAEA) ${ }^{137} \mathrm{Cs}$ gamma-ray standard. Efficiencies at energies other than that of the ${ }^{137} \mathrm{C}$ s gamma ray were determined using the multiple gamma rays of ${ }^{226} \mathrm{Ra}$ for which intensities and energies are well known. ${ }^{1}$ A National Bureau of Standards ${ }^{137}$ Cs gamma-ray calibration standard obtained later agreed well with the IAEA ${ }^{137} \mathrm{Cs}$ gamma-ray standard.

Many of the coated particles were leached to determine coating failures as described in Sect. 8. Some drifts in analytical results were noted during analyses of the same coated particles before and after leaching which could not be ascribed to loss of fission products during leaching. These drifts over a period of approximately a year amount to about $+11 \%$ for ${ }^{106} \mathrm{Ru}$, about $+5 \%$ for ${ }^{125} \mathrm{Sb}, 0$ to $4 \%$ for ${ }^{137} \mathrm{Cs}$, and about $+5 \%$ for ${ }^{144} \mathrm{Ce}$. Only the earlier analyses were available for ${ }^{95} \mathrm{Zr}$ in most of the samples because of its shorter half-life. During the first part of the year, the systems were checked frequently with ${ }^{137} \mathrm{Cs}$ and only occasionally with ${ }^{226} \mathrm{Ra}$. After the drifts were noticed, both nuclides were used for more frequent checks, and a coated particle was also used as a standard.

The analyses of ${ }^{137} \mathrm{Cs}$ are considered to be more accurate because of the frequent calibrations with the ${ }^{137} \mathrm{Cs}$ standard. Also, the ${ }^{137} \mathrm{Cs}$ gamma-ray peak is one of the most prominent in samples that have decayed for a long period. The standard deviation in count rate was influenced by decay time, but generally for these samples, the nuclides in order of increasing error in the count rate were ${ }^{137} \mathrm{Cs},{ }^{144} \mathrm{Ce}$, ${ }^{106} \mathrm{Ru},{ }^{125} \mathrm{Sb}$, and ${ }^{95} \mathrm{Zr}$.

Averages of analytical data for groups of coated particles are given in Appendix B, Table B.1. Disintegration rates were changed to atoms of fission product per initial atom of thorium. The standard deviation (percent) for these values in each group of particles is also given, followed by the average standard deviation [percent (\% error)] for the count rates of the individual particles as determined by the equation

$$
\sigma(\%)=\frac{\sqrt{G+B}}{G-B} \times 100
$$


where

$G=$ gross count,

$B=$ baseline count in the gamma-spectrum peak of interest.

\subsection{Method 1-Burnup Determination}

The burnup determinations were calculated by a rather involved procedure. The counting data for the isotopes ${ }^{95} \mathrm{Zr},{ }^{106} \mathrm{Ru},{ }^{137} \mathrm{Cs}$, and ${ }^{144} \mathrm{Ce}$ were normally considered. The measured disintegration rates for each isotope were corrected for the intensity of a particular energy peak ${ }^{1}$ and for the decay occurring after the end of the irradiation.

In-reactor decay was calculated by a trapezoidal-rule approximation. For example, consider the calculations for ${ }^{95} \mathrm{Zr}$. In the $i$ th time increment, ${ }^{*} t_{i}$, the number of atoms of ${ }^{95} \mathrm{Zr}, A_{\mathrm{Zr}, i}$, generated is

$$
A_{\mathrm{Zr}, i}=\left(Y_{\mathrm{Zr}, 3} \bar{F}_{3, i}^{\prime}+Y_{\mathrm{Zr}, 5} \bar{F}_{5, i}^{\prime}\right) t_{i}
$$

where

$$
\begin{aligned}
Y_{\mathrm{Zr}, 3} & =\text { yield of }{ }^{95} \mathrm{Zr} \text { from }{ }^{233} \mathrm{U} \text { fission in a thermal neutron flux, atoms per fission; } \\
Y_{\mathrm{Zr}, 5} & =\text { yield of }{ }^{95} \mathrm{Zr} \text { from }{ }^{235} \mathrm{U} \text { fission in a thermal neutron flux, atoms per fission; } \\
\bar{F}_{3, i}^{\prime} & =\text { average fission rate for }{ }^{233} \mathrm{U} \text { during time increment } t_{i} \text {, fissions per unit time; } \\
\bar{F}_{5, i}^{\prime} & =\text { average fission rate for }{ }^{235} \mathrm{U} \text { during time increment } t_{i} \text {, fissions per unit time. }
\end{aligned}
$$

The fraction of ${ }^{95} \mathrm{Zr}$ left at the end of the irradiation, $f_{\mathrm{zr}}$, is thus

$$
f_{\mathrm{Zr}}=\frac{\sum_{i} A_{\mathrm{Zr}, i} \exp \left(-0.693 t_{j} / \text { half-life }\right)}{\sum_{i} A_{\mathrm{Zr}, i}},
$$

in which $t_{j}$ is the decay time from the middle of the $i$ th time increment to the end of the irradiation. The nominal time-dependent fission rates at the horizontal midplane (HMP) of the HFIR are calculated with the CACA- $\mathrm{II}^{2}$ computer code, using cross sections in Table 6.1. Similar information was also available at other positions along the axis of the capsule. These data, together with the thermal neutron yields from Meek and Rider, ${ }^{3}$ were then used to calculate the fraction of either ${ }^{95} \mathrm{Zr},{ }^{106} \mathrm{Ru},{ }^{137} \mathrm{Cs}$, or ${ }^{144} \mathrm{Ce}$ remaining at the end of each irradiation. (In the absence of information about yields for ${ }^{234} \mathrm{~Pa}$ fission shown in Fig. 6.1, we assumed that ${ }^{234} \mathrm{~Pa}$ fission could be apportioned equally between ${ }^{233} \mathrm{U}$ and ${ }^{235} \mathrm{U}$ fissions.) These fractional amounts are given in Table 6.1, together with the fraction of ${ }^{233} \mathrm{U}$ fissions for each irradiation. It should be noted that the fractional amounts of each isotope are primarily dependent on the total irradiation time and are not very sensitive to the fraction of ${ }^{233} \mathrm{U}$ fissions, as can be seen, for example, by comparing all the HT-13 values.

The burnup was calculated from the gamma spectroscopy data, the initial moles of actinide, and the fractional amounts given in Table 6.2. For example, the gamma spectroscopy disintegration rate for ${ }^{95} \mathrm{Zr}$ was divided by the fractional amount to give the fission-produced moles, $M_{\mathrm{Zr}}$, by means of the relation

$$
M_{\mathrm{Zr}}=\frac{(\text { corrected disintegrations/sec)(half-life, sec) }}{(0.693) \text { (Avogadro's number) }} .
$$

\footnotetext{
*One 23-day HFIR cycle is an adequately small increment.
} 
Table 6.1. Neutron cross sections used in calculations of fission products and burnup in HT-12 through HT-15 capsules

\begin{tabular}{lrrr}
\hline Nuclide & $\begin{array}{c}\sigma_{f} \\
\text { (barns) }\end{array}$ & $\begin{array}{c}\sigma_{c} \\
\text { (barns) }\end{array}$ & \multicolumn{1}{c}{$\begin{array}{c}\sigma_{a} \\
\text { (barns) }\end{array}$} \\
\hline Th-232 & 0.012 & 4.320 & 4.332 \\
Pa-233 & & 36.600 & 36.600 \\
Pa-234 & 2000.000 & 200.000 & 2200.000 \\
U-233 & 215.000 & 22.000 & 237.000 \\
U-234 & & 48.100 & 48.100 \\
U-235 & 215.000 & 39.300 & 254.300 \\
U-236 & & 10.000 & 10.000 \\
U-237 & & 140.000 & 140.000 \\
U-238 & 0.047 & 5.420 & 5.467 \\
Np-237 & & 60.000 & 60.000 \\
Np-238 & 700.000 & 18.000 & 718.000 \\
Np-239 & & 11.000 & 11.000 \\
Pu-238 & & 160.000 & 160.000 \\
Pu-239 & 351.000 & 153.000 & 504.000 \\
Pu-240 & & 356.000 & 356.000 \\
Pu-241 & 442.000 & 142.000 & 584.000 \\
Pu-242 & & 35.000 & 35.000 \\
Sr-90 & & 0.800 & 0.800 \\
Zr-95 & & 0.000 & 0.000 \\
Ru-106 & & 0.146 & 0.146 \\
Sb-125 & & 0.000 & 0.000 \\
Cs-137 & & 0.110 & 0.110 \\
Ce-144 & & 1.000 & 1.000 \\
\hline & & &
\end{tabular}

Note: $\sigma_{f}=$ fission cross section, $\sigma_{c}=$ capture cross section, $\sigma_{a}=$ total cross section.

Table 6.2. In-reactor decay factors and ${ }^{233} \mathrm{U}$ fission

\begin{tabular}{|c|c|c|c|c|c|c|}
\hline \multirow{2}{*}{$\begin{array}{l}\text { Irradiation } \\
\text { No. }\end{array}$} & \multirow{2}{*}{$\begin{array}{l}\text { Irradiation } \\
\text { time (days) }\end{array}$} & \multicolumn{4}{|c|}{ Fraction remaining at discharge } & \multirow{2}{*}{$\begin{array}{c}\text { Fraction } \\
{ }^{233} \mathrm{U} \text { fissions }\end{array}$} \\
\hline & & ${ }^{95} \mathrm{Zr}$ & ${ }^{106} \mathrm{Ru}$ & ${ }^{137} \mathrm{Cs}$ & ${ }^{144} \mathrm{Ce}$ & \\
\hline HT-12-26, -21 & 38.6 & 0.862 & 0.973 & 0.999 & 0.966 & 0.813 \\
\hline HT-13-26, -29 & 85.6 & 0.684 & 0.933 & 0.998 & 0.913 & 0.767 \\
\hline HT-14-26, -29 & 137.0 & 0.580 & 0.900 & 0.996 & 0.872 & 0.720 \\
\hline HT-15-26, -29 & 160.0 & 0.524 & 0.881 & 0.996 & 0.848 & 0.707 \\
\hline HT-13-21, -13 & 85.6 & 0.715 & 0.939 & 0.998 & 0.922 & 0.773 \\
\hline HT-14-21 & 137.0 & 0.583 & 0.901 & 0.996 & 0.873 & 0.727 \\
\hline HT-12-13 & 38.6 & 0.862 & 0.973 & 0.999 & 0.965 & 0.817 \\
\hline HT-14-13 & 137.0 & 0.595 & 0.904 & 0.997 & 0.878 & 0.749 \\
\hline HT-15-13 & 160.0 & 0.544 & 0.887 & 0.996 & 0.856 & 0.738 \\
\hline HT-12-8 & 38.6 & 0.860 & 0.973 & 0.999 & 0.965 & 0.820 \\
\hline HT-13-8 & 85.6 & 0.730 & 0.943 & 0.998 & 0.926 & 0.796 \\
\hline HT-14-8 & 137.0 & 0.601 & 0.907 & 0.997 & 0.881 & 0.758 \\
\hline HT-15-8 & 160.0 & 0.551 & 0.889 & 0.996 & 0.859 & 0.750 \\
\hline HRB6-1C-1, -2 & 184.0 & 0.279 & 0.763 & 0.991 & 0.717 & 0.331 \\
\hline P13LC4T6 & 423.5 & 0.297 & 0.754 & 0.990 & 0.698 & 1.00 \\
\hline
\end{tabular}




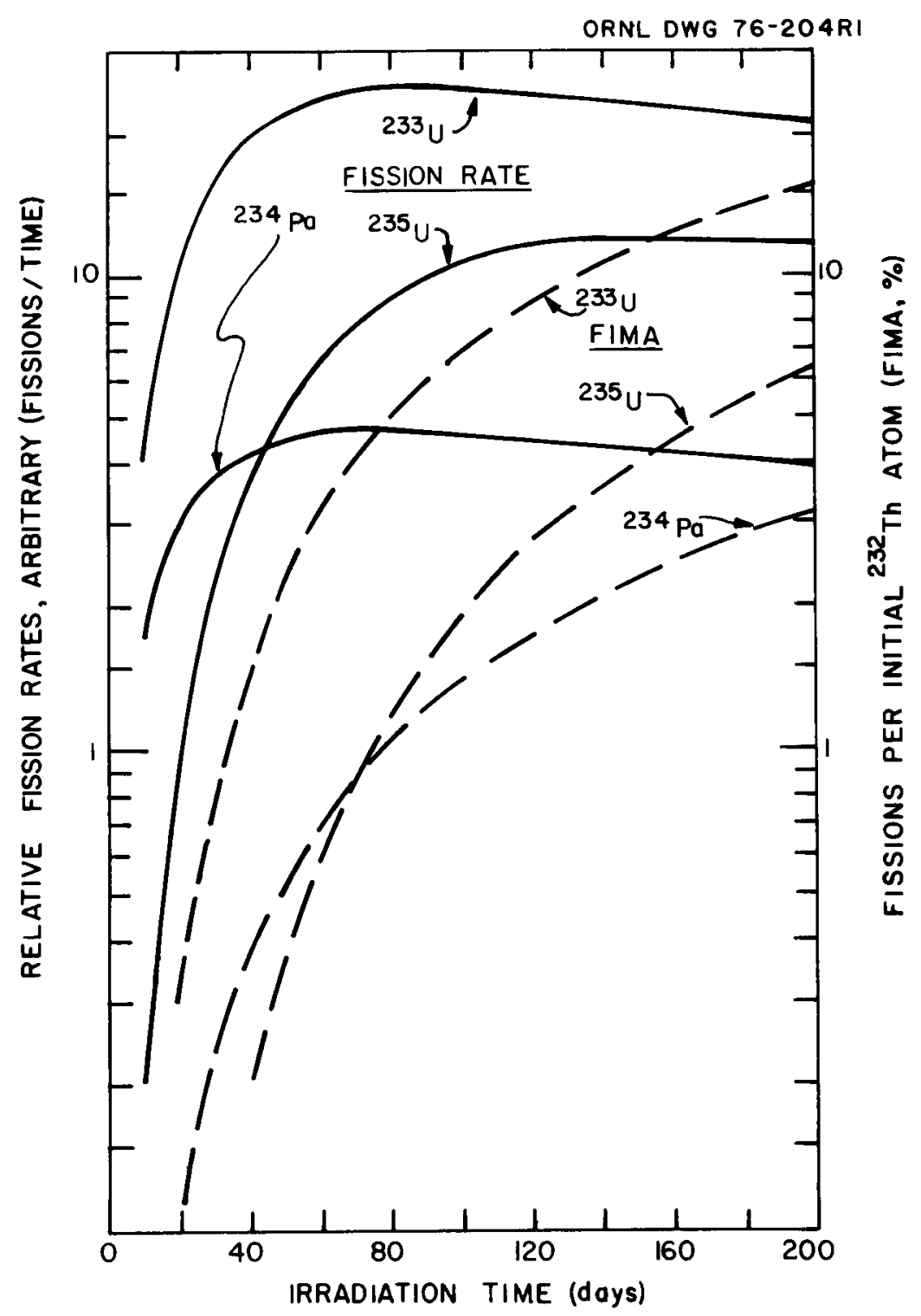

Fig. 6.1. Nominal calculated fission rates and burnup in the target region of the HFIR at the horizontal midplane.

Finally, the burnup was calculated by the relation

$$
\% \text { FIMA }=\frac{100 \% \times M_{\mathrm{Zr}}}{\text { (initial moles actinide) }\left(f_{3} Y_{\mathrm{Zr}, 3}+f_{5} Y_{\mathrm{Zr}, 5}\right)},
$$

where

FIMA $=$ fissions per initial heavy-metal atom,

$f_{3}=$ fraction ${ }^{233} \mathrm{U}$ fissions (Table 6.2),

$f_{5}=$ fraction ${ }^{235} \mathrm{U}$ fissions $\left(=1-f_{3}\right)$. 


\subsection{Method 2-Determination of Burnup, Effective Neutron Flux, and Fission Product Inventories}

Fission product inventories per original atom of thorium were calculated as a function of neutron flux, using the effective neutron cross sections for actinides in the A-2 type facilities of the HFIR. The cross sections used for the fission products are for thermal neutrons and were obtained from the tabulation by Goldberg et al. ${ }^{4,5,6}$ All of the cross sections used are presented in Table 6.1; the irradiation history is given in Table 3.1; geometry factors for distance from the horizontal midplane are given in Table 6.3. These are compared with geometry factors calculated from the ${ }^{144} \mathrm{Ce}$ analyses. The fission product yields are taken from a compilation by Meek and Rider, ${ }^{7}$ and half-lives are from the GE Chart of the Nuclides. ${ }^{8}$

Although many computer programs exist for determining fission product inventories and burnup, ${ }^{2,9,10}$ most of these involve extensive input and output data, many of which are not essential in certain problems. FORTRAN IV was used because it is easily adapted to change on the PDP-10; it fits various problems and produces the output in a convenient form. A shorthand notation for the generation of the modified Bateman equations ${ }^{11}$ was developed which is easily adaptable to any nuclide production-decay chain and is easily translated to FORTRAN IV language.

The equations used for calculating the fission product inventories and burnup were derived by solving the differential equations for production, activation, and decay of the various nuclides in the chain from ${ }^{232} \mathrm{Th}$ to fission products. The generalized solution is given as follows:

$$
\begin{aligned}
N_{i}= & i \text { th nuclide in chain (atoms at time } t) ; \\
N_{i}^{0}= & \text { original amount of } i \text { th nuclide in chain (atoms) at time } 0 ; \\
\alpha_{i}= & \left(\Phi \sigma_{a}+\lambda\right)_{i}=\text { loss rate term for the } i \text { th nuclide, where } \Phi=\text { neutron flux (neutrons } \\
& \left.\mathrm{cm}^{-2} \sec ^{-1}\right), \sigma_{a}=\text { adsorption cross section }\left(\mathrm{cm}^{2}\right), \text { and } \lambda=\operatorname{decay~constant~}\left(\mathrm{sec}^{-1}\right) ; \\
A_{i}= & \text { either of } \Phi \sigma_{f}, \Phi \sigma_{c}, \text { or } \lambda \text { as applicable for the production of the }(i+1) \text { th nuclide } \\
& \text { from the } i \text { th nuclide, where } \sigma_{f}=\text { fission cross section }\left(\mathrm{cm}^{2}\right), \text { and } \sigma_{c}=\text { activation cross } \\
& \text { section }\left(\mathrm{cm}^{2}\right) ; \\
A_{i, m}= & \left(\Phi \sigma_{f} y\right)_{i} \text { for production of fission product } m \text { from the } i \text { th nuclide, where } y=\text { yield; } \\
C(i, j)= & \left(\alpha_{j}-\alpha_{i}\right)^{-1} ; \\
E(i)= & \exp \left(-\alpha_{i t} t\right), \text { where } t=\text { irradiation time }(\mathrm{sec}) ; \\
E(i, j)= & C(i, j)[E(i)-E(j)] ; \\
E(1,2,3, \ldots, n)= & C(1,2)[E(1,3,4, \ldots, n)-E(2,3,4, \ldots, n)] .
\end{aligned}
$$

Table 6.3. Geometry factors for neutron flux for the HT capsules

Note: $3.267 \mathrm{E}+15$ is read $3.267 \times 10^{15}$

\begin{tabular}{ccccc}
\hline Holder & $\begin{array}{c}\text { Distance } \\
\text { from HMP } \\
\text { (in.) }\end{array}$ & $\begin{array}{c}\text { Calculated } \\
\text { factor }\end{array}$ & $\begin{array}{c}\text { Neutron flux } \\
\text { based on } \mathbf{1 3 7}^{7} \mathrm{Cs} \\
\text { (neutrons cm } \mathrm{cm}^{-2} \mathrm{sec}^{-1} \text { ) }\end{array}$ & $\begin{array}{c}\text { Geometry factor } \\
\text { based on }{ }^{144} \mathrm{Ce} \\
\text { analyses }\end{array}$ \\
\hline 8 & 7.21 & 0.66 & $3.267 \mathrm{E}+15$ & 0.66 \\
13 & 5.80 & 0.77 & $3.812 \mathrm{E}+15$ & 0.75 \\
21 & 2.21 & 0.94 & $4.653 \mathrm{E}+15$ & 0.95 \\
29 & 1.37 & 0.97 & $4.802 \mathrm{E}+15$ & 1.00 \\
26 & 0.80 & 0.99 & $4.900 \mathrm{E}+15$ & 0.96 \\
HMP & 0.00 & 1.00 & $4.950 \mathrm{E}+15$ & 1.00 \\
\hline
\end{tabular}


Then

$N_{n}=\left[{ }_{i=1}^{n-1} A_{i}\right] N_{1}^{0} E(1,2, \ldots, n)+\left[\prod_{n=2}^{n-1} A_{i}\right] N_{2}^{0} E(2,3, \ldots, n)+\ldots+A_{n-1} N_{n-1}^{0} E(n-1, n)+N_{n}^{0} E(n)$.

The nuclide production chain is shown in Fig. 6.2. Parallel sections in the chain are solved by special adaptations.

The burnup (fissions per original atom of thorium or FIMA) was calculated by

$$
\text { FIMA }=1-\sum_{i=1}^{J} N_{i},
$$

where $N_{i}=$ concentration of the $i$ th actinide and $J=$ total number of actinides in ${ }^{232}$ Th chain of Fig. 6.2.

The calculated fission product inventories are given in Appendix B, Tables B.2 through B.5. The analyzed concentrations of several fission products were used to obtain neutron fluxes by interpolation of the calculated values in Tables B.6 through B.9. These neutron fluxes are given in Table 6.4. The average values derived from ${ }^{95} \mathrm{Zr},{ }^{106} \mathrm{Ru}$, and ${ }^{144} \mathrm{Ce}$ are also presented in the table. Values from ${ }^{125} \mathrm{Sb}$ and ${ }^{137} \mathrm{Cs}$ were omitted from the averages because these fission products were lost at high temperatures during irradiation. The average neutron flux for each holder was divided by the calculated geometry factor for distance from the horizontal midplane in the reactor in order to calculate the maximum neutron flux from each coated-particle sample. The average of these values, weighted according to the

ORNL DWG. $76-1160$

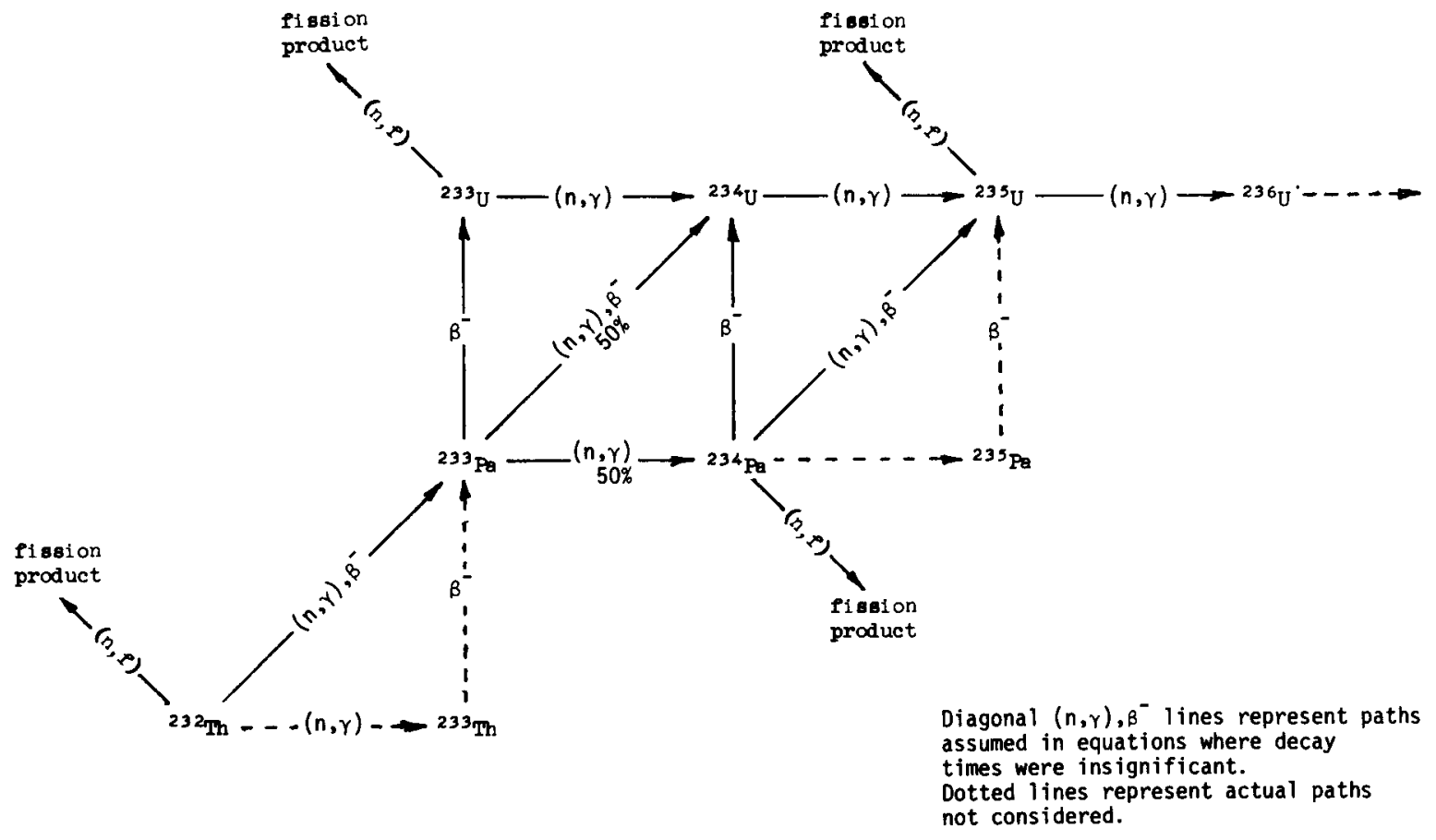

Fig. 6.2. Chain for the production of fission products from ${ }^{232} \mathrm{Th}$. 
Table 6.4. Effective neutron fluxes for HT-12 through HT-15 irradiation experiments calculated from fission product inventories in $\mathrm{BISO}$-coated $\mathrm{ThO}_{2}$ particles

Note: $2.704 \mathrm{E}+15$ is read $2.704 \times 10^{15}$

\begin{tabular}{|c|c|c|c|c|c|c|c|c|c|}
\hline \multirow{2}{*}{ Experiment } & \multirow{2}{*}{$\begin{array}{l}\text { Number of } \\
\text { particles } \\
\text { examined }\end{array}$} & \multirow{2}{*}{$\begin{array}{l}\text { Attenuation } \\
\text { factor }\end{array}$} & \multicolumn{5}{|c|}{ Neutron flux (neutrons $\mathrm{cm}^{-2} \mathrm{sec}^{-1}$ ) from inventories of: } & \multirow{2}{*}{$\begin{array}{c}\text { Average }^{a} \\
\text { neutron flux } \\
\text { (neutrons } \mathrm{cm}^{-1} \mathrm{sec}^{-1} \text { ) }\end{array}$} & \multirow{2}{*}{$\begin{array}{c}\text { Average }^{b} \text { neutron } \\
\text { flux at HMP } \\
\text { (neutrons } \mathrm{cm}^{-2} \sec ^{-1} \text { ) }\end{array}$} \\
\hline & & & ${ }^{95} \mathrm{Zr}$ & ${ }^{106} \mathrm{Ru}$ & ${ }^{144} \mathrm{Ce}$ & ${ }^{125} \mathrm{Sb}$ & ${ }^{137} \mathrm{Cs}$ & & \\
\hline HT-12-8 & $16^{c}$ & 0.66 & $2.704 \mathrm{E}+15$ & $3.268 \mathrm{E}+15$ & $3.024 \mathrm{E}+15$ & $3.459 \mathrm{E}+15$ & $3.278 \mathrm{E}+15$ & $2.999 \mathrm{E}+15$ & $4.544 \mathrm{E}+15$ \\
\hline HT-12-13 & $16^{c}$ & 0.77 & $3.136 \mathrm{E}+15$ & $3.656 \mathrm{E}+15$ & $3.442 \mathrm{E}+15$ & $3.917 \mathrm{E}+15$ & $3.726 \mathrm{E}+15$ & $3.411 \mathrm{E}+15$ & $4.430 \mathrm{E}+15$ \\
\hline HT-12-21 & $16^{c}$ & 0.94 & $3.664 \mathrm{E}+15$ & $4.530 \mathrm{E}+15$ & $4.277 \mathrm{E}+15$ & $4.803 \mathrm{E}+15$ & $4.644 \mathrm{E}+15$ & $4.157 \mathrm{E}+15$ & $4.422 \mathrm{E}+15$ \\
\hline HT-12-26 & $15^{c}$ & 0.99 & $3.948 \mathrm{E}+15$ & $4.543 \mathrm{E}+15$ & $4.356 \mathrm{E}+15$ & $4.926 \mathrm{E}+15$ & $4.729 \mathrm{E}+15$ & $4.282 \mathrm{E}+15$ & $4.325 \mathrm{E}+15$ \\
\hline HT-12-26 & $1^{d}$ & 0.99 & $3.594 \mathrm{E}+15$ & $3.985 E+15$ & $4.146 \mathrm{E}+15$ & $4.926 \mathrm{E}+15$ & $4.644 \mathrm{E}+15$ & $3.908 \mathrm{E}+15$ & $3.947 \mathrm{E}+15$ \\
\hline HT-1 3-8 & $1^{d}$ & 0.66 & $2.729 \mathrm{E}+15$ & $3.123 \mathrm{E}+15$ & $2.997 \mathrm{E}+15$ & $3.280 \mathrm{E}+15$ & $3.306 \mathrm{E}+15$ & $2.950 \mathrm{E}+15$ & $4.470 \mathrm{E}+15$ \\
\hline HR-13-13 & $15^{c}$ & 0.77 & $3.000 \mathrm{E}+15$ & $3.827 \mathrm{E}+15$ & $3.521 \mathrm{E}+15$ & $3.744 \mathrm{E}+15$ & $3.906 \mathrm{E}+15$ & $3.449 \mathrm{E}+15$ & $4.479 \mathrm{E}+15$ \\
\hline HT-13-21 & $18^{c}$ & 0.94 & $4.055 \mathrm{E}+15$ & $4.488 \mathrm{E}+15$ & $4.309 \mathrm{E}+15$ & $4.053 \mathrm{E}+15$ & $3.923 \mathrm{E}+15$ & $4.284 \mathrm{E}+15$ & $4.557 \mathrm{E}+15$ \\
\hline HT-13-26 & $19^{c}$ & 0.99 & $3.961 \mathrm{E}+15$ & $4.700 \mathrm{E}+15$ & $4.410 \mathrm{E}+15$ & $4.582 \mathrm{E}+15$ & $3.957 \mathrm{E}+15$ & $4.357 \mathrm{E}+15$ & $4.401 \mathrm{E}+15$ \\
\hline HT-1 3-29 & $18^{e}$ & 0.97 & $4.209 \mathrm{E}+15$ & $4.909 \mathrm{E}+15$ & $4.561 \mathrm{E}+15$ & $4.698 \mathrm{E}+15$ & $4.786 \mathrm{E}+15$ & $4.560 \mathrm{E}+15$ & $4.701 \mathrm{E}+15$ \\
\hline HT-14-8 & $1^{c}$ & 0.66 & $2.661 \mathrm{E}+15$ & $3.230 E+15$ & $2.905 E+15$ & $3.120 \mathrm{E}+15$ & $3.443 E+15$ & $2.932 \mathrm{E}+15$ & $4.442 \mathrm{E}+15$ \\
\hline HT-14-8 & $15^{d}$ & 0.66 & $2.734 \mathrm{E}+15$ & $3.288 \mathrm{E}+15$ & $3.005 \mathrm{E}+15$ & $3.000 \mathrm{E}+15$ & $3.327 \mathrm{E}+15$ & $3.009 \mathrm{E}+15$ & $\begin{array}{l}4.442 \mathrm{E}+13 \\
4.559 \mathrm{E}+15\end{array}$ \\
\hline HT-14-13 & $17^{f}$ & 0.77 & $3.322 \mathrm{E}+15$ & $3.870 \mathrm{E}+15$ & $3.488 \mathrm{E}+15$ & $3.382 \mathrm{E}+15$ & $3.539 \mathrm{E}+15$ & $3.560 \mathrm{E}+15$ & $4.623 \mathrm{E}+15$ \\
\hline HT-14-21 & $12^{c}$ & 0.94 & $4.377 \mathrm{E}+15$ & $3.230 \mathrm{E}+15$ & $4.697 \mathrm{E}+15$ & $4.194 \mathrm{E}+15$ & $3.139 \mathrm{E}+15$ & $4.101 \mathrm{E}+15$ & $4.363 \mathrm{E}+15$ \\
\hline HT-14-26 & $1^{e}$ & 0.99 & $4.829 \mathrm{E}+15$ & $5.057 \mathrm{E}+15$ & $4.838 \mathrm{E}+15$ & $4.017 \mathrm{E}+15$ & $2.413 \mathrm{E}+15$ & $4.908 \mathrm{E}+15$ & $4.958 \mathrm{E}+15$ \\
\hline HT-15-8 & $13^{b}$ & 0.66 & $2.909 \mathrm{E}+15$ & $3.341 \mathrm{E}+15$ & $2.985 \mathrm{E}+15$ & $2.994 \mathrm{E}+15$ & $<2.4 \mathrm{E}+15$ & $3.078 \mathrm{E}+15$ & $4.664 \mathrm{E}+15$ \\
\hline HT- $15-13$ & $1^{c}$ & 0.77 & $3.352 \mathrm{E}+15$ & $3.995 \mathrm{E}+15$ & $3.490 \mathrm{E}+15$ & $3.390 \mathrm{E}+15$ & $3.418 \mathrm{E}+15$ & $3.612 \mathrm{E}+15$ & $4.691 \mathrm{E}+15$ \\
\hline HT-15-13 & $7^{d}$ & 0.77 & $3.276 \mathrm{E}+15$ & $4.143 \mathrm{E}+15$ & $3.432 \mathrm{E}+15$ & $3.237 \mathrm{E}+15$ & $<2.4 \mathrm{E}+15$ & $3.617 \mathrm{E}+15$ & $4.697 \mathrm{E}+15$ \\
\hline HT- $15-26$ & $19^{c}$ & 0.99 & $4.262 \mathrm{E}+15$ & $4.866 \mathrm{E}+15$ & $\begin{array}{l}3.472 \mathrm{E}+13 \\
4.470 \mathrm{E}+15\end{array}$ & $3.175 \mathrm{E}+15$ & $3.619 \mathrm{E}+15$ & $\begin{array}{l}3.533 \mathrm{E}+15 \\
4.517 \mathrm{~T}\end{array}$ & $\begin{array}{l}4.097 \mathrm{E}+13 \\
4.579 \mathrm{E}+15\end{array}$ \\
\hline \multirow[t]{2}{*}{ HT-15-29 } & $19^{e}$ & 0.97 & $4.525 \mathrm{E}+15$ & $5.323 \mathrm{E}+15$ & $4.657 \mathrm{E}+15$ & $3.756 E+15$ & $2.541 \mathrm{E}+15$ & $4.835 \mathrm{E}+15$ & $4.985 \mathrm{E}+15$ \\
\hline & & & & & & & & Weighted average & age $\quad 4.5608 \mathrm{E}+15$ \\
\hline
\end{tabular}

${ }^{a}$ Average does not include data from ${ }^{125} \mathrm{Sb}$ and ${ }^{137} \mathrm{Cs}$.

${ }^{b}$ Average at HMP obtained by dividing the average neutron flux for each holder by its attenuation factor for distance from the HMP.

${ }^{c}$ Particle coating survival as determined by hot chlorine leaching.

${ }^{d}$ Particle coating failure as determined by hot chlorine leaching.

${ }^{e}$ Coated particles not tested by hot chlorine leaching.

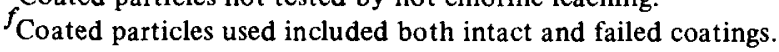


number of coated particles in the samples analyzed, was $4.6 \times 10^{15}$ neutrons $\mathrm{cm}^{-2} \mathrm{sec}^{-1}$. The coatedparticle samples used in these calculations were separated into groups with intact, failed, or untested coatings. Coating failure caused no apparent release of ${ }^{95} \mathrm{Zr},{ }^{106} \mathrm{Ru}$, or ${ }^{144} \mathrm{Ce}$, as will be discussed in Sect. 9.1, and this is also indicated in the similar values of neutron fluxes calculated from these fission product inventories in intact and failed coated particles from the same batch and irradiation holder.

The burnups were determined by the same procedure as were the neutron fluxes, using the fission product inventories and the tables in Appendix B.

\subsection{Results and Discussion}

The average burnup values as computed by methods 1 and 2 for all coated particles in a given set are given in Table 6.5. The values obtained from ${ }^{95} \mathrm{Zr},{ }^{106} \mathrm{Ru}$, and ${ }^{144} \mathrm{Ce}$ analyses were averaged in the last column. Values from ${ }^{137} \mathrm{Cs}$ were omitted from the final averages because these fission products are partially lost during irradiation to high burnups and temperatures. The same data from the B samples, Table 6.5 , were used in calculations by both methods. The results indicate that the methods are equivalent.

It should be noted that burnups calculated from ${ }^{95} \mathrm{Zr}$ and ${ }^{144} \mathrm{Ce}$ are nearly equal, whereas those from ${ }^{106} \mathrm{Ru}$ are higher. In coated particles irradiated to lower burnups at the lower temperatures where cesium was apparently not lost, values calculated from ${ }^{137} \mathrm{Cs}$ inventories were higher than those of the other three isotopes. The lower burnups calculated from ${ }^{137} \mathrm{Cs}$ at higher temperatures and burnups reflect the cesium loss in these samples. The wide variations are possibly due to errors in geometry factors and cross sections or to the difference between the actual yields in the HFIR and the thermal neutron yields from Meek and Rider. An additional inconsistency is seen in a comparison of the burnups determined from the fission product inventories with those calculated by other methods, using data from conventional dosimetry. This comparison is illustrated by the plot of burnups in Fig. 6.3. The bars on the data points represent the range of the burnups determined from ${ }^{95} \mathrm{Zr},{ }^{106} \mathrm{Ru}$, and ${ }^{144} \mathrm{Ce}$ inventories. The calculated burnups are given in the summary of burnups and neutron fluxes in Table 6.6.

A linear least-squares fit for a line forced through the origin was calculated for the data for each irradiation holder. The slope $(b)$ is proportional to the variation between the burnups determined from fission product inventories and those calculated conventionally. The slope and the distance of the holder from the HMP of the reactor are given in the table inset in Fig. 6.3 and are plotted in Fig. 6.3b. The increase in $b$ with the distance may indicate an error in the geometry factors used in the calculations of the burnup. 
Table 6.5. Burnup values for HT-12 through $\mathrm{HT}-15$ Biso-coated $\mathrm{ThO}_{2}$ particles from fission product inventories

\begin{tabular}{|c|c|c|c|c|c|c|c|}
\hline \multirow{2}{*}{$\begin{array}{l}\text { Sample } \\
\text { No }\end{array}$} & \multirow{2}{*}{$\begin{array}{l}\text { Burnup } \\
\text { calculation } \\
\text { method }\end{array}$} & \multirow{2}{*}{$\begin{array}{c}\text { Number } \\
\text { of } \\
\text { particles }\end{array}$} & \multicolumn{4}{|c|}{ Burnup in \% FIMA from inventory of } & \multirow{2}{*}{ Average $^{b}$} \\
\hline & & & ${ }^{95} \mathrm{Zr}$ & ${ }^{106} \mathrm{Ru}$ & ${ }^{144} \mathrm{Ce}$ & $\overline{{ }^{137} \mathrm{Cs}}$ & \\
\hline HT $12-8-B$ & 1 & 16 & 073 & 090 & 084 & 100 & 082 \\
\hline$-B$ & 2 & 16 & 071 & 095 & 084 & 096 & 083 \\
\hline HT-13-8-A & 1 & 6 & 354 & 347 & 341 & 409 & 347 \\
\hline B & 1 & 15 & 313 & 414 & 387 & 461 & 371 \\
\hline$-B$ & 2 & 15 & 315 & 433 & 390 & 444 & 379 \\
\hline HT-14-8-A & 1 & 6 & 767 & 767 & 728 & 856 & 754 \\
\hline$-B$ & 1 & 15 & 723 & 862 & 796 & 941 & 794 \\
\hline$-B$ & 2 & 15 & 721 & 897 & 807 & 909 & 808 \\
\hline HT-15-8-A & 1 & 6 & 931 & 918 & 970 & 657 & 906 \\
\hline$-\mathrm{B}$ & 1 & 13 & 965 & 110 & 988 & 725 & 102 \\
\hline$-B$ & 2 & 13 & 977 & 114 & 101 & & 104 \\
\hline HT-12-13 B & 1 & 16 & 091 & 108 & 104 & 122 & 101 \\
\hline$-B$ & 2 & 16 & 089 & 114 & 103 & 117 & 102 \\
\hline HT-13-13-B & 1 & 15 & 382 & 501 & 466 & 555 & 450 \\
\hline$-B$ & 2 & 15 & 379 & 520 & 467 & 534 & 455 \\
\hline HT-14-13-A & 1 & 6 & 971 & 938 & 885 & 102 & 931 \\
\hline$-\mathrm{B}$ & 1 & 17 & 914 & 106 & 950 & 101 & 975 \\
\hline$-B$ & 2 & 17 & 908 & 108 & 961 & 977 & 983 \\
\hline HT-15-13-A & 1 & 6 & 117 & 109 & 106 & 728 & 111 \\
\hline$-\mathrm{B}$ & 1 & 7 & 113 & 135 & 116 & 692 & 121 \\
\hline$-B$ & 2 & 7 & 112 & 138 & 118 & & 123 \\
\hline HT-12-21-B & 1 & 16 & 116 & 152 & 145 & 171 & 138 \\
\hline$-B$ & 2 & 16 & 114 & 158 & 145 & 164 & 139 \\
\hline HT-13-21 A & 1 & 10 & 601 & 618 & 608 & 582 & 609 \\
\hline$-\mathrm{B}$ & 1 & 18 & 563 & 623 & 602 & 556 & 596 \\
\hline$-B$ & 2 & 18 & 560 & 637 & 605 & 537 & 601 \\
\hline HT-14-21-A & 1 & 8 & 135 & 141 & 129 & 844 & 135 \\
\hline$-B$ & 1 & 12 & 127 & 153 & 134 & 909 & 138 \\
\hline$-B$ & 2 & 12 & 125 & 153 & 135 & 849 & 138 \\
\hline HT-12 26-A & 1 & 5 & 155 & 142 & 143 & 189 & 147 \\
\hline$-B$ & 1 & 15 & 128 & 153 & 149 & 175 & 143 \\
\hline$-B$ & 2 & 15 & 128 & 158 & 149 & 168 & 145 \\
\hline HT-13-26-A & 1 & 7 & 716 & 658 & 630 & 544 & 668 \\
\hline$-B$ & 1 & 19 & 568 & 666 & 637 & 585 & 624 \\
\hline$-B$ & 2 & 19 & 544 & 676 & 623 & 543 & 614 \\
\hline HT-14-26 A & 1 & 5 & 155 & 155 & 140 & 965 & 150 \\
\hline$-B$ & 1 & 1 & 141 & 149 & 139 & 648 & 143 \\
\hline$-B$ & 2 & 1 & 140 & 147 & 140 & 620 & 143 \\
\hline HT-15-26-A & 1 & 10 & 177 & 177 & 163 & 140 & 172 \\
\hline$-B$ & 1 & 19 & 152 & 171 & 156 & 129 & 160 \\
\hline$-B$ & 2 & 19 & 150 & 173 & 158 & 125 & 160 \\
\hline HT-13-29-A & 1 & 6 & & 671 & 646 & 710 & \\
\hline$-B$ & 2 & 18 & 587 & 7.14 & 650 & 962 & 650 \\
\hline HT-14-29-A & 1 & 6 & 137 & 197 & 134 & 514 & 143 \\
\hline HT-15-29-A & 1 & 6 & 158 & 177 & 156 & 555 & 164 \\
\hline -B & 1 & 19 & 161 & 189 & 163 & 872 & 171 \\
\hline$-B$ & 2 & 19 & 160 & 191 & 165 & 836 & 172 \\
\hline
\end{tabular}

${ }^{a}$ Consists of the irradiation holder number followed by a letter indicating a particular group of particles from that holder The data from the B groups were used in calculations by both methods as a comparison

${ }^{b}$ Does not include the burnup calculated from ${ }^{137} \mathrm{Cs}$ 


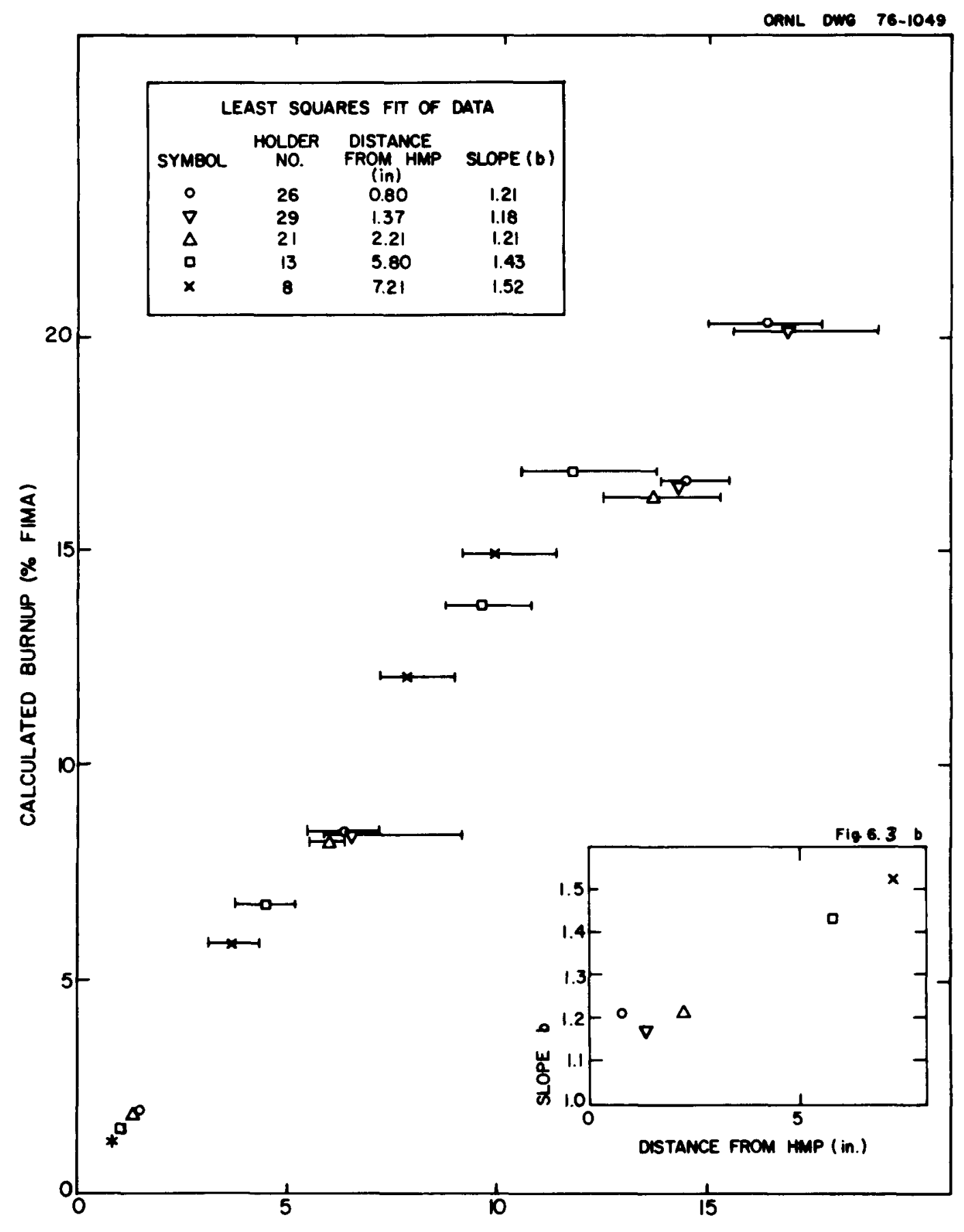

Fig. 6.3. Comparison of calculated burnups vs burnups determined from fission products. 
Table 6.6. Irradiation summary for capsules HT-12 through HT-15

\begin{tabular}{|c|c|c|c|c|c|c|c|c|c|c|c|}
\hline \multirow{2}{*}{\multicolumn{2}{|c|}{$\begin{array}{l}\text { Sample holder } \\
\text { Nos }\end{array}$}} & \multirow{2}{*}{$\begin{array}{c}\text { Distance } \\
\text { from specimen } \\
\text { holder to HMP } \\
\text { (in ) }\end{array}$} & \multirow{2}{*}{$\begin{array}{l}\text { Thermal } \\
\text { flux }\end{array}$} & \multirow{2}{*}{$\begin{array}{l}\text { Fast } \\
\text { flux }\end{array}$} & \multirow{2}{*}{$\begin{array}{l}\text { Fast } \\
\text { flux }\end{array}$} & \multicolumn{2}{|c|}{$\begin{array}{c}\text { Ratio, } \\
\text { fast/thermal }\end{array}$} & \multicolumn{4}{|c|}{ Fertile particle burnup (\% FIMA) } \\
\hline & & & & & & $b / a$ & $\overline{c / a}$ & HТ-12 & HT -13 & HT-14 & HT-15 \\
\hline \multicolumn{12}{|c|}{ Low temperature } \\
\hline 2 & 51 & 8909 & 175 & 141 & 059 & 081 & 042 & 095 & 453 & 956 & 1191 \\
\hline 4 & 49 & 8344 & 187 & 157 & 067 & 084 & 043 & 106 & 500 & 1045 & 1300 \\
\hline 5 & 48 & 8061 & 193 & 167 & 070 & 087 & 042 & 110 & 520 & 1090 & 1350 \\
\hline 7 & 46 & 7496 & 205 & 185 & 076 & 090 & 041 & 121 & 562 & 1167 & 1442 \\
\hline 8 & 45 & 7214 & 211 & 192 & 080 & 091 & 042 & 126 & 584 & 1205 & 1490 \\
\hline 10 & 43 & 6649 & 224 & 208 & 085 & 093 & 041 & 137 & 622 & 1275 & 1572 \\
\hline 11 & 42 & 6366 & 231 & 216 & 088 & 094 & 041 & 140 & 640 & 1308 & 1610 \\
\hline 13 & 40 & 5801 & 242 & 230 & 093 & 095 & 040 & 150 & 675 & 1370 & 1682 \\
\hline \multicolumn{12}{|c|}{ High temperature } \\
\hline 15 & 98 & 3909 & 283 & 270 & 108 & 095 & 039 & 171 & 770 & 1530 & 1872 \\
\hline 17 & 36 & 3344 & 294 & 280 & 109 & 095 & 039 & 178 & 790 & 1567 & 1912 \\
\hline 18 & 35 & 3061 & 300 & 283 & 111 & 094 & 039 & 180 & 800 & 1582 & 1932 \\
\hline 20 & 33 & 2496 & 310 & 291 & 113 & 094 & 039 & 182 & 815 & 1610 & 1965 \\
\hline 21 & 32 & 2214 & 313 & 294 & 114 & 094 & 039 & 186 & 821 & 1621 & 1980 \\
\hline 23 & 30 & 1649 & 319 & 300 & 116 & 094 & 039 & 190 & 833 & 1642 & 2003 \\
\hline 24 & 29 & 1366 & 322 & 303 & 116 & 094 & 038 & 191 & 838 & 1650 & 2015 \\
\hline 26 & 27 & 0081 & 325 & 311 & 117 & 096 & 038 & 192 & 843 & 1660 & 2030 \\
\hline
\end{tabular}

\section{References}

1. Reactor Shieldıng Information Center, Radioactive Decay Gamma-ray Spectra Compulation, Nuclear Data Tables, DLC-19, ORNL.

2. E. J. Allen, CACA-2: Revised Version of CACA-A Heavy Isotope and Fission-Product Concentration Calculational Code for Experimental Irradiation Capsules, ORNL/TM-5266(February 1976).

3. M. E. Meek and B. F. Rider, Compilation of Fission Product Yields, NEDO-12154, Vallecitos Nuclear Center (1972).

4. M. D. Goldberg, S. F. Mughabghab, B. A. Magurno, V. M. May, Neutron Cross Sections, vol. IIA, BNL-325, 2d ed., Suppl. 2 (1966).

5. M. D. Goldberg, S. F. Mughabghab, S. N. Purohit, B. A. Magurno, V. M. May, Neutron Cross Sections, vol. IIB, BNL-325, 2d ed., Suppl. 2 (1966).

6. J. R. Stehn, M. D. Goldberg, R. Wiener-Chasman, S. F. Mughabghab, B. A. Magurno, V. M. May, Neutron Cross Sections, vol. III, BNL-325, 2d ed., Suppl. 2 (1965).

7. M. E. Meek and B. F. Rider, Compilation of Fission Product Yields, NEDO-12154-1, Vallecitos Nuclear Center, General Electric Co. (1974).

8. N. E. Holden and F. W. Walker, Chart of the Nuclides, 11 th Edition, Knolls Atomic Power Laboratory, General Electric Co. April 1972.

9. H. H. Van Tuyl, ISOGEN-A Computer Code for Radiotsotope Generation Calculations, HW-83785 (1964).

10 M. J. Bell, ORIGEN, The ORNL Isotope Generation and Depletion Code, ORNL-4628 (1973).

11. H. Bateman, "The Solution of a System of Differential Equations Occurring in the Theory of Radioactive Transformations," Proc. Cambridge Philos. Soc. 15, 423 (1910). 


\section{MEASUREMENT AND INTERPRETATION OF IN-PARTICLE CARBON MONOXIDE AND KRYPTON + XENON}

Particles from the HT-12 through -15 experiments, as well as from ORNL HRB-6 and GAC P13LC4T6 experiments, were used to determine internal gas pressures. The gases are primarily carbon monoxide, krypton, and xenon and are released from the kernel into the particle void space during fission. A knowledge of the burnup dependence of the in-particle $\mathrm{Kr}+$ Xe pressures is useful both for the particle pressure-vessel design and for fission-gas availability terms for particles failing in-reactor. The $\mathrm{CO}$ pressures can be equivalent to those for $\mathrm{Kr}+\mathrm{Xe}$ and thus also affect the pressure-vessel design. More significantly, they can be used to infer the oxidation state of the fuel and fission products during burnup. This section will describe the measurement techniques, present the data, and interpret the results obtained to date in this continuing program.

\subsection{Experimental Procedures and Results}

The apparatus used for the pressure measurements has been described. ${ }^{1}$ In this apparatus a particle is equilibrated at 1000 to $2000^{\circ} \mathrm{C}$ and broken to release the gases into a known volume. The pressure is measured with a capacitance manometer, and then a titanium wire is heated to $\sim 900^{\circ} \mathrm{C}$ to getter the $\mathrm{CO}$ as well as traces of $\mathrm{CO}_{2}$, leaving the pressure of $\mathrm{Kr}+\mathrm{Xe}$ to be measured subsequently.

A primary concern of this program has been the validity of the $\mathrm{CO}$ measurements. For some time it was not conclusively demonstrated whether the $\mathrm{CO}$ measurements resulted from the real $\mathrm{CO}$ content in the particle before it was broken or from $\mathrm{CO}$ produced by rapid oxide-carbon chemical reactions after it was broken. These problems were considered in part in ref. 1. This question has apparently been favorably resolved by measurements completed on Harwell 919/8 particles obtained from Horsley ${ }^{2}$ (AERE-Harwell) and M. Wagner-Löffler (Dragon Project). These low-enriched Triso particles experienced $5.7 \%$ FIMA, with 50\% of the burnup being plutonium fissions. Particles from this batch were used to compare results of the mass spectrographic technique used at AERE-Harwell ${ }^{3}$ and at OSGAE (Austria) ${ }^{4}$ with the ORNL technique. ${ }^{1}$

The experimental results are given in Table 7.1. The ORNL results for $\mathrm{Kr}+\mathrm{Xe}$ through $1700^{\circ} \mathrm{C}$ average $2.73 \mathrm{~mm}^{3}$ (STP) and agree with the OSGAE results. The somewhat lower AERE results for $\mathrm{Kr}+$ Xe may be caused by a difference in the particle breaking method; at AERE the coatings are cracked with a micrometer to release the gas, whereas at ORNL and probably at OSGAE both the coating and the kernel are fractured, thus possibly releasing more gas from closed voids. The ORNL $\mathrm{Kr}+\mathrm{Xe}$ release at $2000^{\circ} \mathrm{C}$ is higher than the lower-temperature results probably because of $\mathrm{Kr}+\mathrm{Xe}$ diffusion from the kernel during the $2000^{\circ} \mathrm{C}$ equilibration.

The $\mathrm{CO}+\mathrm{CO}_{2}$ data at $1000^{\circ} \mathrm{C}$ lie between the AERE and OSGAE results; there does not appear to be any effect of delay time before breaking the particle nor of equilibrating for $1 \mathrm{hr}$ or for $24 \mathrm{hr}$. At $1400^{\circ} \mathrm{C}$ the ORNL results agree with the OSGAE data when the particles are broken after a delay time of either 10 or $120 \mathrm{sec}$. (At OSGAE a 10-sec delay time is used, ${ }^{2}$ whereas a 120 -sec delay is used at Harwell. ${ }^{3}$ ) On the other hand, breaking the particles immediately results in a higher amount of $\mathrm{CO}+\mathrm{CO}_{2}$ (essentially $\mathrm{CO}$ ). The difference between the delay-vs-no-delay results increases even more at 1700 and $2000^{\circ} \mathrm{C}$. It would appear that breaking the particle at the higher temperatures might release some additional $\mathrm{CO}$ as a result of post-breaking reactions; this subject is being investigated with additional HT particles. Generally, however, these data compare very well and appear to validate the measurements by the European mass spectrometric method and the ORNL capacitance manometer technique. 
Table 7.1. Gas volumes $\left(\mathrm{mm}^{3}\right.$ at $\left.\mathrm{STP}\right)$ in $919 / 8$ particles

\begin{tabular}{|c|c|c|c|c|c|c|c|}
\hline \multirow{2}{*}{ Temperature $\left({ }^{\circ} \mathrm{C}\right)$} & \multicolumn{2}{|c|}{ AERE } & \multicolumn{2}{|c|}{ OSGAE } & \multicolumn{3}{|c|}{ ORNL } \\
\hline & $\mathrm{Kr}+\mathrm{Xe}$ & $\mathrm{CO}+\mathrm{CO}_{2}$ & $\mathrm{Kr}+\mathrm{Xe}$ & $\mathrm{CO}$ & $\mathrm{Kr}+\mathrm{Xe}$ & $\mathrm{CO}+\mathrm{CO}_{2}$ & Time $^{a}$ \\
\hline 1000 & 1.89 & 0.76 & $\sim 2.8^{b}$ & 1.1 & $\begin{array}{l}2.89 \\
2.44\end{array}$ & $\begin{array}{l}0.94 \\
0.96\end{array}$ & $\begin{array}{l}24 / 0 \\
1 / 120^{c}\end{array}$ \\
\hline 1200 & 2.43 & 0.92 & $\sim 2.8^{b}$ & 1.6 & & & \\
\hline \multirow[t]{2}{*}{1400} & 2.16 & 1.21 & $\sim 2.8^{b}$ & 2.1 & $\begin{array}{l}3.05 \\
2.84\end{array}$ & $\begin{array}{l}2.88 \\
2.13\end{array}$ & $\begin{array}{l}24 / 0 \\
24 / 10\end{array}$ \\
\hline & & & & & 2.70 & 2.26 & $1 / 155$ \\
\hline \multirow[t]{4}{*}{1700} & & & & & 2.79 & 3.80 & $1 / 0$ \\
\hline & & & & & 2.87 & 2.50 & $1 / 120$ \\
\hline & & & & & 2.33 & $0.24^{d}$ & $1 / 120$ \\
\hline & & & & & 2.70 & & $1 / 120$ \\
\hline \multirow[t]{2}{*}{$2000^{e}$} & & & & & 4.07 & 9.56 & $1 / 0^{e}$ \\
\hline & & & & & 3.34 & 3.46 & $1 / 120^{e}$ \\
\hline
\end{tabular}

\footnotetext{
${ }^{a_{\text {Time }}}$ at temperature in hours/delay in seconds after heater was turned off and before breaking particle.

${ }^{b}$ Average of all AERE data times 1.3 (see ref. 2).

${ }^{c}$ Standard AERE treatment (see ref. 3).

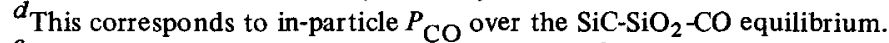

${ }^{e}$ Heated at $1400^{\circ} \mathrm{C}$ for $50 \mathrm{~min}$ and then at $2000^{\circ} \mathrm{C}$ for $10 \mathrm{~min}$.
}

Most of the present data were collected before the ORNL-AERE-OSGAE intercomparison was performed. Particles were generally broken at temperature after equilibration for 20 to $24 \mathrm{hr}$ between 1000 to $1400^{\circ} \mathrm{C}$, for 2 to $6 \mathrm{hr}$ at 1500 to $1700^{\circ} \mathrm{C}$, and for 2 to $5 \mathrm{~min}$ at $2000^{\circ} \mathrm{C}$ after 2 to $3 \mathrm{hr}$ at $1700^{\circ} \mathrm{C}$. (The intercomparison experiments show that long times at lower temperatures appear unnecessary; an hour is sufficient.) The data from the individual experiments are given in Table 7.2.

\subsection{Krypton + Xenon Release from the Kernel}

The percent release of $\mathrm{Kr}+\mathrm{Xe}$ to the particle void space is shown in Fig. 7.1. This was calculated from the observed moles of $\mathrm{Kr}+\mathrm{Xe}$ per fission and the theoretical yield. The theoretical amount of $\mathrm{Kr}+$ $\mathrm{Xe}$ was taken to be 0.335 per ${ }^{233} \mathrm{U}$ fission and 0.306 per ${ }^{235} \mathrm{U}$ fission; the yield of ${ }^{135} \mathrm{Xe}$ with a half-life of $9.17 \mathrm{hr}$ is normally included because its large cross section results in the generation of stable ${ }^{136} \mathrm{Xe}$. (Correspondingly, ${ }^{135} \mathrm{Cs}$ is not formed, and the total yield of cesium is that for ${ }^{133} \mathrm{Cs}$ and ${ }^{137} \mathrm{Cs}, \sim 12.3 \%$ for either ${ }^{233} \mathrm{U}$ or ${ }^{235} \mathrm{U}$ fission in a thermal flux.) The interpretation of the $\mathrm{Kr}+\mathrm{Xe}$ results with regard to particle failure determination will be presented in Sect. 8.2.

\subsection{Oxygen Release per Fission}

Oxygen release per fission was calculated from the experimental release of $\mathrm{CO}$ (Table 7.2) and the burnup (Table 6.5). Many of the particles in this study were considered to be failed particles, as generally evidenced by abnormally low $\mathrm{Kr}+\mathrm{Xe}$ contents as well as little or no $\mathrm{CO}$. Only the oxygen release data from intact particles were considered; the corresponding $\mathrm{CO}$ data points are underlined in Table 7.2. The oxygen release per fission is plotted in Fig. 7.2; all of these data were fitted to the equation

$$
\mathrm{O} / f=(a+b f) \exp (-Q / R T)
$$

where $\mathrm{O} / f$ is the measured moles of atomic oxygen released (as $\mathrm{CO}+\mathrm{CO}_{2}$ ) per mole of actinide that fissioned, $f$ is the fraction FIMA (not \% FIMA), $Q$ is the apparent activation energy, $R$ is the gas 
Table 7.2. Equilibration temperatures and moles of $\mathrm{CO}$ and $\mathrm{Kr}+\mathrm{Xe}$

\begin{tabular}{|c|c|c|c|c|c|c|c|c|c|c|c|c|c|}
\hline \multirow{3}{*}{$\begin{array}{l}\text { Irradiation } \\
\text { No. }\end{array}$} & \multirow{3}{*}{$\begin{array}{l}\text { Particle } \\
\text { type }^{a}\end{array}$} & \multicolumn{12}{|c|}{ Moles $\times 10^{8}$} \\
\hline & & \multicolumn{6}{|c|}{$\begin{array}{c}\mathrm{Kr}+\mathrm{Xe} \\
\text { particle number }\end{array}$} & \multicolumn{6}{|c|}{$\begin{array}{c}\text { CO } \\
\text { particle number }\end{array}$} \\
\hline & & 1 & 2 & 3 & 4 & 5 & 6 & 1 & 2 & 3 & 4 & 5 & 6 \\
\hline HT-1 2-26 & 1 & $\mathrm{ND}^{b}$ & 0.17 & 0.25 & & & & $\mathrm{ND}(1400)^{c}$ & $0.062(1410)$ & ND (2000) & & & \\
\hline HT-13-26 & 1 & 3.0 & 2.9 & 4.2 & 3.4 & 3.0 & 3.3 & $\underline{0.43}^{d}(1400)$ & $0.96(1695)$ & $0.60(2000)$ & $\underline{0.48}(1050)$ & $3.4(2000)$ & $2.1(1375)$ \\
\hline HT-14-26 & 1 & 8.3 & 9.1 & 9.7 & 8.7 & 11.0 & & $\overline{6.3}(1400)$ & $11.0(1700)$ & $23.0(2000)$ & $2.0(1080)$ & $\underline{6.1}(1100)$ & \\
\hline HT-15-26 & 1 & 13. & $\mathrm{EX}^{e}$ & 13. & 14. & & EX & $11.0(1400)$ & $E X(1100)$ & $0.81(1100)$ & $11.0(1700)$ & & $\operatorname{EX}(1100)$ \\
\hline HT-13-21 & 2 & 0.87 & 1.5 & 1.3 & 1.6 & 1.5 & 1.4 & $\underline{0.11}(1100)$ & $0.18(1115)$ & $0.29(2000)$ & $1.7(1700)$ & $\underline{0.82}(1700)$ & $\underline{0.45}(1400)$ \\
\hline Second set & 2 & 1.8 & 1.4 & 1.3 & 0.68 & & & $1.1(1700)$ & $1.4(2000)$ & $\overline{0.53}(1550)$ & $\overline{\mathrm{ND}}(1850)$ & & \\
\hline HT-14-21 & 2 & & ND & 4.2 & 0.40 & ND & & & ND (1100) & $1.0(1700)$ & ND (1400) & ND (1700) & \\
\hline Second set & 2 & EX & EX & 4.4 & 4.2 & & & $\operatorname{EX}(1700)$ & $\operatorname{EX~(1700)~}$ & ND (1100) & $2.3(1700)$ & & \\
\hline HT-14-13 & 1 & EX & 0.21 & 0.43 & 5.5 & EX & 4.1 & $\operatorname{EX}(1400)$ & $0.28(1700)$ & ND (1100) & $6.4(1430)$ & EX (1100) & ND (1100) \\
\hline HT-15-13 & 1 & 0.19 & & $\mathrm{EX}$ & 1.1 & & & $0.27(1700)$ & & EX $(1600)$ & $0.39(1700)$ & & \\
\hline HT-13-8 & 2 & 0.13 & 0.29 & 0.14 & 0.14 & 0.07 & 0.10 & $\underline{0.15}(1100)$ & $0.35(1750)$ & $\underline{0.14}(1390)$ & $\underline{0.35}(1550)$ & $\underline{0.17}(1250)$ & $1.25(1400)$ \\
\hline HT-14-8 & 2 & & & & 0.34 & ND & 0.31 & & & & $0.45(1650)$ & $\mathrm{ND}(1850)$ & $0.31(1400)$ \\
\hline HT-15-29 & 3 & 0.45 & 0.60 & 4.0 & 0.13 & & 0.20 & $0.062(1400)$ & ND (1665) & $0.47(1400)$ & $1.1(2000)$ & & $0.088(1100)$ \\
\hline HT-13-29 & 3 & 1.02 & 1.32 & 1.18 & 0.96 & 1.16 & 1.09 & $1.50(2000)$ & $0.15(1400)$ & $0.81(1700)$ & ND $(1100)$ & $0.02(1080)$ & $0.98(1400)$ \\
\hline HT-14-29 & 3 & EX & EX & ND & ND & 0.44 & 0.21 & EX $(1400)$ & $\mathrm{EX}(1250)$ & ND $(1400)$ & ND (1090) & $0.15(1375)$ & ND (1660) \\
\hline HRB6-C1-1 & 4 & 5.1 & 4.8 & 4.7 & 4.6 & 5.2 & 4.6 & $9.3(2000)$ & $3.2(1700)$ & $3.6(1430)$ & $\underline{6.6}(1550)$ & $\underline{1.7}(1225)$ & $\underline{2.0}(1090)$ \\
\hline HRB6-1C-2 & 4 & 4.9 & 4.8 & 4.9 & 5.1 & 6.3 & 5.0 & $6.7(1700)$ & $3.7(1400)$ & $1.3(1100)$ & $8.1(2000)$ & $4.6(1400)$ & $\underline{1.6}(1100)$ \\
\hline P13LC4T6-10 & 5 & 0.46 & 1.2 & 0.50 & 1.1 & & & $0.70(1700)$ & $0.078(1215)$ & $0.35(1550)$ & $1.5(2000)$ & & \\
\hline P13LC4T6-11 & 5 & 0.61 & 1.6 & 0.47 & 0.31 & & & $1.1(1800)$ & $1.1(1700)$ & $0.065(1100)$ & $0.12(1400)$ & & \\
\hline
\end{tabular}

${ }^{a}$ Kernel radius/buffer thickness, in $\mu \mathrm{m}: 1,254 / 79.4 ; 2,201 / 24.6 ; 3,201 / 32.3 ; 4,175 / 100 ; 5,260 / 69$.

${ }^{b} \mathrm{ND}=$ none detected.

${ }^{c}$ Numbers in parentheses indicate temperature in degrees centigrade.

${ }^{d}$ Underlined values were used for the least-squares fit of Eq. 1 of Sect. 7.

${ }^{e} \mathrm{EX}=$ particle exploded during observation through optical pyrometer.

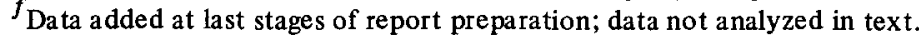


ORNL DWG 75-15030

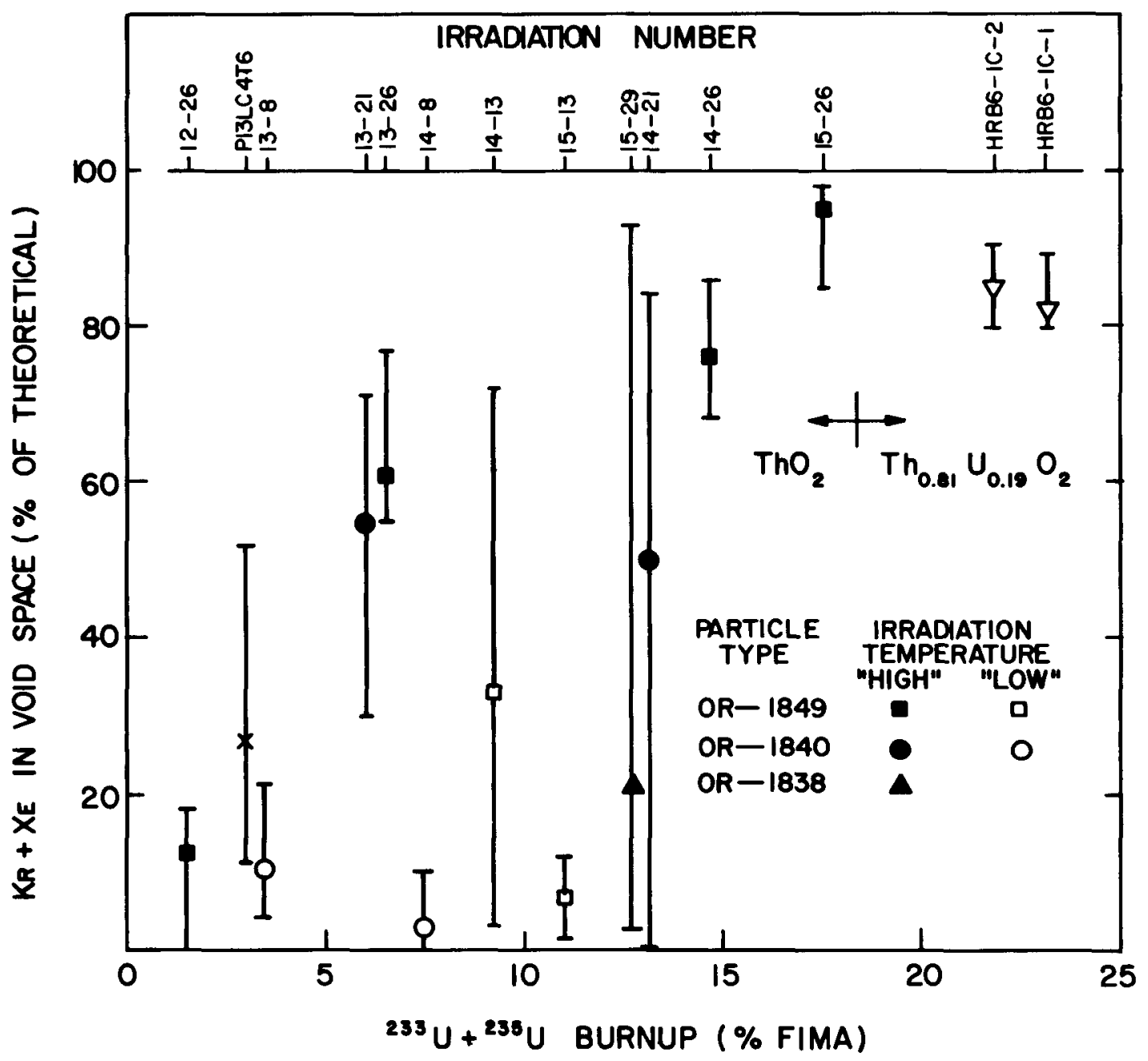

Fig. 7.1. Percent of theoretical $\mathbf{K r}+$ Xe released by breaking individual irradiation particles. The open or closed symbol is the average value, while the vertical bars represent the data range $\mathrm{Th} 1 \mathrm{Kr}+\mathrm{Xe}$ is assumed to exist primarily in the vold space of the buffer layer

constant, and $T$ is the temperature in ${ }^{\circ} \mathrm{K}$. The coefficients $a, b$, and $Q$ were determined from an application of the least-squares theorem simultaneously to all the data to give $a=0.234, b=26.5$, and $Q=10,900 \mathrm{cal} / \mathrm{mole}$. These coefficients are applicable over the range $0.03 \leqslant f \leqslant 0.22$ and $1050 \leqslant T \leqslant 2000^{\circ} \mathrm{C}$.

In-particle pressures of $\mathrm{CO}+\mathrm{CO}_{2}$ were calculated from the observed $\mathrm{CO}$ release by assuming that the ideal-gas law was valid at all pressures and that the avalable vold space was $50 \%$ of the buffer-layer volume and $3 \%$ of the kernel volume. The chemical potential of oxygen $\left(\Delta \bar{F}_{\mathrm{O}_{2}}^{0}=R T \ln P_{\mathrm{O}_{2}}\right.$ for the reaction type $\mathrm{M}+\mathrm{O}_{2} \rightarrow \mathrm{MO}_{2}-$ henceforth called oxygen potential) was also calculated by assuming equilibrium in the $\mathrm{C}-\mathrm{CO}-\mathrm{CO}_{2}-\mathrm{O}_{2}$ system within the particle. These calculated results are given in Fig. 7.3 .

\subsection{Review of Oxide Fuel Chemistry}

Interpretation of the observed oxygen release will be based on the FIMA-dependent composition of the particles and on the thermodynamic information that appears in the literature. The relative 
ORNL DWG. $75-4980 R 2$

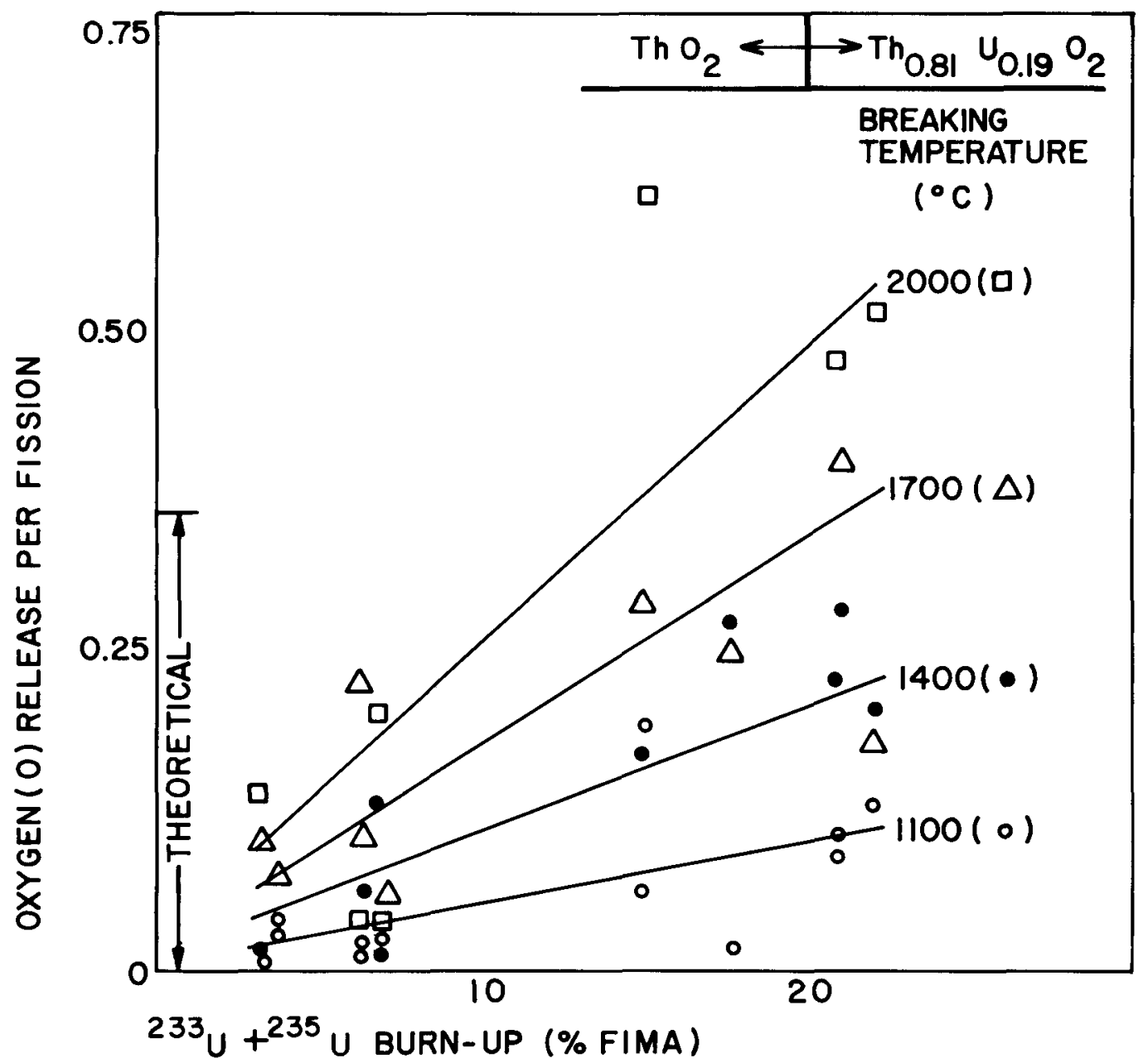

Fig. 7.2. Experimental atomic oxygen release per fission in $\mathrm{ThO}_{2}$ and $\mathrm{Th}_{0.81} \mathrm{U}_{0.19} \mathrm{O}_{2}$ particles as a function of ${ }^{233} \mathrm{U}$ plus ${ }^{235} \mathrm{U}$ burnup and equilibration temperature. The four lines are from the least-squares fit of Eq. (7.1).

concentrations of all metals that may form oxides under conditions that may exist in a $\mathrm{ThO}_{2}$ particle appear in Fig. 7.4. The total burnup and concentrations of ${ }^{232} \mathrm{Th},{ }^{233} \mathrm{~Pa}$, and ${ }^{233-236} \mathrm{U}$ are calculated as a function of exposure time at the HFIR horizontal midplane. ${ }^{5}$ The concentrations of fission products two years after reactor discharge were calculated from the burnup and from the Meek and $\operatorname{Rider}^{6}$ fission product yields for ${ }^{233} \mathrm{U}$ fission. Minor variations between ${ }^{233} \mathrm{U}$ and ${ }^{235} \mathrm{U}$ fission product yields are not significant to the analysis to be given here.

The majority of the available thermodynamic information on the chemical potential of oxygen for the actinide-fission product oxide systems is given in Fig. 7.5. The protactinium oxidizes in the range $\mathrm{PaO}_{2}$ to $\mathrm{PaO}_{2.5}$, and the information in Fig. 7.5 is from Knoch and Schieferdecker. ${ }^{7}$ The protactinium concentrations of interest here also exist in $\mathrm{ThO}_{2}$ solid solutions at oxidation states ranging from $\mathrm{PaO}_{2}$ to $\mathrm{PaO}_{2.5}{ }^{8}$ The $\mathrm{UO}_{2 \pm x}$ system also exists in solid solution with $\mathrm{ThO}_{2}$; hyperstoichiometry in the $\mathrm{ThO}_{2}$ $\mathrm{UO}_{2+x}$ system appears to occur at the same oxygen potential as in the pure $\mathrm{UO}_{2+x}$ system, ${ }^{9-11}$ but values of $x \geqslant 0.001$ in the $\mathrm{UO}_{2+x}$ system do not occur at oxygen potentials more negative than $-70 \mathrm{kcal} / \mathrm{mole}$. Thus, the Th-U-Pa-O system appears to be a complete solid solution at the concentrations and oxygen potentials of interest here, with the protactinium at this point of the analysis being the only actinide above a $4+$ valence state. 


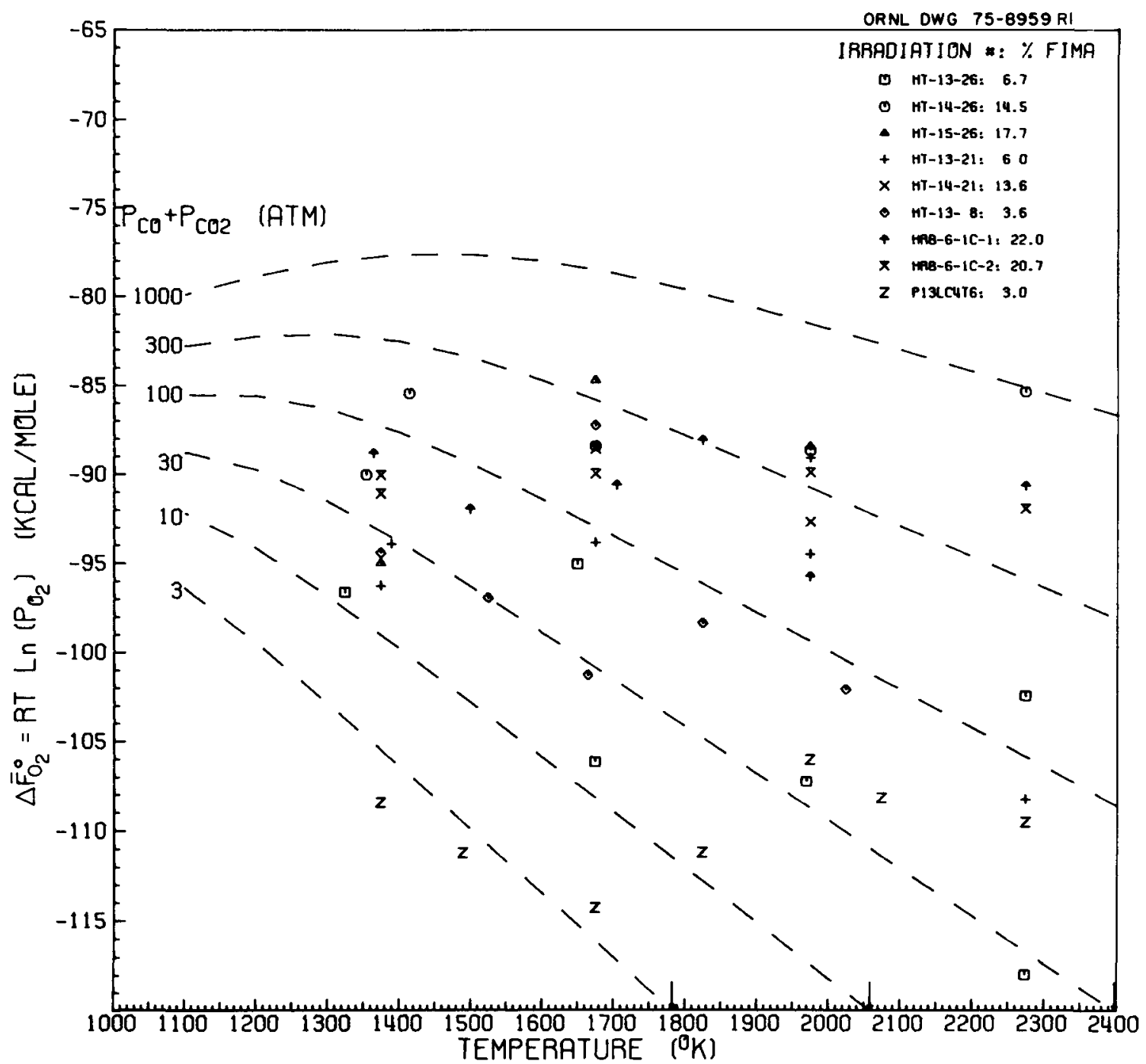

Fig. 7.3. Experimentally derived chemical potential of oxygen $\left(\Delta \bar{F}_{\mathrm{O}_{2}}^{0}\right)$ vs temperature and ${ }^{233} \mathrm{U}$ plus ${ }^{235} \mathrm{U}$ burnup in $\mathrm{ThO}_{2}$ and $\mathrm{Th}_{081} \mathrm{U}_{0}{ }_{19} \mathrm{O}_{2}$ particles. Also indicated is the in-particle value of $P_{\mathrm{CO}}+P_{\mathrm{CO}_{2}}$ in atmospheres 
ORNL OWG $76-205 \mathrm{RI}$

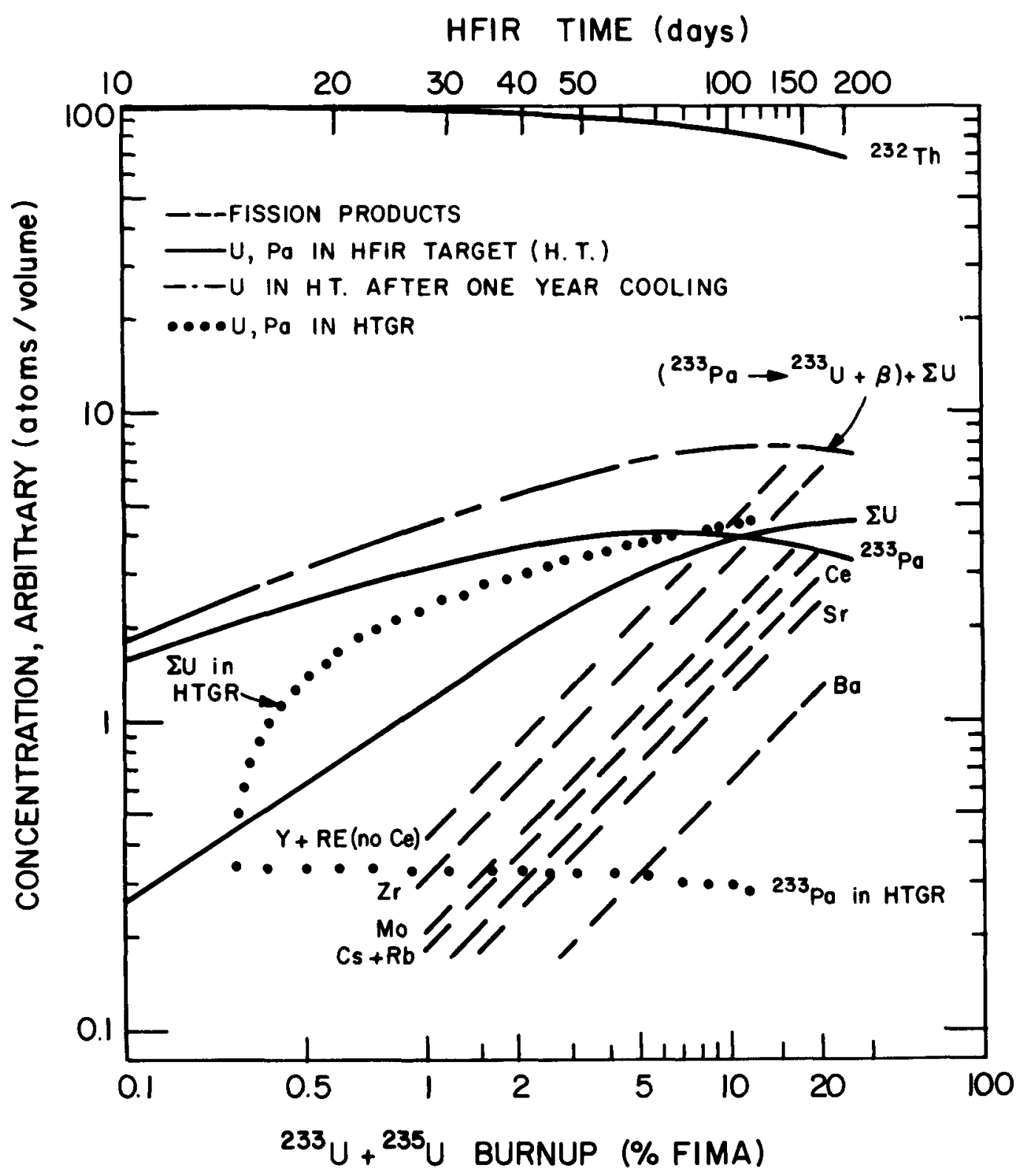

Fig. 7.4. Time-dependent concentrations of actinides and fission products in the HFIR target region at the fission rate conditions shown in Fig. 6.1. Fission product yields are for ${ }^{233} \mathrm{U}$ fission in a thermal flux and also approximate those for ${ }^{235} \mathrm{U}$ fission Cerium is shown separately from the other rare-earth elements for thermodynamic reasons Also shown are total out-of-reactor $\mathrm{U}$ concentration after complete 27 -day ${ }^{23}{ }^{2} \mathrm{~Pa}$ decay and the $\mathrm{Pa}$ and $\mathrm{U}$ concentrations in an HTGR 
ORNL DWG $75-15033$

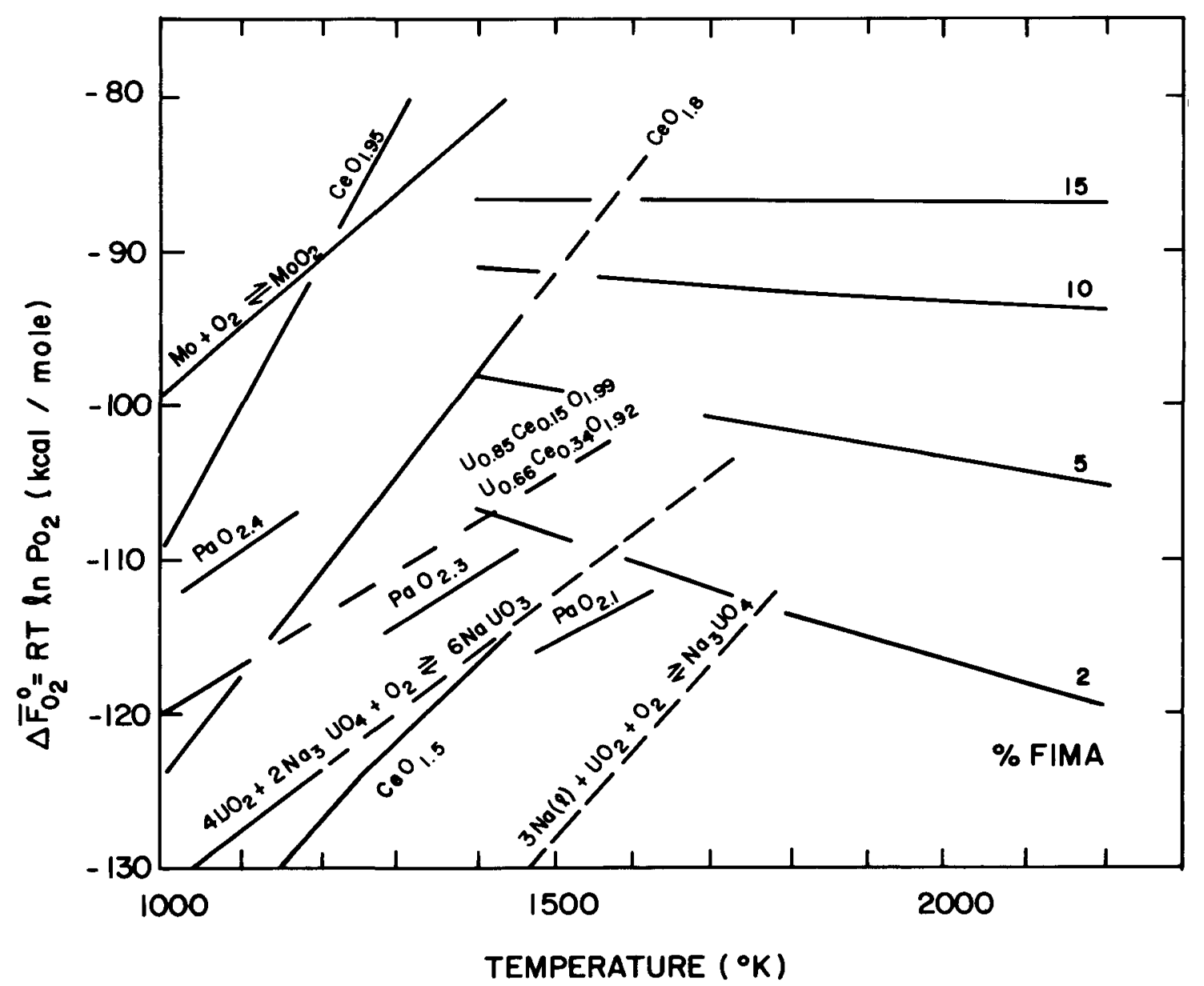

Fig. 7.5. Literature values of $\Delta \bar{F}_{\mathrm{O}}^{0}$ for several actinide, fission product, and $\mathrm{Na}$ systems. The Cs-Rb-U-O systems are believed to behave nearly identically to the Na-U-O system; dashed lines are the writer's extrapolations for equilibria involving the solid compounds. Also shown are the $\Delta \bar{F}_{\mathrm{O}_{2}}^{0}$ values equivalent to those for out-of-reactor $\mathrm{CO}$ pressures calculated from Eq. (7.1) for a $\mathrm{ThO}_{2}$ particle with a void/kernel ratio of 0.5 .

However, an interaction of uranium with yttrium and rare-earth (RE) elements that promote the uranium valence to $>4$ is generally recognized to occur. It is widely known that individual oxides of $\mathrm{RE}$ elements and yttrium exist in extensive $\mathrm{CaF}_{2}$-type solid solutions with $\mathrm{UO}_{2}$ and $\mathrm{ThO}_{2}$ at $\mathrm{HTGR}$ temperatures; these solutions contain as much as $\sim 75$ mole $\%$ of (RE) $\mathrm{O}_{1.5}$. Similarly, $\mathrm{CaF}_{2}$-type solid solutions of $(\mathrm{RE}) \mathrm{O}_{1.5}-\mathrm{Pa}_{2} \mathrm{O}_{5}$ are reported. ${ }^{12}$ Thus, at this point we now have an oxide solid solution containing all the actinide, yttrium, and RE elements. In this solid solution uranium exists at a valence higher than $4+$ at oxygen potentials significantly more negative than those in the pure $\mathrm{UO}_{2+x}$ system. Markin and Crouch ${ }^{13}$ have briefly investigated the U-Ce-O system at 800 to $950^{\circ} \mathrm{C}$, and some of their data are plotted in Fig. 7.5; the extrapolation of $\Delta \bar{F}_{\mathrm{O}_{2}}^{0}$ is based on $\Delta \bar{S}_{\mathrm{O}_{2}}^{0} \approx-30 \mathrm{cal} \mathrm{mole}^{-1}\left({ }^{\circ} \mathrm{K}\right)^{-1}$. A significant and extensive study of the U-Nd-O system at $850^{\circ} \mathrm{C}$ has been reported by Wadier, ${ }^{14}$ and part of his results are reproduced in Fig. 7.6. (Neodymium is the most abundant RE fission product.) Wadier ${ }^{14}$ also reported $\Delta \bar{S}_{\mathrm{O}_{2}}^{0} \approx-50 \mathrm{cal} \mathrm{mole}^{-1}\left({ }^{\circ} \mathrm{K}\right)^{-1}$ for $\mathrm{O} /(\mathrm{Nd}+\mathrm{U})$ ratios of interest here. In addition, the $\mathrm{O} / \mathrm{U}$ ratios shown in Fig. 7.6 were calculated by assuming a constant neodymium valence of $3+$; this approach demonstrates the significant effect of the U-RE interaction on promoting the uranium valence 
- Nd, WADIER (1973)

+ Eu, LEITNAKER (1974)

$\times$ La, STADLBAUER ET AL. (1974)

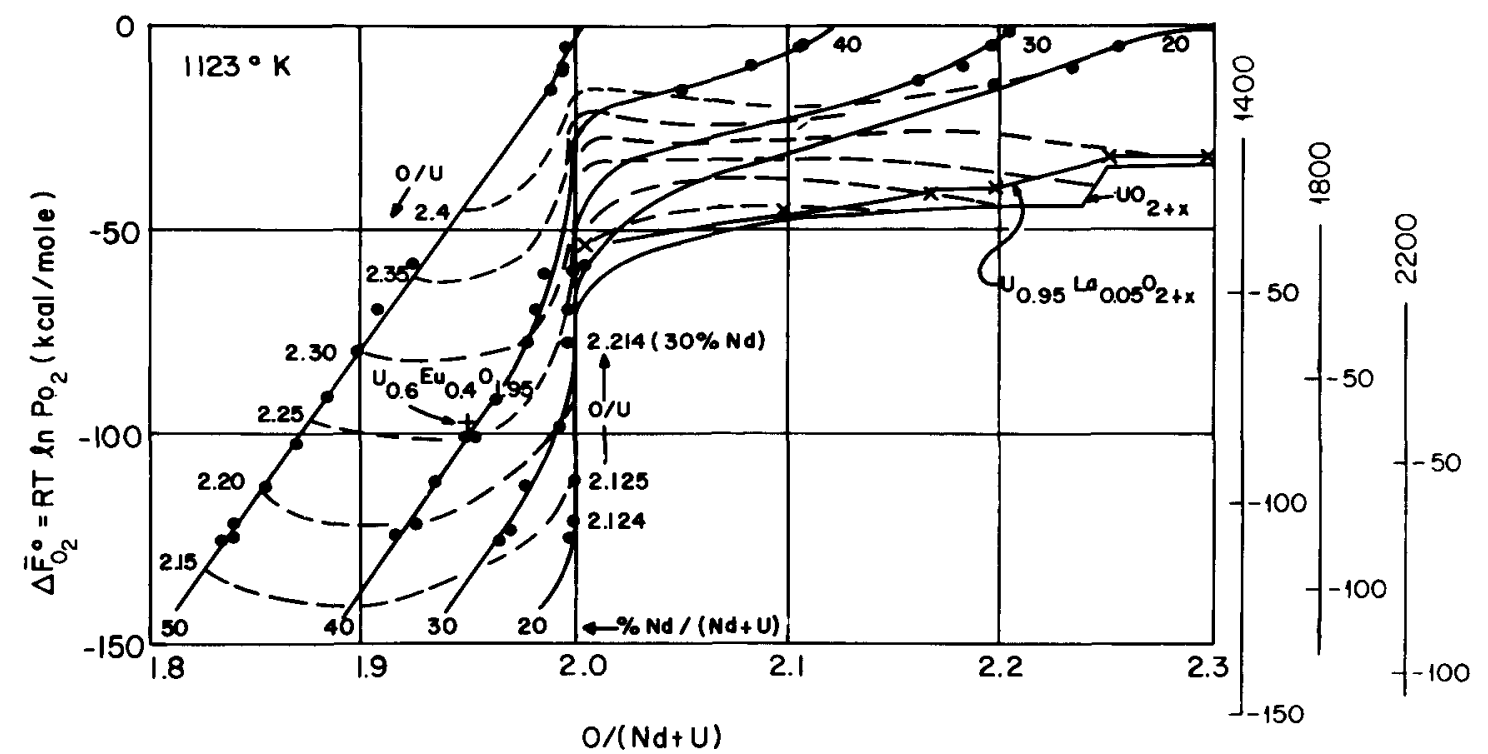

Fig. 7.6. Literature values of $\Delta \bar{F}_{\mathrm{O}_{2}}^{0}$ at $1123^{\circ} \mathrm{K}$ for systems involving $\mathrm{U}, \mathrm{O}$, and the RE elements $\mathrm{Nd}$, Eu, and La. Also shown are $\mathrm{O} / \mathrm{U}$ values calculated by the writer for a constant $\mathrm{RE}$ valence of $3+$ as well as $\Delta \bar{F}_{\mathrm{O}_{2}}^{0}$ values at 1400,1800 , and $2200^{\circ} \mathrm{K}$ for an assumed $\Delta S_{\mathrm{O}_{2}}^{0}=-50 \mathrm{cal} \mathrm{mole}^{-1}\left({ }^{\circ} \mathrm{K}\right)^{-1}$.

above 4+. Leitnaker ${ }^{15}$ has reported the existence of $\mathrm{U}_{0.6} \mathrm{Eu}_{0.4} \mathrm{O}_{1.95}$ at $900^{\circ} \mathrm{C}$ and at a $\mathrm{CO} / \mathrm{CO}_{2}$ ratio of 10 ; these data are shown in Fig. 7.6 and coincide exactly with Wadier's results. Stadlbauer et al. ${ }^{16}$ have investigated the $\mathrm{U}_{0.95} \mathrm{La}_{0.05} \mathrm{O}_{2+x}$ system from 600 to $1000^{\circ} \mathrm{C}$, and their results at $850^{\circ} \mathrm{C}$ are also shown in Fig. 7.6. Hagemark and $\mathrm{Broli}^{17}$ have made similar investigations in the U-La-O and U-Y-O systems at $1000 \leqslant T \leqslant 1400^{\circ} \mathrm{C}$ and up to $5 \%$ of yttrium or lanthanum. Their results agree closely with those of Stadlbauer et al. ${ }^{16}$ No other oxygen potential data for any actinide-RE-O system have appeared in the literature-a rather abominable situation when one considers the importance of precise knowledge of oxygen release data upon fuel-containment interactions in the HTGR oxide fuel system as well as in the LWR and LMFBR oxide fuel systems. It is also clear that the data for ternary systems discussed above will be further influenced by mutual interactions between $\mathrm{U}, \mathrm{Pa}, \mathrm{Y}, \mathrm{La}$, and the $\mathrm{RE}$ elements, particularly cerium. Cerium is the only RE element that can be oxidized above $3+$ valence at HTGR particle conditions; comparison of the U-Ce-O and U-Nd-O data indicates a quite dissimilar effect on the uranium valence.

Now consider the fission products $\mathrm{Zr}, \mathrm{Sr}, \mathrm{Ba}$, and $\mathrm{Mo}$. The zirconium exists as the dioxide, and the strontium and barium exist as the monoxide. Although phase diagrams indicate that the three phases present should be actinide oxide (with most of the $\mathrm{Y}$, La, and $\mathrm{RE}$ in solution) plus $\mathrm{ZrO}_{2}$ (RE-stabilized cubic structure?) plus the perovskite-type compound $\mathrm{ZrO}_{2} \cdot \mathrm{Ba}_{1-z} \mathrm{Sr}_{z} \mathrm{O}$, strontium and barium are reported to exist simultaneously in association with zirconium as well as separately in irradiated fuels. ${ }^{18-21}$ This separation of strontium or barium brings up the possibility of interaction with molybdenum to form ( $\mathrm{Sr}, \mathrm{Ba}$ )-Mo-O compounds. McCarthy and Gooden ${ }^{22}$ have published the Sr-Mo$\mathrm{O}$ phase diagram at $1200^{\circ} \mathrm{C}$, and thermodynamic data for this and the analogous $\mathrm{Ba}-\mathrm{W}-\mathrm{O}$ system ${ }^{23}$ 
would indicate that the compound $3 \mathrm{Sr}_{1-z} \mathrm{Ba}_{z} \mathrm{O} \cdot \mathrm{MoO}_{3}$ may exist in an equilibrium of the type $3 \mathrm{SrO}+\mathrm{Mo}$ $+1.5 \mathrm{O}_{2} \rightarrow 3 \mathrm{SrO} \cdot \mathrm{MoO}_{3}$ at oxygen potentials of interest here. However, such an $\mathrm{Sr}-\mathrm{Ba}-\mathrm{Mo}$ association has not been reported from microprobe analysis of irradiated fuels. It appears that the reason for this is that the reaction $3 \mathrm{SrO} \cdot \mathrm{MoO}_{3}+3 \mathrm{ZrO}_{2} \rightarrow 3\left[\mathrm{SrO} \cdot \mathrm{ZrO}_{2}\right]+\mathrm{MoO}_{2}+1 / 2 \mathrm{O}_{2}$ would occur at oxygen potentials found in HTGR particles. We further assume that molybdenum oxidizes only at the $\mathrm{MoO}_{2}-\mathrm{Mo}_{\mathrm{o}} \mathrm{O}_{2}$ equilibrium shown in Fig. 7.5.

Consider, finally, cesium and rubidium in the presence of $\mathrm{UO}_{2}$. Here, information on the cesium and rubidium systems will generally need to be deduced from analogous sodium systems. Battles et al. ${ }^{24}$ and Blackburn ${ }^{25}$ have published the equilibrium diagram shown in Fig. 7.7-the oxygen potential values at $1200^{\circ} \mathrm{K}$ for the equilibrium $\mathrm{UO}_{2}+3 \mathrm{Na}(1)+\mathrm{O}_{2} \rightarrow \mathrm{Na}_{3} \mathrm{UO}_{4}, \Delta \bar{H}_{f, 298}^{0}=-477.7 \mathrm{kcal} / \mathrm{mole}$, and $\bar{S}_{298}^{0}=47.4 \mathrm{cal} \mathrm{mole}^{-1}\left({ }^{\circ} \mathrm{K}\right)^{-1}$. Readily available $\bar{S}_{298}^{0}$ data for the other three components for this equilibrium lead to $\Delta \bar{S}_{298}^{0}=-57 \mathrm{cal} \mathrm{mol}^{-1}\left({ }^{\circ} \mathrm{K}\right)^{-1}$, used to extrapolate from Blackburn's $1200^{\circ} \mathrm{K}$ value in Fig. 7.5. Blackburn ${ }^{25}$ next indicated the equilibrium $4 \mathrm{UO}_{2}+2 \mathrm{Na}_{3} \mathrm{UO}_{4}+\mathrm{O}_{2} \rightarrow 6 \mathrm{NaUO}_{3}$ at $1200^{\circ} \mathrm{K}$. O'Hare and Hoekstra ${ }^{26}$ estimate $\bar{S}_{298}^{0}=30.1 \mathrm{cal} \mathrm{mole}^{-1}\left({ }^{\circ} \mathrm{K}\right)^{-1}$ for $\mathrm{NaUO}_{3}$, which leads to $\Delta \bar{S}_{298}^{0}=-38.2$ cal mole ${ }^{-1}\left({ }^{\circ} \mathrm{K}\right)^{-1}$ for this equilibrium and the extrapolated behavior shown in Fig. 7.5. At more positive oxygen potentials, $\mathrm{UO}_{2}$ and $\mathrm{NaUO}_{3}$ are the stable phases for all $\mathrm{HT}$ particle conditions. It should be noted, however, that the melting and decomposition temperatures of these $\mathrm{Na}-\mathrm{U}-\mathrm{O}$ compounds are not known, and the extrapolations are only for the solid phases.

ORNL DWG 75-15031

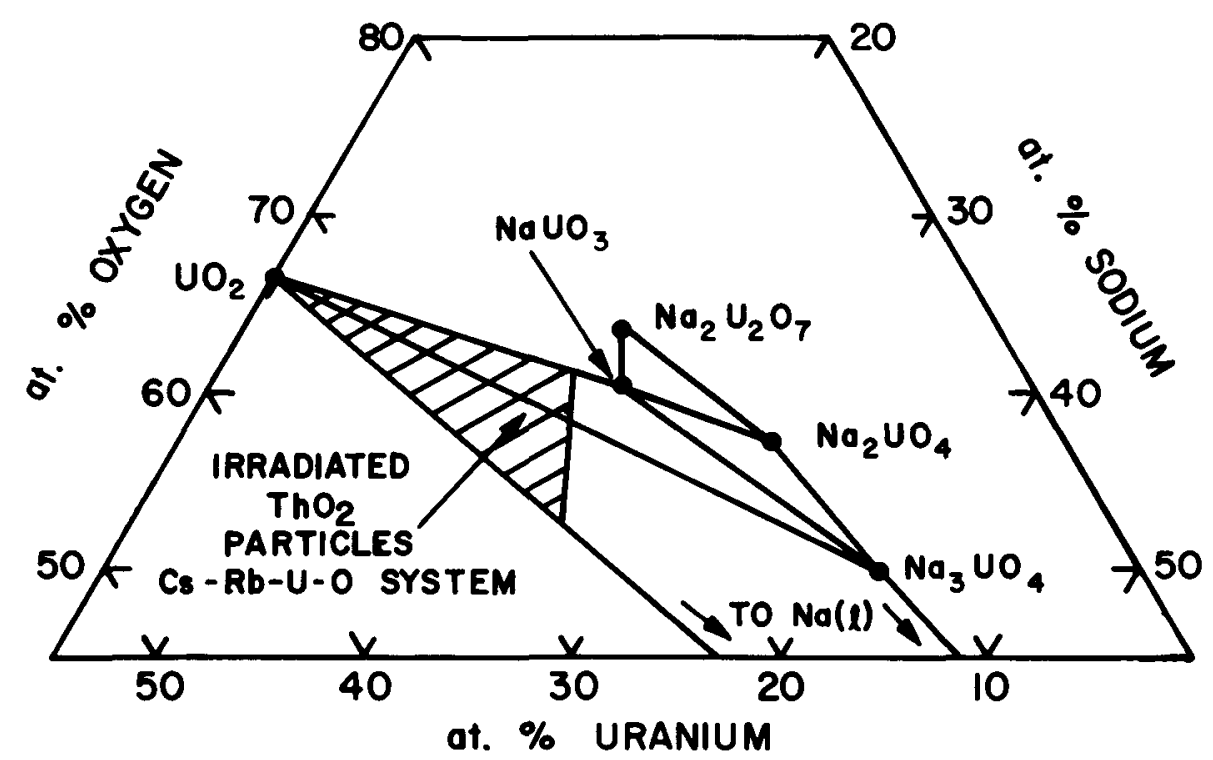

\section{$\frac{\text { BLACKBURN ( } 1974)}{B 00^{\circ} \mathrm{C}}$ $800^{\circ} \mathrm{C}$}

Fig. 7.7. The Na-U-O equilibrium diagram at $800^{\circ} \mathrm{C}$. Also shown as the shaded area is the composition range for the $(\mathrm{Cs}+\mathrm{Rb})-\mathrm{U}-\mathrm{O}$ system existing in the coated particles studied here. 
The comparison of the Na-U-O and Cs-U-O systems assumes that analogous phase equilibria exist. The values of $\Delta \vec{F}_{T}^{0}$ for equilibria in the Cs-U-O system can be approximated very closely by use of the equation $\Delta \vec{F}_{T}^{0}=\Delta \bar{H}_{298}^{0}-T \Delta \bar{S}_{298}^{0}$, and, in fact, $\Delta \bar{S}_{298}^{0}$ can be assumed to be constant for the analogous CsU-O equilibria. Therefore, the only difference in $\Delta \bar{F}_{T}^{0}$ for the two systems will originate in $\Delta \bar{H}_{f, 298}^{0}$ differences. The only direct comparison available is for $\mathrm{M}_{2} \mathrm{UO}_{4}$; for $\mathrm{M}=\mathrm{Na}, \Delta \bar{H}_{f, 298}^{0}=-445.6$ $\mathrm{kcal} / \mathrm{mole},{ }^{27}$ for $\mathrm{M}=\mathrm{Cs}, \Delta \bar{H}_{f, 298}^{0}=-453.5 \mathrm{kcal} /$ mole. $^{28}$ Readily available $\Delta \bar{H}_{f, 298}^{0}$ data $^{29}$ for $\mathrm{M}_{2} \mathrm{O}, \mathrm{MBr}$, $\mathrm{M}_{2} \mathrm{CO}_{3}, \mathrm{MCl}, \mathrm{MClO}_{4}, \mathrm{MI}, \mathrm{MNO}_{3}, \mathrm{MOH}, \mathrm{M}_{2} \mathrm{~S}$, and $\mathrm{M}_{2} \mathrm{SO}_{4}$ indicate that $\Delta \bar{H}_{f, 298}^{0}$ for the cesium compound averages $4 \mathrm{kcal} /$ mole more negative than that for the sodium. Thus, the oxygen potentials for the Cs-U-O system may be slightly more negative than those shown for the Na-U-O system in Fig. 7.5. The rubidium system will be assumed to behave identically to the cesium system. Interactions of the Cs-Th-O system have not been studied and thus will not be considered here; only a limited amount of information on the alkali-metal- $\mathrm{Pa}-\mathrm{O}$ systems exists, and at oxygen potentials more positive than those of interest here. Having performed this exercise, we will assume that cesium and rubidium oxides are not stable at temperatures used in the measurements of gas pressures on particles from HT- 12 through -15 . This assumption is based primarily on the lack of evidence of the stability of these compounds above $1200^{\circ} \mathrm{K}$. Conversely, they should be present below $1200^{\circ} \mathrm{K}$ and not only combine cesium into a compound, with a significantly lower overpressure of $\mathrm{Cs}$, but also they would combine with oxygen and lower the oxygen release per fission. At a $\mathrm{Cs}+\mathrm{Rb}$ yield for ${ }^{233} \mathrm{U}$ of 0.187 per fission, this additional combined oxygen would be $0.126 \mathrm{O} / f$ as $\left(\mathrm{Rb}_{1-2} \mathrm{Cs}_{z}\right)_{3} \mathrm{UO}_{4}$ and $0.187 \mathrm{O} / f$ as $\mathrm{Rb}_{1-z} \mathrm{Cs}_{z} \mathrm{UO}_{3}$.

\subsection{Interpretation of Oxygen Release Data}

At this point a comparison is possible of the measured and theoretical oxygen release per fission. First, it is recognized that the $27-$ day ${ }^{233} \mathrm{~Pa}$ had decayed to ${ }^{233} \mathrm{U}$ by the time the gas pressure measurements were made on the HT particles. The total out-of-reactor uranium concentration is thus the sum of the in-reactor ${ }^{233} \mathrm{~Pa}$ and uranium, as shown in Fig. 7.4. Second, Eq. (7.1) was used to calculate the in-particle oxygen potential values shown in Fig. 7.5 for a particle having a void volume equal to onehalf of the kernel volume. The calculations at 5\% FIMA in Table 7.3 can then be considered. The ratios of $(\mathrm{Y}+\mathrm{RE}-\mathrm{Ce}) / \mathrm{U}, \mathrm{Ce} / \mathrm{U}$, and $\mathrm{U} /$ fission were obtained from Fig. 7.4; here cerium is considered separately from the rest of the RE elements so that the data for the Ce-U-O system in Fig. 7.5 can be used. The oxygen potentials in Table 7.3 at 5\% FIMA and at 1400,1800 , and $2200^{\circ} \mathrm{K}$ were obtained from Fig. 7.5. The maximum theoretical oxygen release per fission for ${ }^{233} \mathrm{U}$ fission in a thermal flux has been given as $0.264 \mathrm{O} / f$ (see ref. 11, Table $\mathrm{I}$ ); to this is added 0.07 for cerium existing as $\mathrm{CeO}_{1.5}$ instead of the $\mathrm{CeO}_{2}$ assumed in ref. 11 . $\left({ }^{144} \mathrm{Ce}\right.$ has decayed to insignificance; only ${ }^{140} \mathrm{Ce}$ and ${ }^{142} \mathrm{Ce}$ are chemically significant.) The combined oxygen resulting from the estimated temperature dependence of hyperstoichiometry, $y$, in the $\mathrm{CeO}_{1.5+y}-\mathrm{UO}_{2}$ system (Fig. 7.5) is calculated in Table 7.3. (Assigning all the hyperstoichiometry to a change in cerium valence is used as a calculational convenience; the thermodynamic behavior probably involves hyperstoichiometry in both $\mathrm{CeO}_{1.5+y}$ and $\mathrm{UO}_{2+x}$.) Finally, the hyperstoichiometry in $\mathrm{UO}_{2+x}$ as a result of the $\mathrm{U}-(\mathrm{Y}+\mathrm{RE}$, less $\mathrm{Ce})$ interaction is obtained from Fig. 7.6 for the given oxygen potential and composition. The calculated $\mathrm{O} / f$ is thus 0.334 minus the combined hyperstoichiometric oxygen; this is compared with the measured $\mathrm{O} / \mathrm{f}$ on the bottom two lines of Table 7.3. Similar calculations were made at 15\% FIMA (Table 7.4). In both cases the agreement is reasonable. Other factors contributing to the observed disagreement, which are to be assessed in our ongoing studies, are effects of possible $\mathrm{Sr}+\mathrm{Ba}$ loss from the kernel, and the errors in $Q$, Eq. (7.1), mentioned earlier as possibly resulting from errors in the 1700 to $2000^{\circ} \mathrm{C}$ experimental determinations of $\mathrm{CO}$ contents. One must also realize that the thermodynamic behavior of the Y-RE-U-O systems was extrapolated by as much as $1075^{\circ} \mathrm{C}$ on the basis of $\Delta \bar{S}_{02}^{0}$ values that are not well established. 
Table 7.3. Out-of-reactor (HFIR) oxygen release per fission at 5\% FIMA

\begin{tabular}{|c|c|c|c|}
\hline \multirow{2}{*}{\multicolumn{4}{|c|}{$\begin{array}{l}(\mathrm{Y}+\mathrm{RE}-\mathrm{Ce}) / \mathrm{U}=2.1 / 7.0(77 \% \mathrm{U}) \\
\mathrm{Ce} / \mathrm{U}=0.9 / 7.0(12.5 \% \mathrm{Ce}) \\
\mathrm{U} \text { present } / \text { fission }=7.0 / 5.0=1.40 \mathrm{U} / f\end{array}$}} \\
\hline & & & \\
\hline Temperature $\left({ }^{\circ} \mathrm{K}\right)$ & 1400 & 1800 & 2200 \\
\hline$R T \ln P_{\mathrm{O}_{2}}(\mathrm{kcal} / \mathrm{mole})^{a}$ & -97 & -102 & -105 \\
\hline Maximum theoretical $\mathrm{O} / f$ & 0.334 & 0.334 & 0.334 \\
\hline \multicolumn{4}{|l|}{$\begin{array}{l}\text { Less combined oxygen } \\
\quad y \text { moles } \mathrm{O} \text { as } \mathrm{CeO}_{1.5+y} \text { at: }\end{array}$} \\
\hline$y=0.5 ; 0.5 \times \frac{0.9 \mathrm{Ce}}{5 \text { fissions }}$ & 0.09 & & \\
\hline $\begin{array}{l}y=0.3 \\
y=0.1\end{array}$ & & 0.054 & 0.018 \\
\hline $\begin{array}{l}x \text { moles } \mathrm{O} \text { as } \mathrm{UO}_{2+x} \text { at: } \\
\quad x=0.14 ; 0.14 \times 1.40 \\
x=0.12\end{array}$ & 0.196 & 0.168 & \\
\hline$x=0.10$ & & & 0.14 \\
\hline Calculated $\mathrm{O} / f$ released & 0.039 & 0.112 & 0.176 \\
\hline Actual $\mathrm{O} / f^{b}$ & 0.031 & 0.074 & 0.129 \\
\hline
\end{tabular}

${ }^{a}$ See Fig. 7.5.

${ }^{b}$ See Eq. (7.1).

Table 7.4. Out-of-reactor (HFIR) oxygen release per fission at $15 \%$ FIMA

$(\mathrm{Y}+\mathrm{RE}-\mathrm{Ce}) / \mathrm{U}=6.2 / 7.8(56 \% \mathrm{U})$

$\mathrm{Ce} / \mathrm{U}=2.6 / 7.8(25 \% \mathrm{Ce})$

$\mathrm{U}$ present $/$ fission $=7.8 / 1.5=0.52 \mathrm{U} / f$

\begin{tabular}{|c|c|c|c|}
\hline Temperature $\left({ }^{\circ} \mathrm{K}\right)$ & 1400 & 1800 & 2200 \\
\hline$R T \ln P_{\mathrm{O}_{2}}(\mathrm{kcal} / \mathrm{mole})^{a}$ & -87 & -87 & -87 \\
\hline Maximum theore tical $\mathrm{O} / f$ & 0.334 & 0.334 & 0.334 \\
\hline \multicolumn{4}{|l|}{$\begin{array}{l}\text { Less combined oxygen } \\
\qquad y \text { moles } \mathrm{O} \text { as } \mathrm{CeO}_{1.5+y} \text { at: }\end{array}$} \\
\hline$y=0.5 ; 0.5 \times \frac{2.6 \mathrm{Ce}}{15 \text { fissions }}$ & 0.087 & & \\
\hline$y=0.45$ & & 0.078 & \\
\hline$y=0.2$ & & & 0.035 \\
\hline $\begin{array}{c}x \text { moles } \mathrm{O} \text { as } \mathrm{UO}_{2+x} \text { at: } \\
x=0.24 ; 0.24 \times 0.52\end{array}$ & 0.125 & & \\
\hline $\begin{array}{l}x=0.19 \\
x=0.14\end{array}$ & & 0.099 & 0.073 \\
\hline Calculated $\mathrm{O} / f$ released & 0.122 & 0.157 & 0.246 \\
\hline Actual $\mathrm{O} / \mathrm{f}^{b}$ & 0.084 & 0.20 & 0.35 \\
\hline
\end{tabular}

${ }^{a}$ See Fig. 7.5.

${ }^{b}$ See Eq. (7.1). 
It is also important to note that the in-reactor oxygen release in the HFIR must be considerably different from that measured out-of-reactor This results primarily from the presence of ${ }^{233} \mathrm{PaO}_{2+z}$ Table 75 gives the results of these calculations, which are analogous to those used for Tables 73 and 74 and were performed so that $\mathrm{O} / f, P_{\mathrm{CO}}$, and $R T \ln P_{\mathrm{O}_{2}}$ were mutually consistent Comparison of the calculated $\mathrm{O} / f$ values in Tables 73 and 74 indicates that significantly less oxygen is released in the HFIR at $\leqslant 1800^{\circ} \mathrm{K}$ Thus, prediction of in-reactor oxygen release for fission in $\mathrm{ThO}_{2}$ particles must be based on a reasonably precise knowledge of the time-dependent protactınium and uranium concentrations in a particular reactor environment

The oxygen release per fission for $\mathrm{ThO}_{2}$ in an HTGR can also be estimated The ${ }^{233} \mathrm{~Pa}$ and total uranium contents were calculated ${ }^{8}$ for typical HTGR conditions and are also shown in Fig 74 Here it can be seen that the in-HTGR uranium concentration is $\sim 05$ of the out-of-HFIR uranium concentration, whereas the ${ }^{233} \mathrm{~Pa}$ concentiation is insignificant for the mass-balance calculations Thus, since significantly less uranium is avalable in the HTGR $\mathrm{ThO}_{2}$ particles to form $\mathrm{UO}_{2+x}$, the $\mathrm{O} / f$ is increased to values higher than those calculated from Eq (7 1) Calculations similar to those in Tables 73 and 75 for HTGR burnup conditions at 5\% FIMA lead to the oxygen potential and $P_{\mathrm{CO}}$ values shown in Fig 78

Table 7.5. Estımated in-reactor oxygen released per fission at 5\% FIMA during HFIR irradiation

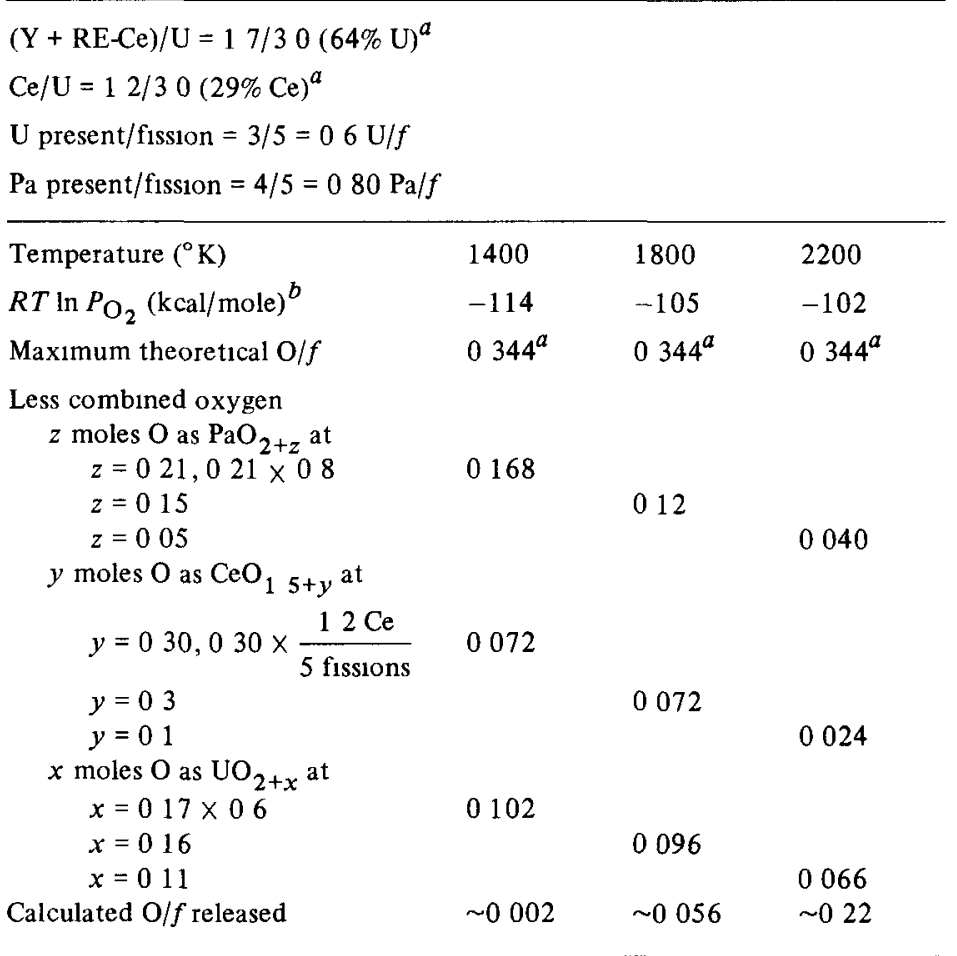

${ }^{a}$ The in reactor cerium contents now include the $47 \%$ yield of ${ }^{144} \mathrm{Ce}$ instead of the RE-daughter ${ }^{144} \mathrm{Nd}$, the mass-balance calculations reflect this change

${ }^{b}$ See Fig 75 


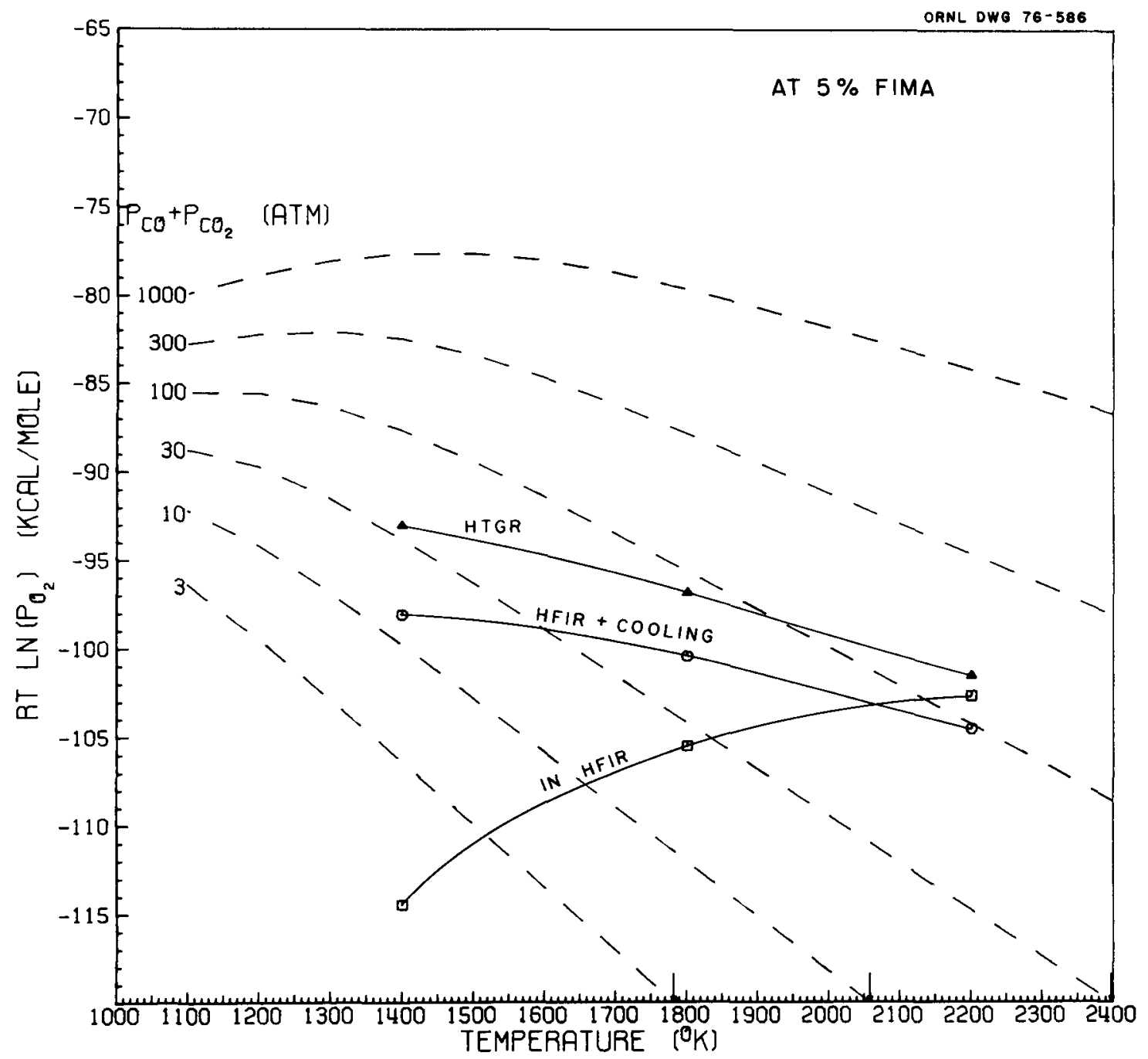

Fig. 7.8. Calculated oxygen potential and $P_{\mathrm{CO}}$ values in $\mathrm{ThO}_{2}$ particles at $5 \%$ FIMA for three different conditions: during irradiation in the HT position, after HT exposure and 1.5 to 2 years of cooling, and during irradiation in the HTGR. The assumed vord volume is 05 of the buffer volume

\section{References}

1. T. B. Lindemer and R. L. Pearson, "Apparatus for Measuring Gases from Irradiated Fuel Particles," J. Nucl. Mater. 55, 359-61 (1975).

2. G. W. Horsley, AERE, Harwell, private communication, March 1975.

3. D. J. Clough, G. W. Horsley, J. W. McMillan, B. E. Sheldon, B. L. Taylor, G. J. Weldrick, and J. Williams, "The Determination of Gases in Coated Particle and Ceramic Fuels," Post-Irradiation Examination Techniques, Proc. Conf. U. of Reading, 1972, British Nuclear Energy Society-Institute of Civil Engineers, London, 1972.

4. H. Bildstein and H. Strigl, "Determination of Free Volumes and Gas Content of Coated Fuel Particles for Gas-Cooled Reactors," Post-Irradiation Examination Techniques, Proc. Conf. U. of Reading, 1972, British Nuclear Energy Society-Institute of Civil Engineers, London, 1972. 
5. H. T. Kerr, ORNL, private communication, January 1976.

6. E. J. Allen, CACA-2: Revised Version of CACA-A Heavy Isotope and Fission-Product Concentration Calculational Codefor Experimental Irradiation Capsules, ORNL/TM-5266 (February 1976).

7. W. Knoch and S. Schieferdecker, Tagungsbericht der 3., Paper No. 10, Internationalen Protaktiniumkonferenz (Schloss Elmau bei Mittenwald, April 1969), H.-J. Born Institut für Radiochemie der Technischen, Universitat München (1971).

8. L. E. J. Roberts and A. J. Walker, "Tho Oxides of Protactinium," pp. 51-59 in Physico-Chimie der Protactinium, vol. 154, Colloques Internationaux du Centre National de la Recherche Scientifique, Paris, 1966.

9. T. B. Lindemer and H. J. de Nordwall, An Analysis of Chemical Failure of $\mathrm{UO}_{2}$ and Other Oxide Fuels in the High-Temperature Gas-Cooled Reactor, ORNL-4926, pp. 6-11 (January 1974).

10. K. Hagemark and M. Broli, "Equilibrium Oxygen Pressures Over the Nonstoichiometric Uranium Oxides $\mathrm{UO}_{2+x}$ and $\mathrm{U}_{3} \mathrm{O}_{8-z}$ at Higher Temperatures," J. Inorg. Nucl. Chem. 28, 2837-50 (1966).

11. S. Aronson and J. C. Clayton, "Thermodynamic Properties of Nonstoichiometric UraniaThoria Solid Solutions," J. Chem. Phys. 32, 749-54 (1960).

12. C. Keller, "On the Solid-State Chemistry of Protactinium Oxides," pp. 73-79 in PhysicoChimie du Protactinium, vol. 154, Colloques Internationaux du Centre National de la Rechershe Scientifique, Paris 1966.

13. T. L. Markin and E. C. Crouch, "Thermodynamic Data for U-Ce-Oxides," J. Inorg. Nucl. Chem. 32, 77-82 (1970).

14. J. F. Wadier, Phase Diagram and Thermodynamic Properties of the Uranium-NeodymiumOxygen System, CER-R-4507, p. 59 (November 1973).

15. J. M. Leitnaker, "Applications of Thermodynamics for Predicting and Understanding the Performance of Fast Breeder Reactor Oxide Fuels," J. Nucl. Mater. 51, 95-105 (1974).

16. E. Stadlbauer, U. Wichmann, U. Lott, and C. Keller, "Thermodynamics and Phase Relationships of the Ternary Lanthanum-Uranium-Oxygen System," J. Solid State Chem. 10, 341-50 (1974).

17. K. Hagemark and M. Broli, "Equilibrium Oxygen Pressures Over Solid Solutions of UraniaYttria and Urania-Lanthana at 1100 to $1400^{\circ}$ C, J. Am. Ceram. Soc. 50, 563 (1967).

18. C. A. Friskney and K. A. Simpson, "The Behavior of Fission-Product Barium and Strontium in Irradiated $\mathrm{UO}_{2}, "$ J. Nucl. Mater. 57, 121-22 (1975).

19. M. Koizumi, M. Satoh, and K. Noro, "Phase Study on Solid Fission Products Ba, Sr, and Zr in Oxide Fuel," J. Nucl. Mater. 51, 90-94 (1974).

20. L. Carlsson, "Non-Elastic Mechanical Behavior in $\mathrm{SrOZrO}_{3}$ by Reorientation," J. Mater. Sci. 5, 325-39 (1970).

21. C. E. Johnson, I. Johnson, P. E. Blackburn, and C. E. Crouthamel, "Effects of Oxygen Concentration on Properties of Fast Reactor Mixed-Oxide Fuel," React. Technol. 15, 303-38 (1973).

22. G. J. McCarthy and C. E. Gooden, "Compound Formation in the System Sr-Mo-O," J. Inorg. Nucl. Chem. 35, 2669-72 (1973).

23. V. B. Parker, D. D. Wagman, and W. H. Evans, Selected Values of Chemical Thermodynamic Properties, Tables for the Alkaline-Earth Elements, NBS Tech. Note 270-6, U.S. Government Printing Office, Washington, D.C., 1971.

24. J. E. Battles, W. A. Shinn, and P. E. Blackburn, "Thermodynamic Investigation of Trisodium Uranium(V) Oxide $\left(\mathrm{Na}_{2} \mathrm{UO}_{4}\right)$ IV, Mass Spectrometric Study of the $\mathrm{Na}+\mathrm{U}+\mathrm{O}$ System," J. Chem. Thermodyn. 4, 425-39 (1972). 
25. P. E. Blackburn, "Reaction of Sodium with Uranium-Plutonium Oxide and Uranium Oxide Fuels," pp. 393-410 in Behavior and Chemical State of Irradiated Ceramic Fuels, Proc. Panel, Vienna, August 1972, IAEA, Vienna, 1974.

26. P. A. G. O'Hare and H. R. Hoekstra, "Thermochemistry of Uranium Compounds IV. Standard Enthalpy of Formation of Sodium Uranium(V) Trioxide $\left(\mathrm{NaUO}_{3}\right)$, J. Chem. Thermodyn.6, 965-72 (1974).

27. P. A. G. O'Hare and H. R. Hoekstra, "Thermochemistry of U ranium Compounds II. Standard Enthalpy of Formation of -Sodium Uranate (-Na2 $\left.\mathrm{UO}_{4}\right)$," J. Chem. Thermodyn. 5, 769-75 (1973).

28. P. A. G. O'Hare and H. R. Hoekstra, "Thermochemistry of Uranium Compounds III. Standard Enthalpy of Formation of Cesium Uranate $\left(\mathrm{Cs}_{2} \mathrm{UO}_{4}\right)$," J. Chem. Thermodyn. 5, 251-58 (1974).

29. R. C. Weast, Handbook of Chemistry and Physics, 53rd ed., pp. D-64, D-69, D-70, The Chemical Rubber Co., Cleveland, Ohio, 1972. 


\section{FAILURE DETERMINATION}

This experiment was designed to confirm particle failure predictions and thereby establish minimal engineering coating design criteria rather than to demonstrate the ability of coated particles to successfully withstand reactor environments as in previous HFIR target capsules. To meet this objective it was necessary to determine, with certainty, whether a particular coating design survived or failed during irradiation. A further requirement is then to be able to establish failure determination procedures that are not ambiguous. At the time this experiment was planned, it was thought that the survivability of the Biso-coated $\mathrm{ThO}_{2}$ particles could be determined by postirradiation visual inspection alone. However, the results of gas pressure measurements described in Sect. 7.2 revealed the absence of fission gas in several coated particles reported intact by postirradiation visual examination; therefore, a more thorough study of coating failures was initiated. These studies compared the results of visual inspection, gas pressure measurements, hot chlorine leaching, and electron microscope examinations.

\subsection{Visual Inspection}

The results of the postirradiation visual inspection were reported in Sect 4.1 and listed in Table 4.1. These results indicated that three ORNL coating designs, OR-1838, OR-1840, and OR-1849, performed with few or no visible failures in capsules HT-12 through HT-15 with the exception of OR-1840 in HT-15. On this basis and on design considerations, coated particles from batches OR-1840 and OR-1849 were selected for extensive gas pressure and fission product release studies. Because of the disagreement between gas pressure measurements and visual inspections mentioned above, 6 to 16 coated particles from each of 13 irradiation holders containing coated particles from batches OR-1840 and OR-1849 were subjected to additional testing. These samples represented coated particles from each of the two batches irradiated at two temperatures and to four burnups, with three exceptions. There were insufficient coated particles available from two holders, and in one sample, OR-1840, 93\% of the coatings had visibly failed. Prior to hot chlorine leaching, each coated particle was carefully reinspected under a stereomicroscope. This visual inspection agreed with the visual results obtained in the hot cells previously.

\subsection{Hot Gaseous Chlorine Leaching ${ }^{1}$ and Associated Studies}

The samples of 6 to 16 coated particles were packaged in separate holes in porous graphite blocks to retain their individual identity and were leached with hot gaseous chlorine at $1000 \pm 100^{\circ} \mathrm{C}$. Prechlorination of the empty sample holders had removed impurities from the graphite. Leaching was carried to a minimum of $17 \mathrm{hr}$ if no thorium was collected. If thorium was collected initially, the leaching was continued in $20-\mathrm{hr}$ steps until the accumulative thorium ceased to increase. The maximum total time required was $60 \mathrm{hr}$. This procedure ensured collection of the total thorium content of the defective particles. In all but two samples involving coating failures, the maximum amount of thorium was collected during the first leaching step. In the two where thorium increased during the second step, the initial porosity was probably small and increased as a result of reaction during leaching. Such a reaction occurs between the thorium oxide and carbon where chlorine penetrates through to the fuel kernel. The condensed fission products and metal chlorides were leached with a dilute acid solution from the combustion system after each gas leach period. Total thorium in the leach solution was determined by the arsenazo III method, and the fission products were determined by gamma-ray spectrometry. The coated particles were passed over an ion chamber as they were unloaded after leaching to determine failures 
initially. In addition, most of the particles have been reanalyzed by gamma spectrometry to determine quantitatively the loss of fission products during leaching from each particle.

A comparison of the number of coating failures as determined by visual inspection, gas pressure measurements, and hot chlorine leaching is given in Table 8.1. The irradiation conditions are given also. The burnups given were determined from fission product inventories described in Sect. 6. Irradiation temperatures given were averaged over the irradiation period and, in the short irradiation capsule (HT-12), are about $100^{\circ} \mathrm{C}$ less than the maximum temperature. For the longer irradiation capsules the difference is not as great (see Appendix A). These results show that coating failures up to $100 \%$ (HT-15, holder 8), as indicated by gas pressure measurements and hot chlorine leach, were not discernable by visual examination. The results also show a fair agreement between the fraction of failures determined by particle activity measurements after leaching with that indicated by thorium collection during leaching. The thorium results, however, are low by 15 to $25 \%$.

A comparison of the fraction of failures for each batch in the same irradiation capsule indicates that the highest number of failures occurred at the lower conditions of temperature, burnup, and fast fluence. This is illustrated in capsules HT-14 and -15 by comparing the failures in holder 8 with those in holder 21 , and those in holder 13 with those in holder 26. A slight exception exists at lower burnups, where 1 out of 16 leached particles failed in capsule HT-12, holder 26.

In Table 8.2 the fraction of fission products collected during leaching is compared with the fraction of coating failures and the fraction of thorium collected. The fraction of fission products collected is based on the totals as analyzed in the particles before leaching. The ${ }^{144} \mathrm{Ce}$ and ${ }^{137} \mathrm{Cs}$ results agree more closely with the true failure fraction than do the ${ }^{232}$ Th results, with the exception of one cesium analysis; however, the 232 Th results are more uniform.

The cesium and cerium losses during leaching from individual coated particles are presented in Tables 8.3 and 8.4 respectively. Post-leach analyses are still continuing, but these data represent most of the series, since analyses will not be performed on particles that were definitely shown to be defective.

The pre-leach analyses were performed on a different spectrometry system than were the post-leach analyses. Although standards were used for calibration, calibration errors still occurred. In most cases the pre-leach inventories averaged less for intact coated particles than did the post-leach inventories, and the assumption was made that our calibration procedure has improved with time. Therefore, earlier values were corrected using a constant factor to agree with the later results, with the exception of samples HT-12-21 and HT-12-26. The pre-leach analyses of these sets of particles were taken at a later date and were higher than the post-leach results. The average negative loss before correction is indicated in the tables as bias.

Three defective coated particles were analyzed after leaching. The cesium and cerium losses ranged from 98 to $100 \%$ in these particles. Of the intact coated particles, only particle 4 from HT-13-26 showed a loss of cesium and cerium outside the scatter of the data. This exception could be a possible indication of the beginning of a failure caused by chlorine penetration of an intact coating. It could also indicate that the coating was beginning to fail during irradiation, or it could be the result of an analytical error.

All of the coated particles that failed were inspected under the stereomicroscope after leaching to determine the type of failure, with the exception of those from holder HT-14-13 and the one particle failure in HT-12-26. Only three coatings were definitely cracked out of the 32 defective coated particles inspected. Three other coatings had holes in the surface after leaching. No other defects were visible. The holes were caused by a reaction involving the fuel, chlorine, and coatings. This would occur only if chlorine can penetrate the coating; this reaction can be suppressed by the addition of $\mathrm{CO}$ to the leach gas. 
Table 8.1. Fallures in Biso-coated $\mathrm{ThO}_{2}$ particles from $\mathrm{HT}-12$ through HT-15 capsules as determıned by different methods

\begin{tabular}{|c|c|c|c|c|}
\hline & \multicolumn{4}{|c|}{ Capsule } \\
\hline & HT-12 & HT-13 & HT-14 & HT -15 \\
\hline \multicolumn{5}{|c|}{ Holder 8, batch OR-1840, desıgn ${ }^{a} 402-25-50$} \\
\hline Average temperature $\left({ }^{\circ} \mathrm{C}\right)$ & 1090 & 1190 & 1250 & 1260 \\
\hline Burnup (\% FIMA) & 1 & 3 & 7 & 10 \\
\hline Fast fluence $\left(n v t \times 10^{21}, E>018 \mathrm{MeV}\right)$ & 3 & 6 & 9 & 11 \\
\hline \multicolumn{5}{|l|}{ Fallures } \\
\hline Visual inspection $(\%)^{b}$ & 0 & 0 & 0 & 0 \\
\hline Gas pressure $^{c}$ (fraction ${ }^{d}$ ) & $\mathrm{ND}^{e}$ & $0 / 6$ & $3 / 3$ & ND \\
\hline \multicolumn{5}{|l|}{ Hot chlorine leach } \\
\hline Fallures by particle activity (\%) & 0 & 6 & 94 & 100 \\
\hline $\mathrm{ThO}_{2}$ collected (\% of total) & 0 & 5 & 80 & 76 \\
\hline Number of particles leached & 16 & 16 & 16 & 6 \\
\hline \multicolumn{5}{|c|}{ Holder 21 , batch OR-1840, design ${ }^{a} 402-25-50$} \\
\hline Average temperature $\left({ }^{\circ} \mathrm{C}\right)$ & 1370 & 1460 & 1500 & 1500 \\
\hline Burnup (\% FIMA) & 1 & 6 & 13 & 16 \\
\hline Fast fluence $\left(n v t \times 10^{21}, E>018 \mathrm{MeV}\right)$ & 4 & 8 & 14 & 16 \\
\hline \multicolumn{5}{|l|}{ Fallures } \\
\hline Visual inspection $(\%)^{b}$ & 0 & 0 & 0 & 93 \\
\hline Gas pressure $^{c}$ (fraction ${ }^{d}$ ) & ND & $0 / 10$ & $3 / 8$ & ND \\
\hline \multicolumn{5}{|l|}{ Hot chlorine leach } \\
\hline Falures by partıcle activity (\%) & 0 & 0 & 19 & ND \\
\hline $\mathrm{ThO}_{2}$ collected (\% of total) & 0 & 0 & 14 & ND \\
\hline Number of partıcles leached & 16 & 16 & 16 & 0 \\
\hline \multicolumn{5}{|c|}{ Holder 13 , batch OR-1849, design ${ }^{a} 508-79-75$} \\
\hline Average temperature $\left({ }^{\circ} \mathrm{C}\right)$ & 1180 & 1270 & 1320 & 1330 \\
\hline Burnup (\% FIMA) & 1 & 5 & 9 & 11 \\
\hline Fast fluence $\left(n v t \times 10^{21}, E>018 \mathrm{MeV}\right)$ & 3 & 7 & 11 & 13 \\
\hline \multicolumn{5}{|l|}{ Faulures } \\
\hline Visual inspection $(\%)^{b}$ & 0 & 0 & 0 & 0 \\
\hline Gas pressure $^{c}\left(\right.$ fraction $^{d}$ ) & ND & ND & $2-3 / 6$ & $2 / 3$ \\
\hline \multicolumn{5}{|l|}{ Hot chlorine leach } \\
\hline Fallures by particle actıvity (\%) & 0 & 0 & 75 & 88 \\
\hline $\mathrm{ThO}_{2}$ collected (\% of total) & 03 & 0 & 58 & 70 \\
\hline Number of particles leached & 16 & 12 & 8 & 8 \\
\hline \multicolumn{5}{|c|}{ Holder 26 , batch OR-1849, design ${ }^{a}$ 508-79-75 } \\
\hline Average temperature $\left({ }^{\circ} \mathrm{C}\right)$ & 1450 & 1520 & 1550 & 1550 \\
\hline Burnup (\% FIMA) & 1 & 6 & 14 & 16 \\
\hline Fast fluence $\left(n v t \times 10^{21}, 018 \mathrm{MeV}\right)$ & 4 & 9 & 14 & 16 \\
\hline \multicolumn{5}{|l|}{ Falures } \\
\hline Visual inspection $(\%)^{b}$ & 0 & 0 & 0 & 3 \\
\hline Gas pressure $^{c}$ (fraction $^{d}$ ) & $0 / 3$ & $0 / 6$ & $0 / 5$ & $0 / 5$ \\
\hline \multicolumn{5}{|l|}{ Hot chlorine leach } \\
\hline Falures by partıcle activity (\%) & 6 & 0 & ND & 0 \\
\hline $\mathrm{ThO}_{2}$ collected (\% of total) & 5 & 0 & ND & 0 \\
\hline Number of particles leached & 16 & 16 & 0 & 8 \\
\hline
\end{tabular}

${ }^{a}$ Design gives kernel diameter, buffer thickness, and outer coatıng thickness, all dimensions are in microns

${ }^{b}$ Sample size of 50 to 75 coated particles

${ }^{c}$ Fallures determined by absence of fission gas durıng pressure measurements

${ }^{d}$ The denominators of fractions used in the table are the numbers of particles inspected

${ }^{e}$ ND - not determined 
Table 8.2. Fission products and thorium collected during chlorine leaching at $1000^{\circ} \mathrm{C}$ [fraction of total (\%)]

\begin{tabular}{lcccccccc}
\hline Sample & $\begin{array}{c}\text { Number of } \\
\text { particles }\end{array}$ & ${ }^{106} \mathrm{Ru}$ & ${ }^{125} \mathrm{Sb}$ & ${ }^{137} \mathrm{Cs}$ & ${ }^{144} \mathrm{Ce}$ & ${ }^{232} \mathrm{Th}$ & $\begin{array}{c}\text { Number of } \\
\text { particles } \\
\text { failed }\end{array}$ & $\begin{array}{c}\text { Failures } \\
(\%)\end{array}$ \\
\hline HT-12-8 & 16 & $\leqslant 0.02$ & $\leqslant 0.01$ & $\leqslant 0.004$ & $\leqslant 0.002$ & $<0.02$ & $0 / 16$ & 0.0 \\
HT-12-13 & 16 & $\mathrm{ND}^{a}$ & 0.18 & 0.040 & 0.028 & 0.33 & $0 / 16$ & 0.0 \\
HT-12-21 & 16 & 0.24 & 0.097 & 0.015 & 0.32 & $<0.02$ & $0 / 16$ & 0.0 \\
HT-12-26 & 16 & 4.8 & $\mathrm{ND}$ & 5.2 & 4.8 & 4.8 & $1 / 16$ & 6.2 \\
HT-13-8 & 16 & 5.9 & $\mathrm{ND}$ & 5.2 & 5.5 & 4.9 & $1 / 16$ & 6.2 \\
HT-13-13 & 12 & ND & ND & 0.007 & 0.002 & $<0.014$ & $0 / 16$ & 0.0 \\
HT-13-21 & 16 & $\leqslant 0.011$ & $\leqslant 0.022$ & 0.037 & 0.005 & 0.021 & $0 / 16$ & 0.0 \\
HT-13-26 & 16 & 0.035 & 0.060 & 0.004 & 0.014 & $<0.01$ & $0 / 16$ & 0.0 \\
HT-14-8 & 16 & 110 & ND & 82 & 103 & 80 & $15 / 16$ & 93.8 \\
HT-14-13 & 8 & 57 & ND & 62 & 76 & 58 & $6 / 8$ & 75.0 \\
HT-14-21 & 16 & 16 & $\leqslant 14$ & 6.9 & 17 & 14 & $3 / 16$ & 18.8 \\
HT-14-26 & 0 & & & & & & & \\
HT-15-8 & 6 & 106 & 81 & 109 & 114 & 76 & $6 / 6$ & 100.0 \\
HT-15-13 & 8 & 28 & $\leqslant 40$ & 77 & 95 & 70 & $7 / 8$ & 87.5 \\
HT-15-21 & 0 & & & & & & & \\
HT-15-26 & 8 & 0.32 & 2.4 & 3.1 & 0.085 & $<0.047$ & $0 / 8$ & 0.0 \\
\hline
\end{tabular}

${ }^{a}$ Not determined.

Table 8.3. Cesium loss during chlorine leaching at $1000^{\circ} \mathrm{C}(\%)$

\begin{tabular}{crrrrrrrr}
\hline Particle & HT-12-8 & HT-12-13 & HT-12-21 & HT-12-26 & HT-13-8 & HT-13-13 & HT-13-26 & HT-14-21 \\
\hline 1 & ND $^{a}$ & +1 & 0 & 0 & +2 & -2 & 0 & +2 \\
2 & -4 & -3 & +1 & +2 & -1 & +3 & +2 & 0 \\
3 & -3 & 0 & +2 & +99 & -12 & 0 & 0 & +2 \\
4 & +1 & 0 & -1 & -3 & +3 & +1 & $+7^{b}$ & -2 \\
5 & +2 & +1 & +1 & +1 & +2 & +2 & +1 & ND \\
6 & -8 & -2 & +1 & +1 & +2 & -1 & +1 & -2 \\
7 & +3 & +1 & +3 & +4 & +1 & 0 & -1 & -1 \\
8 & -2 & +1 & +6 & +2 & -3 & -4 & +1 & +3 \\
9 & +1 & +2 & +1 & +2 & +3 & 0 & 0 & +99 \\
10 & +2 & +2 & +3 & -2 & -1 & 0 & -1 & +98 \\
11 & -1 & +3 & +3 & +1 & -2 & 2 & -2 & ND \\
12 & +4 & +2 & +2 & +2 & ND & 1 & +1 & -1 \\
13 & -1 & -7 & +2 & 0 & +2 & & +1 & -2 \\
14 & +1 & 0 & +3 & +1 & +2 & & 0 & +1 \\
15 & +3 & -1 & +2 & -6 & +1 & & 0 & -1 \\
16 & +2 & +1 & +1 & -3 & +1 & & -1 & +1 \\
Av. $\operatorname{loss}^{c}$ & 0 & 0 & 1 & 0 & 0 & 0 & -4 & -4 \\
Bias & 0 & -2 & 0 & 0 & -4 & -4 & -4 & +3 \\
\hline
\end{tabular}

${ }^{a}$ Not determined.

${ }^{b}$ This particle may have begun to fail. Data were not used in averages.

${ }^{c}$ Data from intact coated particles only.

${ }^{d}$ Original inventories averaged less than final inventories because of spectrometer calibration errors. Original inventories were corrected for these amounts. 
Table 8.4. Cerium loss during chlorine leaching at $1000^{\circ} \mathrm{C}(\%)$

\begin{tabular}{ccccccccc}
\hline Particle & HT-12-8 & HT-12-13 & HT-12-21 & HT-12-26 & HT-13-8 & HT-13-13 & HT-13-26 & HT-14-21 \\
\hline 1 & ND $^{a}$ & +3 & +1 & +3 & +4 & -4 & -2 & +2 \\
2 & -3 & -6 & +8 & +2 & -8 & +1 & -11 & -2 \\
3 & -1 & +1 & -2 & +98 & -10 & -1 & +13 & +5 \\
4 & -1 & +3 & -2 & +1 & -1 & +4 & $+21^{b}$ & -3 \\
5 & +5 & +5 & +5 & -4 & +3 & -2 & -2 & ND \\
6 & -3 & -6 & -2 & +1 & -1 & +4 & +6 & -4 \\
7 & +1 & +3 & +1 & +6 & +1 & 0 & -3 & +4 \\
8 & -4 & 0 & +5 & 0 & -5 & -5 & +8 & -2 \\
9 & +1 & +4 & +5 & -2 & +5 & +3 & -3 & +100 \\
10 & -6 & -1 & +7 & +6 & -9 & -5 & +7 & +99 \\
11 & -5 & +2 & +8 & +5 & +3 & +2 & -4 & -2 \\
12 & +3 & +3 & -1 & +6 & ND & +3 & -3 & -2 \\
13 & +3 & -3 & +5 & -1 & +4 & & -1 & +2 \\
14 & +4 & 0 & +2 & +2 & +4 & & -1 & 0 \\
15 & +6 & -11 & +4 & -5 & +9 & & -3 & -1 \\
16 & 0 & +5 & +5 & -1 & 0 & & -2 & +3 \\
Av. loss $c$ & 0 & 0 & +3 & +1 & 0 & 0 & 0 & -2 \\
Bias & -2 & -4 & 0 & 0 & -6 & -6 & -2 & -4 \\
\hline
\end{tabular}

\footnotetext{
${ }^{a}$ Not determined.

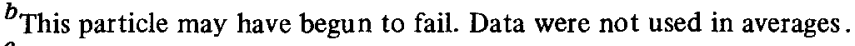

${ }^{c}$ Data from intact coated particles only.

${ }^{d}$ Original inventories averaged less than final inventories because of spectrometer calibration errors Original inventories were corrected for these amounts.
}

\subsection{Scanning Electron Microscope Studies}

Several defective coated particles were examined under the scanning electron microscope (SEM). Scanning electron micrographs of coatings from HT-15-21, batch OR-1840, of which $93 \%$ failed by visual inspection, are shown in Figs. 8.1 and 8.2. Apparently, fragments of fuel from adjacent failed particles had reacted with the coating of the particle shown in Fig. 8.1. Figure $8.1 \mathrm{~b}$ is an enlargement of some of the fragments embedded in the coating. The enlargement of another area of the same coating in Fig. 8.1c shows an apparent surface porosity and a fibrous structure. It is uncertain whether the particle shown in Fig. 8.2 has a coating or not. The cracks seen in the enlarged view in Fig. $8.2 \mathrm{c}$ might indicate melting during irradiation.

Micrographs of defective coated particles from holder HT-14-21 are shown in Figs. 8.3, 8.4, and 8.5. Figure 8.3 is a comparison of micrographs from an unleached coated particle, on the left, with a leached coated particle on the right. The surface porosity in the unleached coating is larger than in the leached coating. However, these micrographs may not be typical of other coated particles, even in the same holder. The hole in the leached coated parricle is shown in more detail in Fig. 8.4. The hole was caused by a reaction between the fuel, chlorine, and pyrocarbon. The pits adjacent to the hole may be the results of the same reaction if bits of fuel were ejected during chlorination. This coating was broken under pressure to obtain the cross-section views in Fig. 8.4b and 8.4d. Views of the cross section of the same coating at a location opposite the hole are shown in Fig. 8.5. Note that the porous, fibrous structure at the coating surface is only a few microns in depth. In the enlargement at 10,000X in Fig. 8.5d, concentric-spherical growth features are seen interspaced among a somewhat layered structure.

A comparison between leached coated particles, one of which survived and the other failed, is shown in Fig. 8.6. The apparent surface porosity seen in the coatings in Figs. 8.1, 8.3, 8.4, and 8.5 is absent in these coatings. No distinct difference is shown between the coating that survived and the one that failed. 

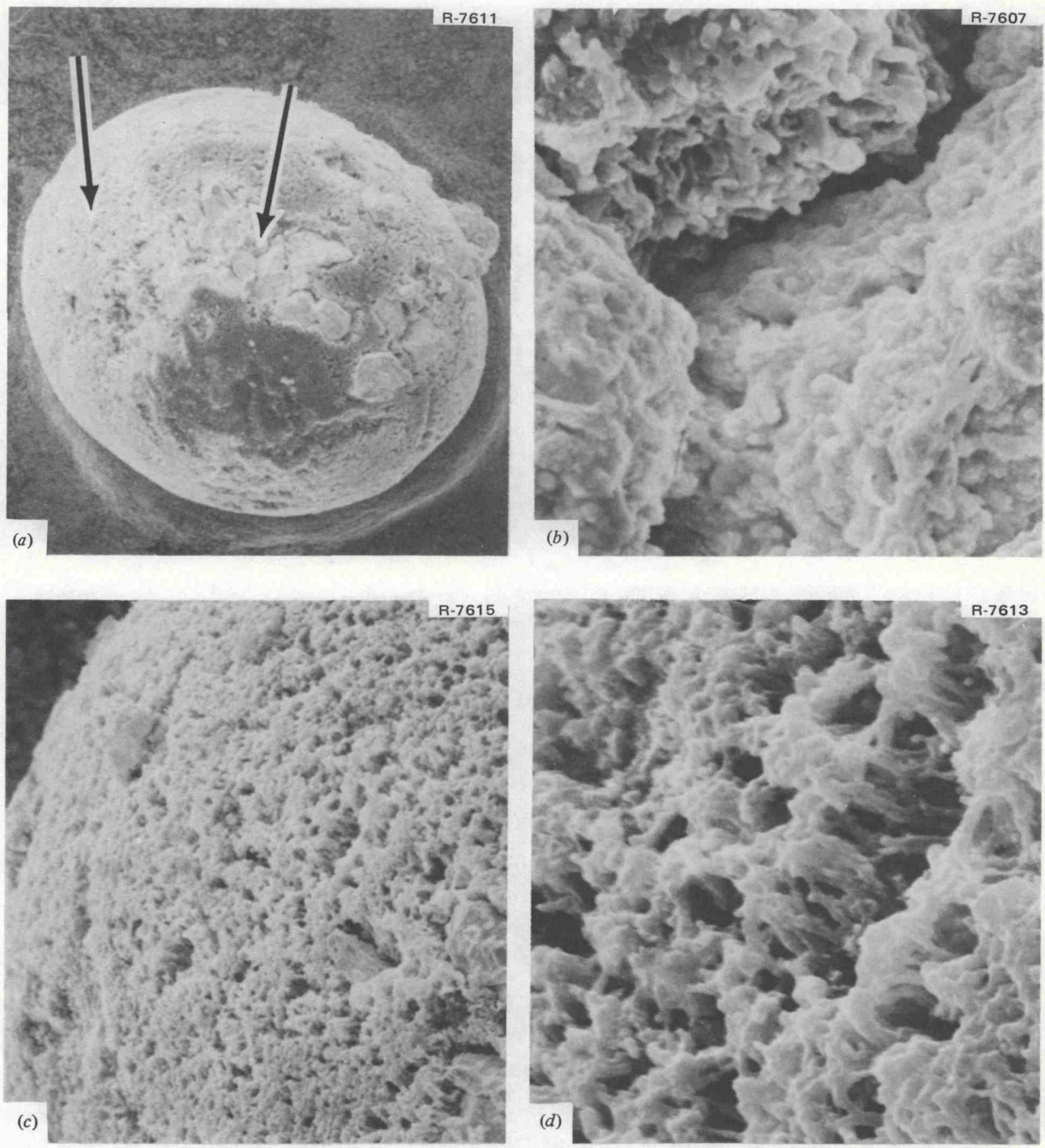

Fig. 8.1. Scanning electron micrographs of Biso-coated $\mathrm{ThO}_{2}$ particles from HT-15-21, batch OR-1840, irradiation temperature $1550^{\circ} \mathrm{C}$, burnup 20\% FIMA. 93\% gross failures. Coated particles were not leached. Shows interaction of coating with fragments of fuel, also the porosity and fibrous structure of the coating surface. (a) Overall view, 100X; (b) embedded fragments, $2000 \times ;(c)$ coating surface, $500 \times ;(d)$ coating surface, $2000 \times$. 

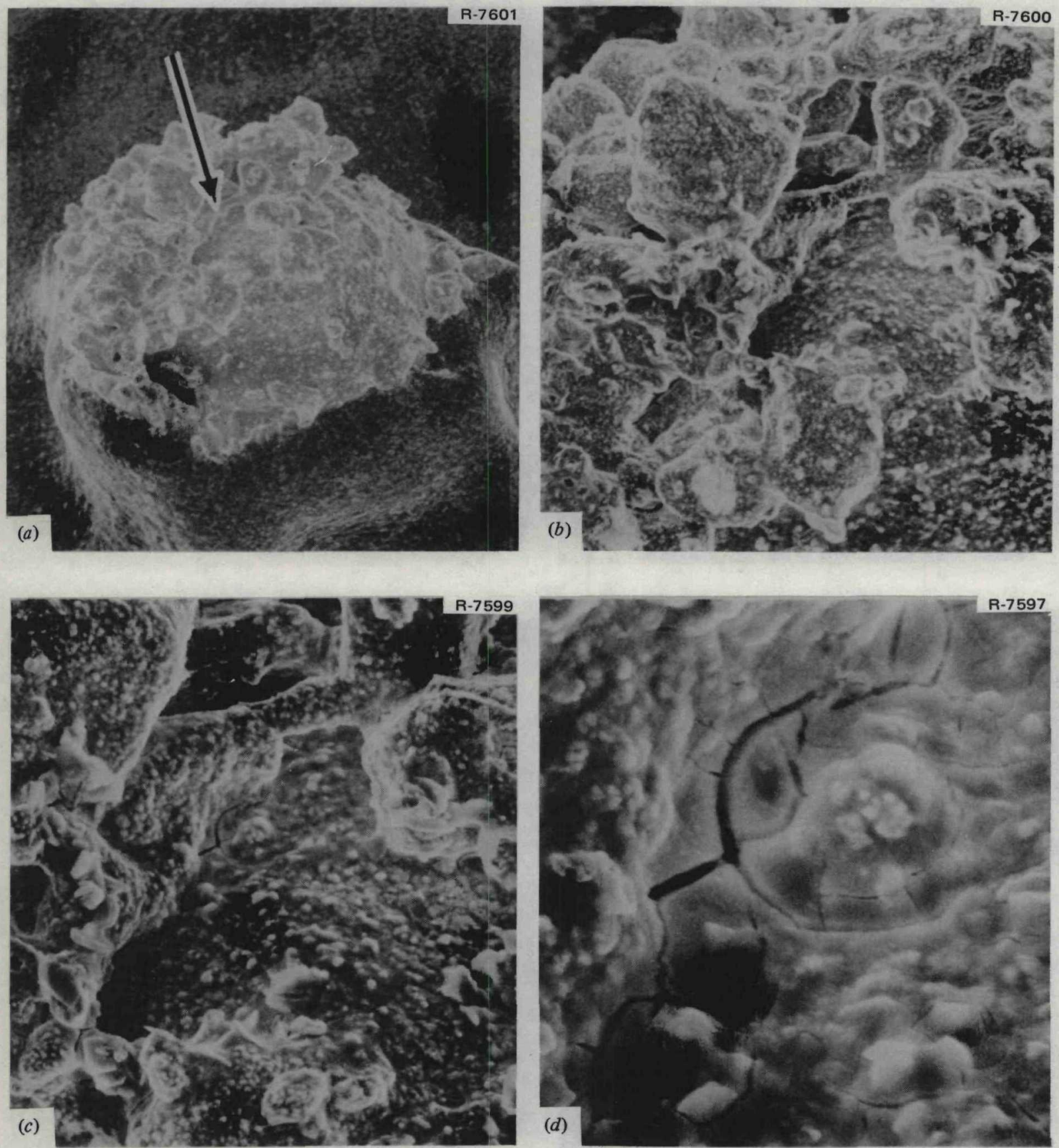

Fig. 8.2. Scanning electron micrographs of Biso-coated $\mathrm{ThO}_{2}$ particles from HT-15-21, batch OR-1840, irradiation temperature $1550^{\circ} \mathrm{C}$, burnup 20\% FIMA. 93\% gross failures. Coated particles were not leached: Shows grossly deformed particles with fuel or coating fragments attached to surface. One area appears to have been molten. (a) Overall view, 100X; (b) fragments to surface, $250 \mathrm{X}$; $(c)$ surface at $500 \mathrm{X}$; $(d)$ molten area, $2000 \mathrm{X}$. 

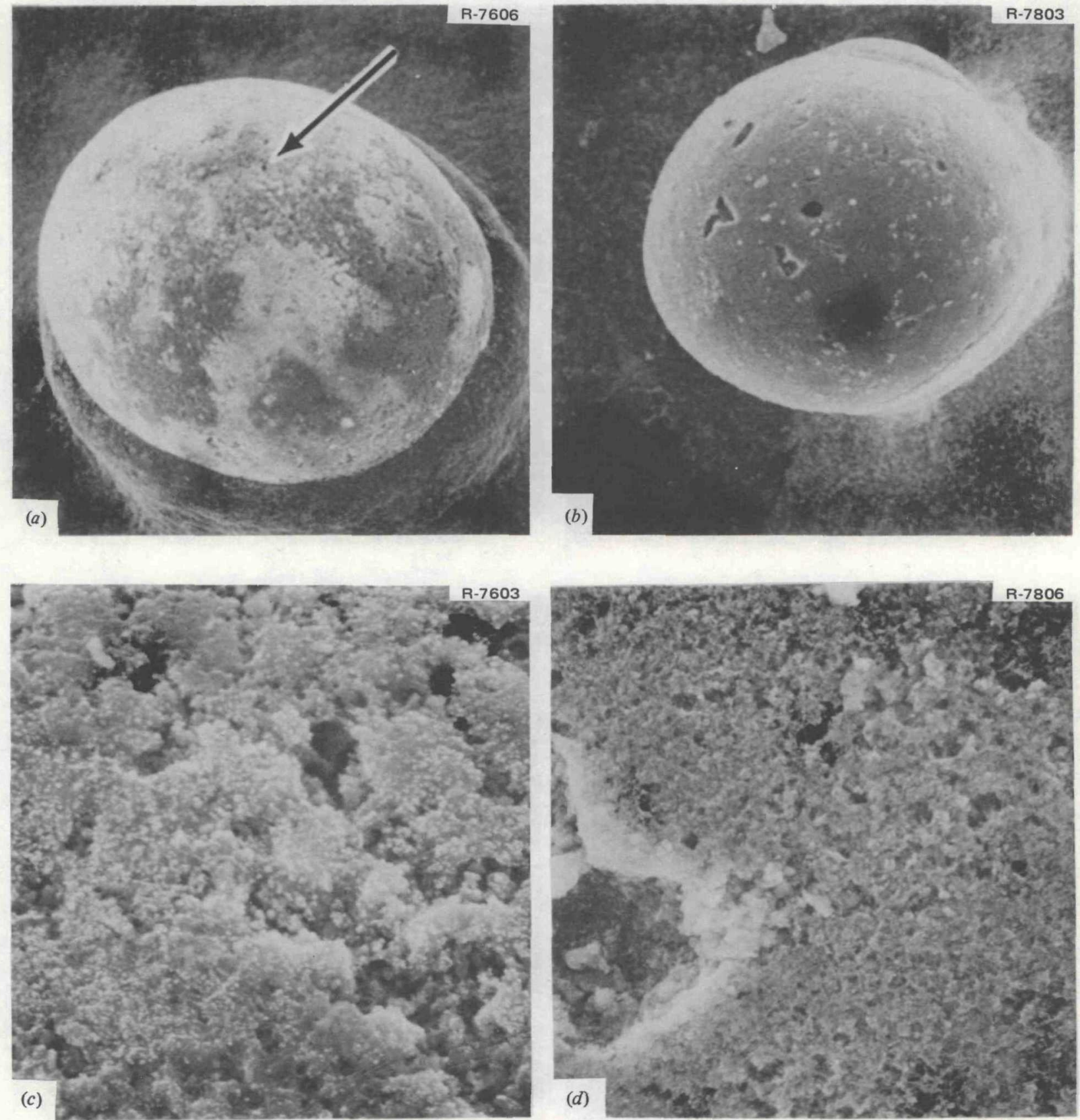

Fig. 8.3. Scanning electron micrographs of Biso-coated $\mathrm{ThO}_{2}$ particles from HT-14-21, batch OR-1840, irradiation temperature $1530^{\circ} \mathrm{C}$, burnup $16 \%$ FIMA. $19 \%$ failed. Compares surface of unleached coated particle with that of particle leached in chlorine at $1000^{\circ} \mathrm{C}$. (a) Overall view of unleached particle, 100X; (b) overall view of leached particle, 100X; $(c)$ surface of unleached particle, $1000 \times ;(d)$ surface of leached particle, $1000 \times$. 

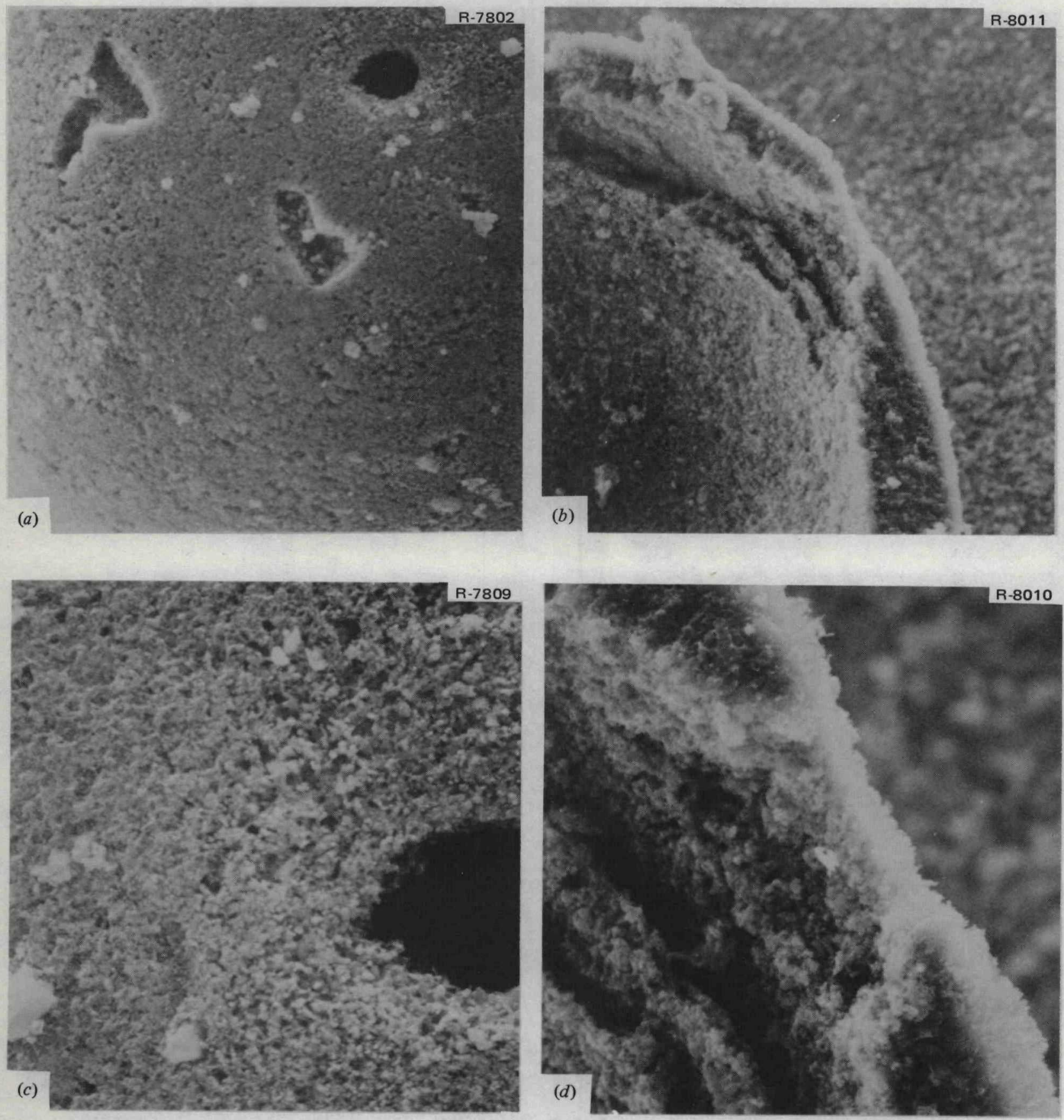

Fig. 8.4. Scanning electron micrographs of Biso-coated $\mathrm{ThO}_{2}$ particle from HT-14-21, batch OR-1840, irradiation temperature $1530^{\circ} \mathrm{C}$, burnup $16 \%$ FIMA. $19 \%$ failed. Shows hole in coating caused by fuel-chlorine-coating reaction during leaching. (a) View of hole and surface pitting, 300X; $(b)$ cross section of hole and coating, $300 \times$; $(c)$ enlarged view of hole, $1000 \times ;(d)$ enlarged cross-section view, $1000 x$. 

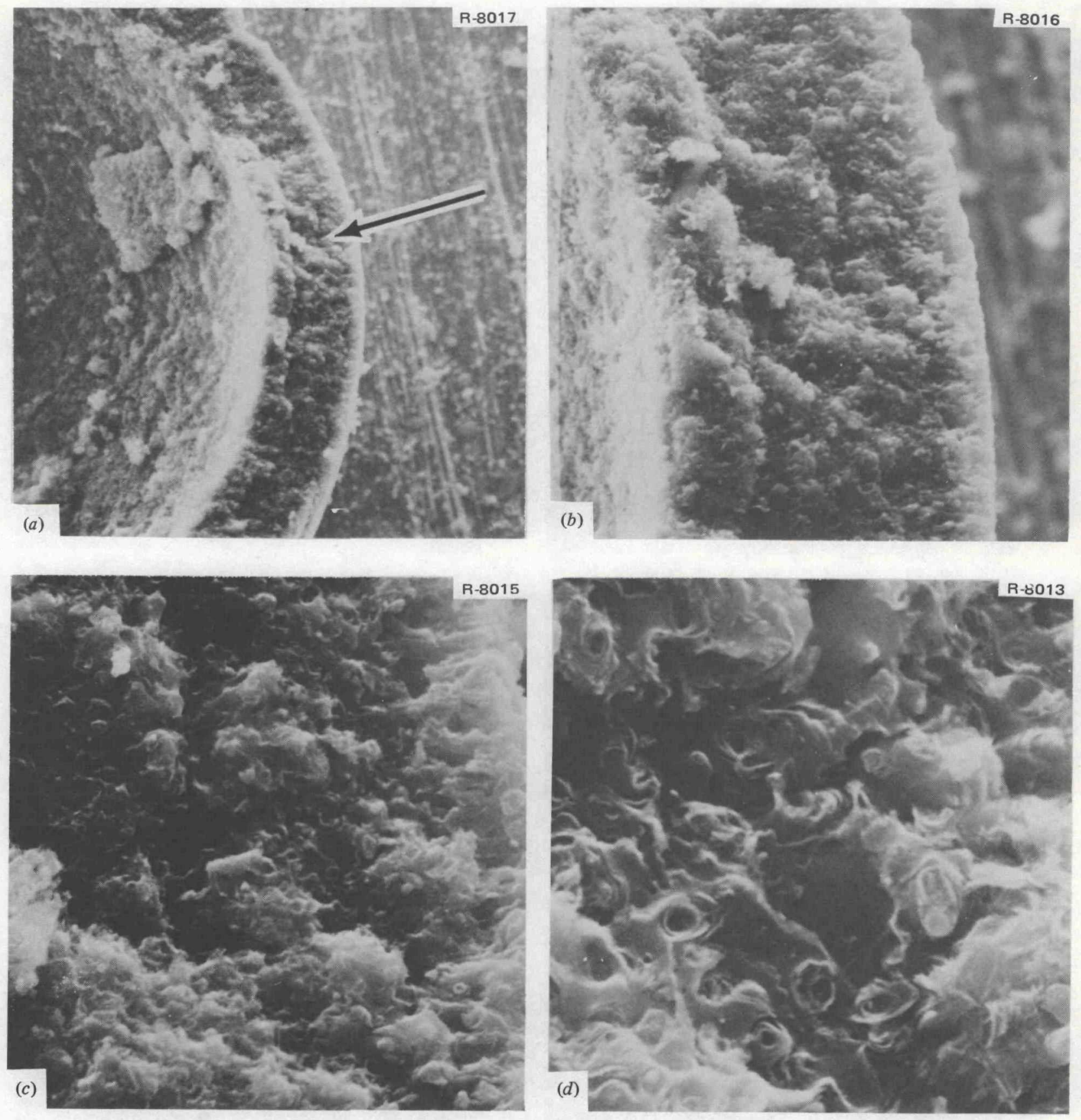

Fig. 8.5. Scanning electron micrographs of Biso-coated $\mathrm{ThO}_{2}$ particle from $\mathrm{HT}-14-21$, batch $\mathrm{OR}-1840$, irradiation temperature $1530^{\circ} \mathrm{C}$, burnup $16 \%$ FIMA. $19 \%$ failed. Shows particle was leached. Shows variation in structure across fractured edge of coating. (a) View of fractured edge opposite hole shown in Fig. 8.4, 300x; (b) edge view, 1000X; (c) edge view, 3000x; (d) edge view, 10,000x. 

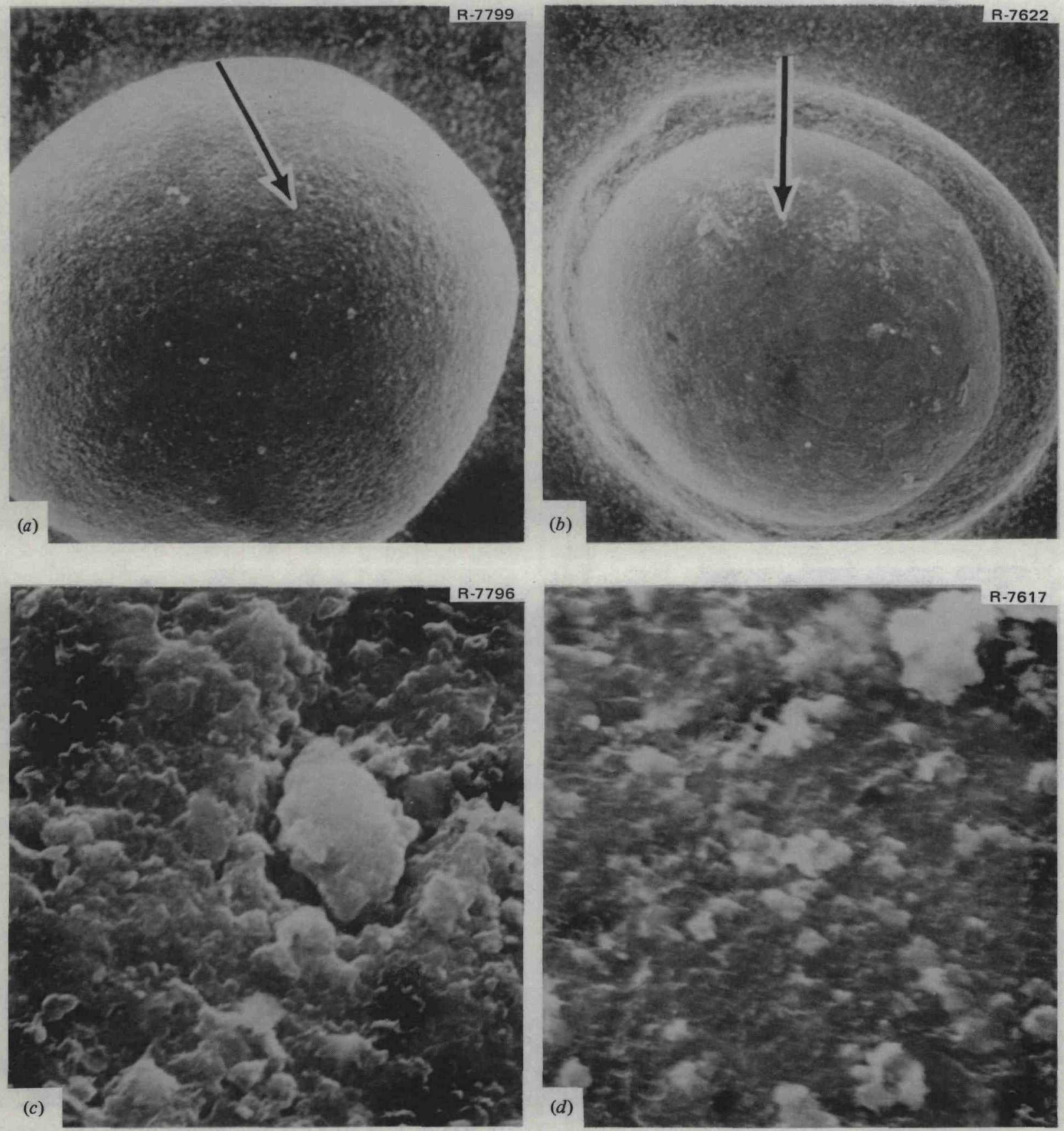

Fig. 8.6. Scanning electron micrographs of Biso-coated particles from HT-13-26, batch OR-1849, irradiation temperature $1490^{\circ} \mathrm{C}$, burnup $8 \%$ FIMA. None failed. Also from HT-15-8, batch OR-1840, irradiation temperature $1280^{\circ} \mathrm{C}$, burnup 15\% FIMA. $100 \%$ failed. Both particles were leached. Compares surfaces of permeable or defective coating with one which remained impermeable. (a) Overall view of particle with impermeable coating, 100X; $(b)$ overall view of defective coated particle, $100 \mathrm{X} ;(c)$ view of impermeable coating surface, $3000 \mathrm{X} ;(d)$ view of defective coating surface, $3000 x$. 
Micrographs of unirradiated, unleached, and leached coated particles were also taken to determine the effects of irradiation and leaching on the surface appearance. These are presented in Fig. 8.7; the unleached coatings are shown on the left, and the leached coatings are on the right. No difference can be found either in the surface or cross-section views of the coatings as a result of leaching. The granular appearance of the surfaces of unirradiated coatings is quite different from that of irradiated coated particles shown in Figs. 8.1, 8.3, 8.4, and 8.6. The fractured surface appearance is also different; the unirradiated surfaces show spherical details but lack the distinct concentric rings shown in Fig. 8.5. This difference could be an artifact caused by differences in viewing angles.

\subsection{Discussion of Results}

The lack of any evidence of coating failure in either optical or scanning electron microscopy suggests that the permeability observed in some of the coatings in these experiments is due either to microcracks or porosity. Since no failures were detected by $1000^{\circ} \mathrm{C}$ gaseous chlorine leaching of unirradiated control particles, the failures in the irradiated coated particles must have occurred during irradiation.

Kaae, ${ }^{2}$ using electron microscopy, has shown that internal cracks developed in unirradiated pyrocarbon deposited from propane at $1300^{\circ} \mathrm{C}$ during an anneal at $1900^{\circ} \mathrm{C}$ for $2 \mathrm{hr}$. The pyrocarbon had an as-coated density of $2.04 \mathrm{~g} / \mathrm{cm}^{3}$, a crystallite size $\left(L_{c}\right)$ of $33 \AA$, and a Bacon anisotropy factor (BAF) of 1.00. The cracks were of the same length as the largest pore size in the as coated material, $\mathrm{Kaae}^{3}$ also found that cracks developed in high-density propane-derived pyrocarbon irradiated to a fluence beyond $2 \times 10^{21} \mathrm{nvt}$ $(E>0.18 \mathrm{MeV})$. This pyrocarbon had an as-coated density of $2.04 \mathrm{~g} / \mathrm{cm}^{3}$, a crystallite size of $33 \AA$, and a BAF of 1.30. After irradiation to a fast fluence of $7.7 \times 10^{21} n v t$ at 1550 to $1600^{\circ} \mathrm{C}$, the cracks were numerous both around the growth features of the pyrocarbon and within the growth features. It was suggested that the development of the cracks was responsible for the decrease in density observed above intermediate fluences. Kaae found no cracks either after annealing or irradiation in low-density pyrocarbon, and after the initial densification, the density remained nearly constant to a fast-neutron fluence of $8 \mathrm{X}$ $10^{21} n v t$.

The width of the largest cracks shown in the electron micrographs by Kaae appears to be up to several hundred angstroms. Since the ionic radii of $\mathrm{Cl}, \mathrm{Cs}, \mathrm{Kr}, \mathrm{Xe}$, and $\mathrm{ThCl}_{4}$ are $1.8,2.7,1.9,2.1$, and $3.6 \AA$, respectively, a network of cracks and pores could serve to account for the permeability observed in these experiments in the lower-temperature samples. However, if microcracks became interconnected, one would expect the pyrocarbon strength to decrease, resulting eventually in explosive fragmentation due to the internal gas pressure in the coated particles. More coatings failed at the lower temperature $\left(\sim 1200^{\circ} \mathrm{C}\right)$ than at the higher temperature $\left(\sim 1500^{\circ} \mathrm{C}\right)$. The pyrocarbon densities in batches OR-1840 and OR-1849 were 2.01 and $1.99 \mathrm{~g} / \mathrm{cm}^{3}$ respectively. Perhaps at the higher temperature, the increased creep rate served to accommodate dimensional change and to diminish crack formation. Pyrocarbons reacting with fuel, fission products, or external contaminants could result in porosity occurring during irradiation.

Regardless of the type of failure, the primary significance of these results is that the coatings developed permeability during irradiation which could not be detected visually. It is also doubtful that metallography would show such failures. Fission gas release during irradiation or annealing would detect this type of failure but could not distinguish permeability from pressure vessel failure. Since nearly all previous irradiation experiments have used visual inspection, metallography, or fission gas release for the detection of failures, and since fission gas release has been attributed to pressure vessel failure, the extent of failure due to the development of permeability during irradiation has not been assessed. All efforts in past coating development have been directed toward the design of coatings to withinstand pressure vessel failure during 

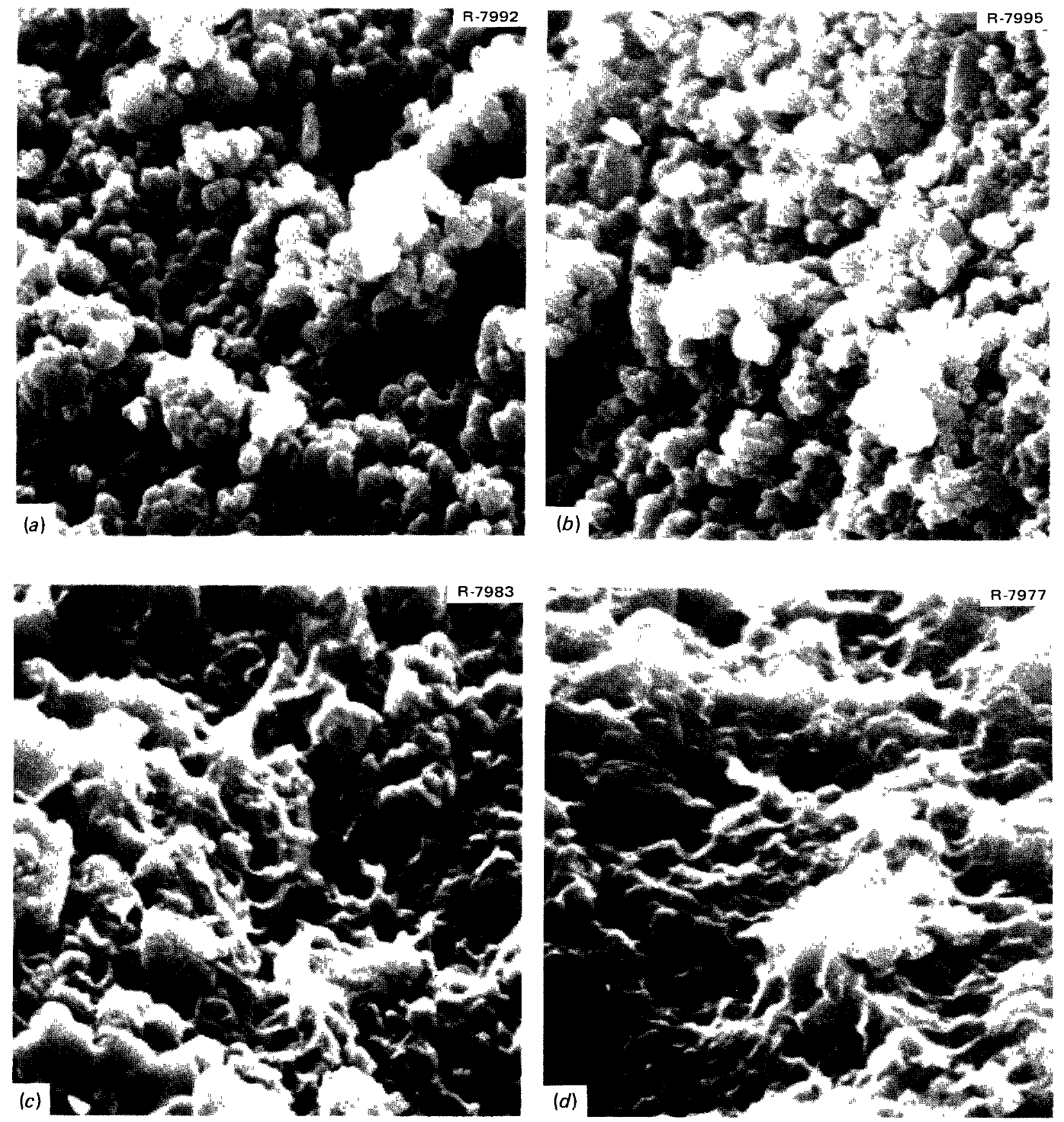

Fig. 8.7. Scanning electron micrographs of Biso-coated $\mathrm{ThO}_{2}$ particles from batch oR-1849, as coated. Compares appearances of surface and fractured edge of coatings of unleached particles with those of particles leached in chlorine at $1000^{\circ} \mathrm{C}$ for $17 \mathrm{hr}$. (a) Surface of unleached coating, 10,000X; (b) surface of leached coating, 10,000X; (c) fractured edge of unleached coating, 10,000x; (d) fractured edge of leached coating, 10,000X. 
irradiation. That research indicated that the coating density should be less than maximum for the coatings to survive the effects of fast-neutron damage. ${ }^{4}$ The coatings irradiated in this experiment were of a higher density (see Sect. 2.1). If the permeability observed here is the result of internal reactions or structural change, then the effect of coating characteristics on the development of irradiation-induced permeability must be considered.

The requirements for a coating that is resistant to the development of permeability may be similar to those necessary to prevent pressure vessel failure. However, these studies indicate that several coatings survived to approximately the design limits for HTGR fertile fuel. More research is necessary to verify whether irradiation-induced permeability is a problem and, if so, to define the optimum coating design to deter both pressure vessel failure and irradiation-induced permeability. Such studies should include the effects of a range of irradiation conditions.

These studies have also shown that visual inspection alone is insufficient to guarantee that coatings have not failed. The following discussion is directed toward methods of coating failure detection.

The visual inspection technique used in the post-irradiation examination (PIE) primarily detects cracked coatings. Microscopic defects are easily overlooked and submicroscopic defects would not be seen. At a magnification of 10,000 produced with the scanning electron, the width of cracks or pores necessary to pass gas atoms would be less than a micron, hardly visible, and difficult to interpret as well. Explosive failures often produce fragments small enough to mix with other debris, and these, too, cannot be quantitatively assessed by visual inspection.

The more rigorous investigations of gas measurements and hot gaseous chlorine leaching detect submicroscopic coating failures as well as gross failures. Gamma-counting the coated particles separately after-leaching, as was done in these experiments, can increase the accuracy in failure determination. However, gas pressure measurements and gaseous chloride leaching also have limitations.

Gas pressure measurements described in Sect. 7.2 were carried out to investigate kernel chemistry. There is some question as to whether the heating of coated particles above their irradiation temperature may have caused additional failures. These experiments are performed on single coated particles, are expensive and tedious, and therefore not useful for routine failure detection. An alternate method of gas detection, cracking single coated particles at room temperature for the collection of fission gas, has been used. ${ }^{5,6}$

The hot gaseous chlorine leaching procedure described previously is applicable only to Biso-coated particles. The possibility also exists that hot chlorine leaching can cause damage to the coatings, creating additional failures, especially at temperatures higher than $1000^{\circ} \mathrm{C}$. However, the results of these studies do not indicate that additional failures occurred. There were no failures found in the unirradiated control samples of 16 particles from each batch, and there were no failures observed in several irradiated samples. Also, no difference could be observed in the SEM micrographs of control and leached coatings up to magnifications of $10,000 X$.

A comparison of the failures detected by the two methods is given below:

Fraction of coated particles failed (\%)

\begin{tabular}{lcrccccccc}
\hline \multirow{2}{*}{ Method } & \multicolumn{10}{c}{ Sample HT- } \\
\cline { 2 - 9 } & $13-8$ & $14-8$ & $13-21$ & $14-21$ & $14-13$ & $15-13$ & $12-26$ & $13-36$ & $15-26$ \\
\hline \multirow{2}{*}{ Gas pressure } & 0 & 100 & 0 & 38 & 50 & 67 & 0 & 0 & 0 \\
Chlorine leach & 6 & 94 & 0 & 19 & 75 & 88 & 6 & 0 & 0 \\
\hline
\end{tabular}


Excess failures in the gas pressure method could be caused by the high temperatures used. It might be argued that excess failures in the chlorine leach values were caused by hot chlorine opening up porosity already developing in particles weakened by irradiation.

A method routinely used for quality control of unirradiated uncoated particles ${ }^{7}$ involves the determination of fission-gas release during the irradiation of samples of the coated particles for one-half hour at $1100^{\circ} \mathrm{C}$. The release to birthrate for ${ }^{85 m} \mathrm{Kr}$ (or other fission gases) is calculated and compared with that from similar coated-particle samples in which the coatings were precracked or laser drilled to predetermine a failure fraction. This method is applicable to loose coated particles or fuel rods. There is some uncertainty regarding comparison of gas release from cracked loose-coated particles with that from particles with cracked coatings constrained in a matrix. Also, variations in kernel characteristics will influence the results.

An alternative to the procedures studied here is a new system being designed and fabricated to provide statistically accurate determinations of HTGR fuel particle performance. ${ }^{8}$ The system, known as the irradiated microsphere gamma analyzer (IMGA), has as one of its primary functions the capability to determine the failure fraction of irradiated fuel particles, that is, the fraction of fuel particles that have lost a significant amount of their fission products through defective or broken coatings. This determination is made possible by the different volatilities of fission products that emit easily detectable gamma rays. An example would be ${ }^{95} \mathrm{Zr}$ and ${ }^{137} \mathrm{Cs}$. Because of the relatively low boiling point of cesium compared with zirconium $\left(678^{\circ} \mathrm{C}\right.$ and $4377^{\circ} \mathrm{C}$ respectively), cesium will diffuse or escape from a defective particle much more readily than zirconium in the high-temperature environment of an HTGR. Thus, a measurement of the ratio of ${ }^{137} \mathrm{Cs}$ activity to that of ${ }^{95} \mathrm{Zr}$ provides a direct measure of the particle's ability to retain fission products. An attractive feature of the ratio determination is its insensitivity to variation in the fuel particle design. It is anticipated that when IMGA is installed, it will be used to make all accurate failure fraction determinations.

If permeability is to be differentiated from pressure vessel failure, then visual inspection of loose or coated particles from deconsolidated fuel rods must be followed by a more positive method of failure detection of the apparently intact particles. Such determinations can be made by the hot gaseous chlorine leaching process or by the IMGA.

\section{References}

1. D. E. Lavalle, D. A. Costanzo, W. J. Lackey, and A. J. Caputo, The Determination of the Defective Particle Fraction in HTGR Fuels, ORNL/TM-5483, in publication.

2. J. L. Kaae, "The Effect of Annealing on the Microstructure and the Mechanical Properties of Poorly Crystalline Isotropic Pyrolytic Carbons," Carbon 10,691-99 (1972).

3. J. L. Kaae, "Irradiation-Induced Microstructural Changes in Isotropic Pyrolytic Carbons," J. Nucl. Mater. 57(1), 82-92 (July 1975).

4. D. P. Harmon and C. B. Scott, Development and Irradiation Performance of HTGR Fuel, GA-A13173, General Atomic Company (Oct. 31, 1975).

5. P. Koss and H. Bildstein, Testing and Evaluation of Reactor Fuel Particles, Dragon Project Report 408 (January 1965). 
6. M. T. Morgan, H. J. deNordwall, and R. L. Towns, Release of Fission Products from Pyrocarbon-Coated HTGR Fuel Particles During Postirradiation Anneals, ORNL/TM4539 (December 1974).

7. R. D. Burnette, W. E. Bell, and H. L. Baldwin, "Fission Product Retention Characteristics of HTGR Fuel," Nuclear Fuel Performance Conference, British Nuclear Energy Society, October 15-19, 1973, London, England, ed. C. T. John, International Scholarly Book Services, Inc., 1975.

8. K. H. Valentine and E. L. Long, "Fuel Particle Inspection with an Irradiated Microsphere Gamma Analyzer," ANS transactions, vol. 22, TANSAO 22 (1975), pp. 213-14. 


\section{FISSION PRODUCT RELEASE EXPERIMENTS}

This chapter consists of four sections: the release of fission products during irradiation, the release of fission products from bare $\mathrm{ThO}_{2}$ kernels during postirradiation annealing at $1400^{\circ} \mathrm{C}$, the concentration profiles for ${ }^{137} \mathrm{Cs}$ in Biso coatings of some of the fuel particles, and a summary of fission product release experiments.

\subsection{Fission Product Release During Irradiation}

The differences between the calculated and measured inventories of ${ }^{95} \mathrm{Zr},{ }^{106} \mathrm{Ru},{ }^{144} \mathrm{Ce},{ }^{125} \mathrm{Sb}$, and ${ }^{137} \mathrm{Cs}$ are listed, plotted, and discussed in this section. The fractional release or difference was calculated by the equation

$$
F R=\frac{C-A}{C} \times 100
$$

where

$$
\begin{aligned}
F R & =\text { release or difference in } \% \text { of the calculated value, } \\
C & =\text { calculated inventory } \\
A & =\text { analyzed inventory. }
\end{aligned}
$$

The calculated inventories were determined differently for the fission products not expected to be released $\left({ }^{95} \mathrm{Zr},{ }^{106} \mathrm{Ru}\right.$, and $\left.{ }^{144} \mathrm{Ce}\right)$ than for those released $\left({ }^{125} \mathrm{Sb}\right.$ and $\left.{ }^{137} \mathrm{Cs}\right)$. The methods of calculation are discussed below. The number of particles in each sample should be considered in the interpretation of the graphs. The raw data and the standard derivations are given in Appendix B, Table B.1.

No release of ${ }^{95} \mathrm{Zr},{ }^{106} \mathrm{Ru}$, and ${ }^{144} \mathrm{Ce}$ was expected during irradiation of the Biso-coated $\mathrm{ThO}_{2}$ particles. The differences between calculated and measured inventories of ${ }^{95} \mathrm{Zr},{ }^{106} \mathrm{Ru}$, and ${ }^{144} \mathrm{Ce}$ are listed in Table 9.1. The calculated values of these fission products were based on the average neutron flux at the horizontal midplane (HMP) determined from the analyzed inventories of ${ }^{95} \mathrm{Zr}$, ${ }^{106} \mathrm{Ru}$, and ${ }^{144} \mathrm{Ce}$ and multiplied by the attenuation factors for distance from the HMP. The neutron fluxes are given in Table 6.4 in Sect. 6, and the calculations for the inventories of the fission products are described in the same section. The values in Table 9.1 are plotted vs burnup in Figs. 9.1, 9.2, and 9.3. The burnups are those determined from the fission product inventories. The differences between calculated and measured inventories show no relation to temperature, and those for ${ }^{95} \mathrm{Zr}$ and ${ }^{106} \mathrm{Ru}$ show a decrease with burnup. This trend with burnup and the variation in the results for different fission products may reflect biased inaccuracies in analyses or input data such as effective yields, cross sections, or attenuation factors for distances used in the calculations. Also, no significant effects of coating failure beyond the scatter of the data are noted in these results.

Release of ${ }^{137} \mathrm{Cs}$ was expected from the Biso-coated $\mathrm{ThO}_{2}$ particles, particularly at the higher irradiation temperature. The results of these experiments indicate that ${ }^{137} \mathrm{Cs}$ and ${ }^{125} \mathrm{Sb}$ were released at the higher temperatures and burnups; however, at the lower burnups, the ${ }^{137} \mathrm{Cs}$ and ${ }^{125} \mathrm{Sb}$ inventories calculated using the procedure for ${ }^{95} \mathrm{Zr},{ }^{106} \mathrm{Ru}$, and ${ }^{144} \mathrm{Ce}$ were higher than the measured inventories. Therefore, a correction was applied to make the initial measured values correspond with the calculated values as described below.

The analyzed concentrations of ${ }^{125} \mathrm{Sb},{ }^{137} \mathrm{Cs},{ }^{106} \mathrm{Ru}$, and ${ }^{144} \mathrm{Ce}$ in the coated particles were used to obtain neutron fluxes by interpolation of the values in Tables B.6 through B.9 (Appendix B). Since ${ }^{106} \mathrm{Ru}$ and ${ }^{144} \mathrm{Ce}$ are not expected to be released from oxide fuel particles and are the next most prominent peaks in the gamma-ray spectra of these coated particles, the neutron fluxes of the individual samples 
Table 9.1. Difference between calculated and analyzed inventories of ${ }^{95} \mathrm{Zr},{ }^{106} \mathrm{Ru}$, and ${ }^{144} \mathrm{Ce}$ in Biso-coated $\mathrm{ThO}_{2}$ particles from $\mathrm{HT}-12$ through

HT-15 urradiation experıments

\begin{tabular}{|c|c|c|c|c|c|c|}
\hline \multirow[t]{2}{*}{$\begin{array}{c}\text { Sample } \\
\text { No }\end{array}$} & \multirow[t]{2}{*}{$\begin{array}{c}\text { Number of } \\
\text { particles }\end{array}$} & \multirow{2}{*}{$\begin{array}{l}\text { Irradiation } \\
\text { temperature } \\
\left.{ }^{\circ} \mathrm{C}\right)\end{array}$} & \multirow[t]{2}{*}{$\begin{array}{l}\text { Burnup }^{a} \\
\text { (\% FIMA) }\end{array}$} & \multicolumn{3}{|c|}{$\begin{array}{c}\text { Difference between } \\
\text { calculations and } \\
\text { analyses }(\%)^{b}\end{array}$} \\
\hline & & & & $\overline{{ }^{95} \mathrm{Zr}}$ & ${ }^{106} \mathrm{Ru}$ & $\overline{{ }^{144} \mathrm{Ce}}$ \\
\hline \multicolumn{7}{|c|}{ Coatıngs survived } \\
\hline НТ-12-8 & 16 & 1090 & 082 & 24 & -8 & 0 \\
\hline HT-12-13 & 16 & 1180 & 101 & 24 & -2 & 5 \\
\hline HT 12-21 & 16 & 1370 & 138 & 23 & -7 & 2 \\
\hline HT-12-26 & 15 & 1450 & 145 & 19 & 0 & 6 \\
\hline HT-13-8 & 15 & 1190 & 366 & 16 & -11 & 0 \\
\hline HT-13-13 & 15 & 1270 & 452 & 17 & -8 & 2 \\
\hline HT-13-21 & 18 & 1460 & 602 & 6 & -6 & -1 \\
\hline HT-13-26 & 19 & 1520 & 635 & 15 & -4 & 2 \\
\hline HT-14-8 & 1 & 1250 & 785 & 9 & -10 & 4 \\
\hline HT-14-13 & 2 & 1320 & 963 & 6 & -13 & 1 \\
\hline HT-14-21 & 12 & 1500 & 137 & -7 & -25 & -9 \\
\hline HT-15-13 & 1 & 1330 & 118 & 5 & -17 & 1 \\
\hline HT-15-26 & 19 & 1550 & 164 & 6 & -10 & 1 \\
\hline \multicolumn{7}{|c|}{ Coatıngs falled } \\
\hline HT-12-26 & 1 & 1450 & 145 & 26 & 5 & 12 \\
\hline HТ-13-8 & 1 & 1190 & 366 & 5 & -5 & 1 \\
\hline HT-14-8 & 14 & 1250 & 785 & 10 & -12 & 0 \\
\hline HT-14-13 & 6 & 1320 & 963 & 6 & -12 & 2 \\
\hline HT-14-21 & 3 & 1500 & 137 & -2 & -23 & -6 \\
\hline HT-15-8 & 13 & 1260 & 989 & 3 & -14 & 1 \\
\hline HT-15-13 & 7 & 1330 & 118 & 7 & -16 & 2 \\
\hline \multicolumn{7}{|c|}{ Coatings not tested or some falled and some survived } \\
\hline HT-13-29 & $18^{c}$ & 1470 & 639 & 6 & -16 & -4 \\
\hline HT 14-13 & $17^{d}$ & 1320 & 963 & 6 & -13 & 1 \\
\hline HT-14-21 & $18^{d}$ & 1500 & 137 & -3 & -22 & -7 \\
\hline HT-14-26 & $1^{c}$ & 1550 & 145 & -8 & -18 & -8 \\
\hline HT-15-13 & $16^{c}$ & 1330 & 118 & 5 & -15 & 2 \\
\hline HT-15-29 & $18^{d}$ & 1510 & 158 & -2 & -24 & -6 \\
\hline
\end{tabular}

${ }^{a}$ Burnup calculated from fission product unventories

$b_{\text {Difference }(\%)}=(C-A) / C \times 100$, where $C=$ calculated inventory and $A=$ analyzed inventory Calculations based on average neutron flux determmed from ${ }^{95} \mathrm{Zr},{ }^{106} \mathrm{Ru}$, and ${ }^{144} \mathrm{Ce}$ inventories

${ }^{c}$ Coated particles not tested by hot chlorine leach

$d_{\text {Includes particles tested and listed above plus some not tested }}$ 
ORNL OWG $76-1161$

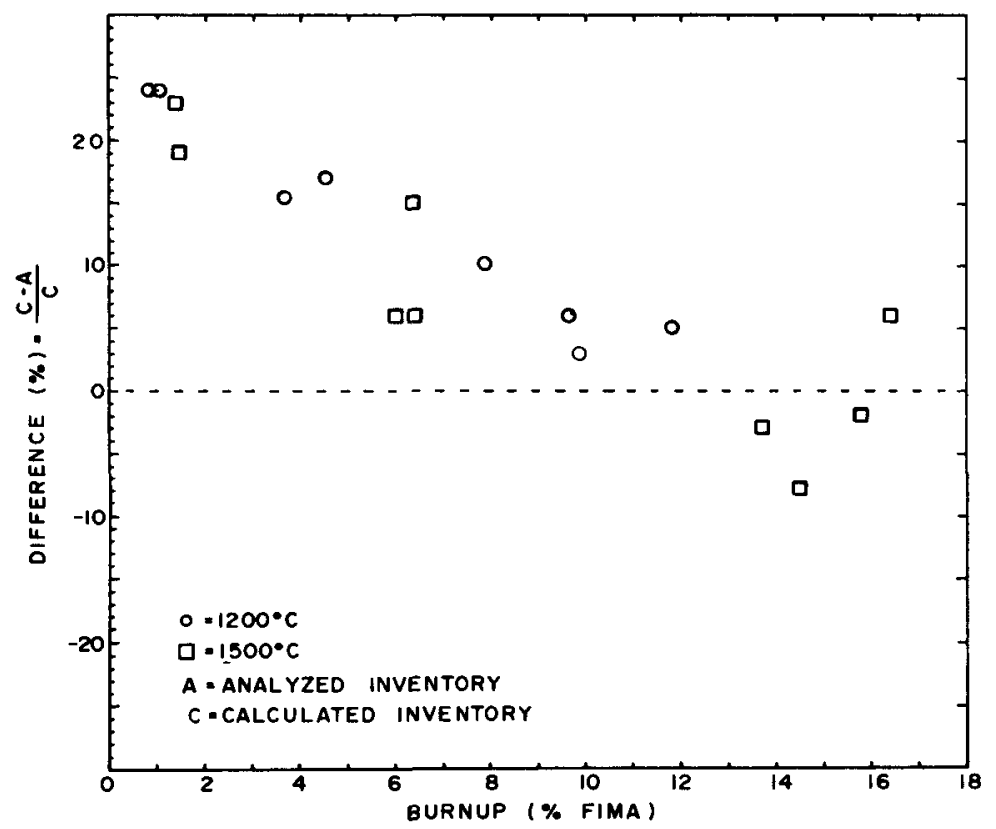

Fig. 9.1. Difference between calculated and analyzed inventories of ${ }^{95} \mathrm{Zr}$ in fertile particles from capsules HT-12 through HT-15.

ORNL DWG $76-1162$

-

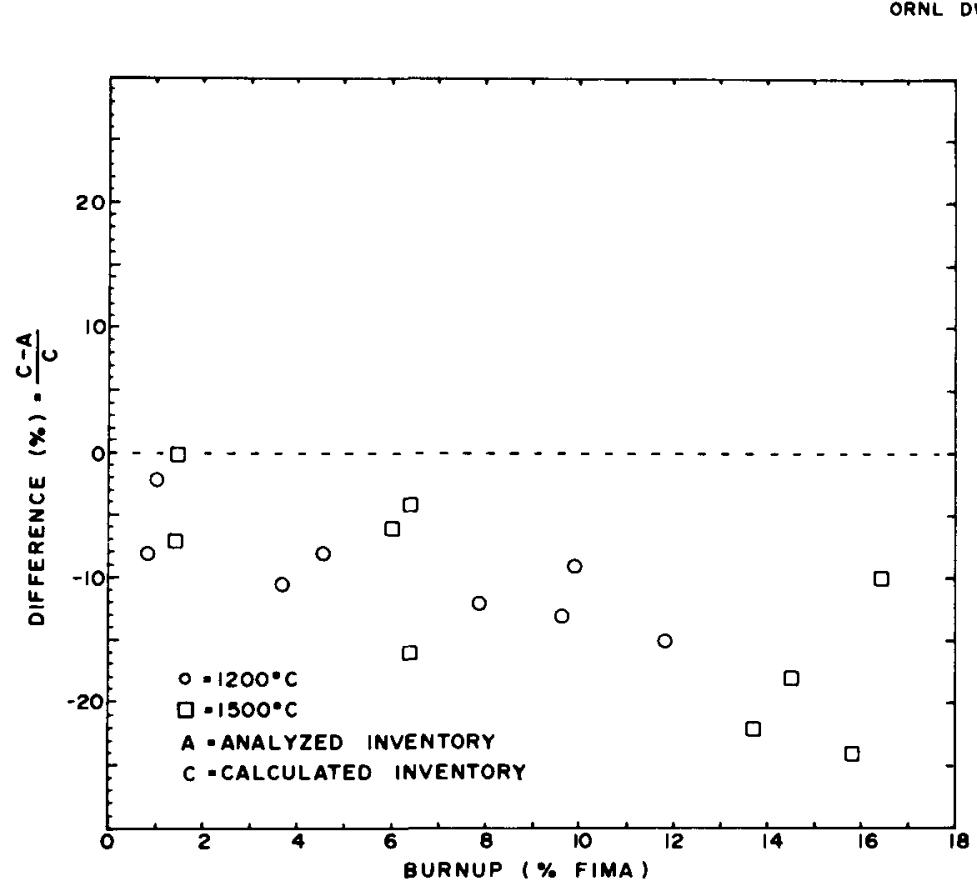

Fig. 9.2. Difference between calculated and analyzed inventories of ${ }^{106} \mathrm{Ru}$ in fertile particles from capsules HT-12 through HT-15. 


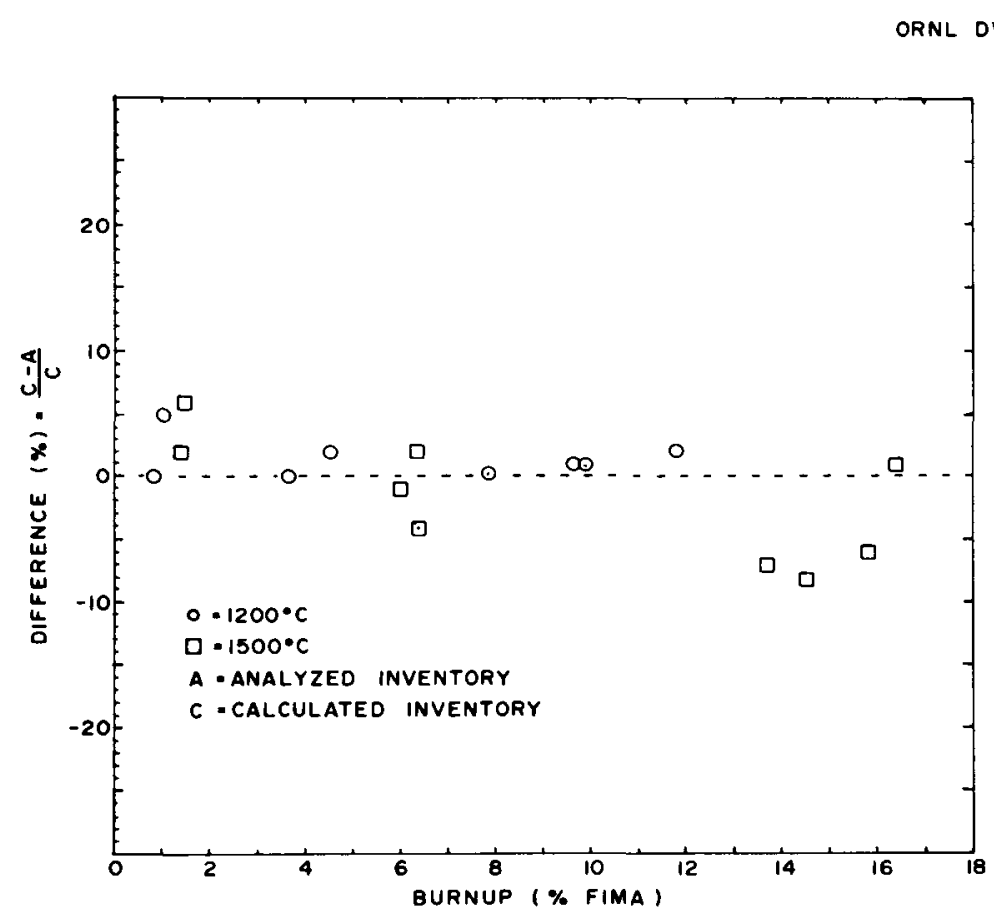

Fig. 9.3. Difference between calculated and analyzed inventories of ${ }^{144} \mathrm{Ce}$ in fertile particles from capsules HT-12 through HT-15.

used were determined from the average of the ${ }^{106} \mathrm{Ru}$ and ${ }^{144} \mathrm{Ce}$ inventories and multiplied by the average of the ratio of neutron flux determined from the ${ }^{137} \mathrm{Cs}$ and ${ }^{125} \mathrm{Sb}$ to the average of that determined from ${ }^{106} \mathrm{Ru}$ and ${ }^{144} \mathrm{Ce}$ in the low-burnup samples. These ratios were 1.07 and 1.09 respectively. These neutron fluxes were then used to determine the ${ }^{137} \mathrm{Cs}$ and ${ }^{125} \mathrm{Sb}$ produced in the coated particles. The use of the neutron flux obtained from the average ${ }^{144} \mathrm{Ce}$ and ${ }^{106} \mathrm{Ru}$ inventories in each sample, corrected by the appropriate ratios as applicable rather than use of average neutron fluxes multiplied by attenuation factors, eliminated errors due to particle size or neutron flux variations.

The fractional releases of ${ }^{137} \mathrm{Cs}$ and ${ }^{125} \mathrm{Sb}$ are listed in Table 9.2 and are plotted vs burnup in Figs. 9.4 and 9.5. The data in Fig. 9.1 show no significant loss of cesium to a burnup of about 2\% FIMA at either 1200 or $1500^{\circ} \mathrm{C}$. At $1200^{\circ} \mathrm{C}$ no loss is apparent until a burnup of $4.5 \% \mathrm{FIMA}$ is exceeded. The release of $20 \%$ of the cesium at $6 \%$ FIMA indicates that losses occur earlier at $1500^{\circ} \mathrm{C}$ and are higher with temperature and burnup, as would be expected. The effects of coating failures are difficult to assess. In most samples, all or nearly all of the coatings either survived or failed; therefore, direct comparisons are limited. Also, the time of failure cannot accurately be determined. The data show no effect of coating failure at lower burnups, but a possible higher release at the higher burnups. The data in Fig. 9.2 show an increase in ${ }^{125} \mathrm{Sb}$ release with burnup, but no definite effects of temperature or coating failure within the scatter of the data. 
Table 9.2. Loss of antimony and cesium from Biso-coated $\mathrm{ThO}_{2}$ particles in capsules HT-12 through

HT-15 during urradiation

\begin{tabular}{|c|c|c|c|c|c|}
\hline \multirow{2}{*}{$\begin{array}{c}\text { Sample } \\
\text { No }\end{array}$} & \multirow{2}{*}{$\begin{array}{c}\text { Number of } \\
\text { particles }\end{array}$} & \multirow{2}{*}{$\begin{array}{l}\text { Irradiation } \\
\text { temperature } \\
\left({ }^{\circ} \mathrm{C}\right)\end{array}$} & \multirow{2}{*}{$\begin{array}{l}\text { Burnup }^{a} \\
\text { (\% FIMA) }\end{array}$} & \multicolumn{2}{|c|}{$\operatorname{Loss}(\%)^{b}$} \\
\hline & & & & ${ }^{125} \mathrm{Sb}$ & $\sqrt{137} \mathrm{Cs}$ \\
\hline \multicolumn{6}{|c|}{ Coatıngs survived } \\
\hline HТ-12-8 & 16 & 1090 & 082 & -33 & 05 \\
\hline HT-12-13 & 16 & 1180 & 101 & -28 & 01 \\
\hline HT-12-21 & 16 & 1370 & 138 & -29 & 02 \\
\hline HT-12-26 & 15 & 1450 & 145 & -30 & 06 \\
\hline HT-13-8 & 15 & 1190 & 366 & 36 & 00 \\
\hline HT-13-13 & 15 & 1270 & 452 & 74 & -08 \\
\hline HT-13-21 & 18 & 1460 & 602 & 166 & 203 \\
\hline HT-13-26 & 19 & 1520 & 635 & 95 & 208 \\
\hline HT-14-8 & 1 & 1250 & 785 & 69 & -58 \\
\hline HT-14-13 & 2 & 1320 & 963 & 222 & 187 \\
\hline HТ-14-21 & 12 & 1500 & 137 & 236 & 424 \\
\hline HT-15-13 & 1 & 1330 & 118 & 159 & 157 \\
\hline HT-15-26 & 19 & 1550 & 164 & 342 & 290 \\
\hline \multicolumn{6}{|c|}{ Coatıngs falled } \\
\hline HT-12-26 & 1 & 1450 & 145 & -82 & -31 \\
\hline HT-13-8 & 1 & 1190 & 366 & 20 & -16 \\
\hline HT-14-8 & 14 & 1250 & 785 & 125 & 12 \\
\hline HT-14-13 & 6 & 1320 & 963 & 148 & 69 \\
\hline НТ-14-21 & 3 & 1500 & 137 & 279 & 649 \\
\hline HT-15-8 & 13 & 1260 & 989 & 126 & 394 \\
\hline HT-15-13 & 7 & 1330 & 118 & 181 & 512 \\
\hline \multicolumn{6}{|c|}{ Coatings not tested or some falled and some survived } \\
\hline HT-13-29 & $18^{c}$ & 1470 & 639 & 95 & 66 \\
\hline HT-14-13 & $17^{d}$ & 1320 & 963 & 147 & 106 \\
\hline HT-14-21 & $18^{d}$ & 1500 & 137 & 260 & 459 \\
\hline HT-14-26 & $1^{c}$ & 1550 & 145 & 240 & 595 \\
\hline HT-15-13 & $16^{c}$ & 1330 & 118 & 182 & 472 \\
\hline HT-15-29 & $18^{d}$ & 1510 & 158 & 272 & 553 \\
\hline
\end{tabular}

${ }^{a}$ Burnup calculated from fission product inventories

${ }^{b}$ Loss $(\%)=(C A) / C \times 100$, where $C=$ calculated inventory and $A$ =analyzed inventory Calculations based on ${ }^{125} \mathrm{Sb}$ and ${ }^{137} \mathrm{Cs}$ inventories in low-temperature low-burnup samples (see text)

${ }^{c}$ Includes coated particles tested and listed above

${ }^{d}$ Coated partıcles not tested by hot chlorine leaching plus some not tested

\subsection{Cesium, Antimony, and Europium Release from Bare $\mathrm{ThO}_{2}$ Kernels During \\ Postirradiation Anneals}

The experiments described in this section were conducted to determine the release rate of cesium from the kernels and to obtain approximate diffusion coefficients Kernels were separated from the coated particles and were annealed at $1400^{\circ} \mathrm{C}$ The annealing system and procedure have been described previously. ${ }^{1,2}$ Eight tungsten tubes were inserted in holes in a graphite crucible and heated by induction. Each tube contained one kernel The tubes were removed at various intervals, the kernels were removed, and the tubes and kernels were analyzed for ${ }^{137} \mathrm{Cs}$ products, using a sodium iodide gamma-ray detector. 
ORNL DWG. 76-1165

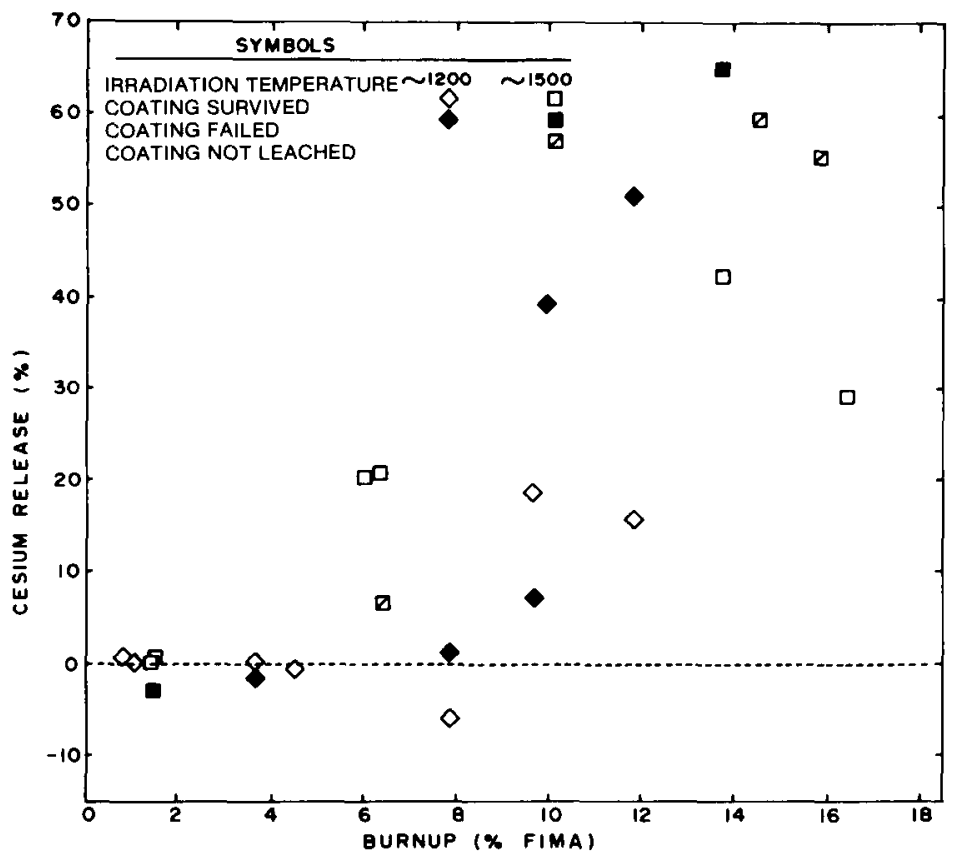

Fig. 9.4. Release of ${ }^{137} \mathrm{Cs}$ from Biso-coated $\mathrm{ThO}_{2}$ particles during irradiation in capsules HT-12 through HT-15.

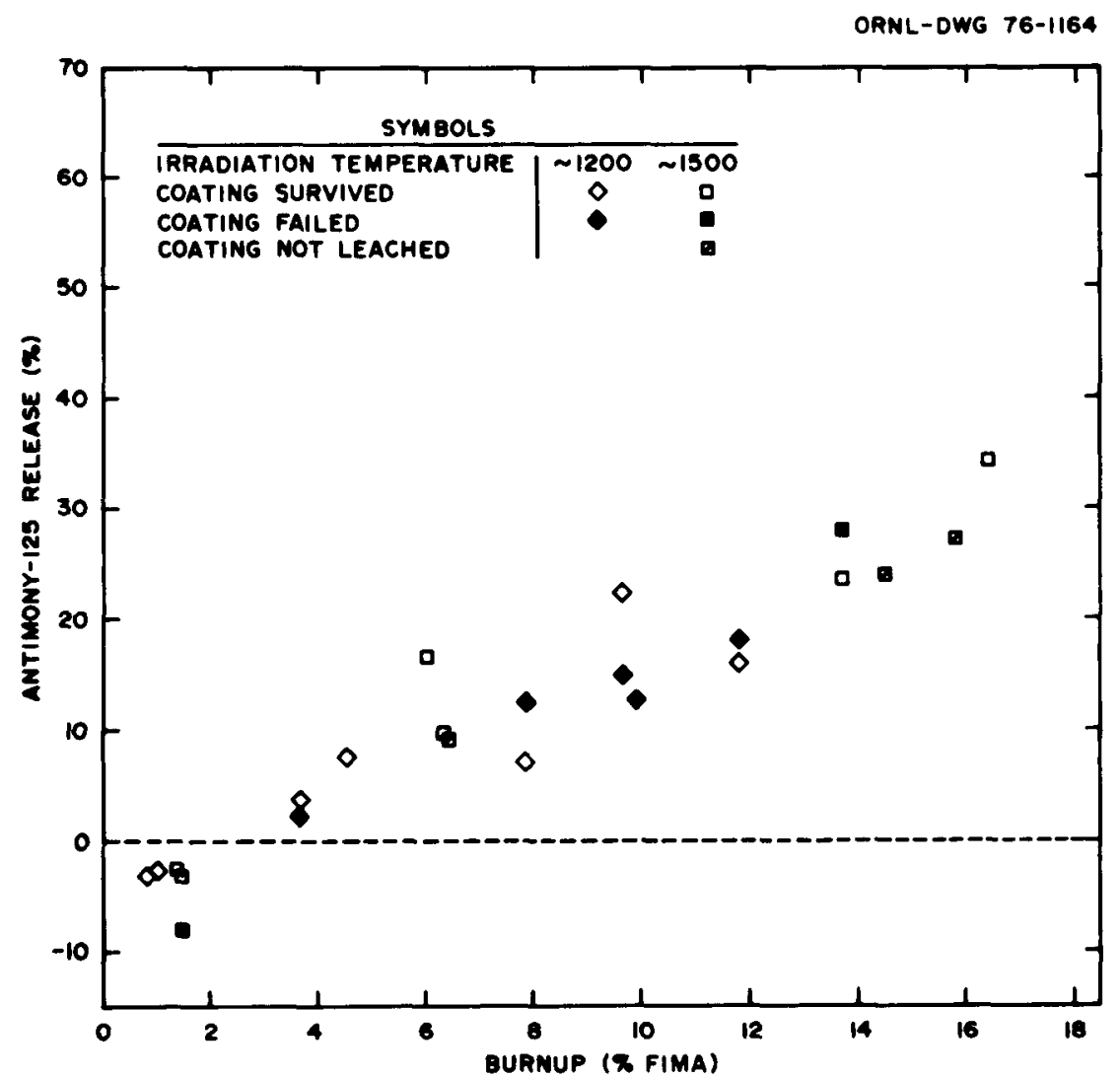

Fig. 9.5. Release of ${ }^{125} \mathrm{Sb}$ from Biso-coated $\mathrm{ThO}_{2}$ particles during irradiation in capsules HT-12 through HT-15. 
The kernels were then replaced in the tubes, and the anneal was continued. Peaks for ${ }^{125} \mathrm{Sb}$ and ${ }^{134} \mathrm{Cs}$ were found and subtracted to obtain accurate ${ }^{137} \mathrm{Cs}$ analyses, but the ${ }^{125} \mathrm{Sb}$ peak was not distinct enough for accurate ${ }^{125} \mathrm{Sb}$ analyses. However, after the annealing series ended, the kernels and tubes were analyzed on another system with a germanium detector in order to obtain the fraction of ${ }^{125} \mathrm{Sb}$ and ${ }^{154} \mathrm{Eu}$ released and to verify the ${ }^{137} \mathrm{Cs}$ release values. After annealing the kernels for $684 \mathrm{hr}$ at $1400^{\circ} \mathrm{C}$, the cesium release from kernels taken from HT-12-8, HT-12-13, HT-13-8, and HT-13-13 was less than 1\% of the total in the kernels at the beginning of the anneal. The accumulative cesium release fractions at various times are given in Table 9.3. The slope and intercept for a least-squares fit of the data vs time, the kernel diameters, and the ${ }^{137} \mathrm{Cs}$ in the separated coatings are also presented.

A typical plot of cesium release vs annealing time is shown in Fig. 9.6. The line on the graph represents a least-squares fit of the data. From the slope of the line and the average radii of the kernel, the diffusion coefficient $(D)$ was obtained by the equation

$$
D \cong \frac{F^{2} a^{2}}{36} \frac{\pi}{t}
$$

where

$F=$ fraction of cesium released in time $t$,

$a=$ radius of the kernel.

ORNL DWG. $76-1158$

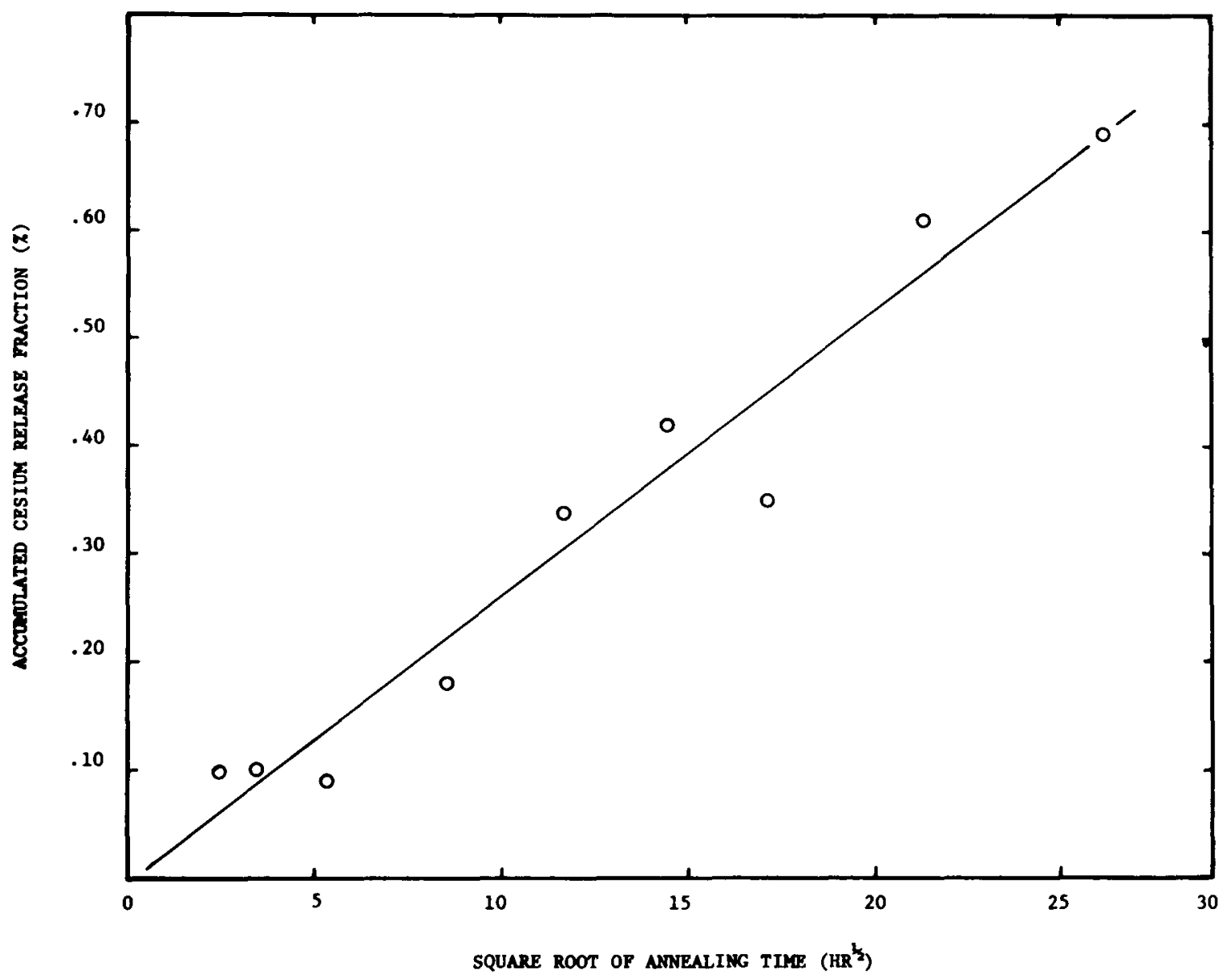

Fig. 9.6. Cesium release from bare $\mathrm{ThO}_{2}$ kernel during postirradiation anneal at $1400^{\circ} \mathrm{C}$. 
Table 9.3. Cesium release from bare kernels of $\mathrm{ThO}_{2}$ during postirradiation anneals at $1400^{\circ} \mathrm{C}$

\begin{tabular}{|c|c|c|c|c|c|c|c|c|c|}
\hline & \multirow{2}{*}{$\begin{array}{l}\text { Time } \\
(\mathrm{hr})\end{array}$} & \multicolumn{8}{|c|}{ Capsule (\% collected) } \\
\hline & & HT-12-8-1 & HT-12-8-2 & HT-12-13-1 & HT-12-13-2 & HT-13-8-1 & HT-13-8-2 & HT-13-13-1 & HT-13-13-2 \\
\hline & 6 & 0.17 & 0.019 & 0.023 & 0.067 & 0.10 & 0.02 & 0.06 & 0.09 \\
\hline & 12 & 0.18 & 0.020 & 0.024 & 0.078 & 0.10 & 0.02 & 0.07 & 0.10 \\
\hline & 28 & 0.19 & 0.021 & 0.029 & 0.080 & 0.09 & 0.02 & 0.05 & 0.09 \\
\hline & 72 & 0.20 & 0.028 & 0.047 & 0.10 & 0.18 & 0.10 & 0.16 & 0.15 \\
\hline & 136 & 0.21 & 0.018 & 0.054 & 0.12 & 0.34 & 0.26 & 0.25 & 0.18 \\
\hline & 208 & 0.24 & 0.026 & 0.069 & 0.12 & 0.42 & 0.38 & 0.35 & 0.28 \\
\hline & 293 & 0.22 & 0.034 & 0.083 & 0.14 & 0.35 & 0.32 & 0.50 & 0.35 \\
\hline & 452 & 0.26 & 0.031 & 0.082 & 0.15 & 0.61 & 0.56 & 0.61 & 0.45 \\
\hline & 684 & 0.27 & 0.047 & 0.130 & 0.17 & 0.69 & 0.66 & 0.92 & 0.67 \\
\hline Intercept ${ }^{a}(\%)$ & $f_{0}$ & 0.165 & 0.015 & 0.0090 & 0.0615 & -0.0057 & -0.0935 & -0.106 & -0.0245 \\
\hline Slope $^{a}(\% / \sqrt{h r})$ & $m$ & $4.138 \mathrm{E}-3$ & $9.816 \mathrm{E}-4$ & $4.174 \mathrm{E}-3$ & $4.276 \mathrm{E}-3$ & $2.657 \mathrm{E}-2$ & $2.885 \mathrm{E}-2$ & $3.555 \mathrm{E}-2$ & $2.339 \mathrm{E}-2$ \\
\hline Kernel diam (cm) & $k$ & $381 E-4$ & $394.5 \mathrm{E}-4$ & $501.0 \mathrm{E}-4$ & $494.0 \mathrm{E}-4$ & $403.0 \mathrm{E}-4$ & $396.2 \mathrm{E}-4$ & $500 E-4$ & $501.5 \mathrm{E}-4$ \\
\hline $\begin{array}{l}\text { Fraction in } \\
\text { coatings } b(\%)\end{array}$ & $f_{a}$ & 15 & 4 & 2 & 5 & 6 & 3 & 3 & 8 \\
\hline
\end{tabular}

${ }^{a}$ Slope and intercept from least-squares fit of data to equation $f=f_{0}+m t^{1 / 2}$, where $f=$ fraction released.

${ }^{b} f_{a}(\%)=(P-K) / P \times 100$; here $P$ is the total cesium in the particle before grinding, and $K$ is the amount in the kernel. 
This equation, adapted from Booth and Rymer, ${ }^{3}$ is good for an approximation up to a release of $20 \%$ The use of the kernel radius instead of the unknown radius of the grains in the kernel will introduce some error, and the calculated values for $D$ will be larger than the true values Diffusion coefficients for cesium in the eight kernels are listed, together with the total cesium, antımony, and europium release at $684 \mathrm{hr}$ in Table 94

Another annealing experiment on bare kernels irradiated to higher burnups from capsules HT-14 and HT-15 was attempted, however, most of the kernels disintegrated on heatup The anneal will contınue on four remaining kernels

\begin{tabular}{|c|c|c|c|c|}
\hline \multirow{2}{*}{$\begin{array}{c}\text { Coated-particle } \\
\text { No }\end{array}$} & \multicolumn{3}{|c|}{$\begin{array}{c}\text { Fraction released } \\
\text { in } 684 \mathrm{hr}(\%)\end{array}$} & \multirow{2}{*}{$\begin{array}{l}\text { Cesium diffusion } \\
\text { coefficient }\left(\mathrm{cm}^{2} / \mathrm{sec}\right)\end{array}$} \\
\hline & ${ }^{137} \mathrm{Cs}$ & ${ }^{125} \mathrm{Sb}$ & $1{ }^{154} \mathrm{Eu}$ & \\
\hline НT-12-8-1 & 027 & 120 & 00 & $15 \times 10^{-17}$ \\
\hline HT-12-8-2 & 0047 & 076 & 00 & $91 \times 10^{-19}$ \\
\hline HT 12-13-1 & 0130 & 521 & 14 & $26 \times 10^{-17}$ \\
\hline HT 12-13-2 & 017 & 049 & 00 & $27 \times 10^{-17}$ \\
\hline HT-13-8-1 & 069 & 1735 & 114 & $70 \times 10^{-16}$ \\
\hline HT $13-8-2$ & 066 & 1635 & 94 & $79 \times 10^{-16}$ \\
\hline HT 13-13-1 & 092 & 1926 & 156 & $19 \times 10^{-15}$ \\
\hline HT-13-13-2 & 067 & 2089 & 205 & $83 \times 10^{-16}$ \\
\hline
\end{tabular}

\subsection{Cesium Concentration Profiles in Pyrocarbon Coatings}

Cesium concentration profiles in coatıngs of particles from capsules HT-12 and HT-13 have been obtained by grinding The apparatus used is shown in Fig 97 Three separate motions are provided to ensure even grindıng and to maintain spheroidicity The coatıngs are removed in steps After each cut, the abrasive disk is removed for analysis and replaced with new abrasive paper A typical profile of cesium concentration in the coating of a particle from HT-13-8 is shown in Fig 98 For comparison, a typical cesium concentration profile for a coated $\mathrm{UO}_{2}$ particle irradiated to a higher burnup and which demonstrated constant-potential cesium transport is shown in Fig 99 The lower concentrations shown in Fig 98 reflect the low cesium release from this particle The shape of the profile with a higher concentration at the outer boundary would indicate a variation in cesium solubility in the coating with radial position This variation in coating characteristics with radial position is also seen in the grinding rate as a function of radial position plotted in Fig 910 In this graph, the volume removed per unit time represents the grinding rate while the grinder was maintained at constant conditions of applied voltage and lubrication However, the grinder was not designed to maintain constant grinding rates, also, there is a possible variation of grinding rate with particle diameter inherent in the grinding process Therefore, the curves can be used only for qualitative comparisons The graph shows that the coatings of the batch OR-1849 particles were softer at the outer boundary This effect was not as pronounced in the OR-1840 particles The rise in grinding rate in the outer coatıng at the buffer interface might be due partially to errors in determining this boundary The graph shows a decrease in grinding rate in the buffer as the kernel is approached in the OR-1849 particles The buffer broke away in the smaller OR-1840 particles, preventıng us from obtainıng profile information in the buffers of these coated particles 
ORNL-DWG $74-13370$
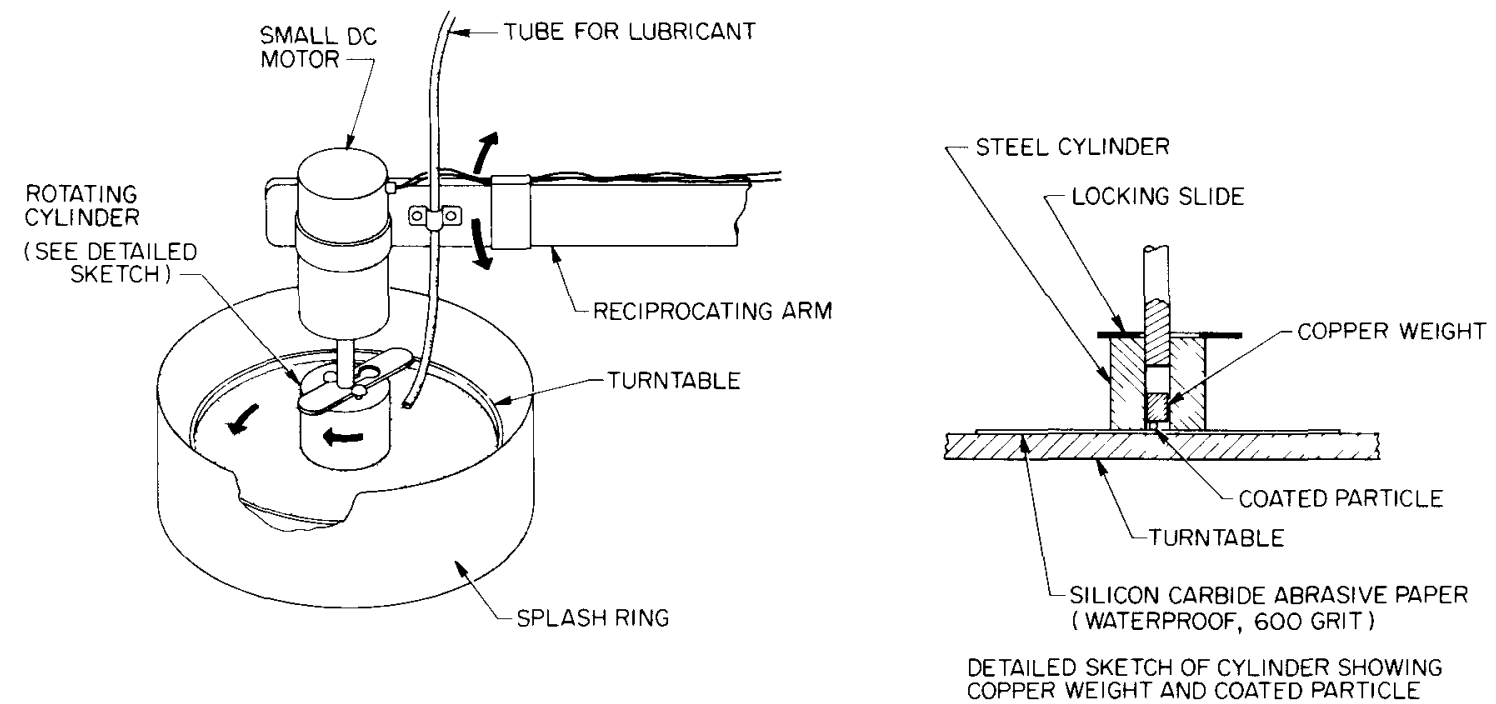

Fig. 9.7. Coated particle grinder.

ORNL DWG. 76-1159

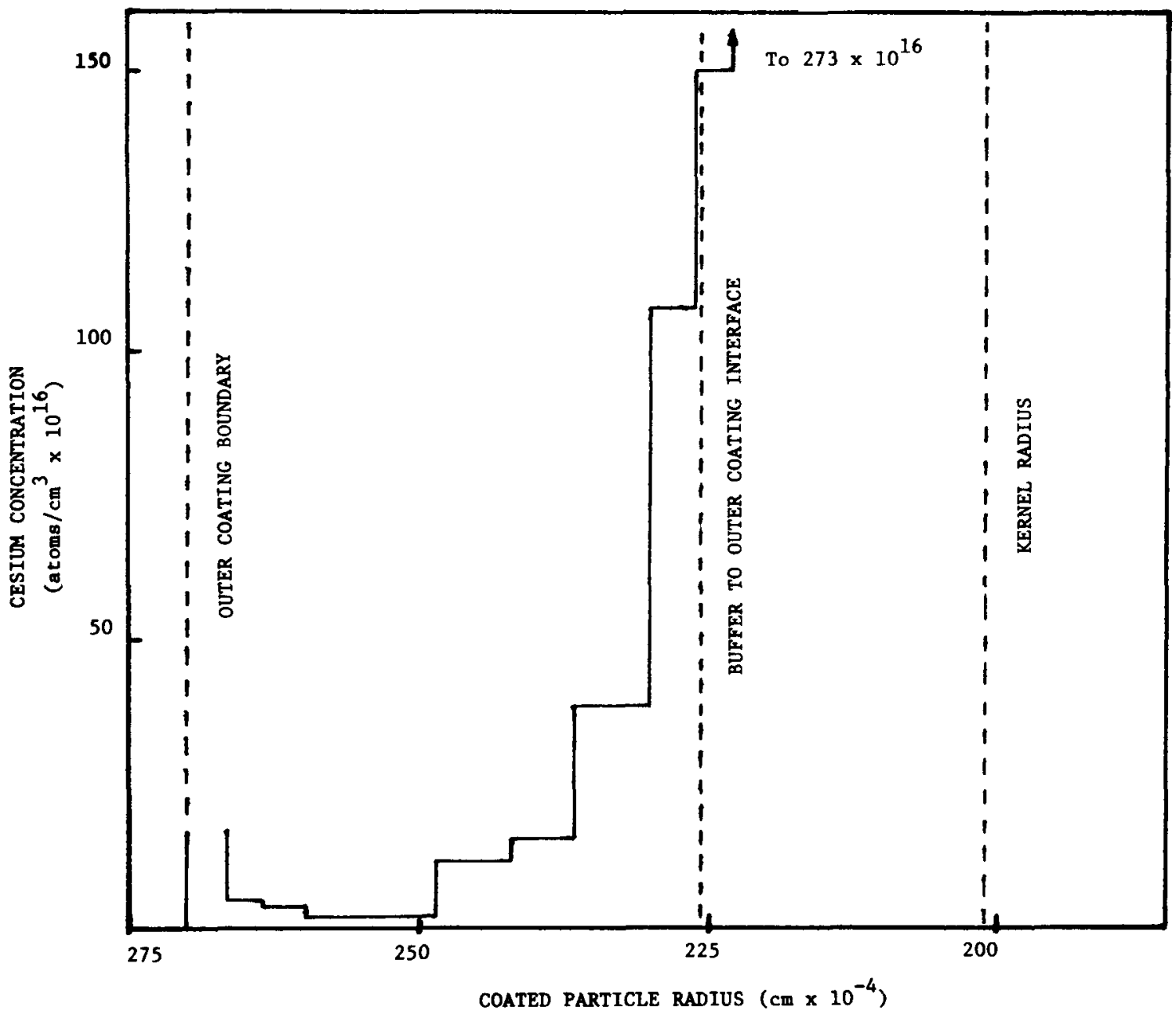

Fig. 9.8. Cesium concentration in coating of particle from HT-13-8. 


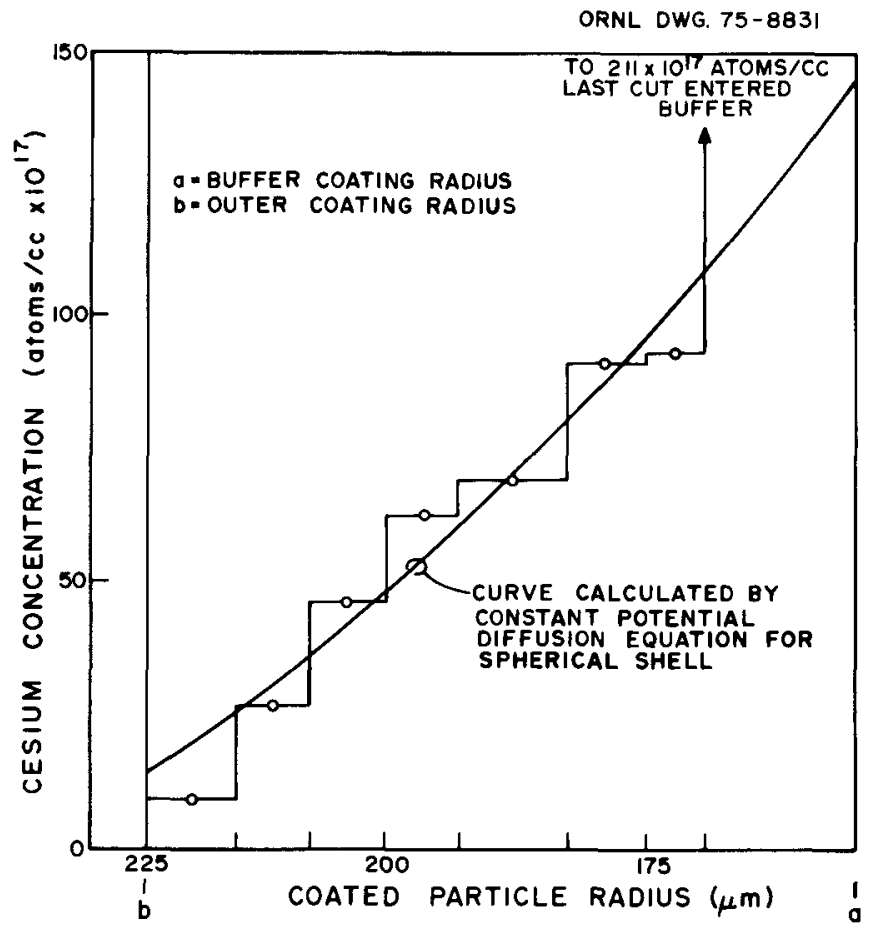

Fig. 9.9. Cesium concentration profile in pyrocarbon coating of $\mathrm{UO}_{2}$ particle irradiated to $11 \%$ FIMA and annealed 30 hr at $1400^{\circ} \mathrm{C}$.

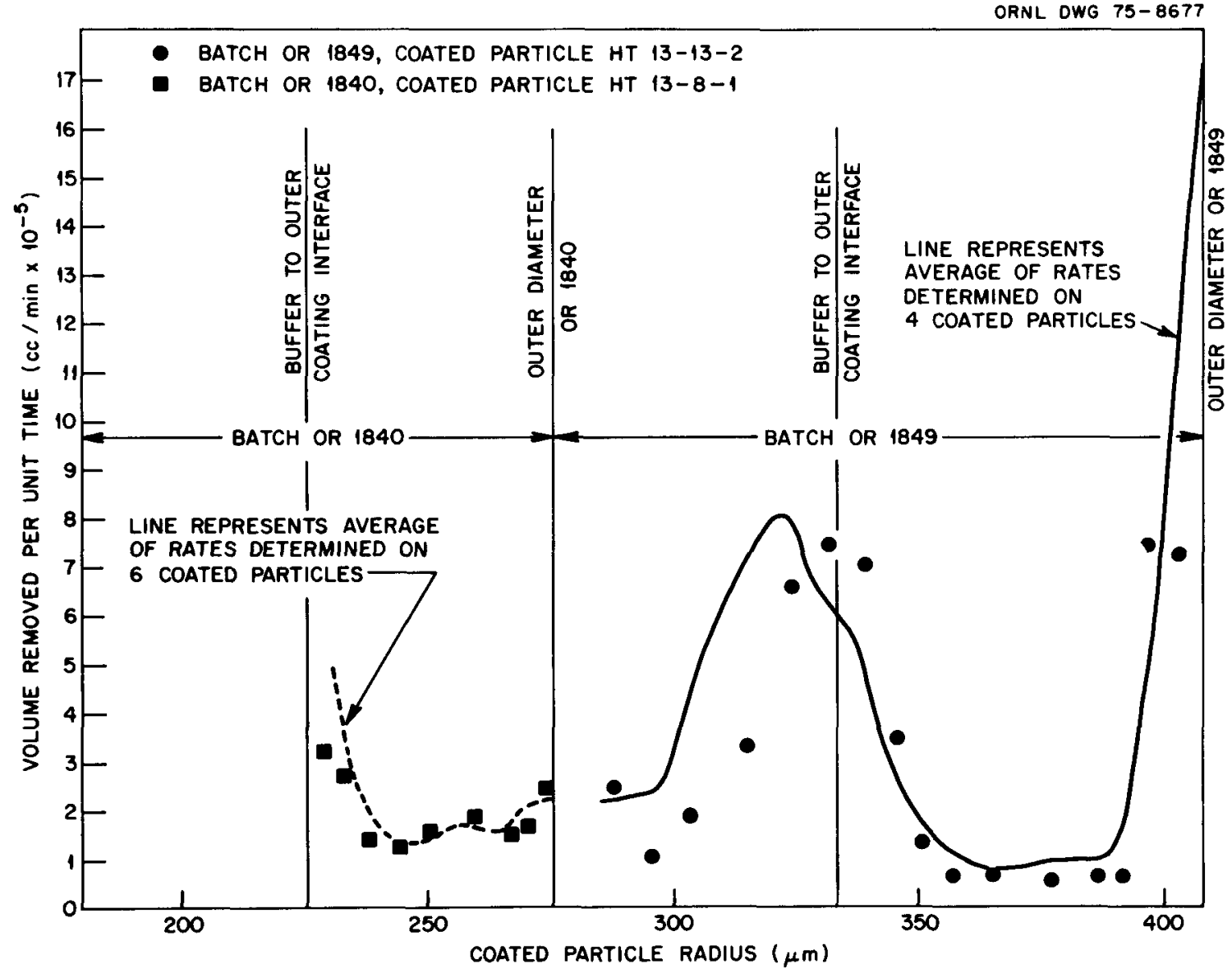

Fig. 9.10. Coated particle grinding rates. 


\subsection{Summary and Discussion of Fission Product Release Experiments on Biso-Coated $\mathrm{ThO}_{2}$ Particles from Batches OR-1838, OR-1840, and OR-1849}

Some of the conclusions to be drawn from the fission product analyses after irradiation may be in doubt because of several inconsistencies. The ratios of analyzed-to-measured inventories of the various fission products do not agree, and these ratios increase (or the apparent release decreases) with burnup for ${ }^{95} \mathrm{Zr}$ and ${ }^{106} \mathrm{Ce}$, which is not as expected. These problems are probably caused by the use of incorrect input data in the calculated values. Further research is necessary to obtain correct yields and reaction rates for the HFIR-HT experiments. The decrease and negative values in the apparent release of ${ }^{95} \mathrm{Zr}$, ${ }^{106} \mathrm{Ru}$, and ${ }^{144} \mathrm{Ce}$ as burnup increases indicate the probable retention of these fission products to burnups of $16 \%$ and temperatures to $1550^{\circ} \mathrm{C}$ in the coated particles examined. The burnups used here are the more conservative values obtained from the fission product inventories.

The calculations for the release of ${ }^{125} \mathrm{Sb}$ and ${ }^{137} \mathrm{Cs}$ were based on the neutron fluxes determined from the ${ }^{106} \mathrm{Ru}$ and ${ }^{144} \mathrm{Ce}$ inventories in individual samples and were normalized to make the values of release from low-burnup, low-temperature samples equal to zero. This procedure avoided some of the above problems, since the ratio of the long-lived fission products is not greatly changed with neutron flux or burnup, and the effect of variations in particle size is canceled.

The release of ${ }^{125} \mathrm{Sb}$ increases almost linearly with burnup from zero at about $2 \%$ FIMA to a value of about $35 \%$ release at $16 \%$ FIMA. No effect of temperature or coating failures is apparent. The release of ${ }^{137} \mathrm{Cs}$, on the other hand, seems to begin at about $2 \%$ FIMA for the high-temperature samples and between 5 and $8 \%$ FIMA for the low-temperature samples. Coating failures have no effect at low burnups but seem to cause a higher release at higher burnups. The cesium release increases with burnup to between 30 to $60 \%$ at $16 \%$ FIMA in the high-temperature samples.

The lack of an effect of temperature on the release of ${ }^{125} \mathrm{Sb}$ is puzzling. The absence of an effect of coating failures can be explained if the kernel provides the control of the release. On the other hand, if the coating fails on an oxide fuel particle, the loss of $\mathrm{CO}$ would allow a reaction between the fuel and the pyrocarbon at high temperatures. ${ }^{4}$ This should cause increased fission product release. The increase in release with burnup for both ${ }^{125} \mathrm{Sb}$ and ${ }^{137} \mathrm{Cs}$ is probably due to changes in the kernel. Previous postirradiation experiments ${ }^{1}$ with Biso-coated $\mathrm{UO}_{2}$ particles irradiated to 11 and $22 \%$ FIMA, respectively, showed little effect of burnup on the diffusion of cesium in the coatings and a trapped fraction of up to about $33 \%$ at $1250^{\circ} \mathrm{C}$ in the lower-burnup samples. Other experiments in the same series indicated a trapped fraction of about $95 \%$ of the cesium in Biso-coated $\mathrm{ThO}_{2}$ particles irradiated to $3.5 \%$ FIMA and annealed at $1400^{\circ} \mathrm{C}$. It is postulated that a certain fraction of cesium is available in the buffer coating and in accessible regions of the kernel, whereas the rest must diffuse at a much slower rate from more inaccessible sites within the kernel. It is reasonable to expect that the trapped fraction will change with burnup because of increased porosity, changes in structure, and replacement of fuel with certain fission products as burnup increases. The increased cesium release in particles with defective coatings indicates some control of the release by nondefective coatings.

The low cesium release during irradiation at about $1250^{\circ} \mathrm{C}$ to burnups up to about $5 \%$ and an irradiation time of about $2000 \mathrm{hr}$ in these experiments agrees with the postirradiation experiment cited above, where $95 \%$ of the cesium remained trapped at $1400^{\circ} \mathrm{C}$. In these cases, most of any cesium released is due to fission fragment recoils. The annealing experiments on Biso-coated $\mathrm{UO}_{2}$ particles showed that the breakthrough time for cesium to penetrate LTI pyrocarbon coatings of similar thickness was about $300 \mathrm{hr}$.

The release of ${ }^{137} \mathrm{Cs}$ and ${ }^{125} \mathrm{Sb}$ from bare kernels during anneals at $1400^{\circ} \mathrm{C}$ also showed an effect of burnup. No rapid release of an "available" fraction of cesium was demonstrated here, contrary to that 
observed in previous experiments ${ }^{1}$ on bare $\mathrm{UO}_{2}$-coated particles irradiated to higher burnups. The available fraction here consists of the cesium in the coatings plus whatever was released during irradiation. Although the absolute release during irradiation could not be determined exactly, the near-zero relative release over the $2000-\mathrm{hr}$ period to a burnup of $5 \%$ is supported by the postirradiation experiment at $1400^{\circ} \mathrm{C}$ in the bare kernels, where $<1 \%$ of the cesium was released in 684 $\mathrm{hr}$. The fraction of cesium in the coatings removed was approximately $5 \%$. The higher value in HT-12-81 was caused by accidentally grinding slightly into the surface of the kernel during removal of the coating. In many cases the buffer layer was removed by pressure applied by hand after the outer coatings were removed. In others, the buffer layer broke away during grinding, resulting in some abrasion to the kernel. These differences in the kernel surfaces may account for some of the different release fractions observed during the anneals of identical particles.

The approximate diffusion coefficients calculated here for cesium diffusion in the kernels describe the rate of release of the "trapped fraction." The diffusion coefficients in the kernel increase with burnup. At higher burnups and temperatures, the entire cesium inventory becomes available to the coating; thus the slower rate of transport through the coating becomes dominant. At higher concentrations the cesium release may be limited by a constant potential at the inner boundary of the outer coating.'

The low cesium concentration profiles in the outer coating also confirm that the cesium release in the lower-burnup, lower-temperature samples of these experiments is kernel-controlled.

To date, there have been no reports of significant amounts of ${ }^{125} \mathrm{Sb}$ in the coolant circuits of test reactors. This may be due to the low yield for ${ }^{125} \mathrm{Sb}, 0.025 \%$ from ${ }^{235} \mathrm{U}$, and $0.11 \%$ from ${ }^{233} \mathrm{U}$. The larger yield from ${ }^{233} \mathrm{U}$ may account for the fact that the ${ }^{125} \mathrm{Sb}$ is noticeable in the fission product release experiments on thoria fuel, whereas it was rarely found in experiments on enriched $\mathrm{UO}_{2}$. The fission products ${ }^{137} \mathrm{Cs},{ }^{90} \mathrm{Sr}$, and ${ }^{110} \mathrm{Ag}$ are generally regarded as the major hazards. Silver has not been detected in the coated particles from these experiments.

\section{References}

1. M. T. Morgan, H. J. de Nordwall, and R. L. Towns, Release of Fission Products from Pyrocarbon-Coated HTGR Fuel Particles During Postirradiation Anneals, ORNL/TM-4539 (December 1974).

2. M. T. Morgan and R. L. Towns, Techniques and Apparatus for Inspection, Handling, and Annealing Highly Radioactive Fuel Microspheres, ORNL/TM-2495 (March 1969).

3. A. H. Booth and G. T. Rymer, Determination of the Diffusion Constant of Fission Xenon in $\mathrm{UO}_{2}$ Crystals and Sintered Compacts, Report No. CRDC-721 (September 1957).

4. J. R. Piazza and M. J. Sinnott, "High-Temperature Phase Equilibria in the System CarbonOxygen-Uranium," J. Chem. Eng. Data 7(4), 451-57 (October 1962). 


\section{CHARACTERIZATION OF PYROCARBON COATINGS}

Characterization measurements were made on the proycarbon (PyC) LTI coating of archives of Biso-coated fuel particles. Selected batches, OR-1749, OR-1838, and OR-1849, were examined by using optical anisotropy (OPTAF), plasma oxidation, and transmission electron miscroscopy (TEM) techniques. Each of these batches showed excellent survival rates, per visual inspection, in capsules HT12 through HT-15, with the exception of batch OR-1749 in capsule HT-14 (Table 4.1). However, some of these coated particles developed permeability during irradiation. Investigations were conducted at ORNL and at KFA-IRW, Jülich, Republic of Germany.

\subsection{Optical Anisotropy}

Special metallographic samples of particles from the HT-12 through HT-15 series were prepared for OPTAF measurements. After OP'TAF measurements were completed at ORNL, the particles were shipped to Jülich for additional examination. Seventeen particles from each of the batches were arranged in a $4 \times 4$ array in a metallographic mount with the seventeenth particle serving as an index mark. This arrangement provided for identification of five specific particles measured in each sample set. The optical measurements included maximum and minimum relative reflected intensities used for calculation of OPTAF values and also absolute reflectivities.

The twofold symmetry OPTAF values obtained by the two laboratories using air objectives are shown in Table 10.1. The agreement between the OPTAF values obtained for a specific ORNL coating by the two laboratories is well within the ORNL estimated variance of \pm 0.015 OPTAF unit for values in the range of 1.03 to 1.00 . These results indicate that for a specific PyC specimen, the ORNL and KFAIRW values are essentially identical.

\begin{tabular}{|c|c|c|}
\hline \multirow{2}{*}{$\begin{array}{c}\text { Particle } \\
\text { designation }\end{array}$} & \multicolumn{2}{|r|}{ OPTAF } \\
\hline & $\mathrm{ORNL}^{b}$ & $(\mathrm{KFA}-\mathrm{IRW})^{b, c}$ \\
\hline OR-17 & 1.03 & 1.0 \\
\hline OR-1838 & 1.02 & \\
\hline OR-1849 & 1.02 & 1.033 \\
\hline \multicolumn{3}{|c|}{$\begin{array}{l}{ }^{a} \text { Based on maximum and minimum } \\
\text { reflectivity using polarizer only, wave- } \\
\text { length }=5470 \AA \text {. } \\
{ }^{b} \text { Midradius value of PyC coating. } \\
{ }^{c} \text { Measurements made on Leitz MPV-II } \\
\text { system. }\end{array}$} \\
\hline
\end{tabular}

\subsection{Plasma Oxidation}

The technique for selective etching of $\mathrm{PyC}$ fuel particle coatings by an $\mathrm{rf}$-excited oxygen plasma was developed such that etch features during etching could be resolved optically at magnifications in excess of 500×. Standard epoxy metallographic mounts containing the fuel particles of interest were polished to expose the midplane of the particle coatings. The polished coatings were first used for OPTAF measurements and then were etched in the oxygen plasma. The etcher contains two chambers, and the rf power (at $13.5 \mathrm{MHz}$ ) in each chamber was maintained at $20 \mathrm{~W}$, with the oxygen pressure at 0.75 torr. A 
detailed description of this technique is described in ref. 2. The technique employed by KFA-IRW is similar except that their etcher contains more than two chambers.

Observations of polished surfaces of various $\mathrm{PyC}$ coatings in polarized light at about $60 \times$ indicate that they consist of two optically discernible varieties of carbon. One is optically anisotropic and is visible at $500 \times$ or above as very small regions of optical activity. These small regions exhibit four maxima of reflected intensity during a $360^{\circ}$ rotation of the polarization vector in the light beam relative to some reference direction on the $\mathrm{PyC}$ midplane surface. The deposition and apparent concentration of these optically active regions vary greatly in $\mathrm{PyC}$ coatings produced in different sized coaters and under various coating conditions. The other variety of carbon present in the coatings is optically inactive by microscopic observation under crossed polars. In some cases the regions containing this carbon exist over distances of several micrometers.

Oxidation occurs most rapidly in coating regions where the optically inactive carbon is concentrated in the LTI PyC. These regions are designated ROC (readily oxidizable carbon). The regions where the optical domains are concentrated oxidize relatively slowly, and these regions are designated POC (poorly oxidizable carbon). This differential in oxidation rates produces the surface relief in an originally polished $\mathrm{PyC}$ surface that can be observed using dark-field illumination. The relief structure produced by plasma oxidation thus provides an indication of the locations of regions having high concentrations of the optically active carbon in the coating. Workers at KFA have reported that the geometric disposition and concentration of the less oxidizable carbon have an important bearing on the fast-neutron damage resistance of a PyC LTI coating. Coating structures in which this optically active carbon is present in continuous spherical shells in the coating have been reported by KFA to be much more sensitive to failure because of fast-neutron damage than structures in which the two varieties of carbon, deduced from etching results, are distributed in such a way that the poorly oxidizing carbon does not form continuous shells. This concept has been confirmed through plasma oxidation and irradiation data for coating types irradiated in HT-17 through HT-19. ${ }^{3}$

Coating OR-1849, which contained a $75-\mu$ m-thick LTI, was examined by plasma oxidation at ORNL and at KFA. Figure $10.1[(a)$ and $(b)]$ shows dark-field photomicrographs of KFA's results at $500 \times$ and $1000 \times$ respectively. Figure 10.2 is a dark field of OR NL's results at $500 \times$. In each case it was found that coating OR-1849 contained a large quantity of ROC and the distribution was homogeneous, with the exception of the layer adjacent to the buffer layer. This etch structure agrees well with the survival criteria discussed previously.

Coating OR-1749, which had a nominal LTI design thickness of about $36 \mu \mathrm{m}$, was also examined by ORNL and KFA. Figure 10.3 [parts $(a)$ and $(b)$ ] shows dark-field photomicrographs of KFA's results on this coating at $500 \times$ and $1000 \times$ respectively. Figure 10.4 is a similar photomicrograph of ORNL's results at $500 \times$. As can be seen, this coating exhibited wide ROC bands running nearly continuously through the coating. The regions between the bands are made up almost entirely of $F(, C$. This coating typically exhibited a structure having two or three bands of POC alternating with bands of ROC along the coating radius. In contrast to the survival criteria presented earlier, this coating type showed good irradiation performance (per visual inspection) in spite of the banded structure.

Coating OR-1838, which had a nominal LTI thickness of $64 \mu \mathrm{m}$, was examined by ORNL only. Figure 10.5 is a photomicrograph of ORNL's results at $500 \times$. This coating exhibited an etch structure that consisted of two or three zones of finely spaced bands of POC with alternate bands of ROC. Some particle coatings contained two of the clustered bands, whereas others exhibited three during the etching procedure. This coating also showed good survival (per visual inspection) in capsules H'T-12 through HT-14. 

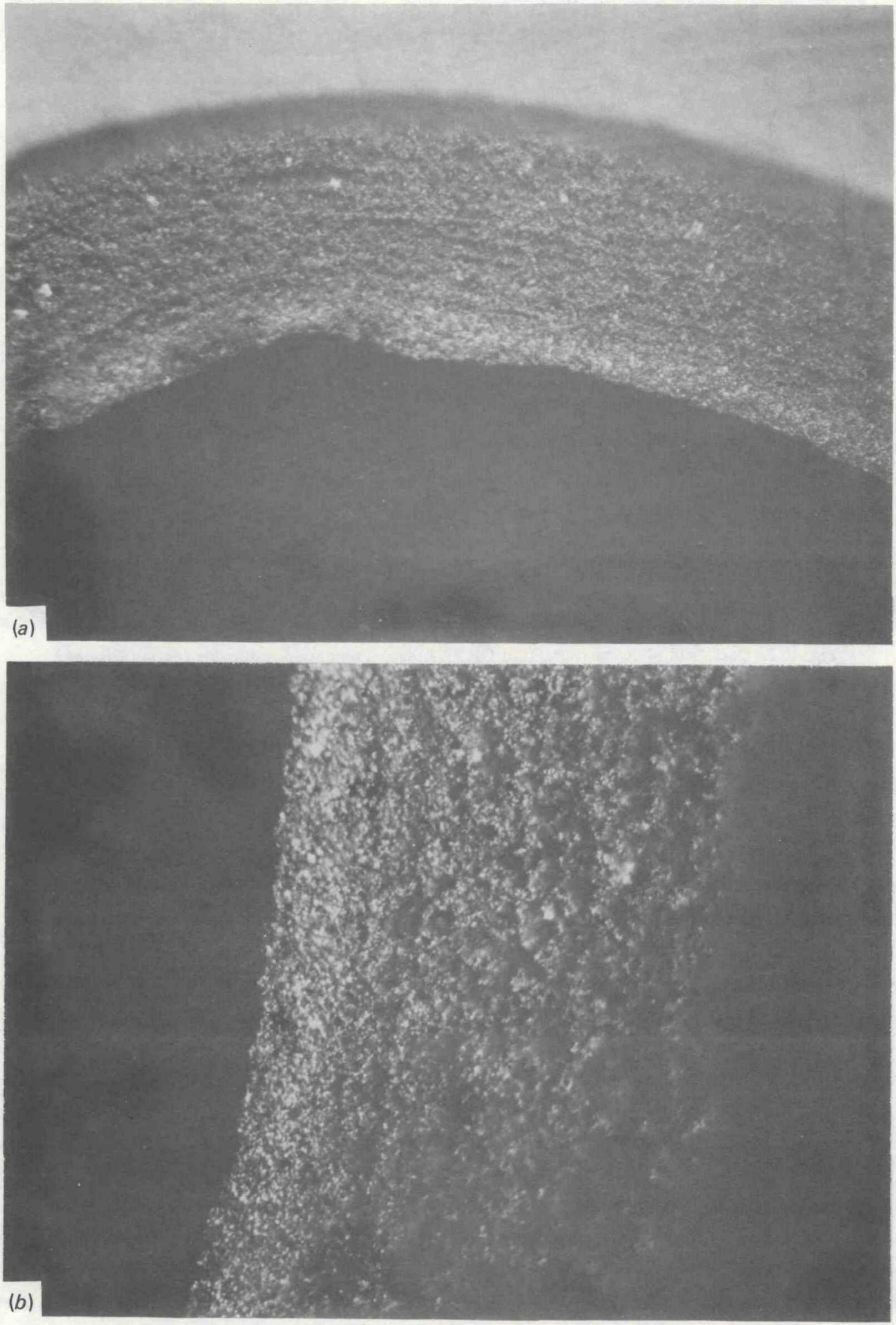

Fig. 10.1. Ceramographic section of particle charge OR-1849 HT plasma-oxidized. (a) 500:1; (b) 1000:1. 


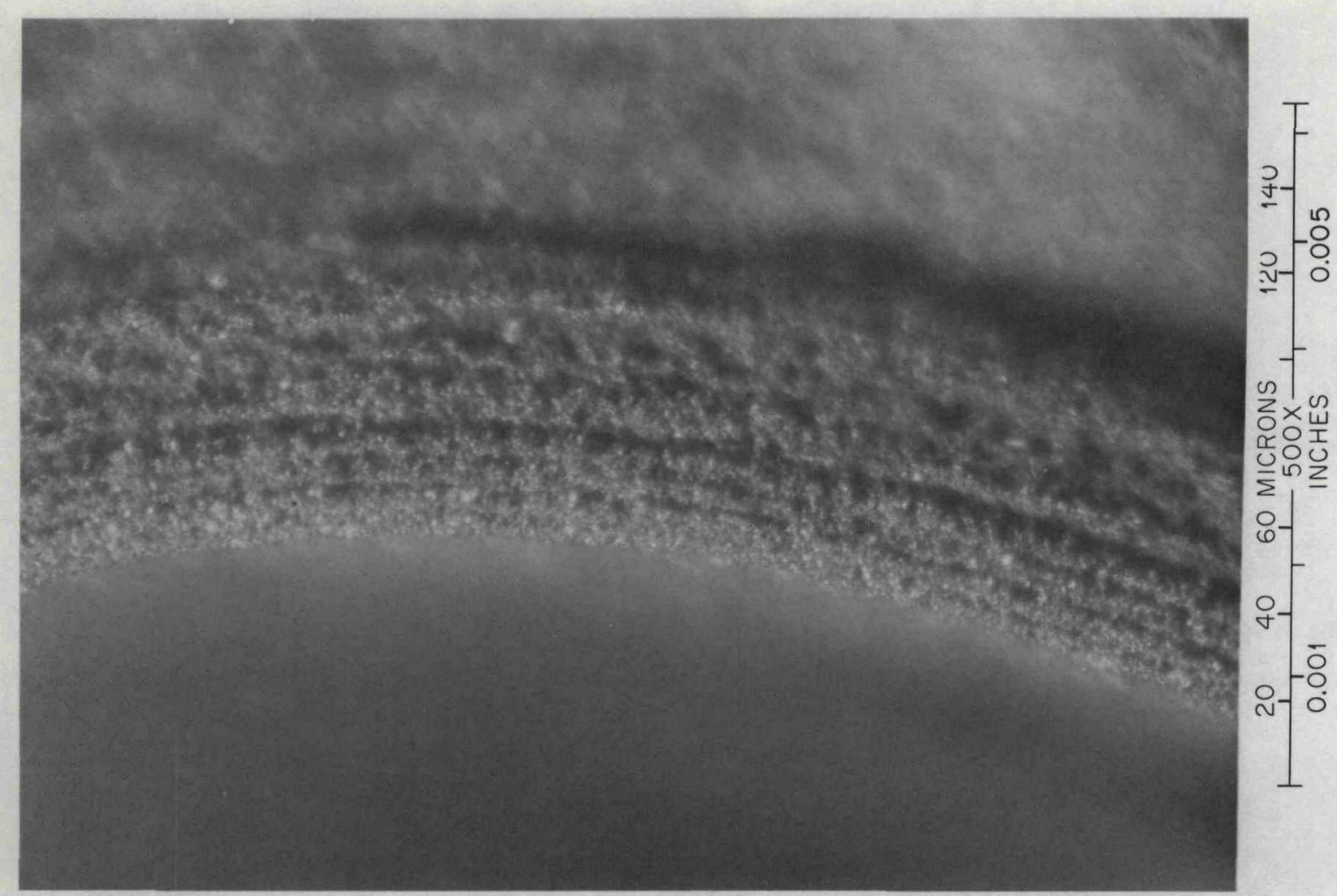

Fig. 10.2. Dark-field photomicrograph of ORNL's plasma oxidation results for coating OR-1849.

\subsection{Transmission Electron Microscopy}

ORNL coating OR-1849 was examined by TEM. ${ }^{4}$ Samples were prepared by hot pressing a mixture of LTI fragments and aluminum powder. A slice of this mount was ground to about 1 to 2 mils in thickness, then thinned by argon ion-milling until sufficiently thin for electron transmission. The specimen was observed in both the bright-and dark-field modes. For dark-field imaging the diffraction aperture was located on the $(002)$ reflection of the pyrocarbon structure; coherently diffracting regions within the growth features appeared in the image.

A close examination of TEM results on various ORNL coatings (including OR-1849) revealed that the LTI coatings contain two size ranges of structural features. Each range consists of spherical growth features which contain zones about their periphery in which pyrocarbon crystallites are present on a dimensional scale of about $1000 \AA$. These pyrocarbon crystallites are arranged with their $c$ axes approximately parallel with the radius of the growth feature. The core contains clusters of spherical objects with a diameter of about $100 \AA$, which are thought to be nuclei for the formation of the growth feature. The size of the growth features depends on the number of layers of crystallites around the periphery. In the large size range, the growth feature contains many layers of the peripheral pyrocarbon crystallites, whereas in the smaller size range, the growth features contain fewer peripheral crystallites and the primary constituent is the nucleus cluster. Regions where there is a high concentration of the smaller growth features are thought to be the ROC regions as determined by plasma oxidation. The most easily oxidizable carbon is thought to be the nuclei clusters. Those regions where there is a high concentration of the large-diameter growth features are the POC regions as determined by plasma oxidation. 


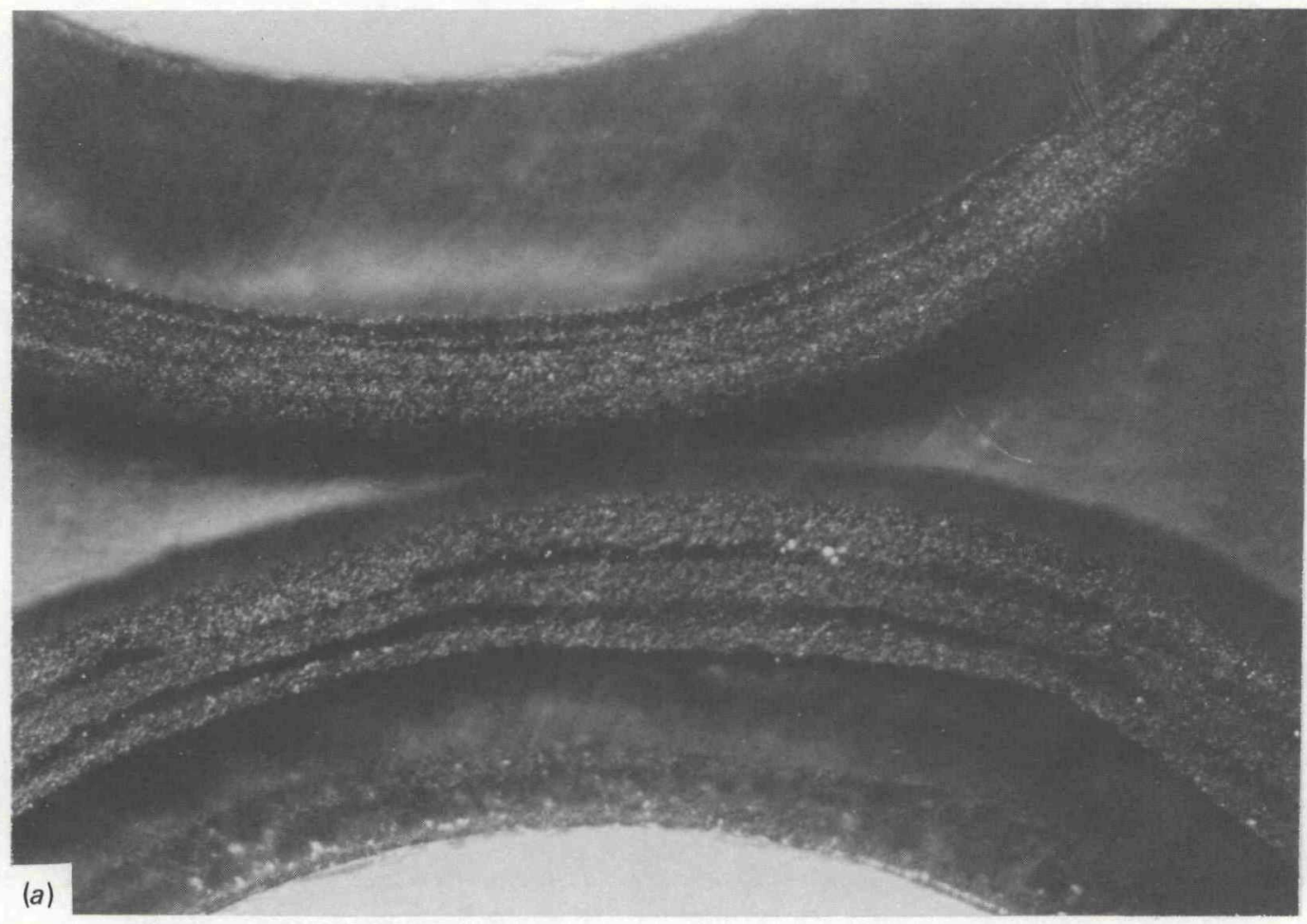

เ
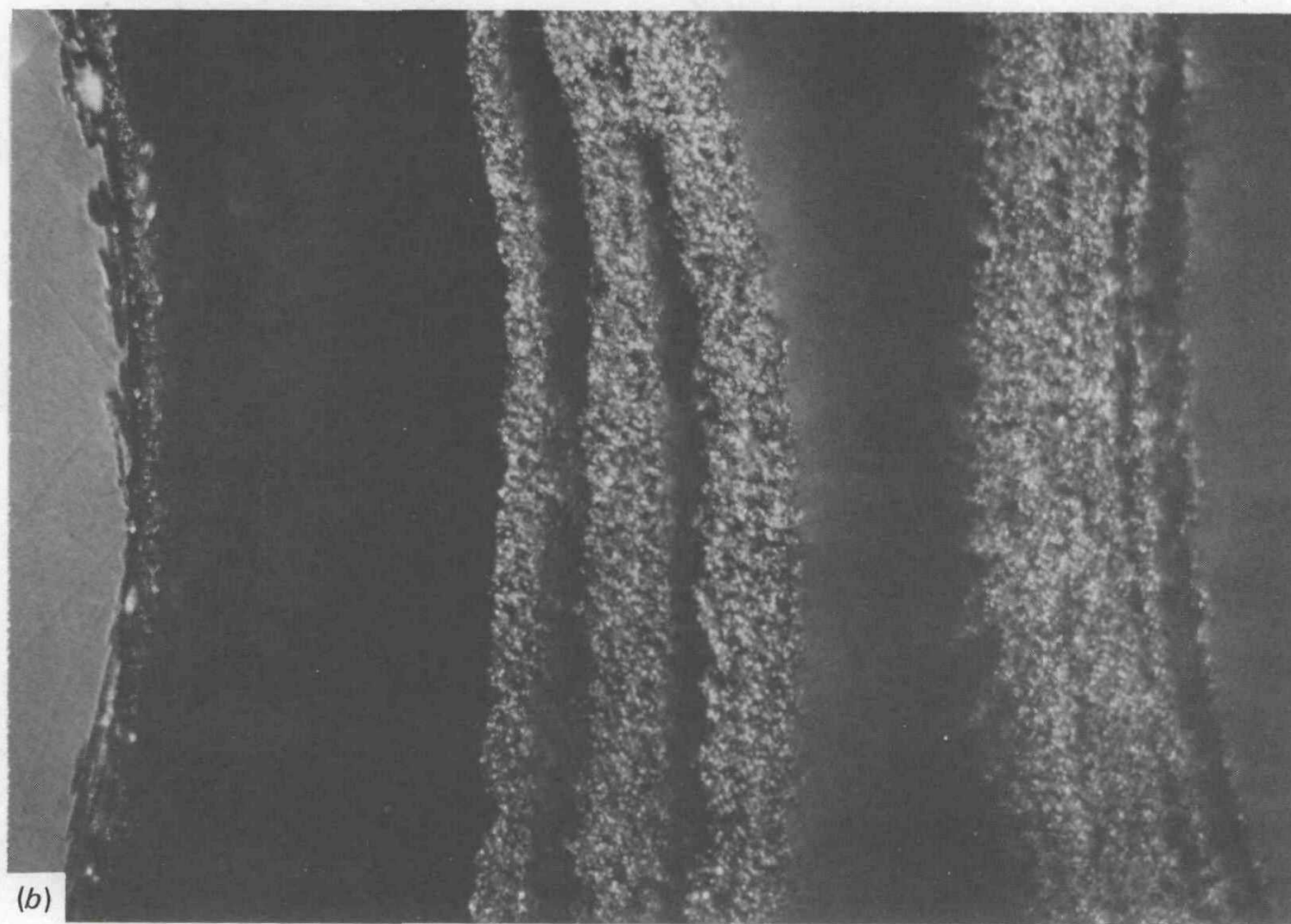

Fig. 10.3. Ceramographic section of particle charge OR-1749 HT plasma-oxidized. (a) 500:1; (b) 1000:1. 


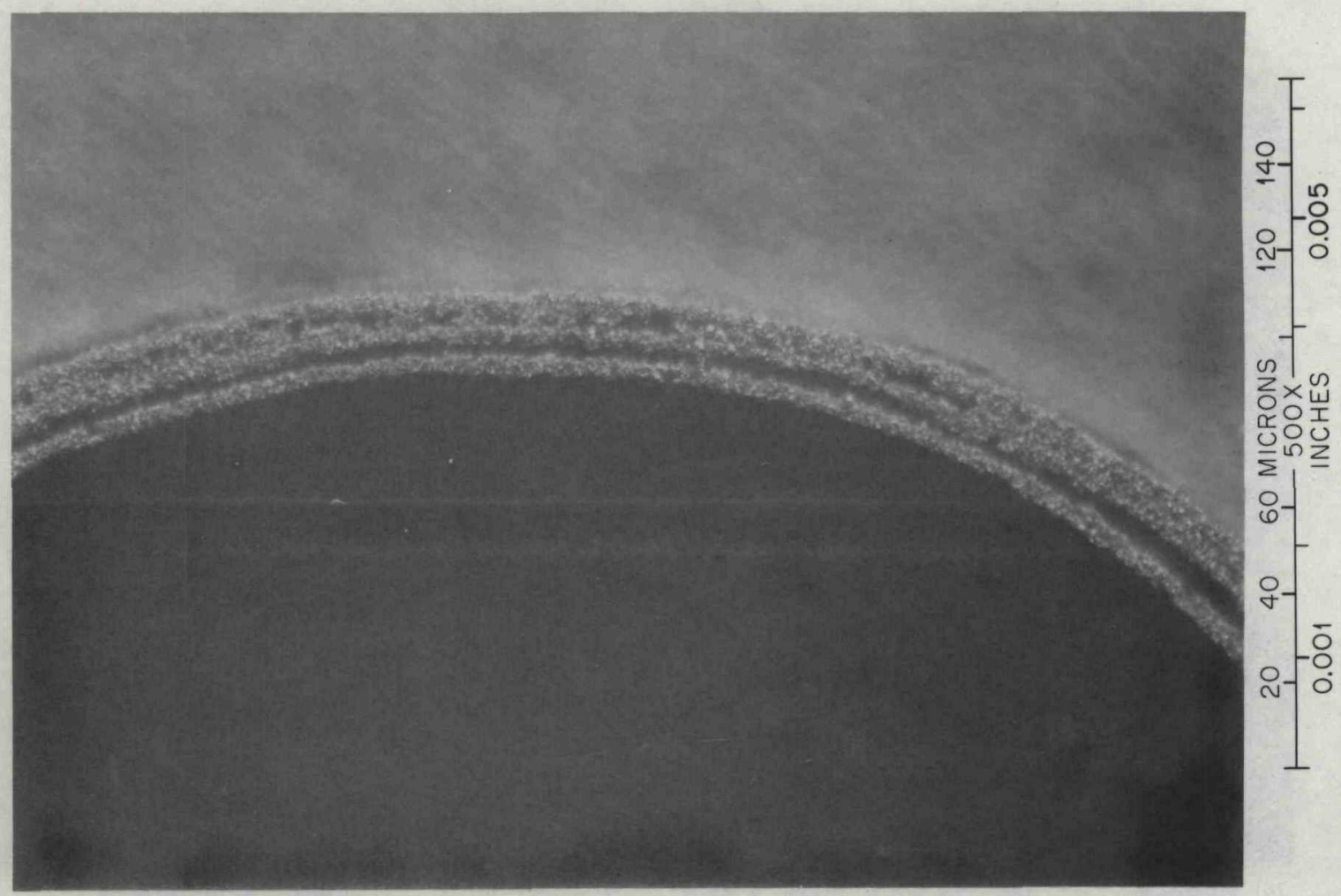

Fig. 10.4. Dark-field photomicrograph of ORNL's plasma oxidation results for coating OR-1749.
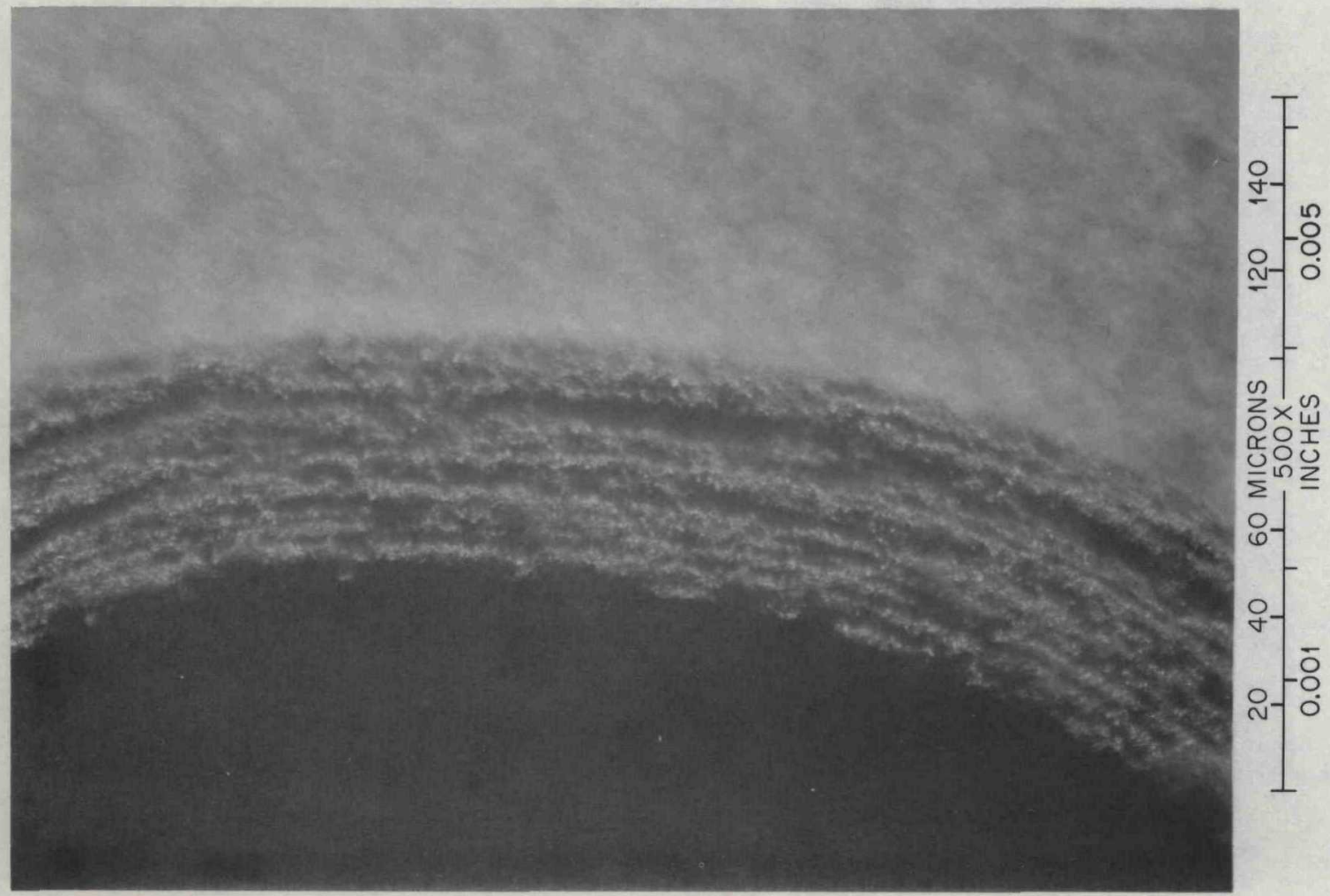

Fig. 10.5. Dark-field photomicrograph of ORNL's plasma oxidation results for coating OR-1838. 
Figure 10.6 is a transmission electron photomicrograph of coating OR-1849 in bright field, showing spherical or partially spherical growth features. Some growth feature boundaries are indicated at positions $A, B$, and $C$. Typical diameters for these growth features are on the order of $0.5 \mu \mathrm{m}$. Figure 10.7 is a similar photomicrograph but in dark field of the same area. The comparable feature boundaries are marked. The bright areas indicate regions containing coherently diffracting crystallites that correspond to the particular diffracted intensity used to form the image.

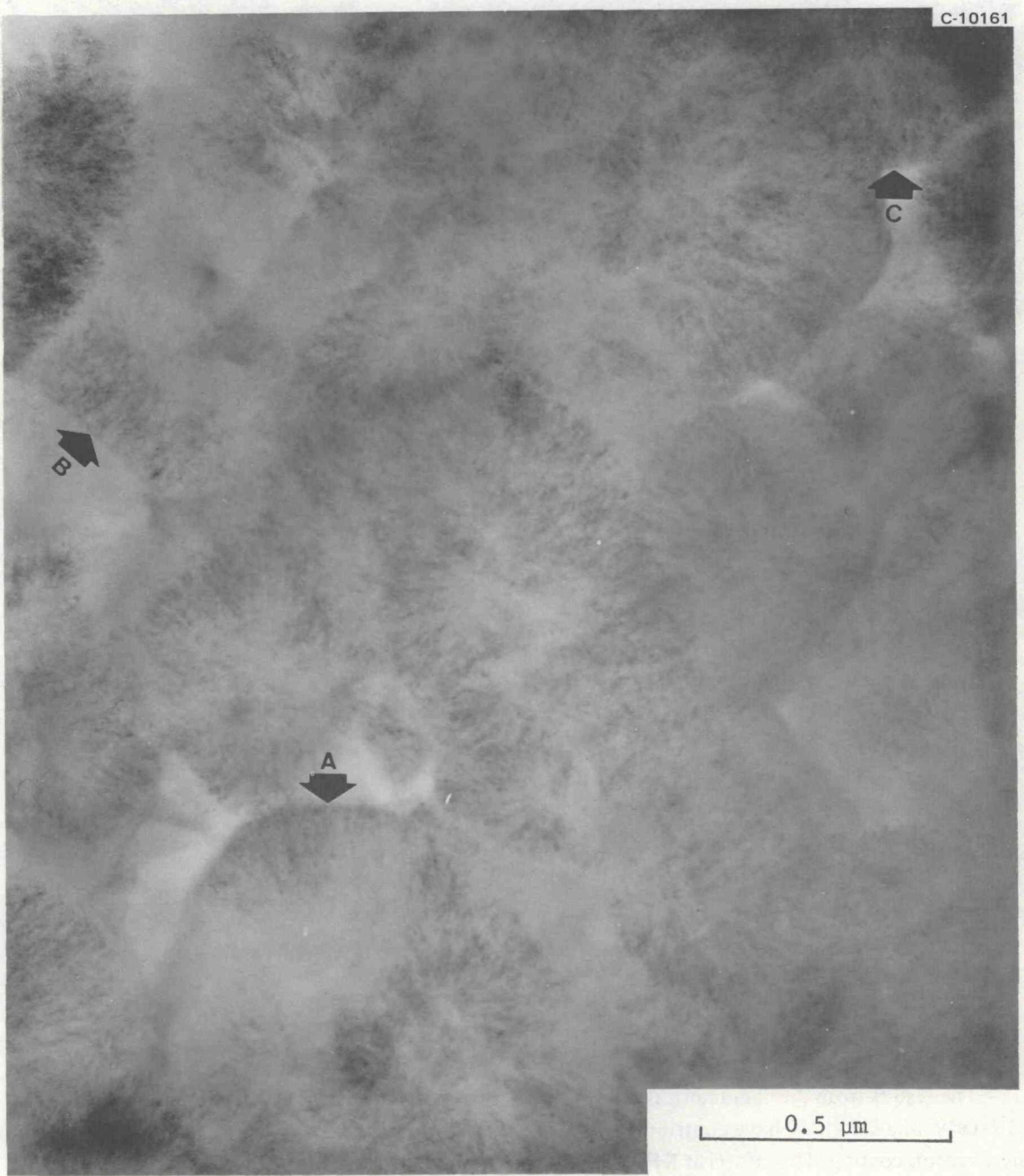

Fig. 10.6. Transmission electron photomicrograph of coating OR-1849 in bright field, showing spherical or partially spherical growth features at positions $A, B$, and $C$. 


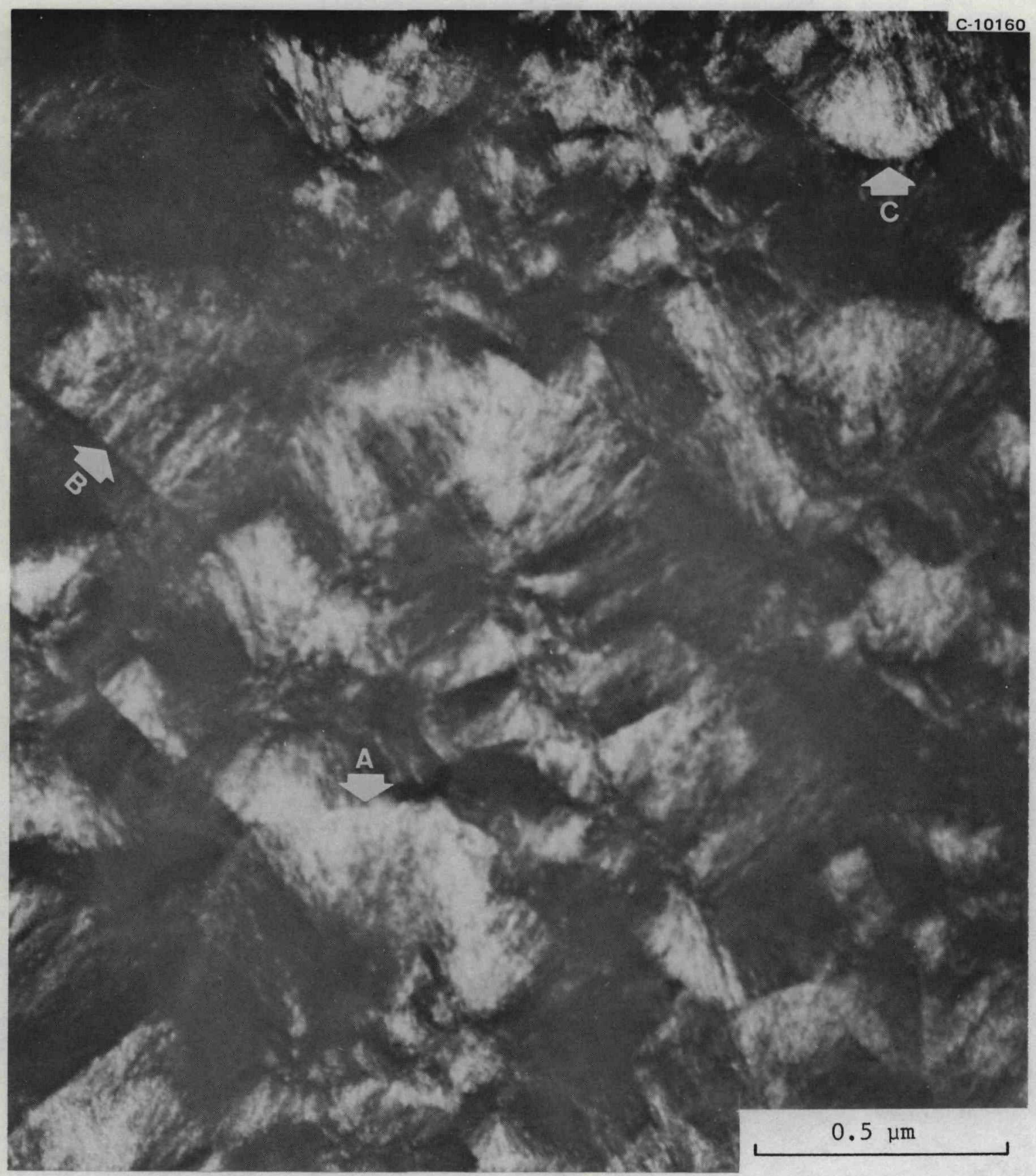

Fig. 10.7. Transmission electron photomicrograph of coating OR-1849 in dark field, showing spherical or partially spherical growth features at positions $A, B$, and $C$, corresponding to Fig. 10.6.

\subsection{Discussion}

The results from the characterization of the pyrocarbon LTI coatings on ORNL designs OR-1838, OR-1849, and OR-1749 have contributed to the overall effort of understanding the nature of the LTI pyrocarbon coating. The efforts at KFA-IRW, Jülich, and at ORNL have yielded results that are quite consistent. The OPTAF values for the three coatings listed above (as determined by the two laboratories) are essentially identical. The OPTAF values measured were in the range of 1.02 to 1.03 for each coating design. 
The plasma oxidation results for coating OR-1849, which contained a $75-\mu$-thick LTI, indicated that it contained a large quantity of ROC material. The distribution of this material was found to be homogenous, with the exception of the layer adjacent to the buffer layer. From the coatings investigated for this experiment, it agreed best with the survival criteria discussed earlier. Also, this coating showed good irradiation survivability as determined by visual PIE.

Plasma oxidation results for coating OR-1749, which had a nominal LTI design thickness of about $36 \mu$, indicated that this coating exhibited wide ROC bands running nearly continuously through the coating. The regions between these bands were made up almost entirely of POC material. This coating typically exhibited a relief structure of two or three bands of POC alternating with bands of ROC. In contrast to the survival criteria, the irradiation performance (per visual inspection) was much better than would have been anticipated.

Plasma oxidation of coating OR-1838, which had a nominal $64-\mu$-thick LTI, exhibited an etch structure of two or three zones of finely spaced bands of POC with alternate bands of ROC. This coating had good irradiation performance as determined by visual PIE.

The TEM results revealed that the pyrolytic LTI coatings (from various studies including OR-1849) are composed of two size ranges of growth features. The core of these spherical growth features contains clusters of spherical objects which are thought to be nuclei for the formation of the growth feature. Regions that contain a large concentration of the large growth features are thought to be the POC regions as determined by plasma oxidation. Regions with a high concentration of the smaller growth features are thought to be the ROC regions, with the nuclei clusters being the most easily oxidizable carbon.

\section{References}

1. Personal communication from H. Luhleich, KFA-IRW, Jülich, to V. J. Tennery, ORNL, May 1975.

2. J.P. Mathers, V. J. Tennery, and E. S. Bomar, Equipment Variables and Deposition Conditions Affecting the Plasma Oxidation of Pyrocarbon Coatings on HTGR Fuel Particles, ORNL/TM-5308 (June 1976).

3. R. L. Beatty et al., Irradiation Performance of HTGR Fertile Fuel in HFIR Target Capsules $H T-17, H T-18$, and $H T-19$ (in preparation).

4. C. S. Yust, V. J. Tennery, H. P. Krautwasser, and R. L. Beatty, Structual Characterization of HTGR Pyrocarbon Fuel Particle Coatings (in preparation). 


\section{CONCLUSIONS}

The results from irradiation of HFIR target capsules HT-12 through HT-15 and their subsequent postirradiation analyses have shown the following:

1. The LTI coatings, deposited using high LTI coating rates of approximately $20 \mu \mathrm{m} / \mathrm{min}$, which did not fail due to the pressure vessel failure mechanism, were batches OR-1838, OR-1840, and OR1849. Coated particles from batches OR-1840 and OR-1849 were further examined by hot chlorine leaching and gas-pressure methods. These tests indicated that some of the coated particles developed permeability during irradiation, in particular, particles irradiated at a temperature $\cong 1250^{\circ} \mathrm{C}$ and with burnups of $\geqslant 8 \%$ FIMA. In contrast, particles from the same batches showed no permeability at an irradiation temperature $\cong 1550^{\circ} \mathrm{C}$ and at burnups $\cong 16 \%$ FIMA. The nature of the permeability could not be determined by scanning electron micrographs. If further evidence shows that irradiation-induced permeability is a serious problem, then the design of coatings should be directed toward those resistant to both pressure vessel failure and irradiation-induced permeability.

2. The method of failure determination by visual inspection is not sufficient to determine the integrity of coated particles. To detect permeability in irradiated coatings, visual inspection must be followed by a more thorough inspection of the apparent intact coated particle. Both hot chlorine leach and fission gas measurements gave nearly equivalent indication of failed or intact particles. It is recommended that future failure determinations on Biso coatings be made by the hot chlorine leaching process or by the irradiated microsphere gamma analyzer, in addition to the PIE visual inspection.

3. Particle sample holders operated between 50 and $200^{\circ} \mathrm{C}$ higher than original design temperatures, depending on holder location in a particular graphite magazine. The holder temperatures by themselves were not adequate in describing particle operating temperatures. Maximum particle surface temperatures exceeded sample holder temperatures by as much as $100^{\circ} \mathrm{C}$ after one HFIR cycle and peaked at approximately $300^{\circ} \mathrm{C}$ higher during the fourth cycle in the high-temperature regions and in the sixth cycle in the low-temperature regions. In general, the particle operating temperatures in the low-temperature regions were 1200 to $1300^{\circ} \mathrm{C}$; in the high-temperature regions they were 1500 to $1600^{\circ} \mathrm{C}$.

4. The extremes in temperature and fast neutron fluence had a pronounced effect on the performance of the Poco graphite sample holders and magazines. The sample holders experienced severe swelling, in excess of $9.5 \%$, and distortion in capsule HT-15. The swelling of the graphite magazines in HT-15 completely closed the gap between the magazines and the aluminum containment. To avoid possible interference between fuel performance and graphite performance, it is recommended that future loose coated-particle capsules be limited to fluences about one and one-half HTGR design (approximately six HFIR cycles).

5. The percentage of the theoretical amount of krypton + xenon released into the void space of the intact $\mathrm{ThO}_{2}$ particles appeared to be primarily dependent on burnup and reached $\sim 90 \%$ at design burnup. The present results agreed with those determined by Janvier et al. ${ }^{1}$ for 80 to $90 \%$ dense $\mathrm{UO}_{2}$ kernels irradiated to 2 to $8 \%$ FIMA at 1000 to $1400^{\circ} \mathrm{C}$.

6. Oxygen release per fission $(\mathrm{O} / f)$ is a function of temperature and burnup and can be expressed by Eq. (7.1) for $\mathrm{ThO}_{2}$ particles irradiated in the target region and stored out-of-reactor for approximately two years. Oxygen release is apparently significantly affected by the interaction of sesquioxides of yttrium and rare-earth elements with uranium to form $\mathrm{UO}_{2+x}$. Calculated in-HFIR $\mathrm{O} / f$ values at 5\% FIMA are smaller than the measured amounts because of the presence of significant concentrations of the 27-day $\mathrm{PaO}_{2+x}$. Calculated in-HTGR O $/ f$ values at 5\% FIMA are larger than those measured in the present experiments because the in-HTGR concentrations of $\mathrm{UO}_{2+x}$ are about half of those in the present HT particles. 
7. The coated particles showed complete retention of fission products ${ }^{106} \mathrm{Ru}$ and ${ }^{144} \mathrm{Ce}$ to burnups of $16 \%$ FIMA and at irradiation temperatures of $15500^{\circ} \mathrm{C}$. Fission products ${ }^{137} \mathrm{Cs}$ and ${ }^{125} \mathrm{Sb}$ were lost under these same conditions. No ${ }^{110} \mathrm{Ag}$ was detected in the particles examined. Cesium loss ranged from 0 to $40 \%$ in coated particles for burnups of 6 to $16 \%$ FIMA with coatings impermeable to hot chlorine leach, and up to approximately $65 \%$ in particles with defective coatings at the higher temperatures. At the lower temperatures the cesium loss was $<1 \%$ at burnups of $<8 \%$ FIMA.

\section{References}

1. J. C. Janvier, M. Bruet, and R. Blanchard, "Fission Gas Pressure Evolution in Irradiated Coated Particles," Proc. Conf. on the HTGR, London, 1973, British Nuclear Energy Society, preprint No. 34. 


\section{ACKNOWLEDGMENTS}

The authors wish to acknowledge the efforts of many people who made significant contributions in the planning, execution, and evaluations of these irradiation capsules. We would like to acknowledge W. P. Eatherly for his help in planning these capsules and in coordinating the particle design and fabrication of components to meet irradiation schedules; J. L. Scott for coating design calculations; C. B. Pollock, formerly with the Metals and Ceramics Division and now with the Materials Engineering Development Department, Y-12, and C. Hamby, Jr., for fabricating and characterizing the fertile particles; J. H. Coobs and D. E. Rosson for the capsule disassembly and visual inspection of the irradiated particles and graphite components; E. S. Bomar, Jr., V. J. Tennery, and C. S. Y ust for the characterization of the pyrocarbon coatings; R. S. Crouse and T. J. Henson for the scanning electron micrographs, R. L. Beatty, F. J. Homan, and E. L. Long, Jr., for the many helpful discussions. The capsule operation and irradiation history were provided by B. H. Montgomery, and fission rates in the target facility were provided by H.T. Kerr of the Engineering Technology Division. The gamma spectroscopy measurements were performed by F.F. Dyer and L. L. Fairchild of the Analytical Chemistry Division and Chemical Technology Division respectively. The hot chlorine leach measurements and associated analyses were performed by W. R. Rogers and H. Parker of the Analytical Chemistry Division. The postirradiation anneals and preparation of particles were performed by R. L. Towns of the Chemical Technology Division. The authors also acknowledge the assistance of the Technical Publications Department, Information Division, in the preparation of this report. 


\section{APPENDIX A}

Operating Temperature Histories for Loose-Coated

Particles Irradiated in HT-12 through HT-15 


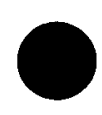

$\bullet$ 

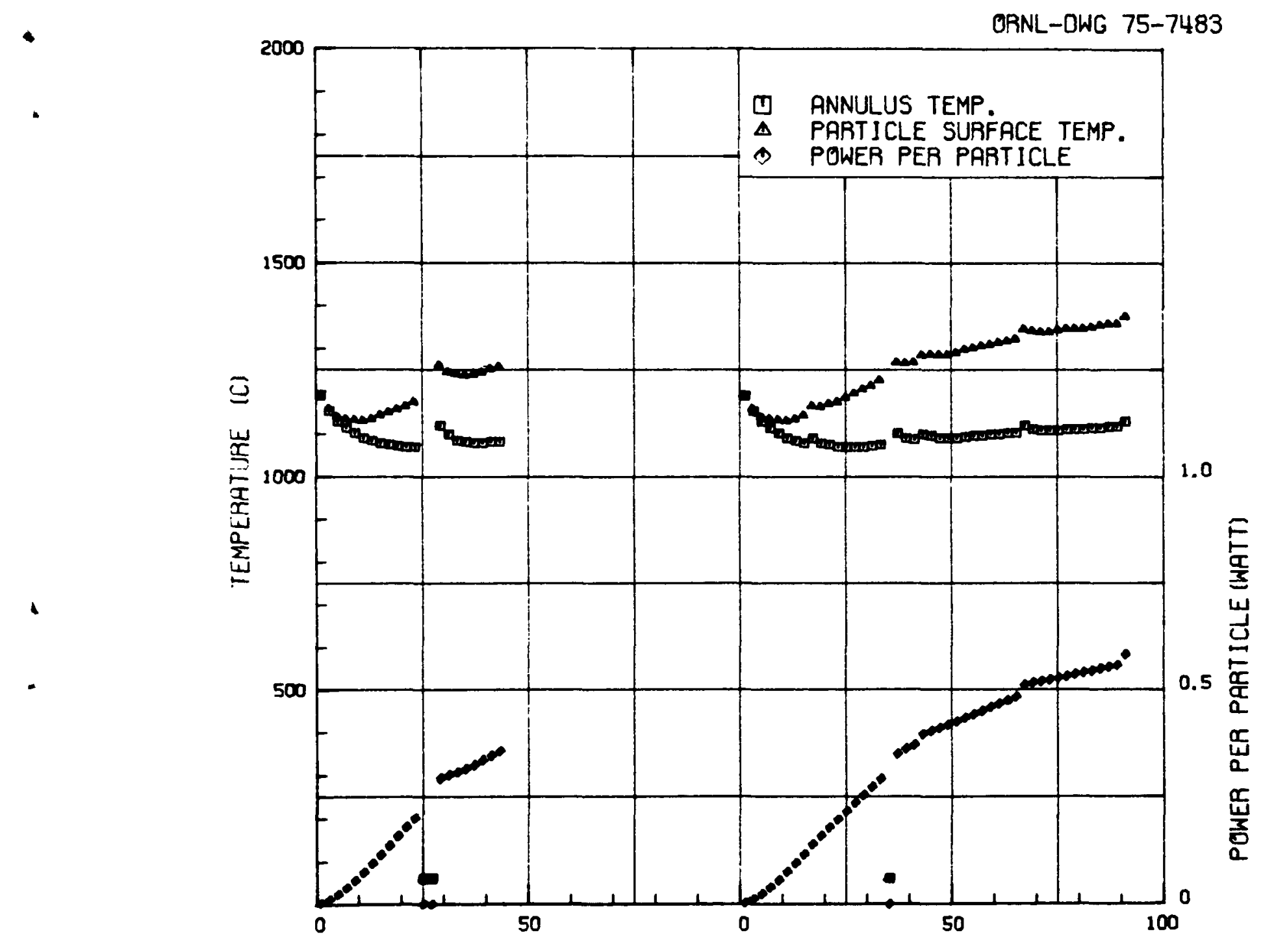

TIME FROM BEGINNING OF IRRADIATION (DAYS)

HT-12\&13 PART ICLE HOLDER 2 BATCH GA-4252-08 815.0 MICRON PART ICLE DIAMETER 


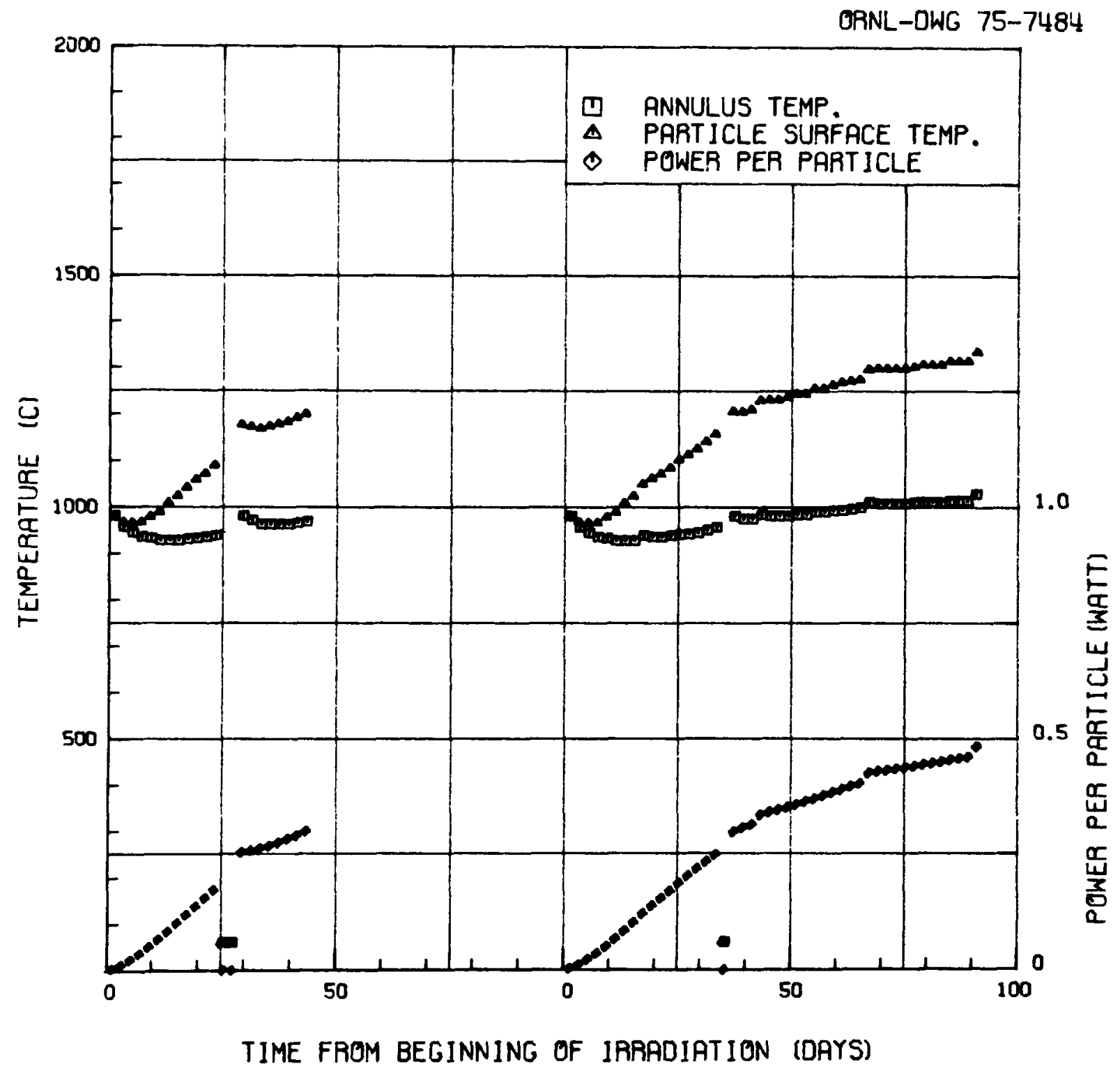

HT-12\&13 PARTICLE HOLDER 4 BATCH OR-1850 694. O MICRON PARTICLE DIAMETER 


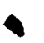

$\cdot$

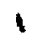

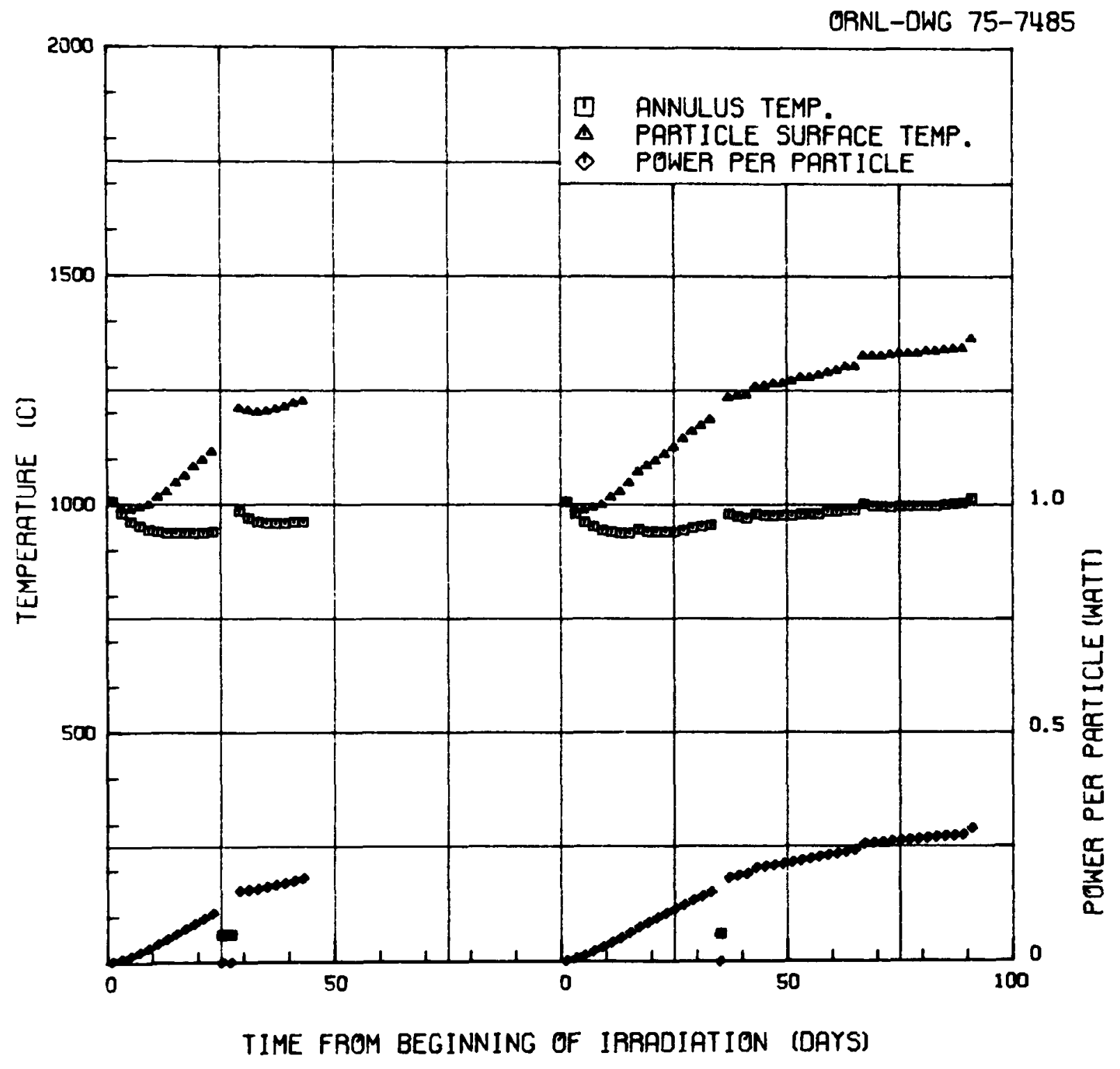

HT-12\&13 PARTICLE HOLDER 5 BATCH OR-1846 482. 0 MICRON PARTICLE DIAMETER 


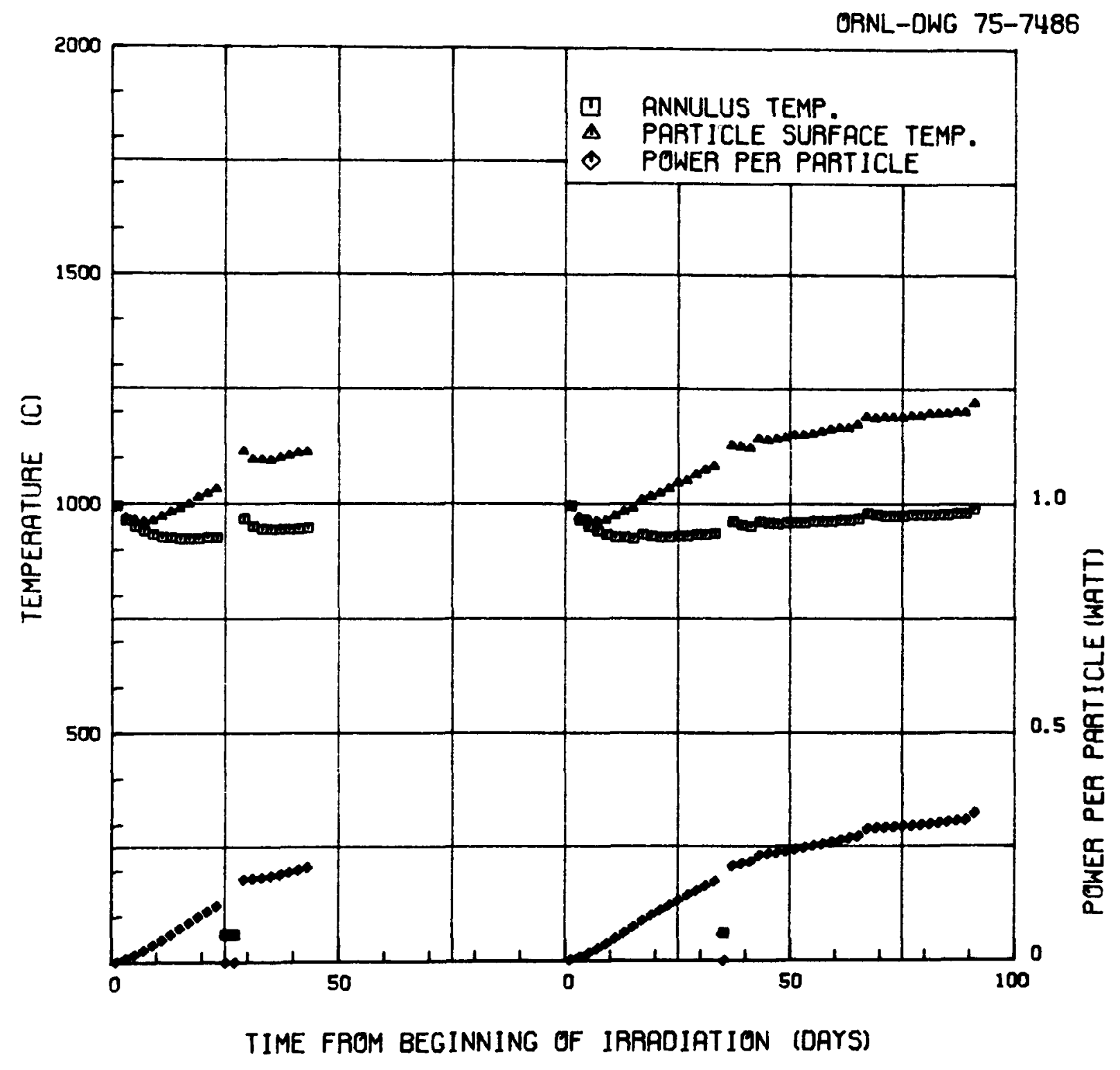

HT-12\&13 PART ICLE HOLDER 7 BATCH GA-4252-00 

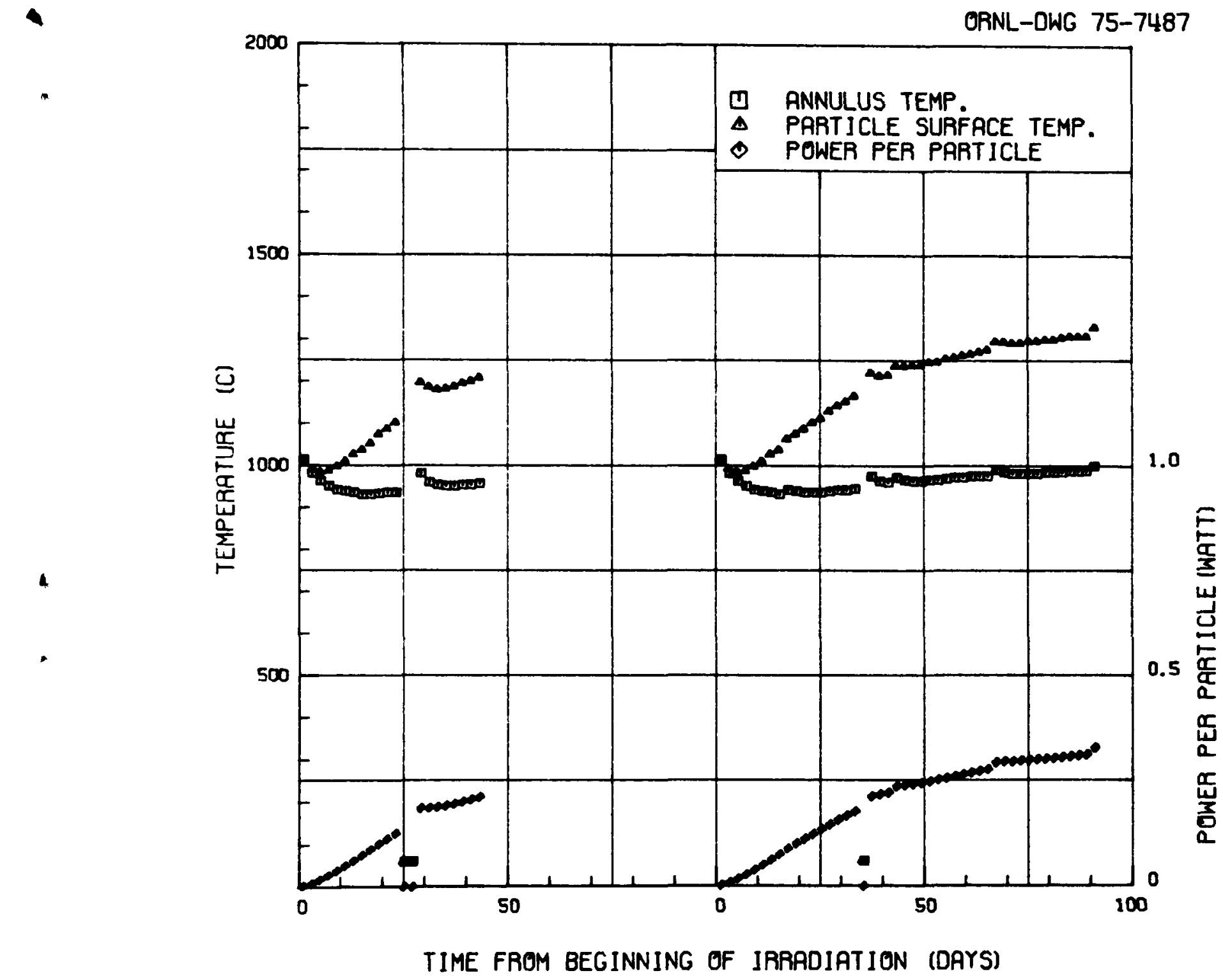

$$
\begin{gathered}
\text { HT-12\&13 PART ICLE HOLDER } 8 \text { BATCH OR-1840 } \\
552.0 \text { MICRON PARTICLE DIAMETER }
\end{gathered}
$$




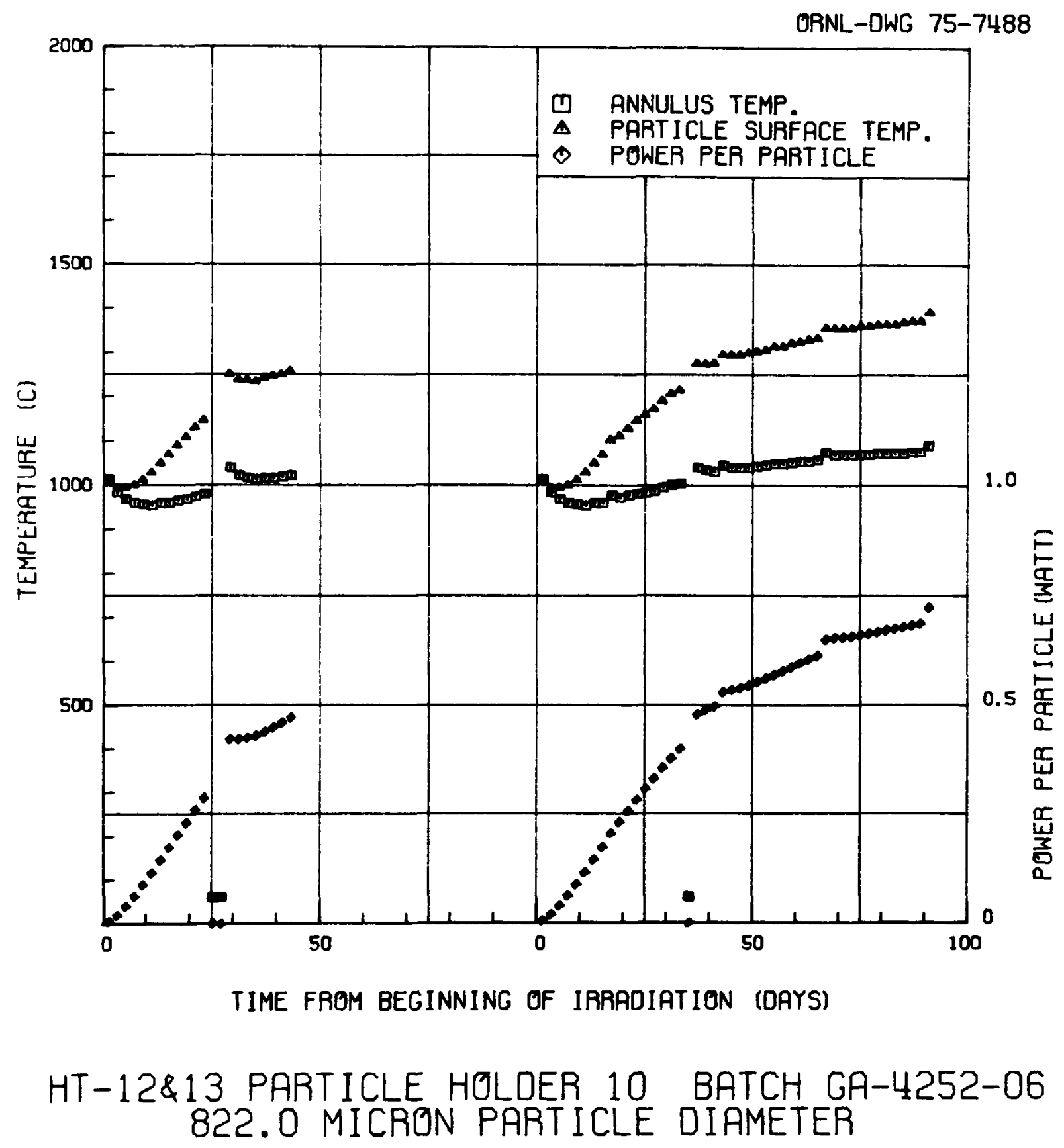




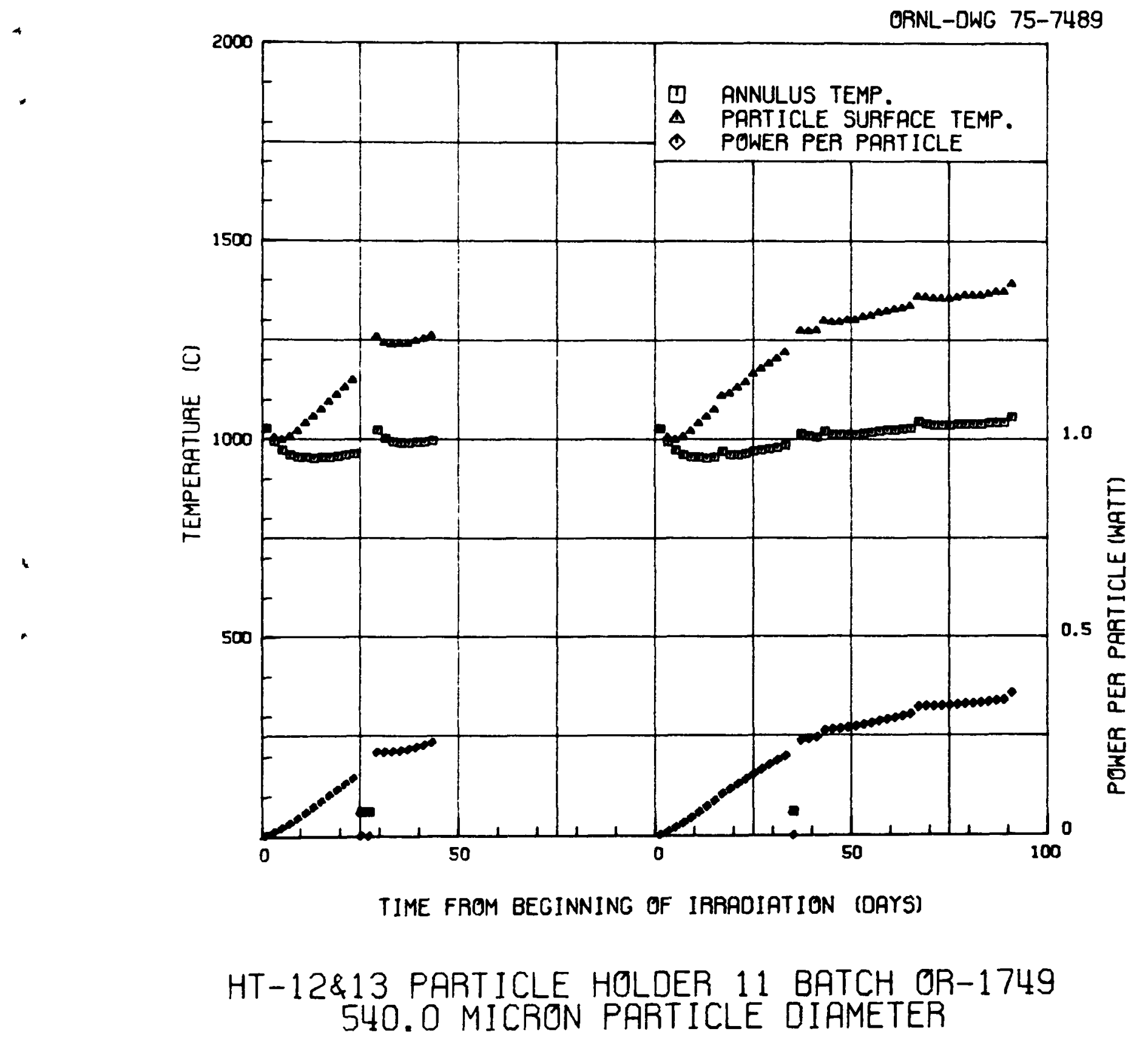


ORNL-DWG 75-7490

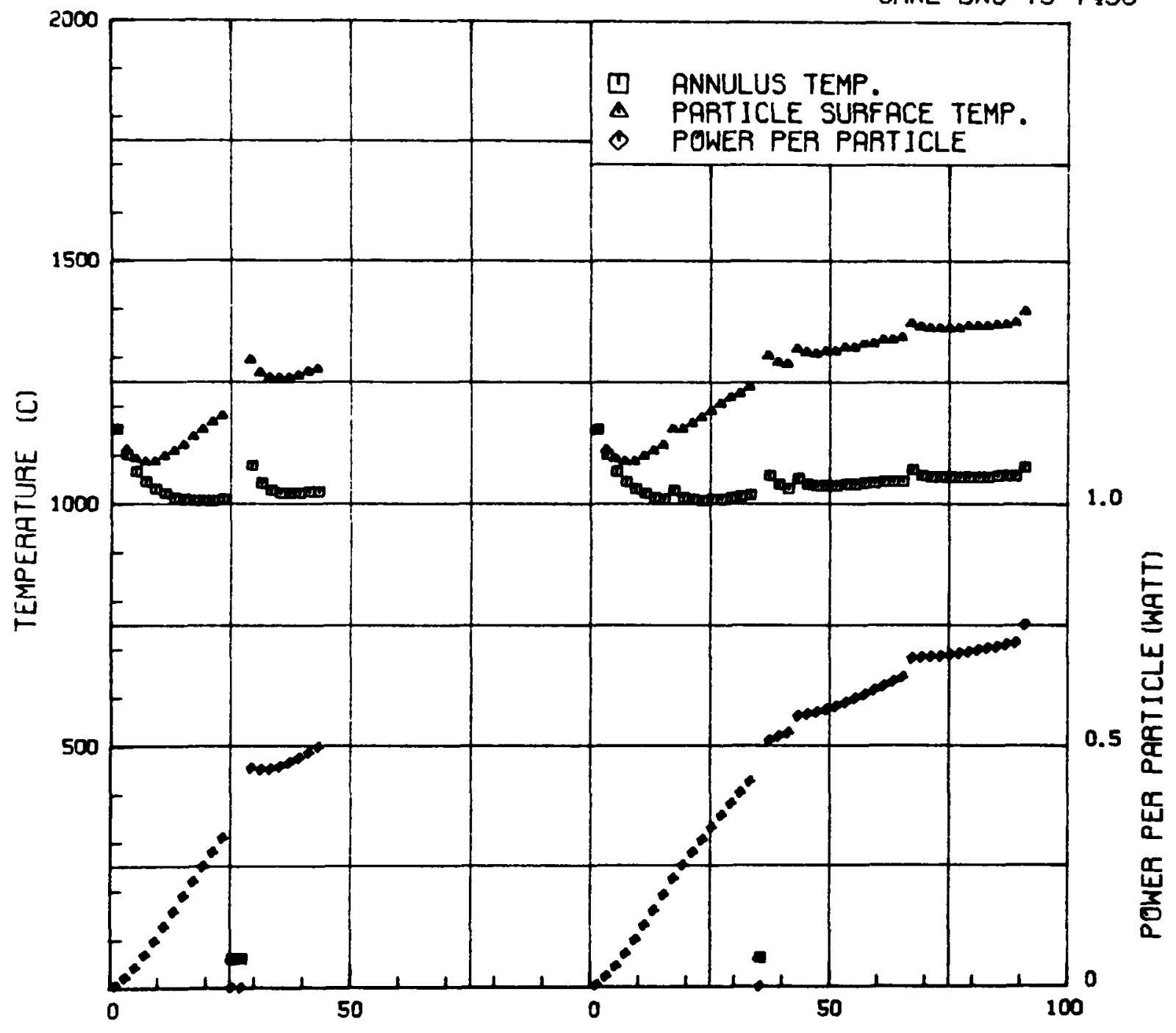

TIME FROM BEGINNING OF IRRADIATION (DAYS)

HT-12\&13 PARTICLE HOLDER 13 BATCH OR-1849 815.0 MICRON PART ICLE DIAMETER 
$a$

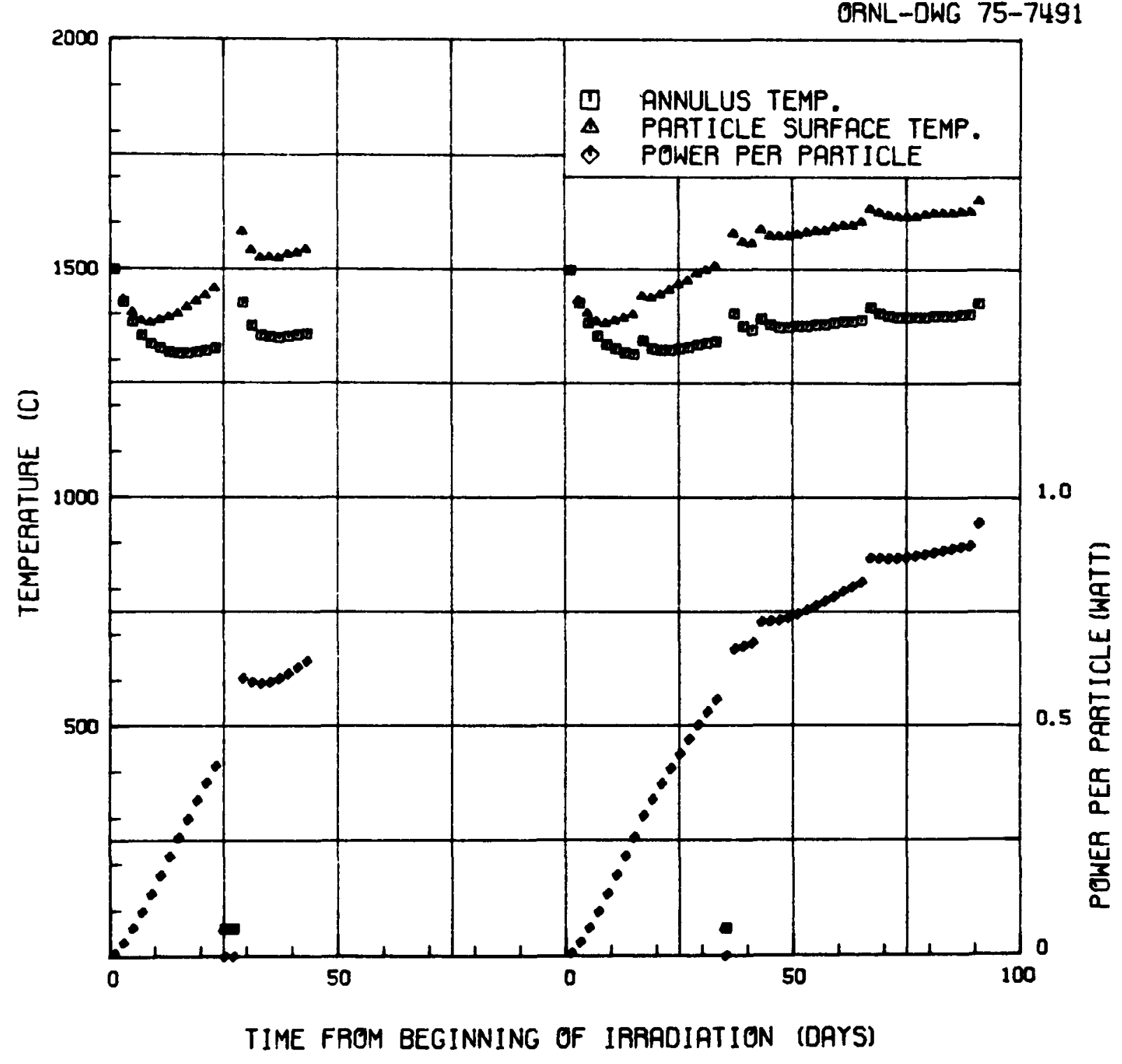

HT-12\&13 FARTICLE HOLDER 15 BATCH GA-4252-08 815.0 MICRON PART ICLE DIAMETER 
ORNL-OWG 75-7492

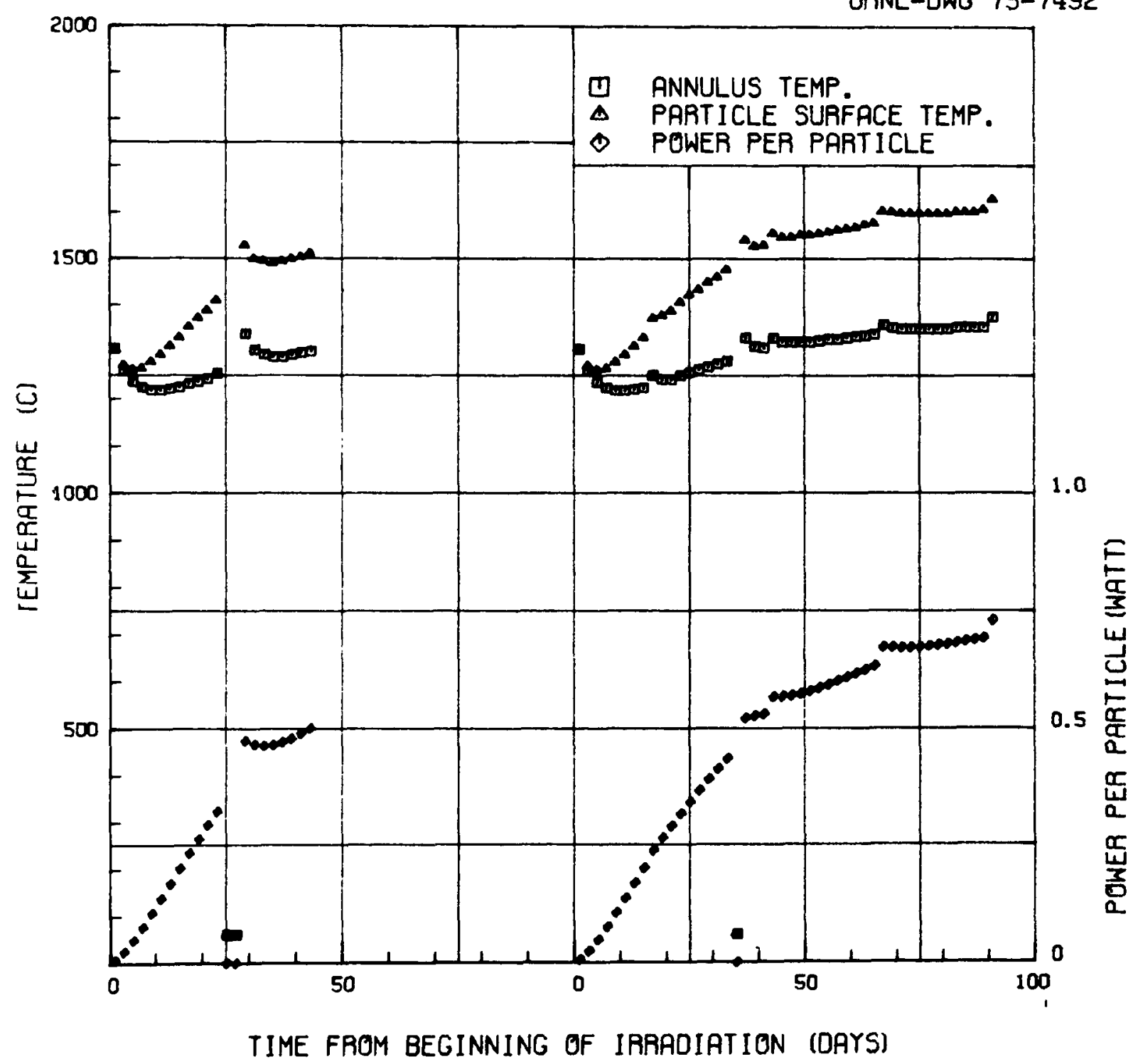

HT-12\&13 PART ICLE HOLDER 17 BATCH OR-1850 694. O MICRON PARTICLE DIAMETER 


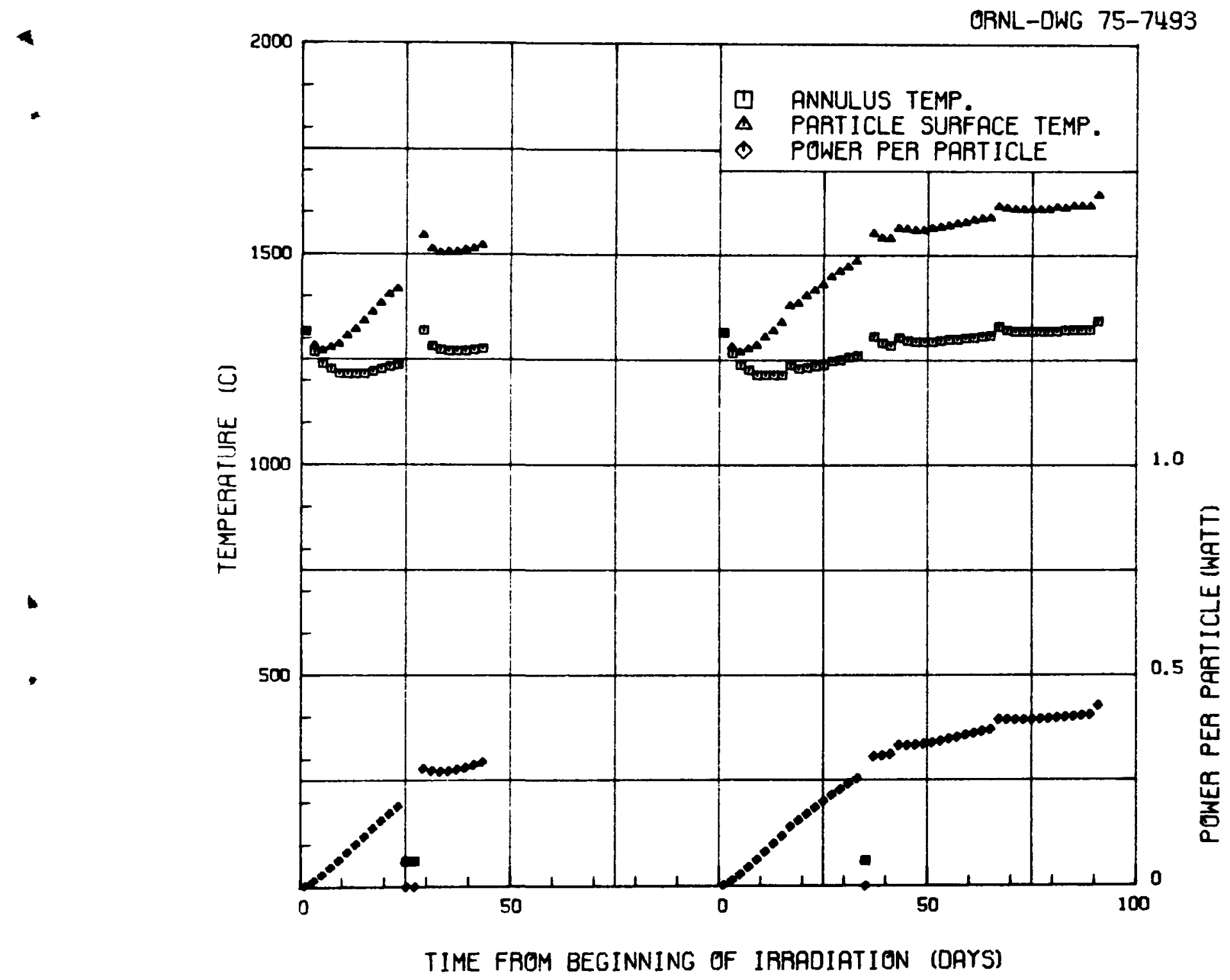

HT-12\&13 PARTICLE HOLDER 18 BATCH OR-1846
482.0 MICRON PART ICLE DIAMETER 


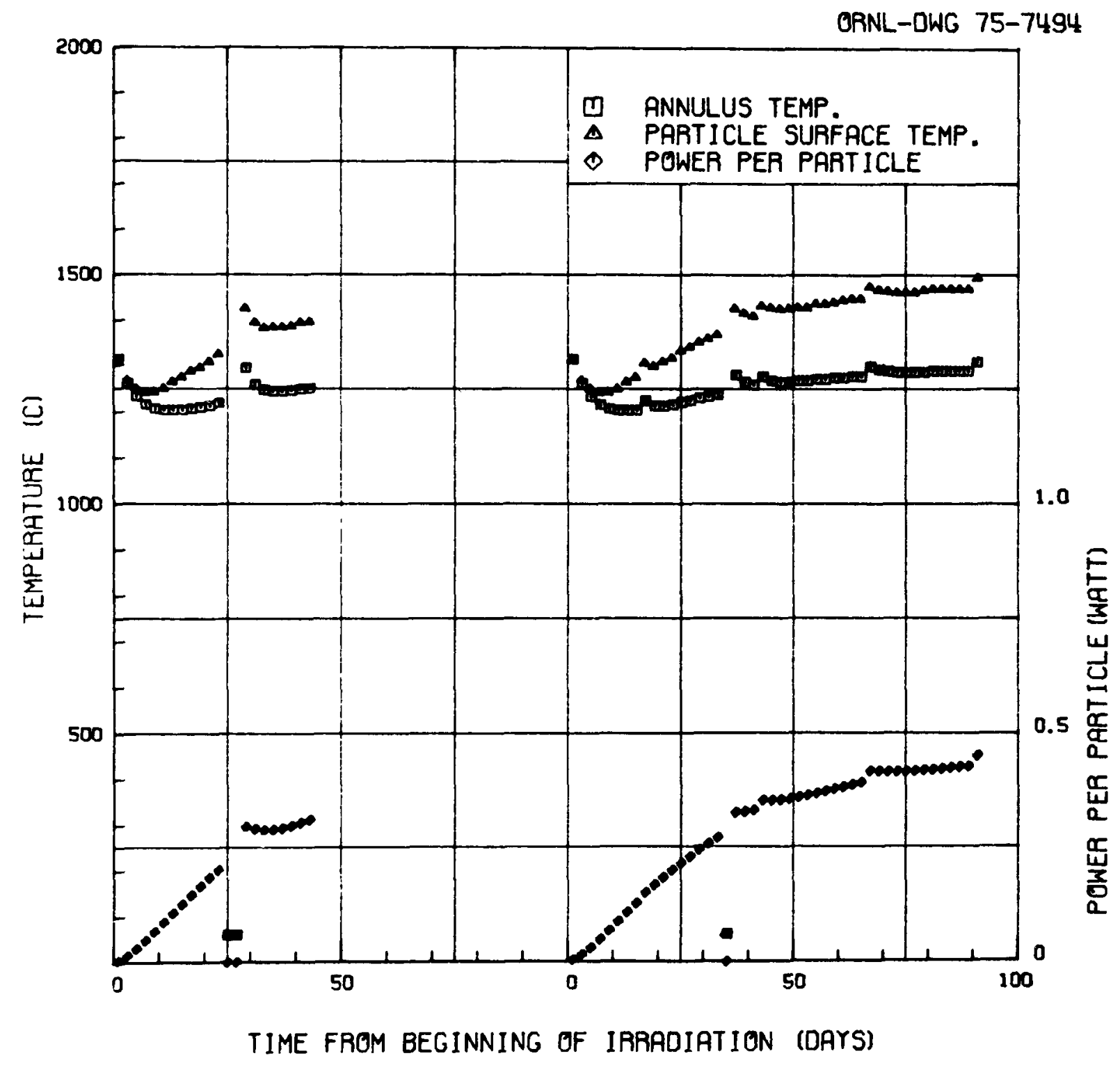

HT-12\&13 PARTICLE HOLDER 20 BATCH GA-4252-00 719.0 MICRON PARTICLE DIAMETER 


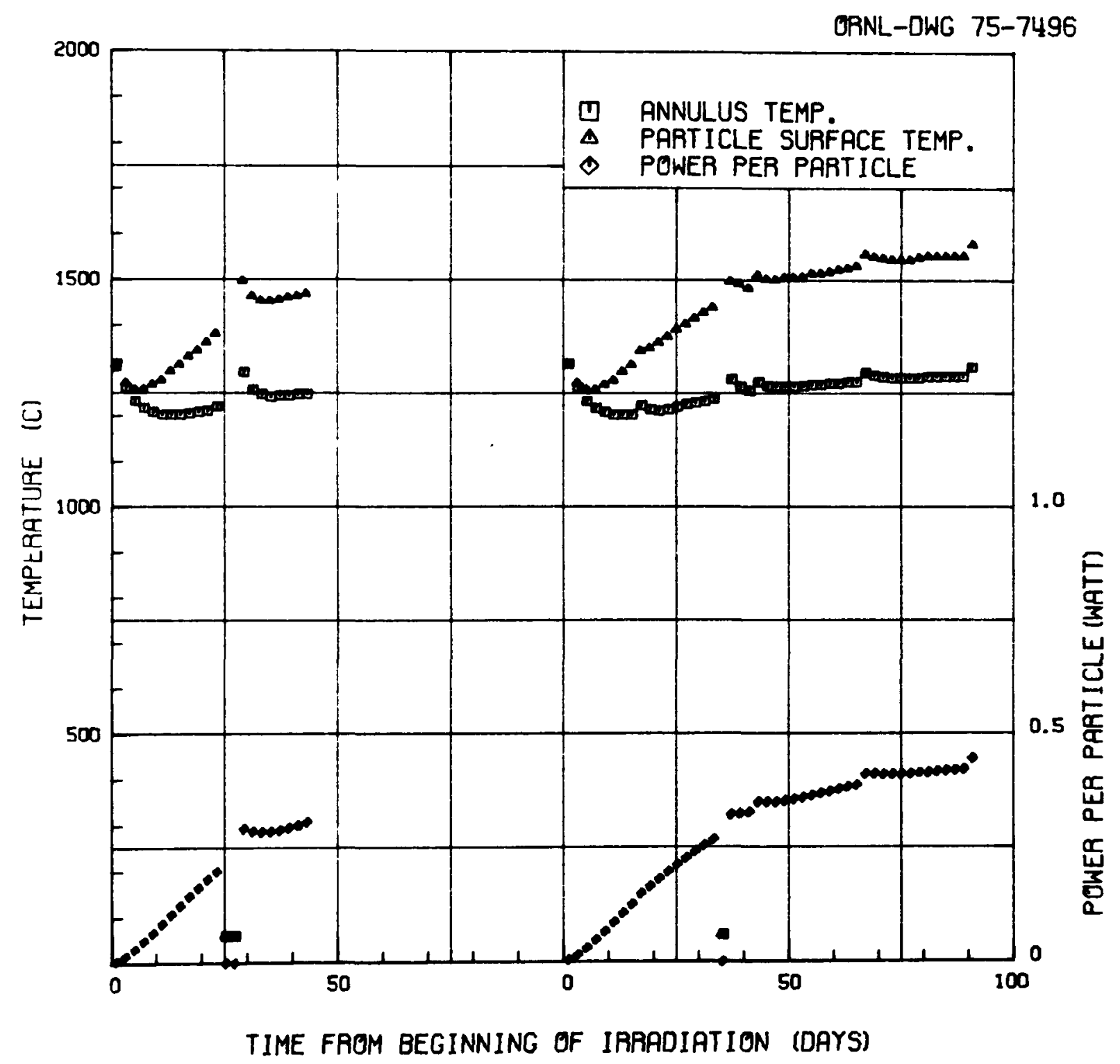

HT-12\&13 PARTICLE HOLDER 21 BATCH OR-1840 552. O MICRON PARTICLE DIAMETER 


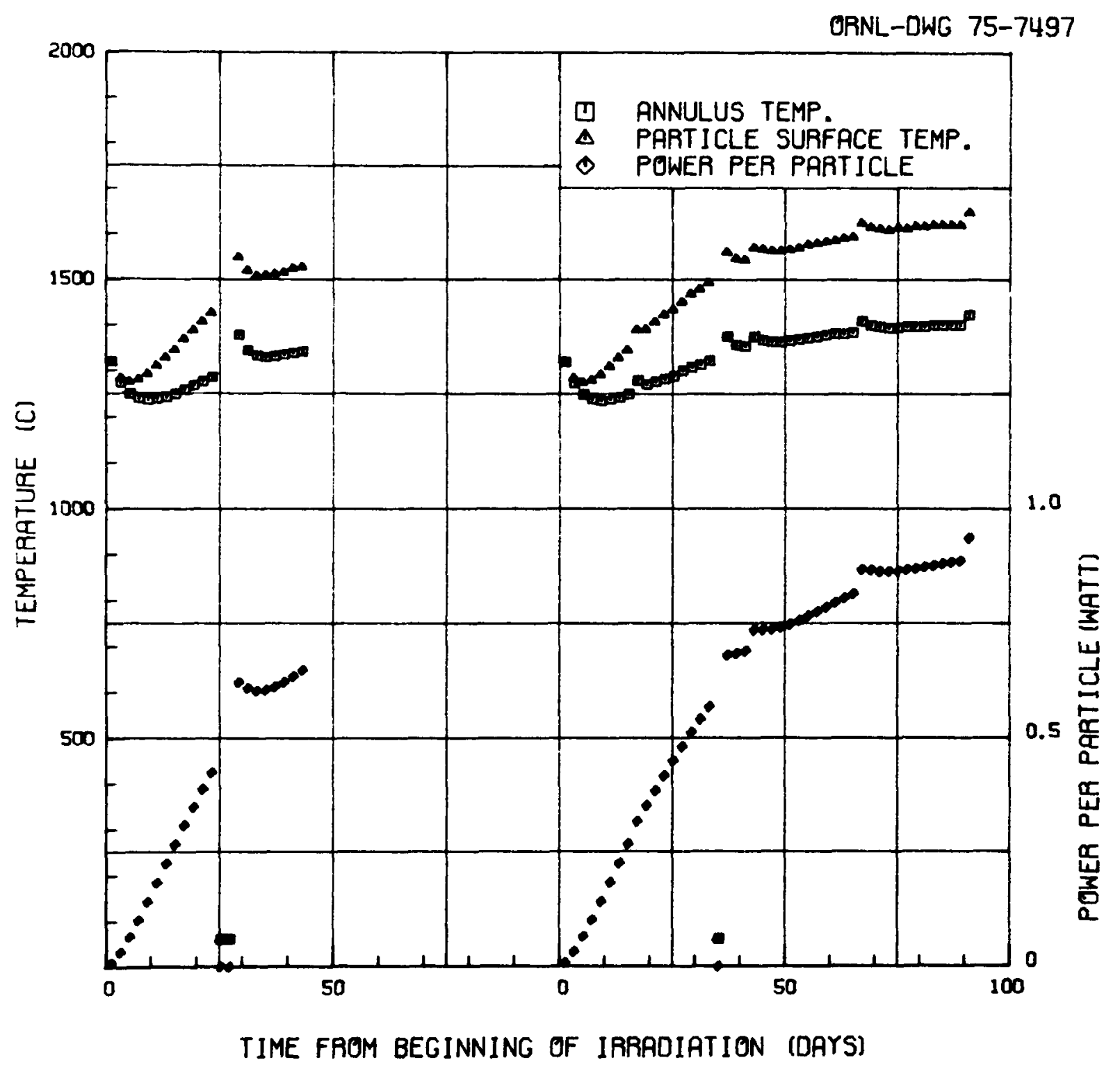

HT-12\&13 PARTICLE HOLDER 23 BATCH GA-4252-06 822.0 MICRON PART ICLE DIAMETER 


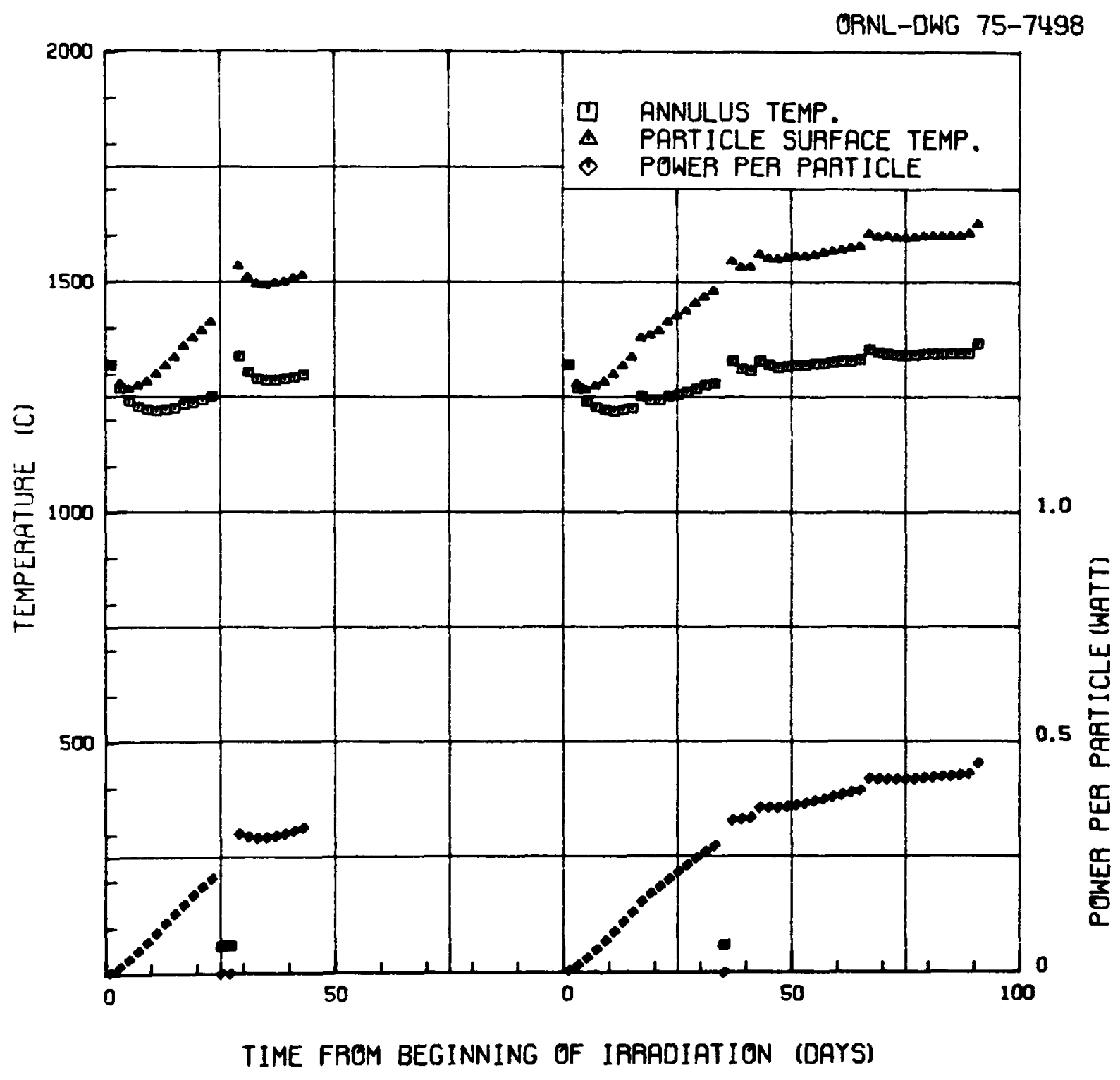

HT-12\&13 PARTICLE HOLDER 24 BATCH OR-1749 540.0 MICRON PARTICLE DIAMETER 


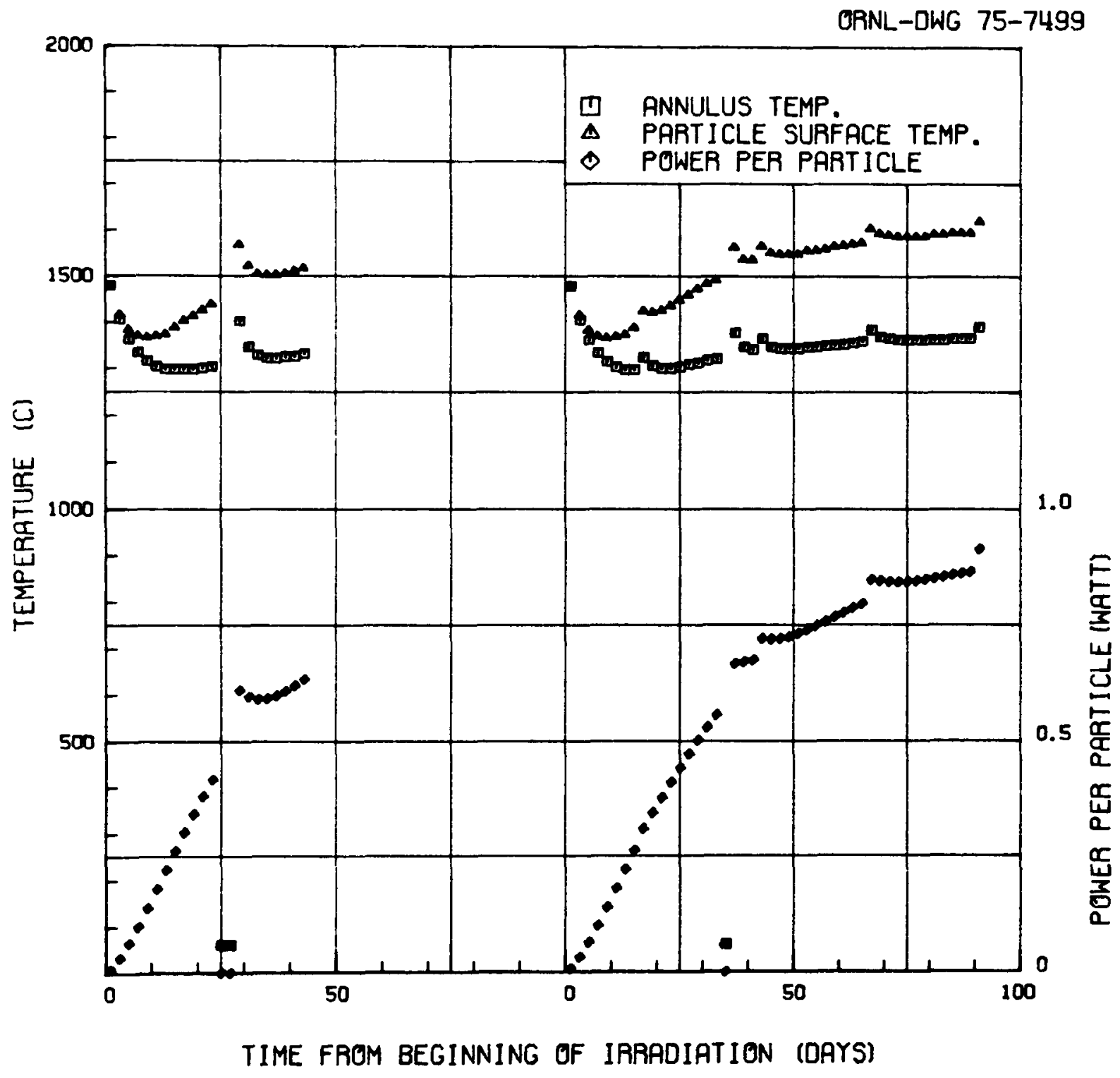

HT-12\&13 PARTICLE HOLDER 26 BATCH OR-1849 816.0 MICRON PARTICLE DIAMETER 


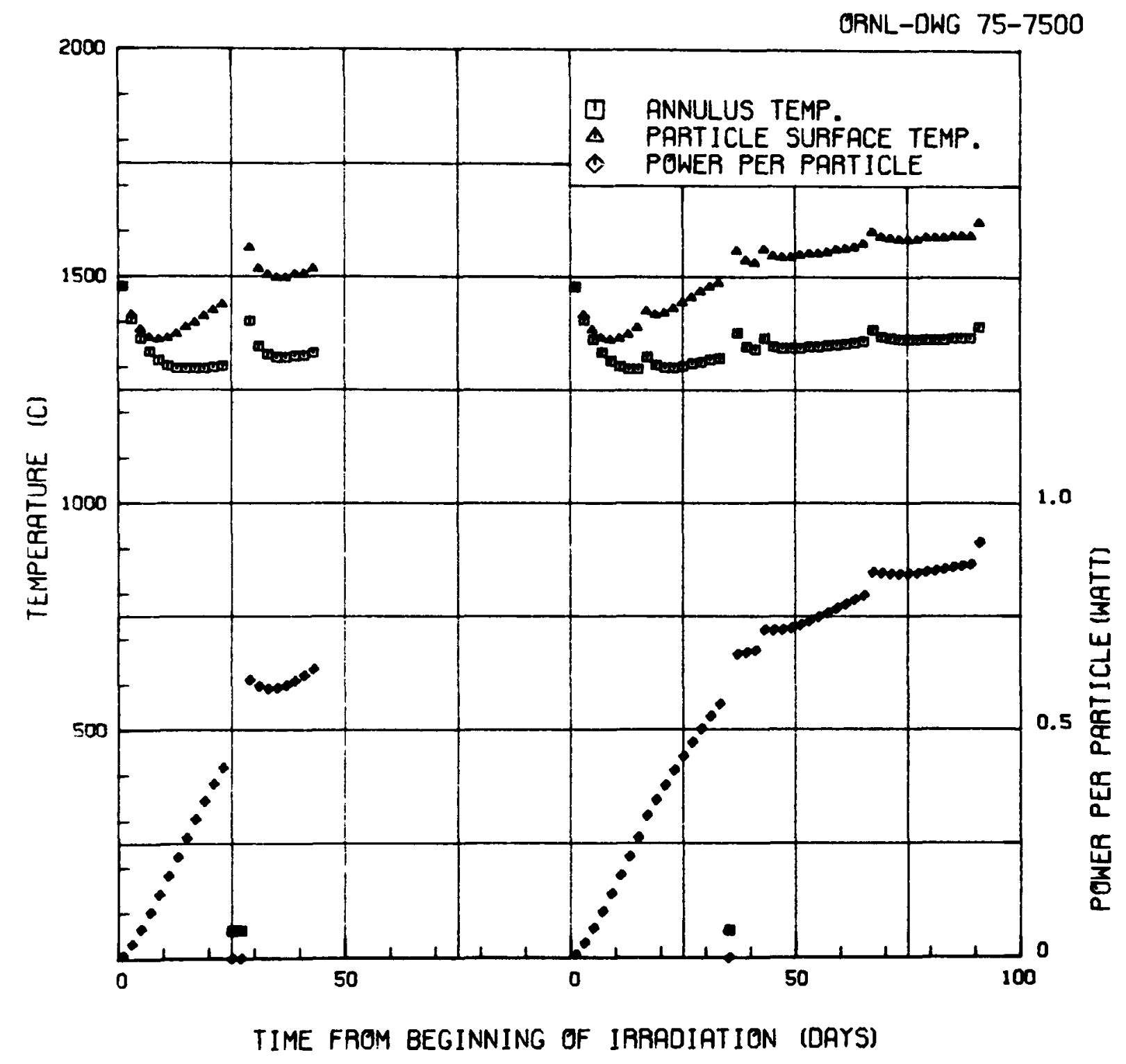
HT-12\&13 PARTICLE HOLDER 27 BATCH GA-4252-02 824. 0 MICRON PARTICLE DIAMETER


ORNL-DWG 75-7501

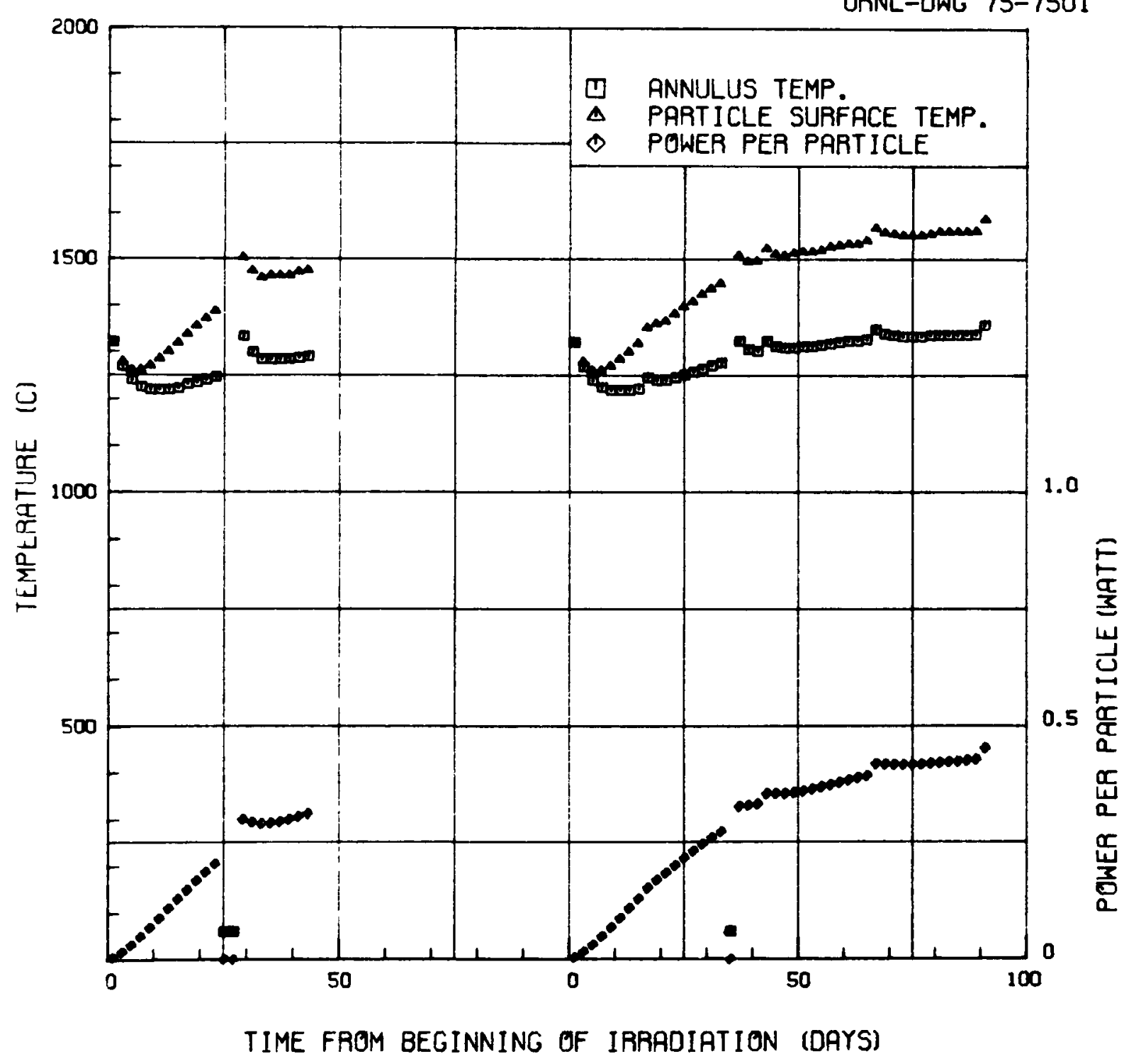

HT-12\&13 PARTICLE HOLDER 29 BATCH OR-1838 594.0 MICRON PARTICLE DIAMETER 


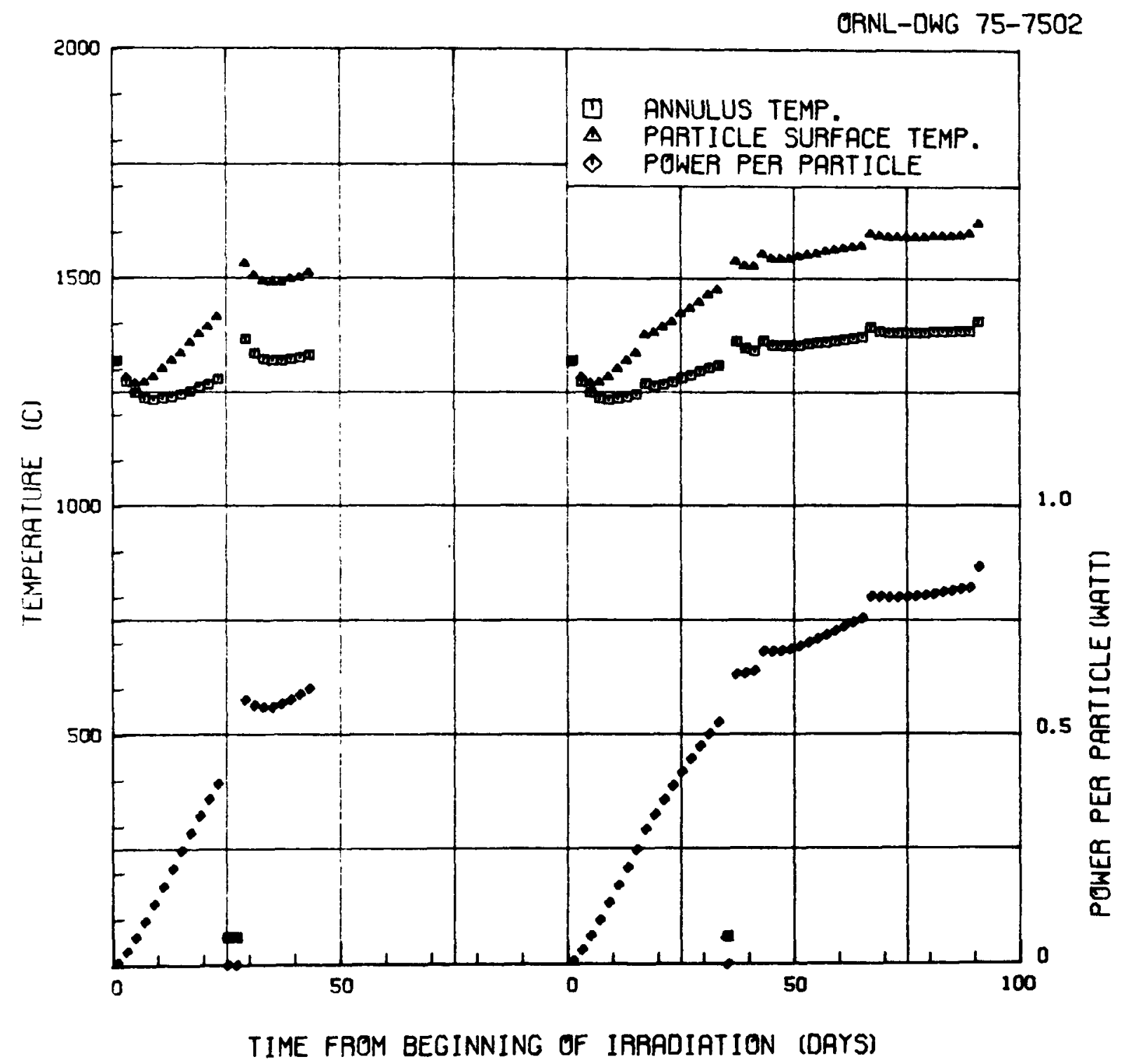

HT-12\&13 PARTICLE HOLDER 30 BATCH GA-4252-03 819.0 MICRON PARTICLE DIAMETER 


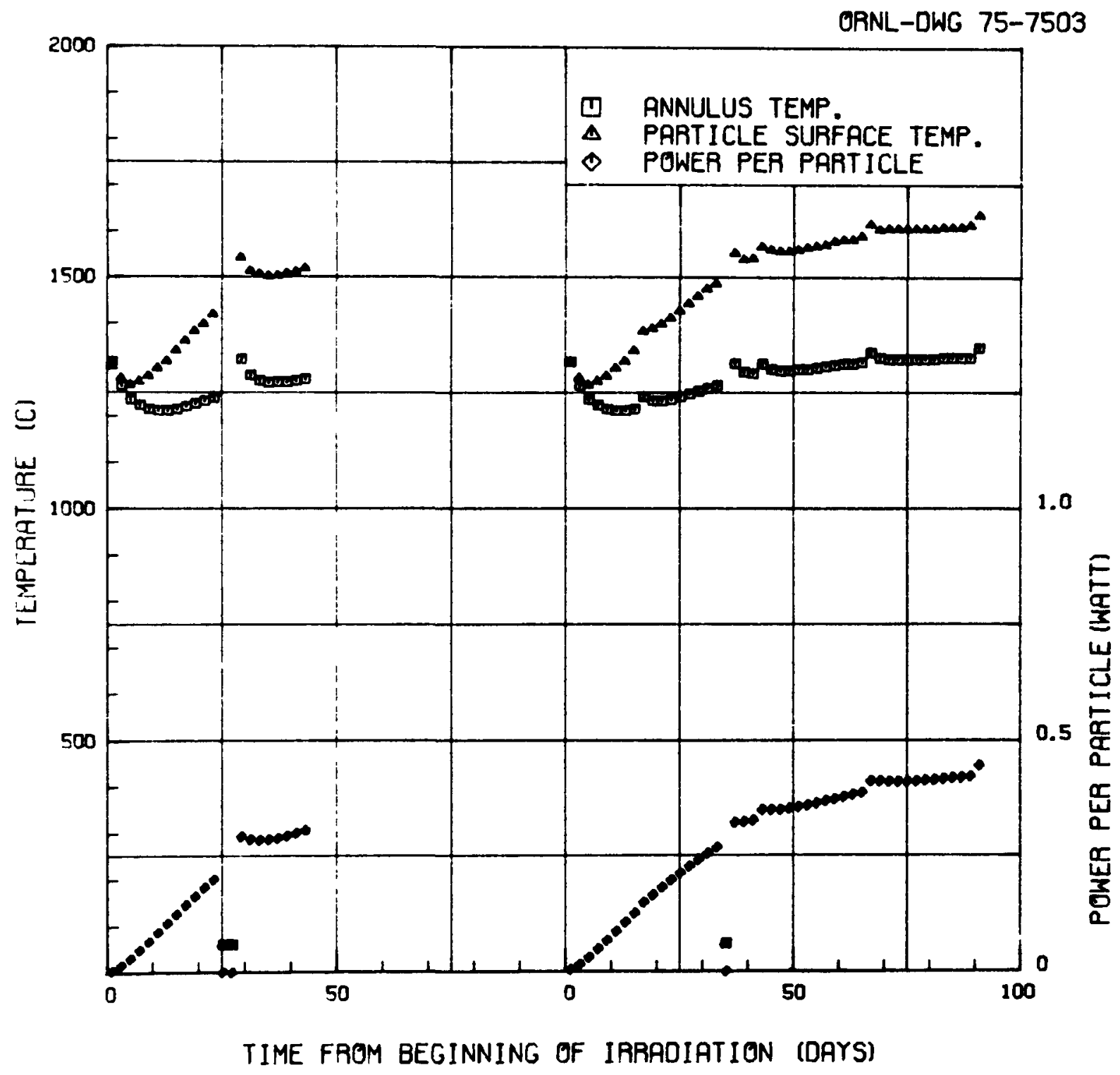

HT-12\&13 PART ICLE HOLDER 32 BATCH OR-1826 506.0 MICRON PARTICLE DIAMETER 


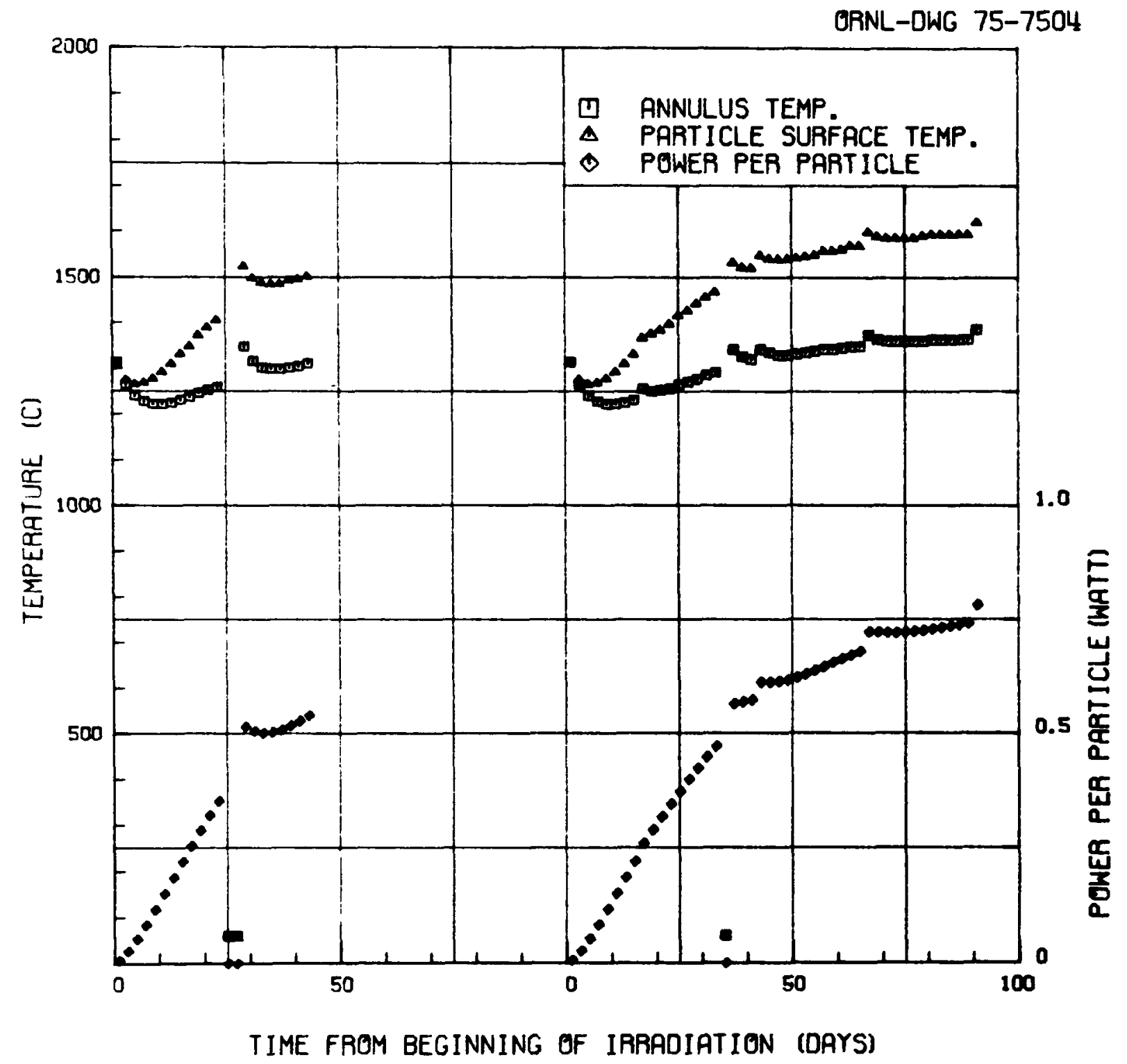

HT-12\$13 PART ICLE HOLDER 33 BATCH GA-4252-01
761.0 MICRON PART ICLE DIAMETER 


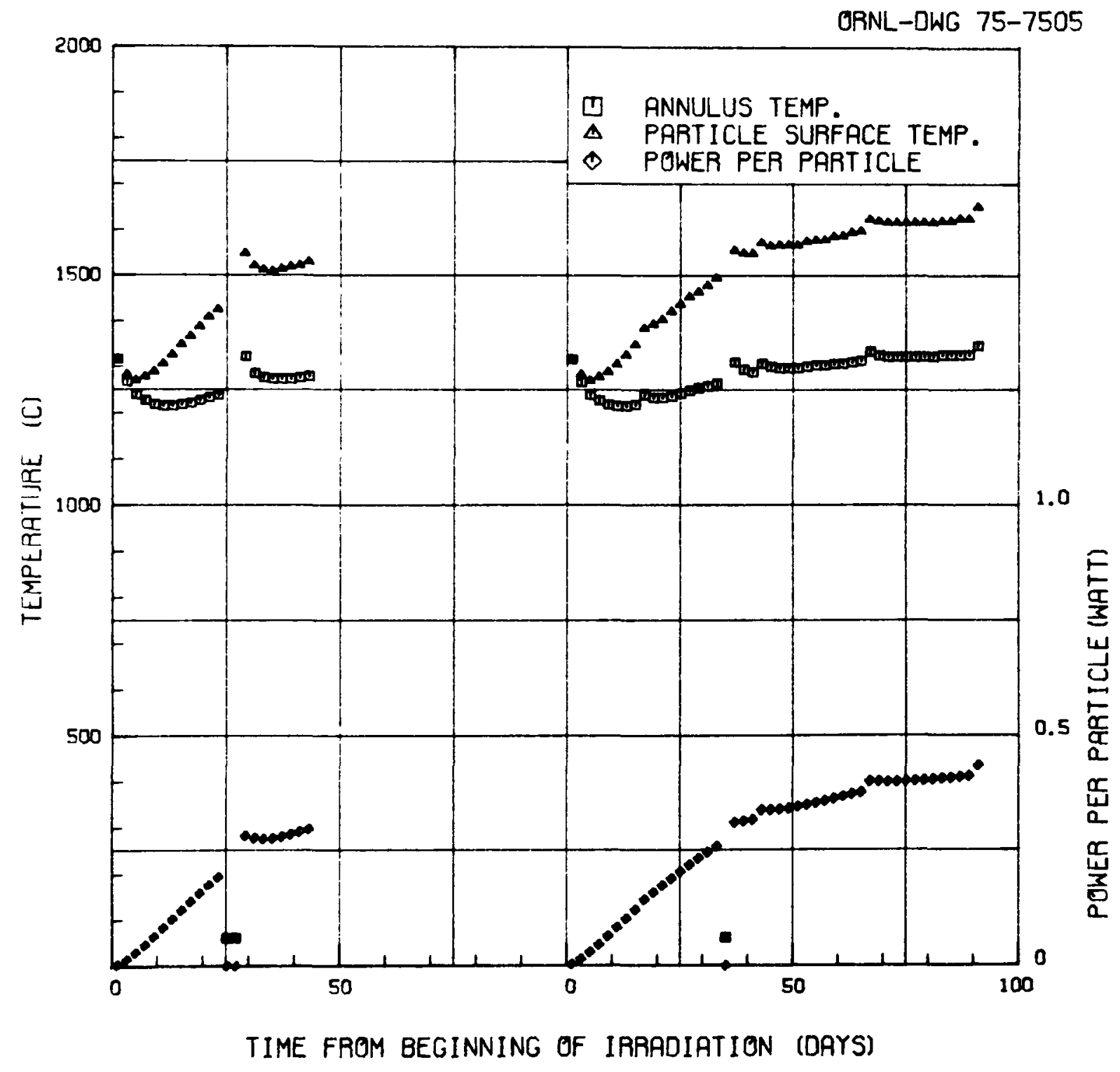
HT-12\$13 PARTICLE HOLDER 35 BATCH OR-1830
480.0 MICRON PARTICLE OIAMETER 
ORNL-OWG 75-7506

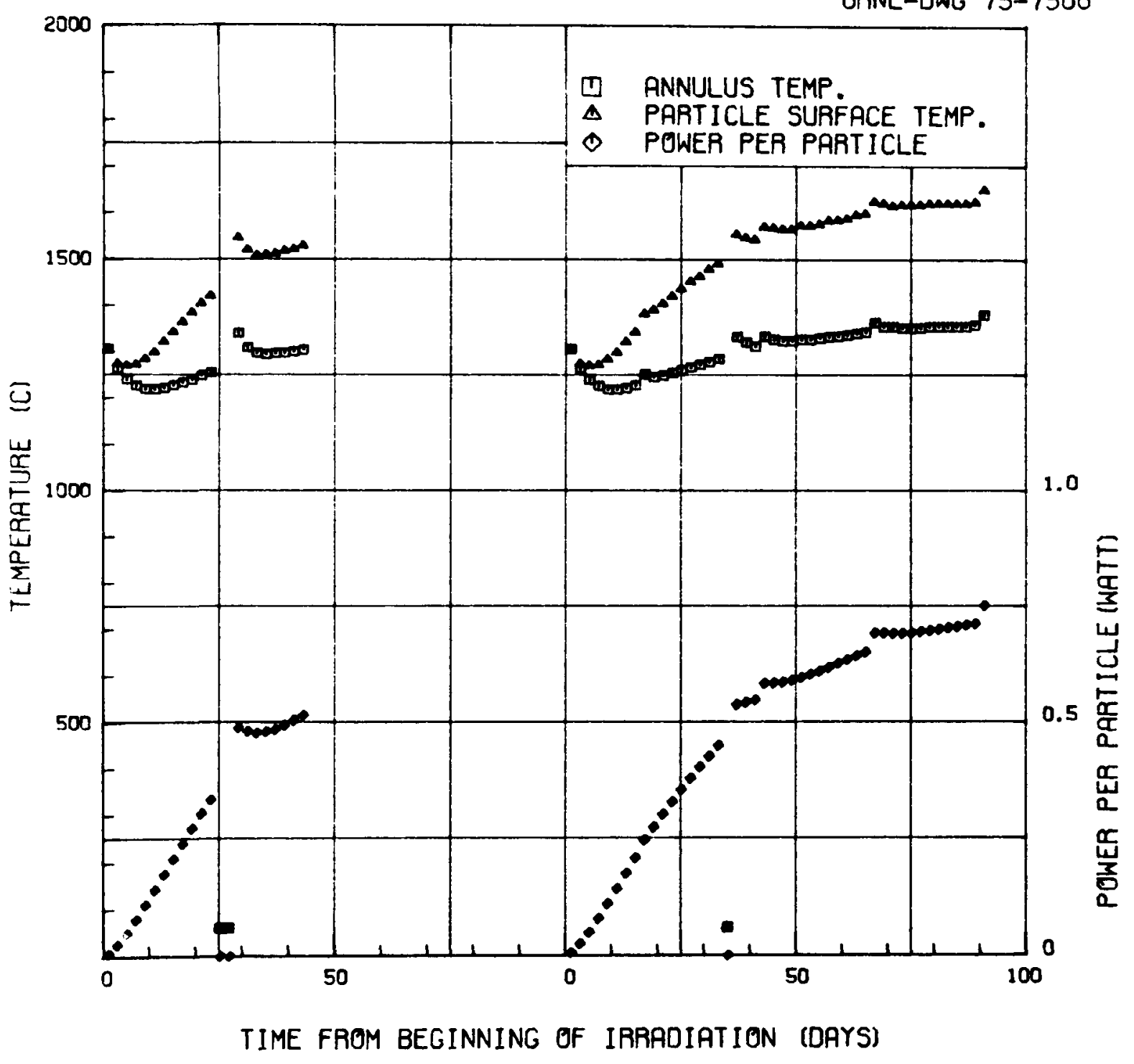

HT-12\$13 PART ICLE HOLDER 36 BATCH GA-4252-07 677.0 MICRON PART ICLE DIAMETER 
ORNL-DWG 75-7507

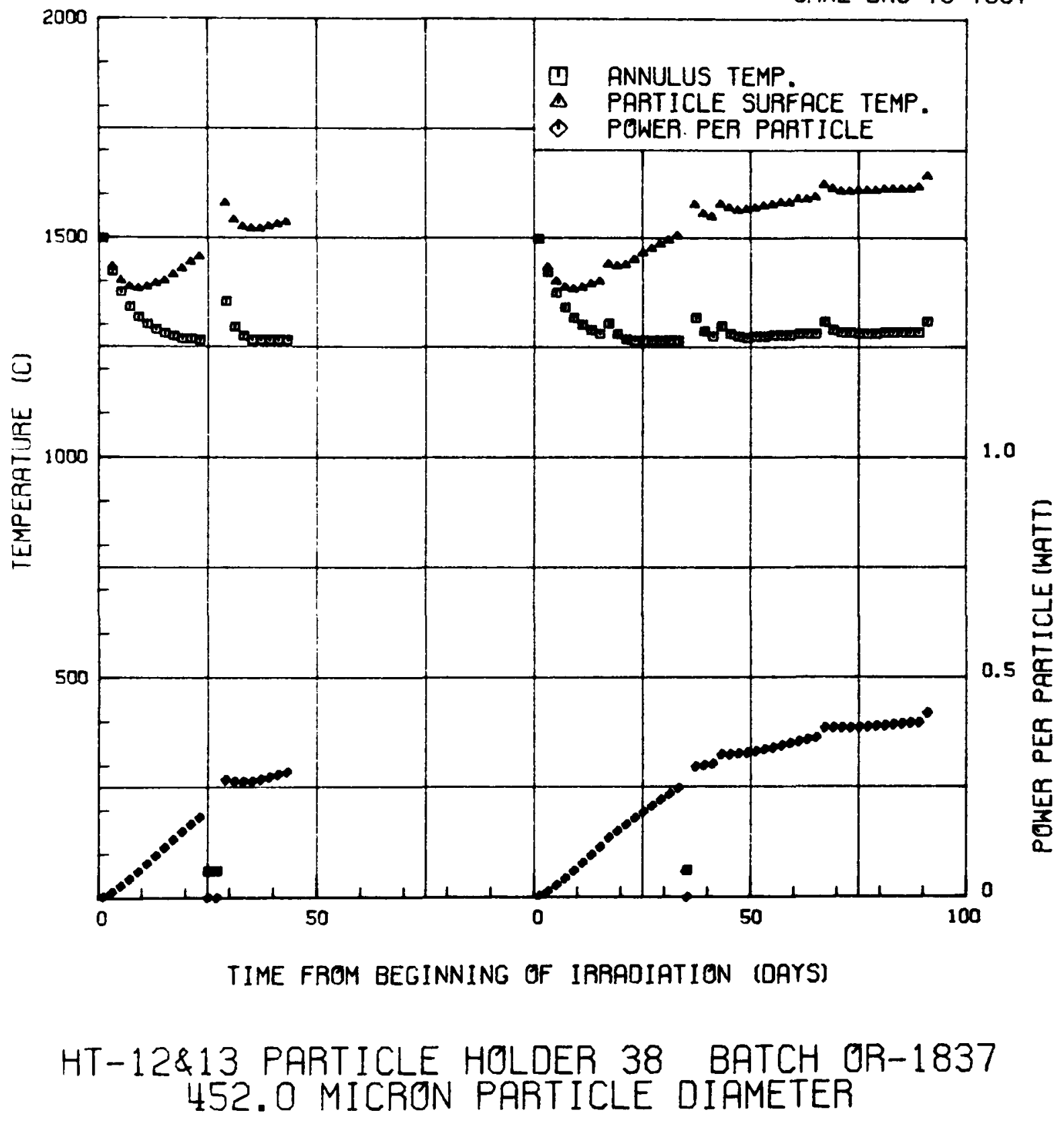




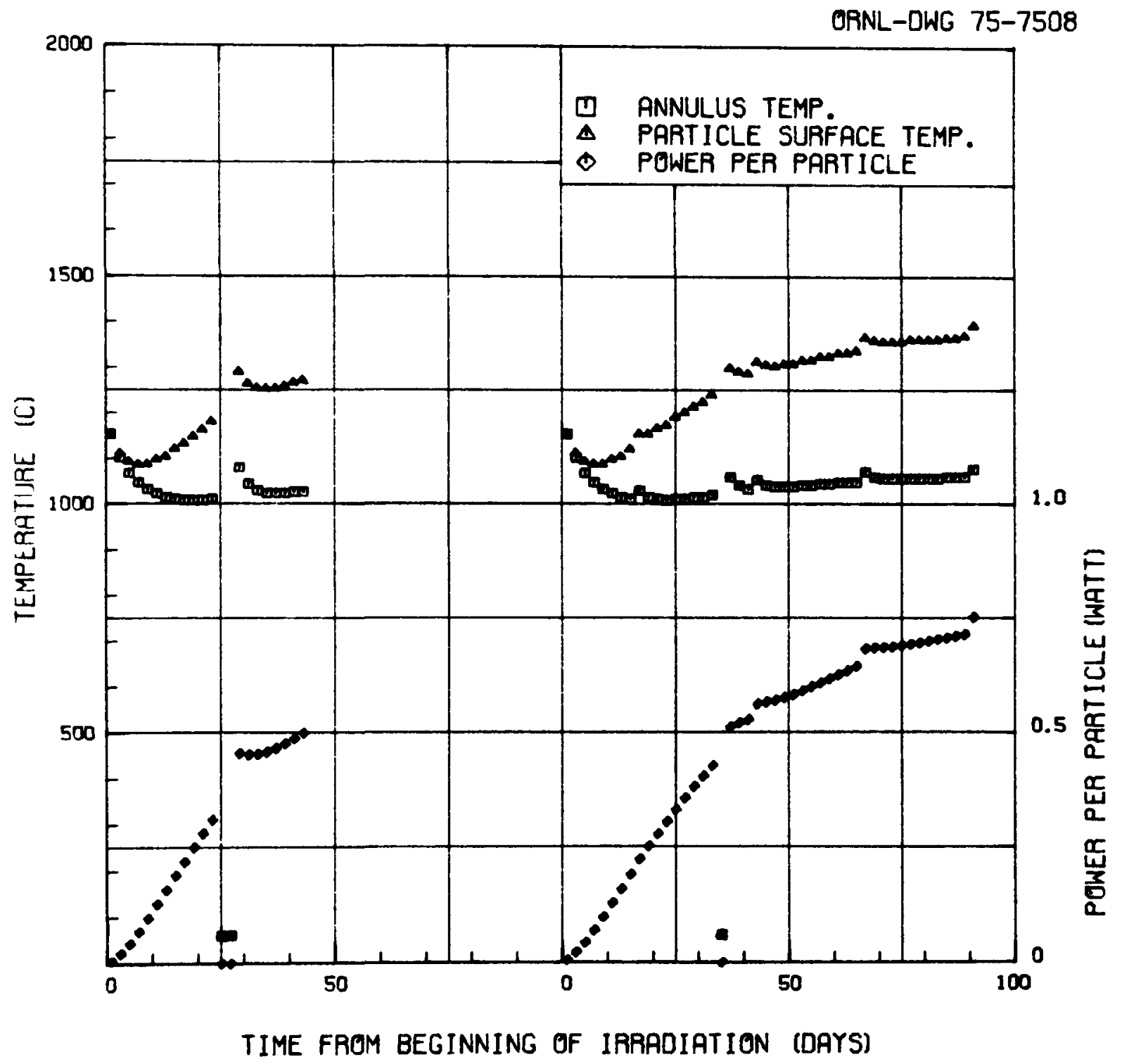

HT-12\&13 PARTICLE HOLDER 40 BATCH GA-4252-02 824.0 MICRON PART ICLE DIAMETER 


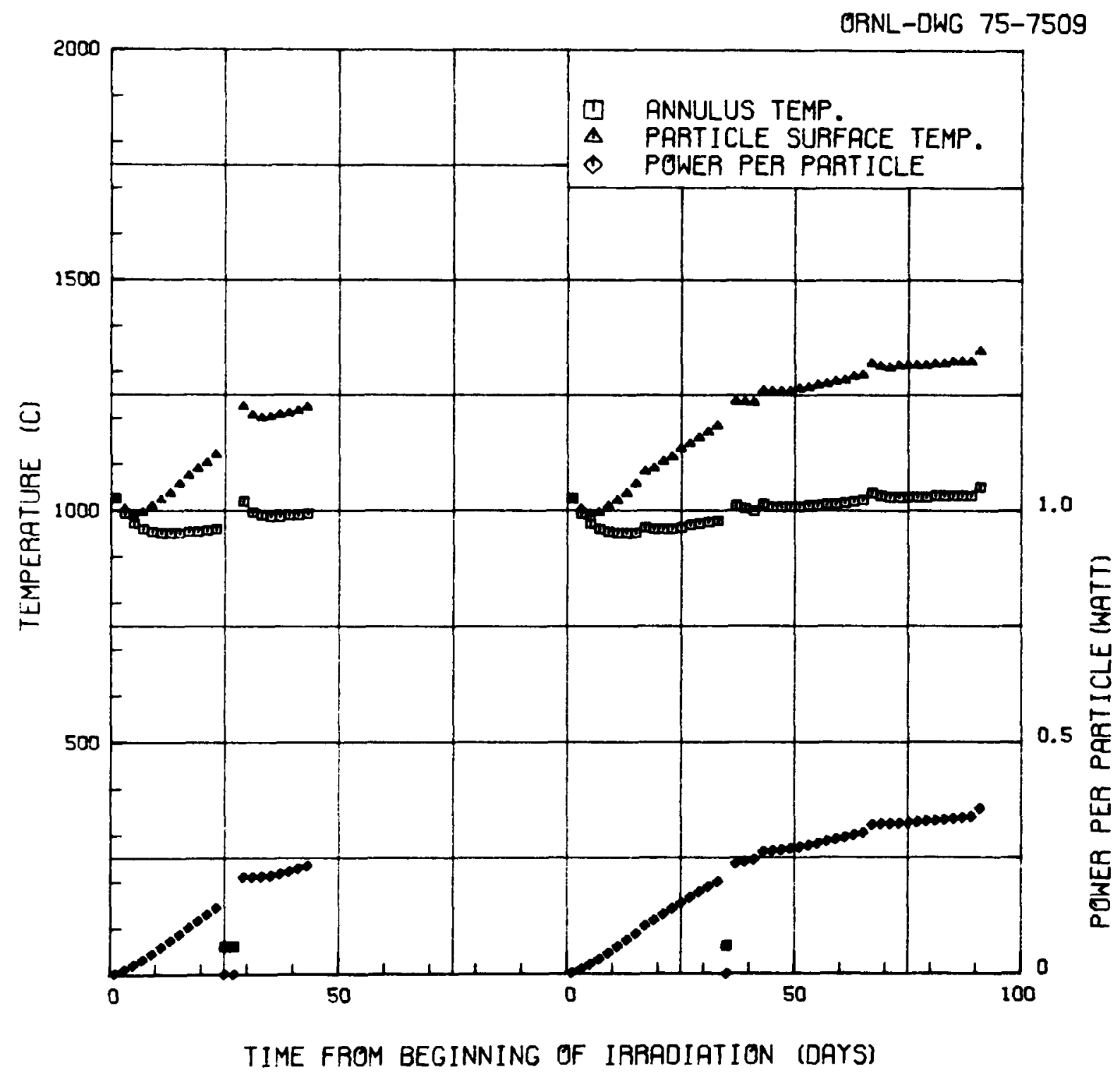

HT-12\&13 PARTICLE HOLDER 42 BATCH OR-1833 594. O MICRON PARTICLE DIAMETER 


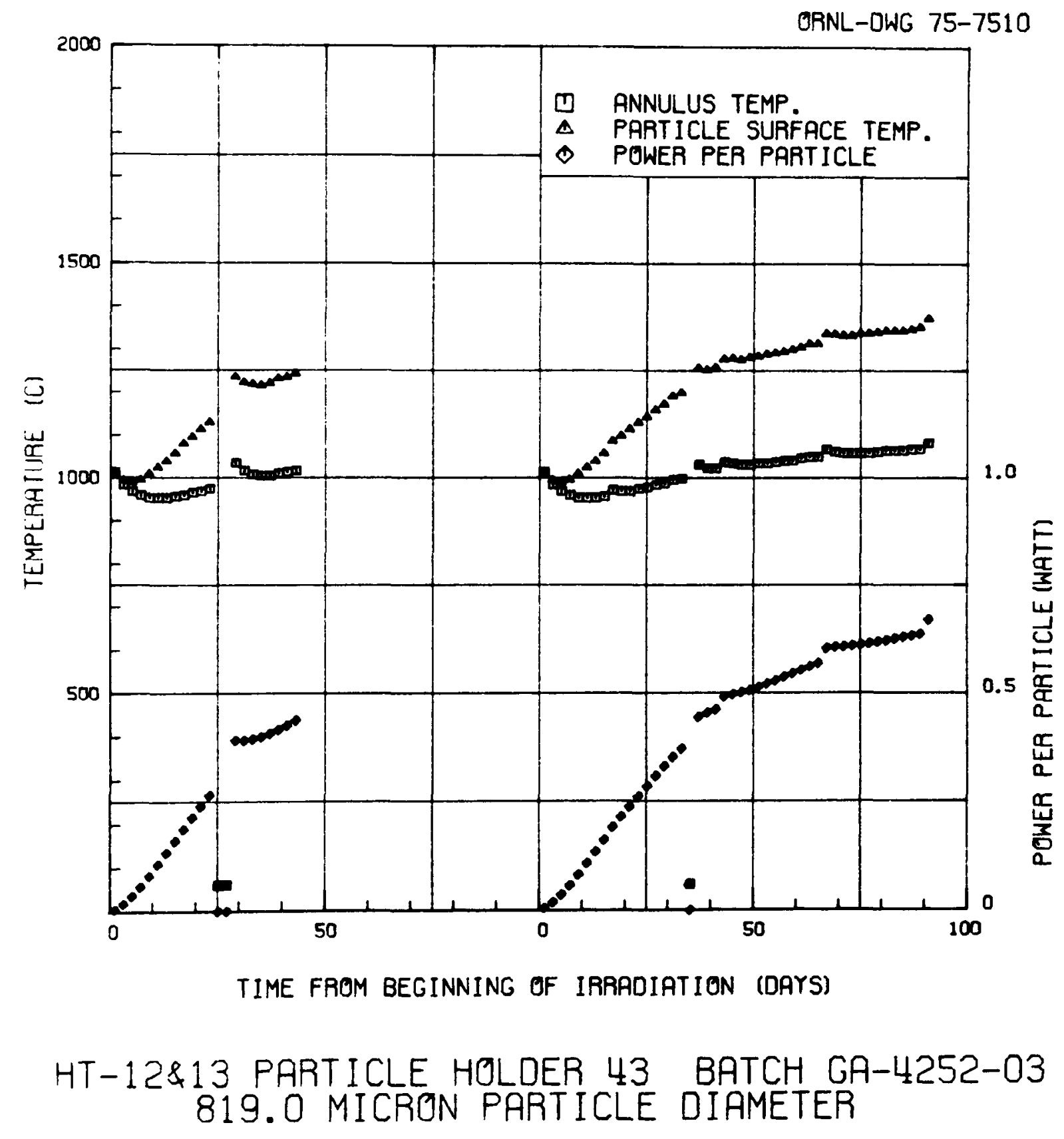




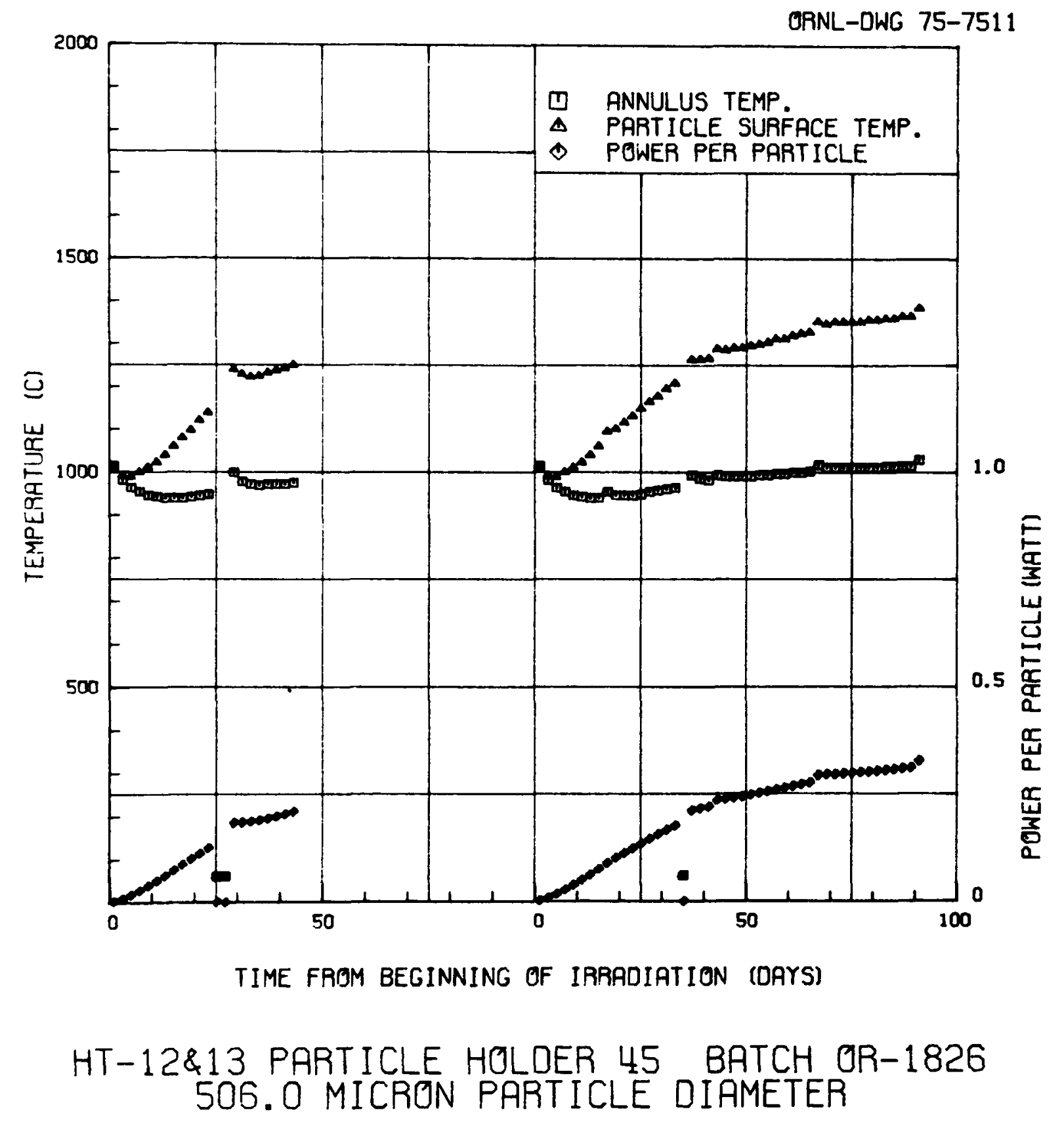




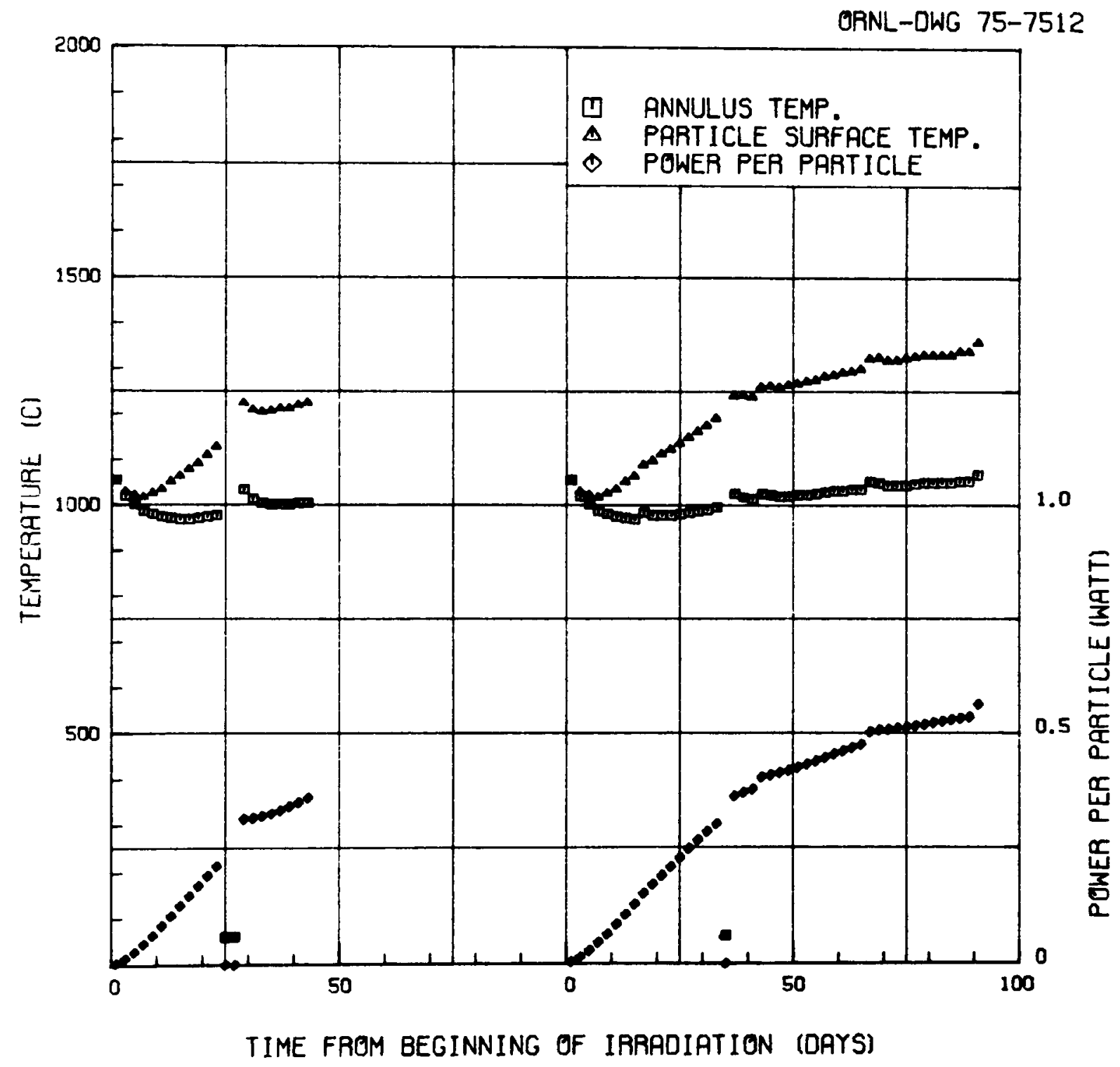

HT-12\&13 PARTICLE HOLDER 46 BATCH GA-4252-01 761.0 MICRON PARTICLE DIAMETER 
ORNL-DWG 75-7513

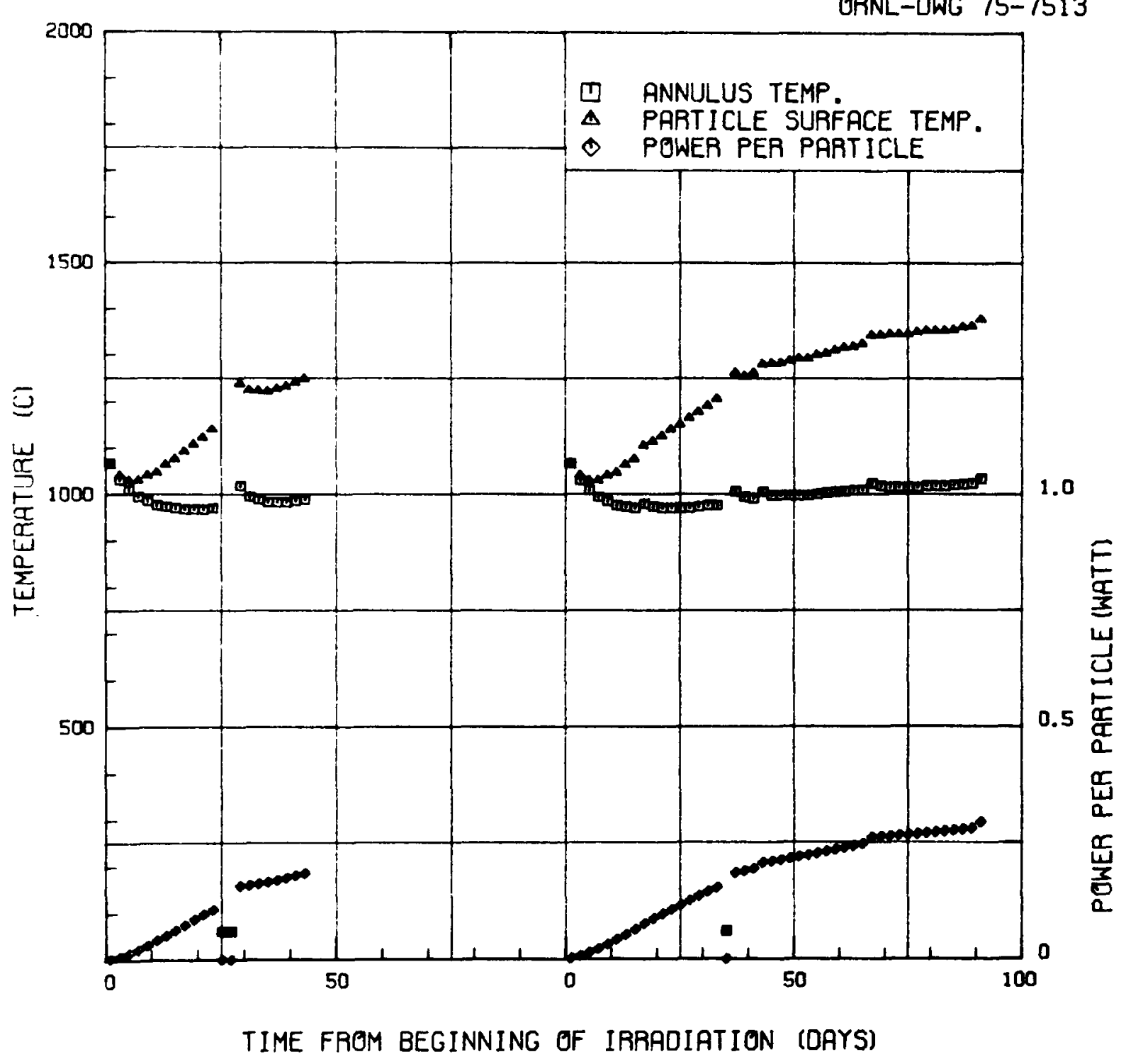

HT-12\&13 PARTICLE HOLDER 48 BATCH OR-1830 480.0 MICRON PARTICLE DIAMETER 


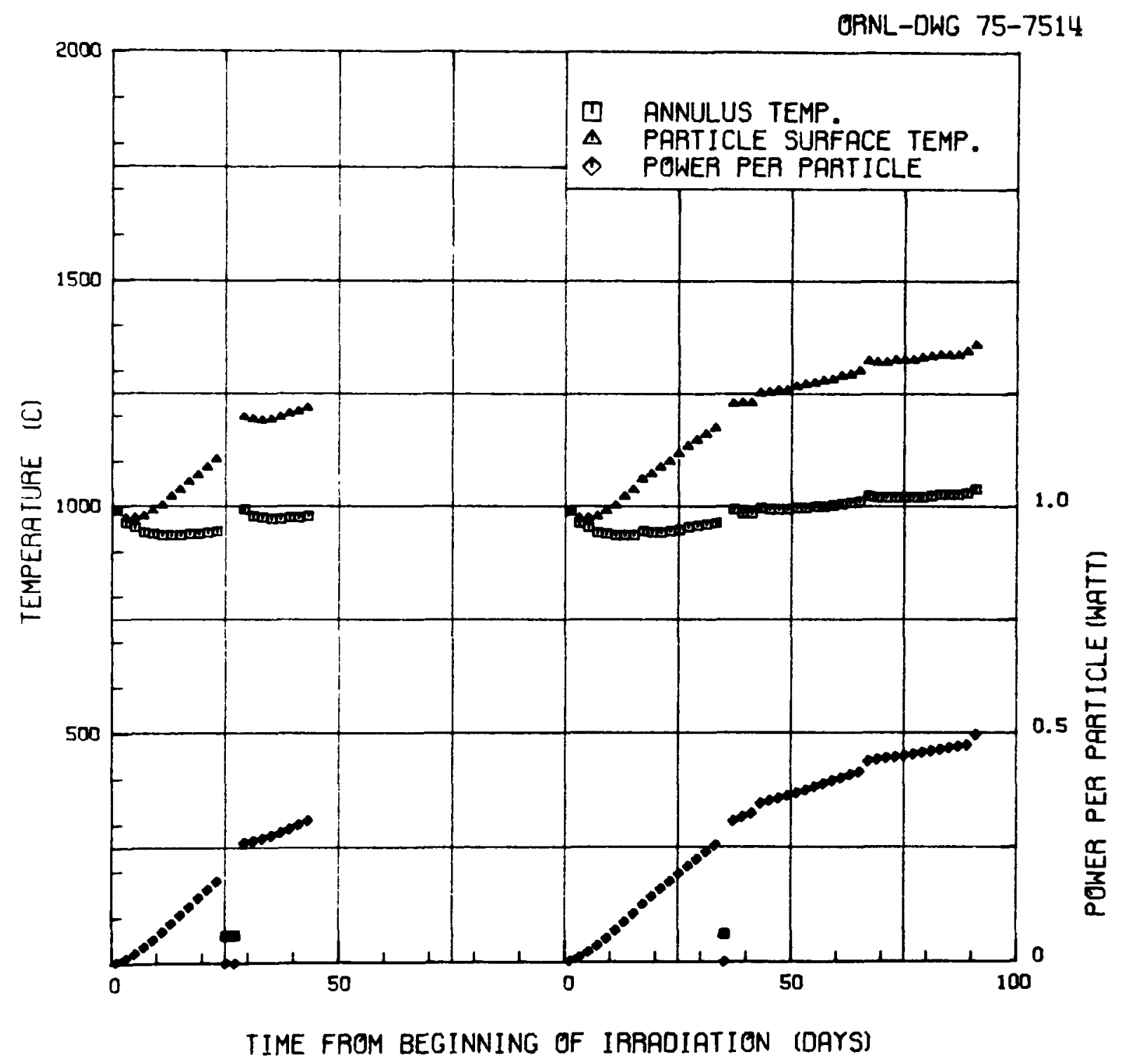

HT-12\&13 PARTICLE HOLDER 49 BATCH GA-4252-07 677. 0 MICRON PARTICLE DIAMETER 
ORNL-DWG 75-7515

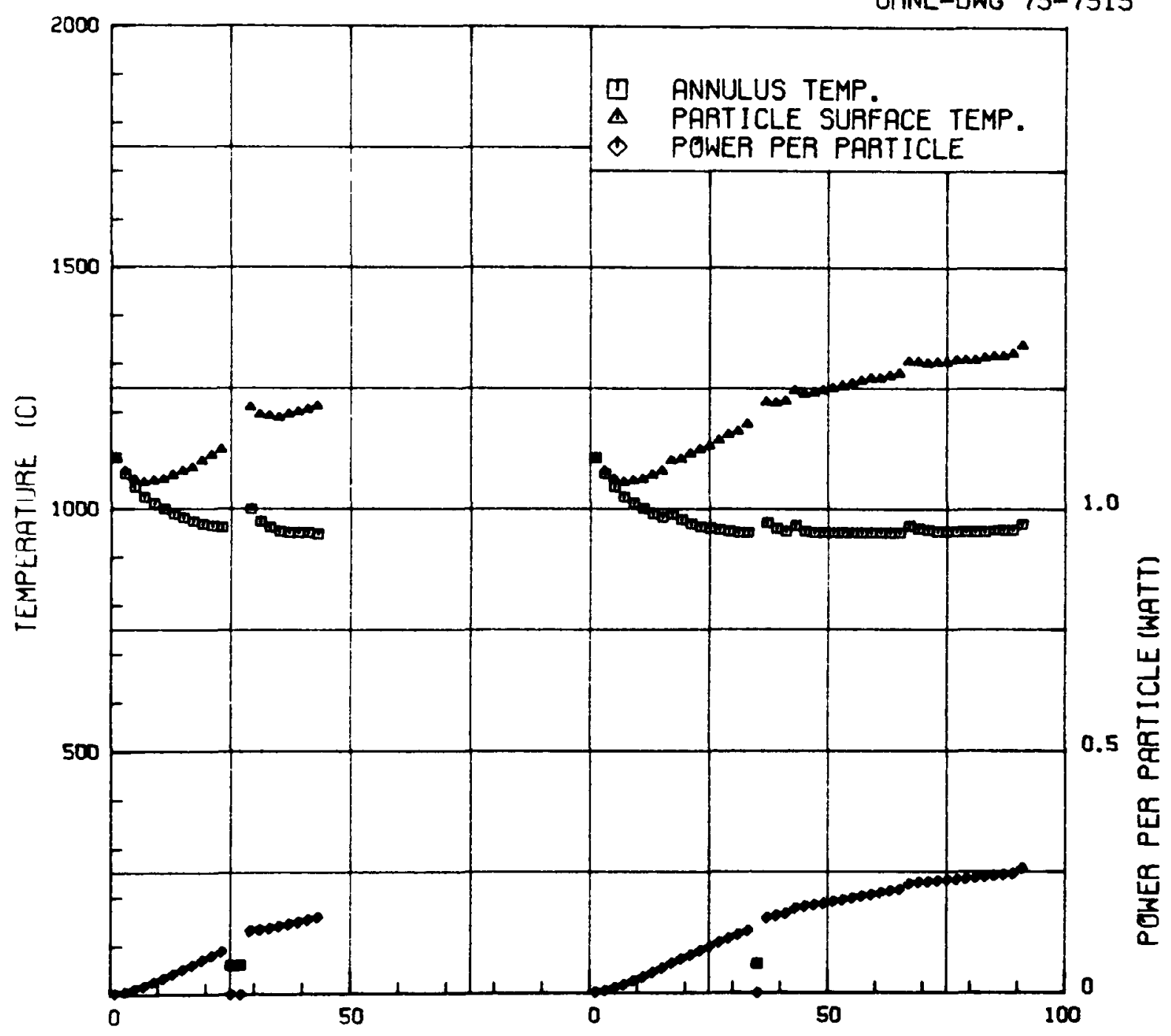

TIME FROM BEGINNING OF IRRADIATION (DAYS)

HT-12\&13 PART ICLE HOLDER 51 BATCH OR-1837

452.0 MICRON PARTICLE DIAMETER 
ORNL-DWG 75-7516

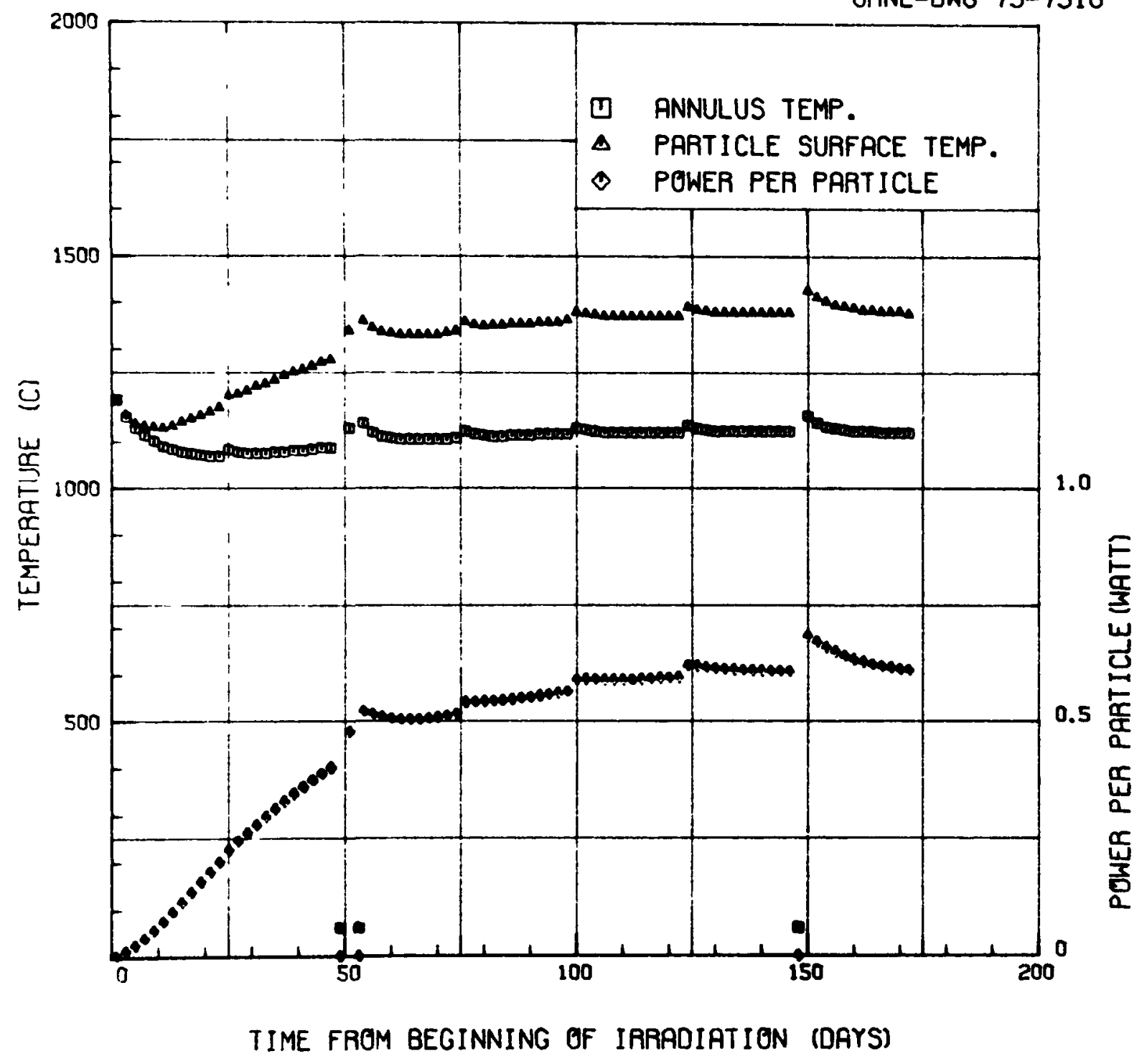

HT-14\&15 PARTICLE HOLDER 2 BATCH GA-4252-08 815.0 MICRON PARTICLE DIAMETER 


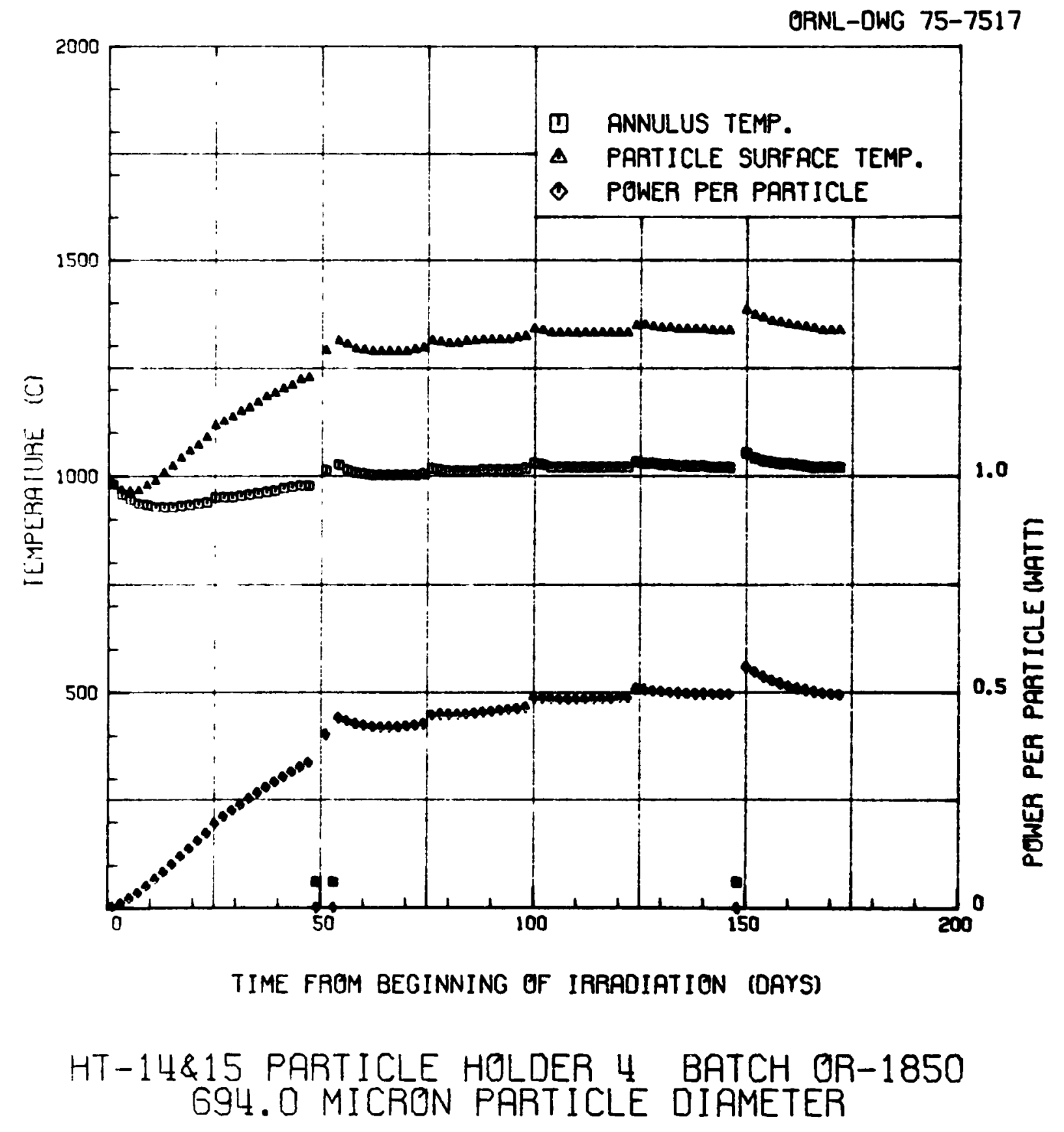


ORNL-OWG 75-7518

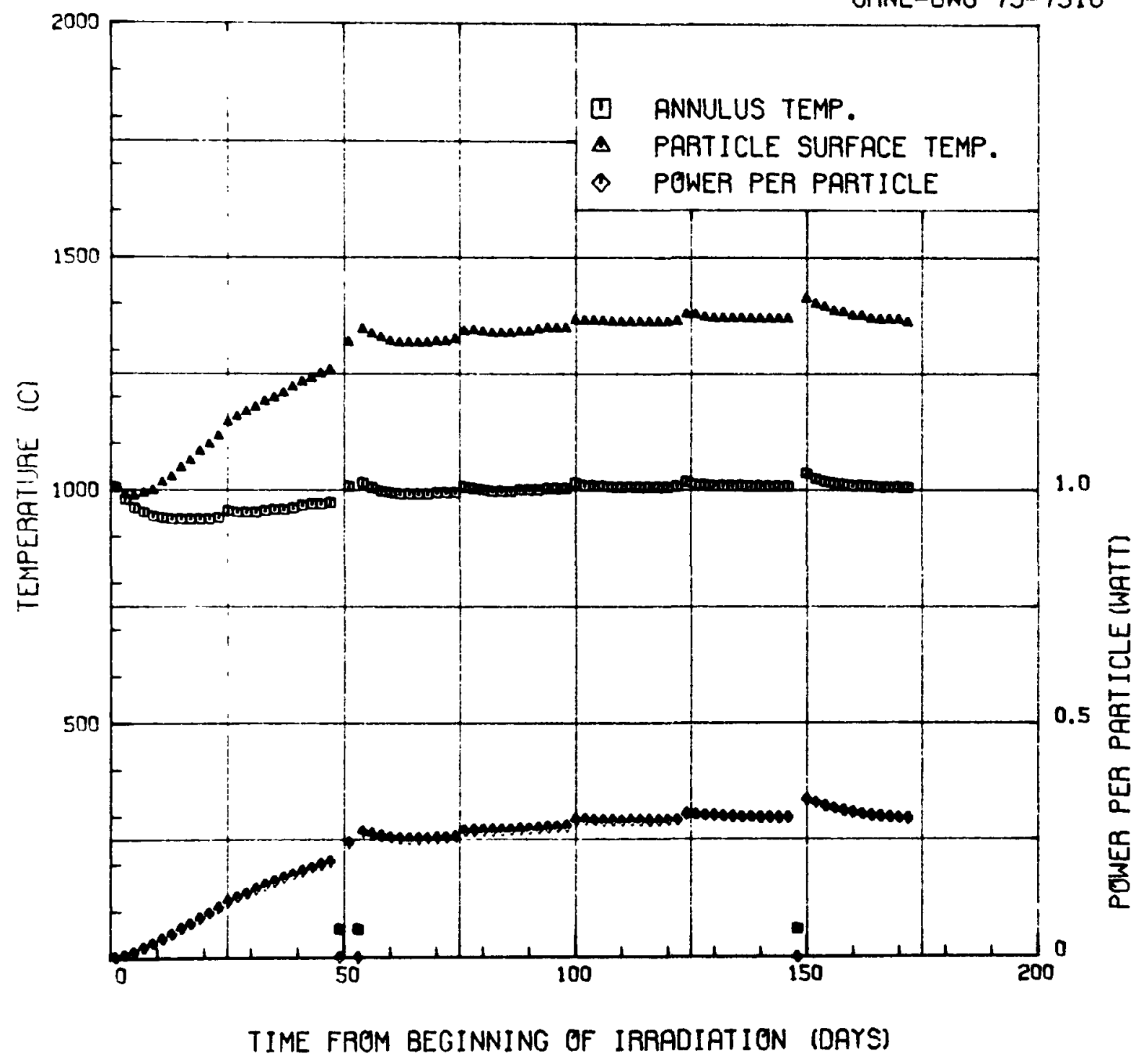

HT-14\&15 PARTICLE HOLDER 5 BATCH OR-1846 482.0 MICRON PARTICLE DIAMETER 
ORNL-OWG 75-7519

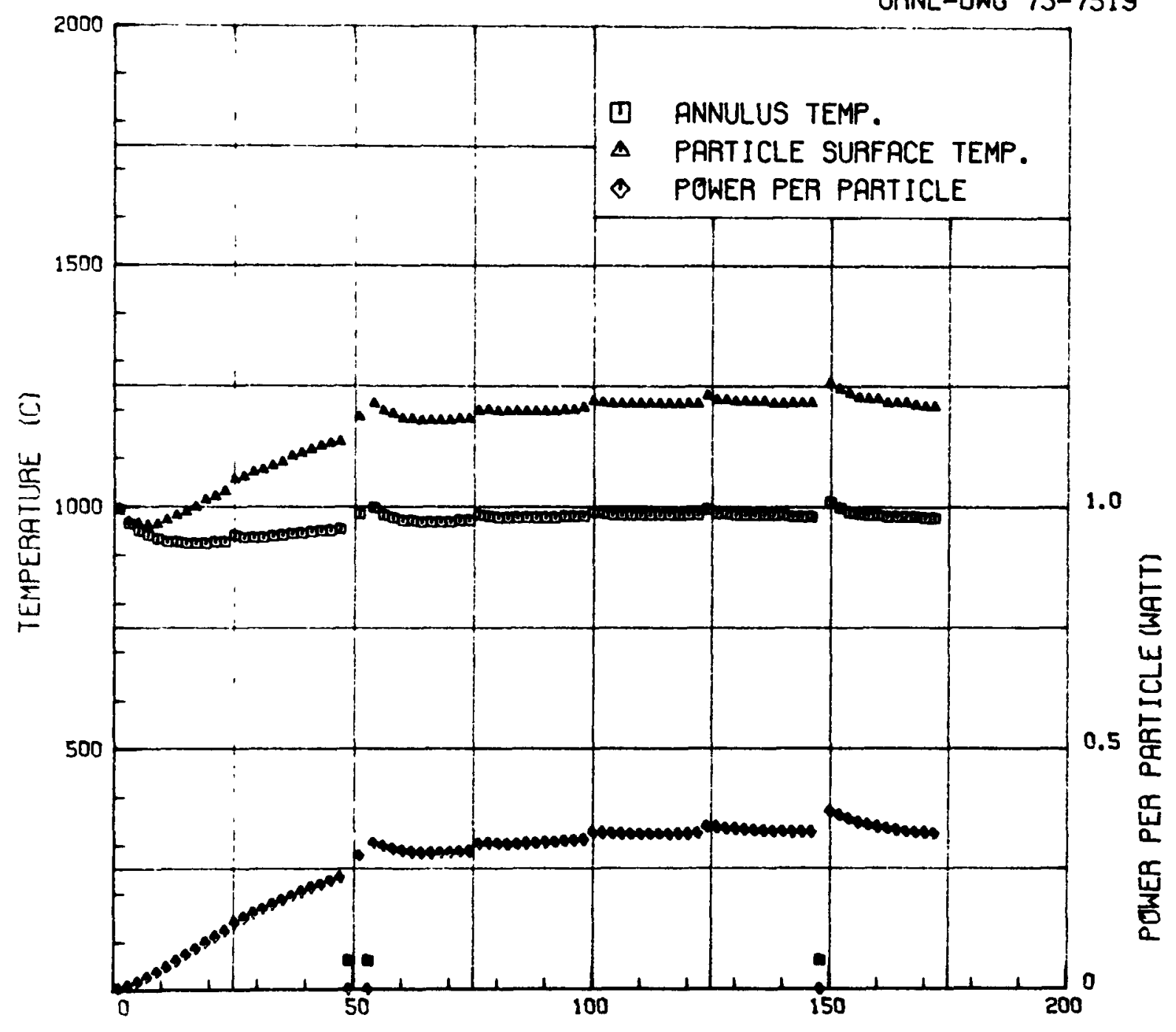

TIME FROM BEGINNING OF IRRADIATION (DAYS)

HT-14\&15 PART ICLE HOLDER 7 BATCH GA-4252-00 719.0 MICRON PARTICLE DIAMETER 


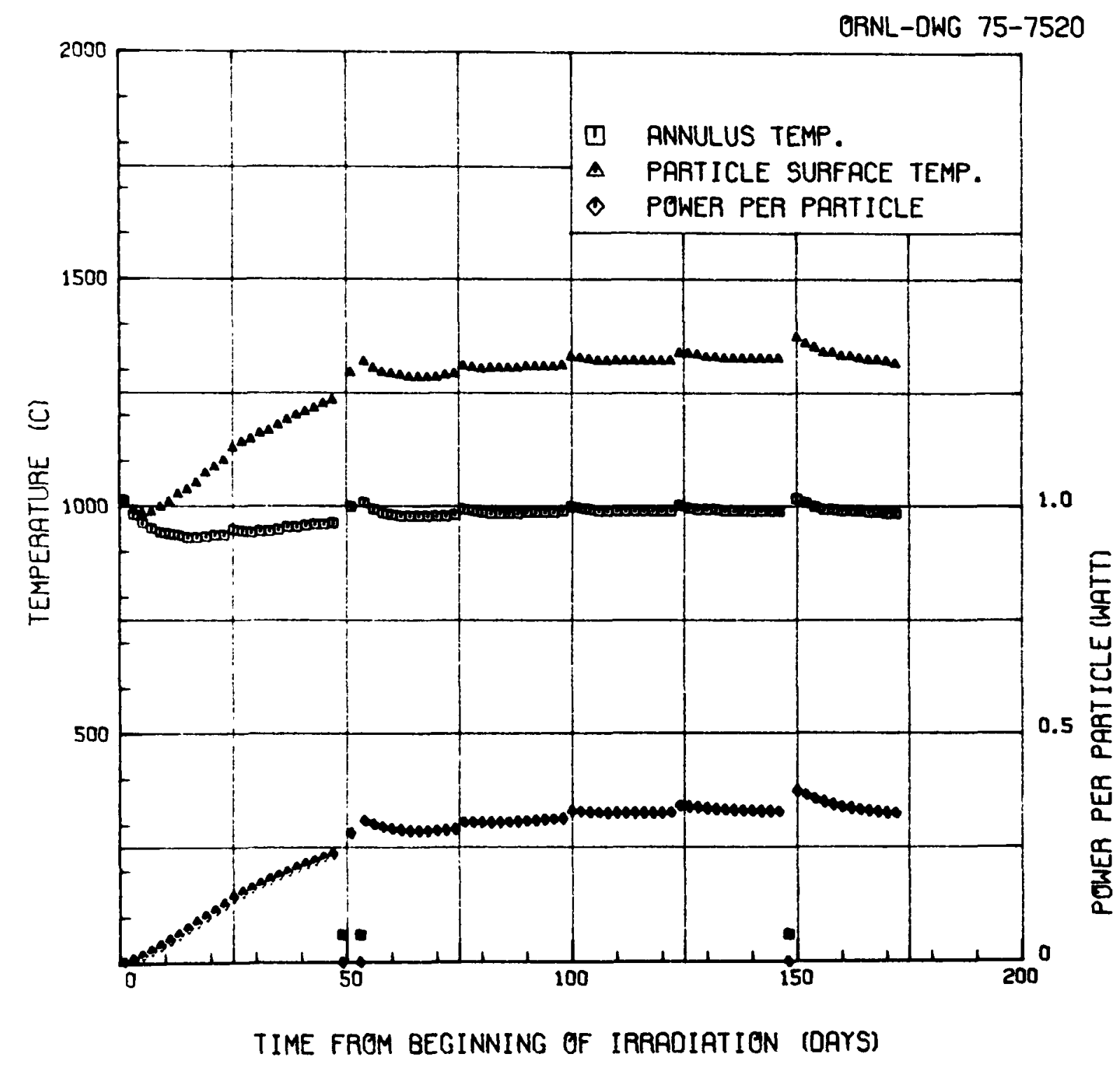

HT-14\&15 FARTICLE HOLDER 8 BATCH OR-1840 552. O MICRON PRRTICLE DIAMETER 


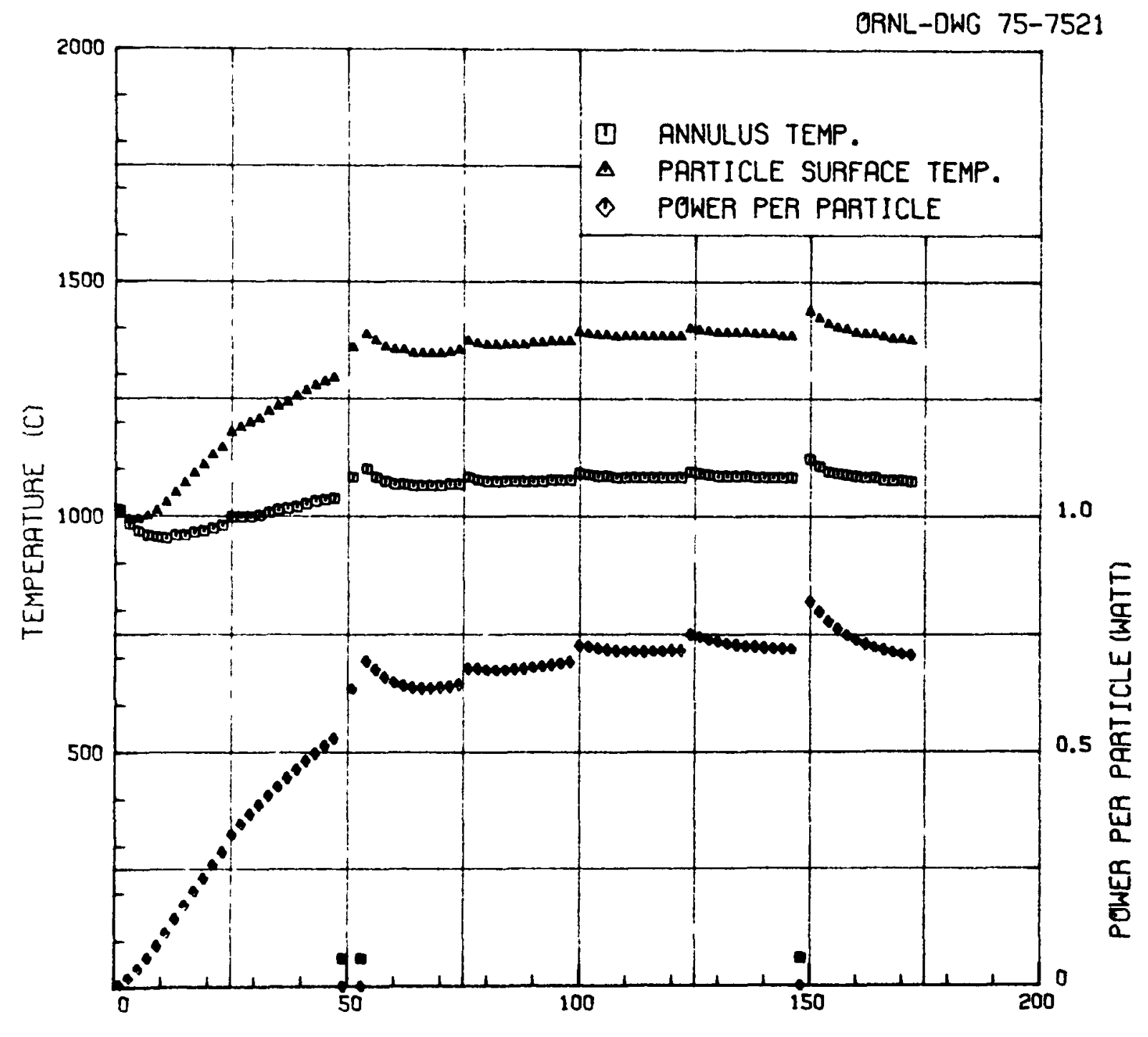

TIME FROM BEGINNING OF IRRADIATION (DAYS)

HT-14\&15 PARTICLE HOLDER 10 BATCH GA-4252-06 822.0 MICRON PART ICLE DIAMETER 


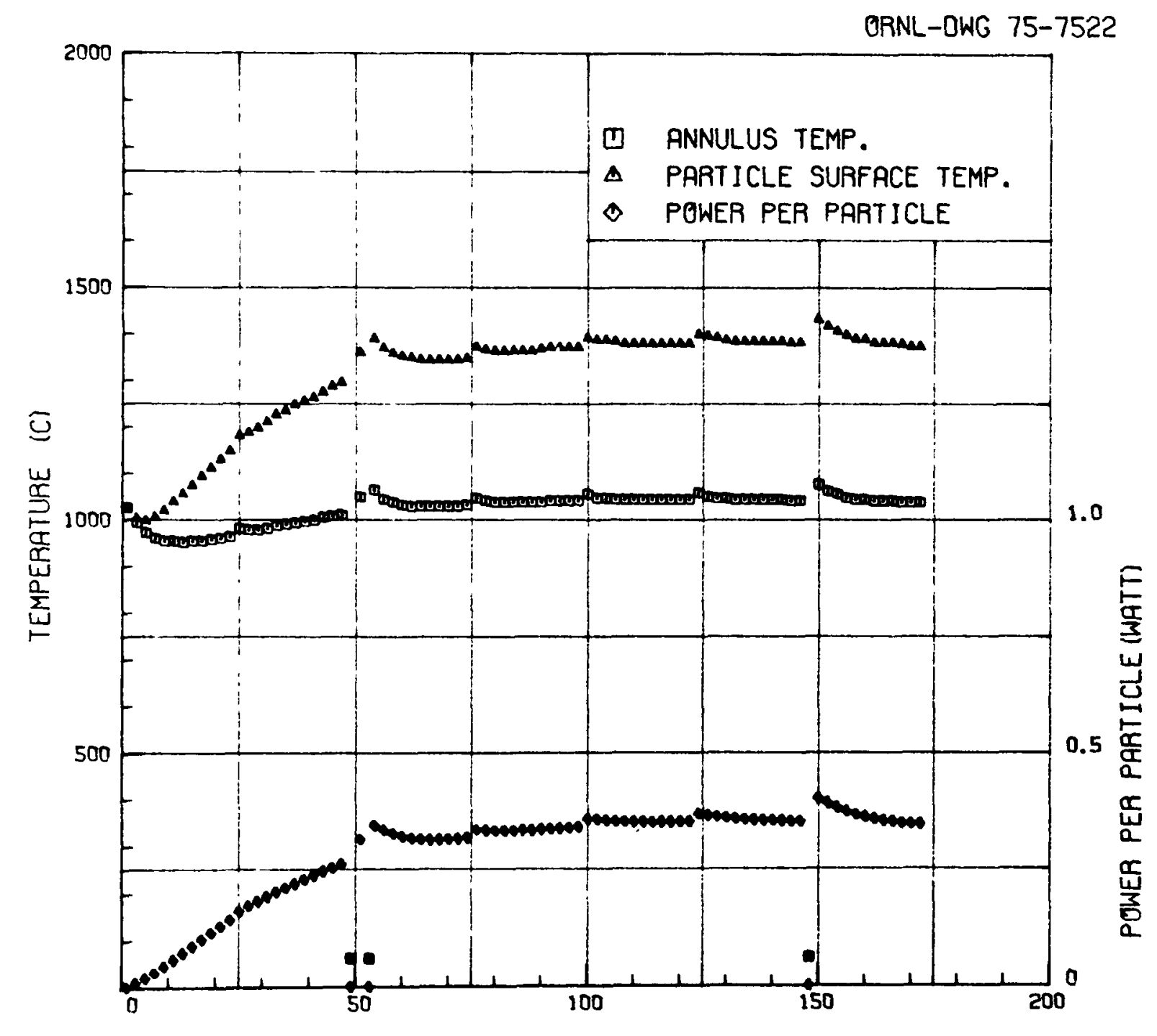

TIME FROM BEGINNING OF IRRADIATION (DAYS)

HT-14\&15 PARTICLE HOLDER 11 BATCH OR-1749 540.0 MICRON PARTICLE DIAMETER 


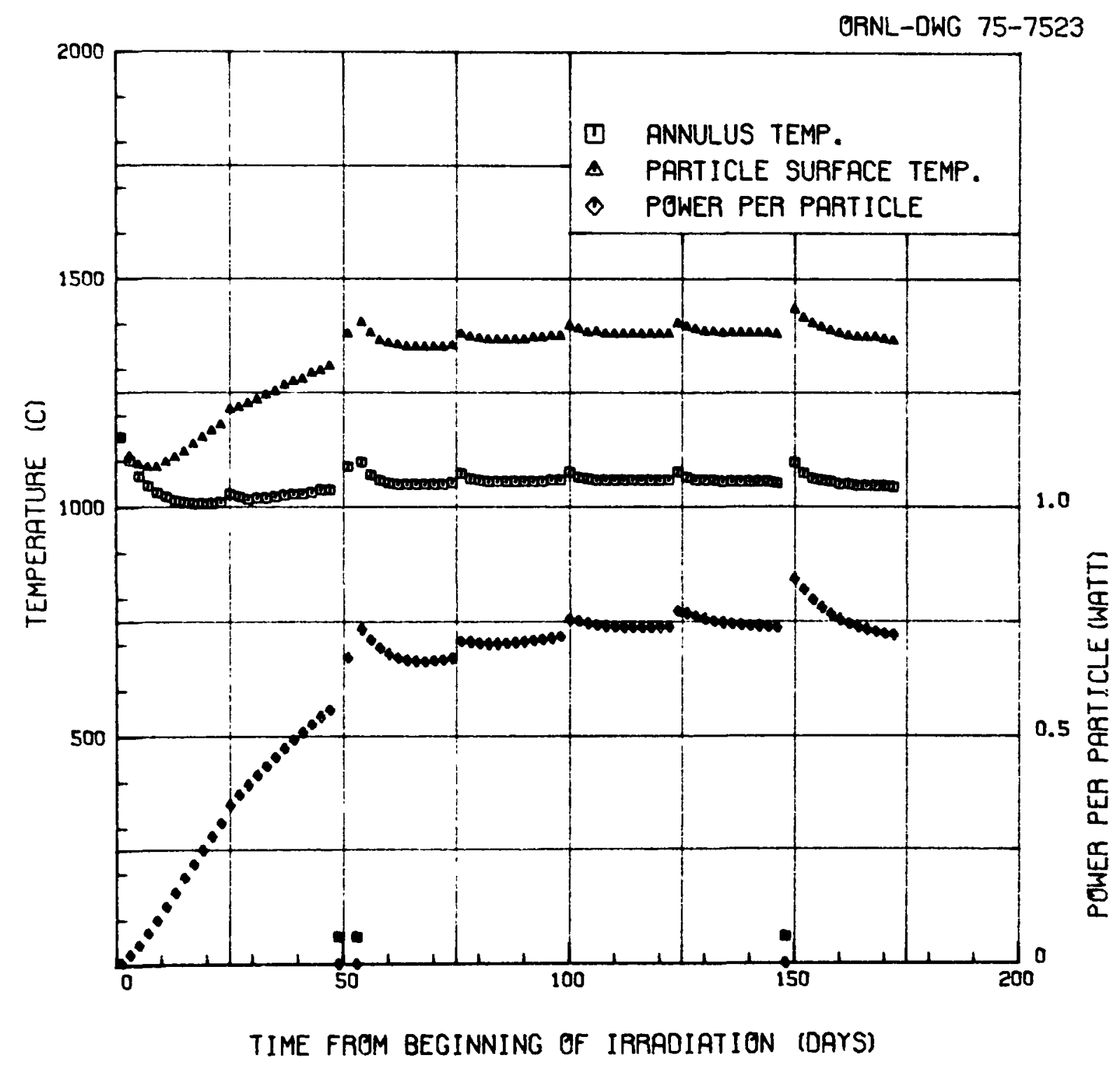

HT-14\&15 PARTICLE HOLDER 13 BATCH OR-1849 816.0 MICRON PARTICLE DIAMETER 


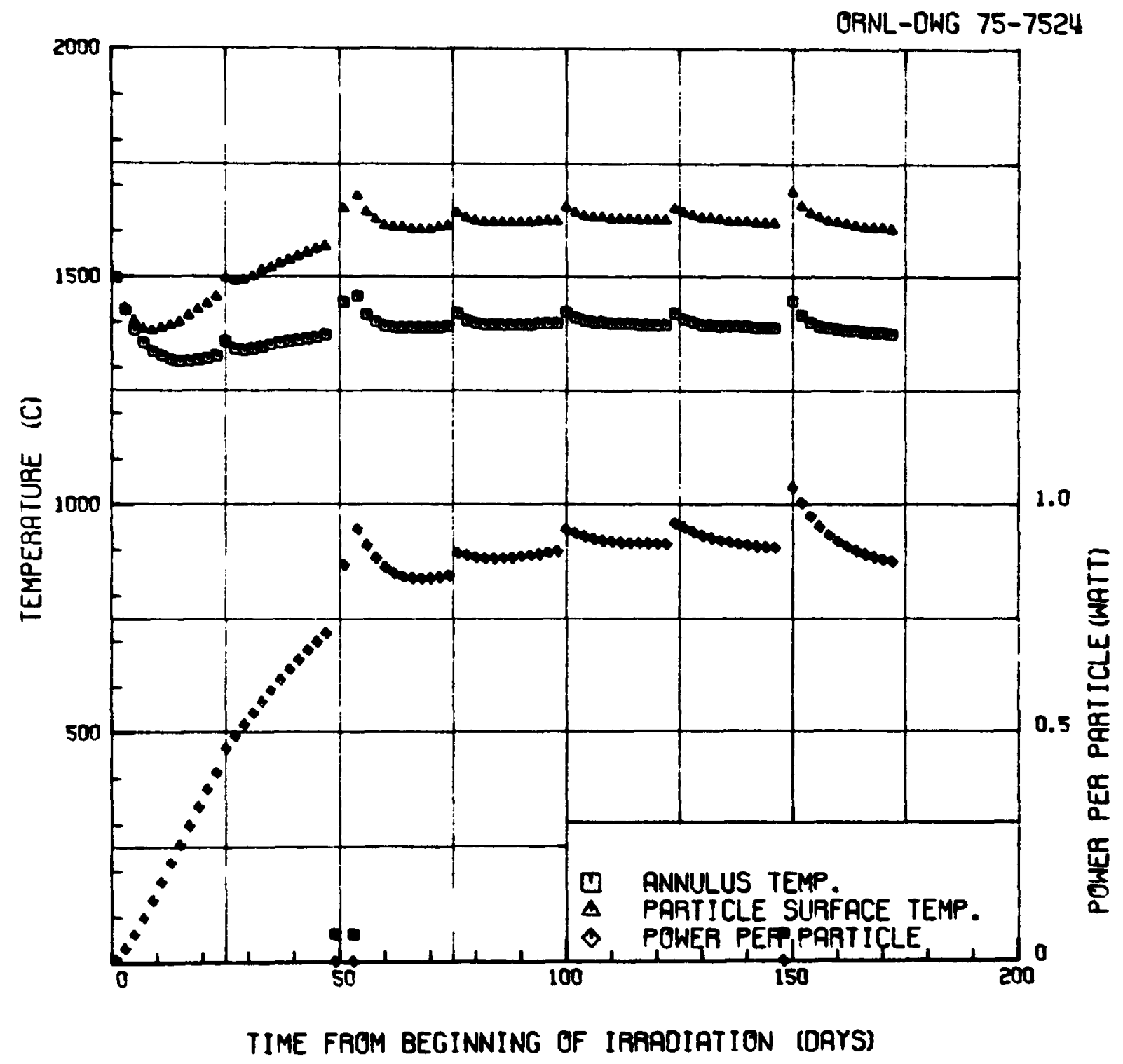

HT-14\&15 PARTICLE HOLDER 15 BATCH GA-4252-08 815.0 MICRON PARTICLE DIAMETER 


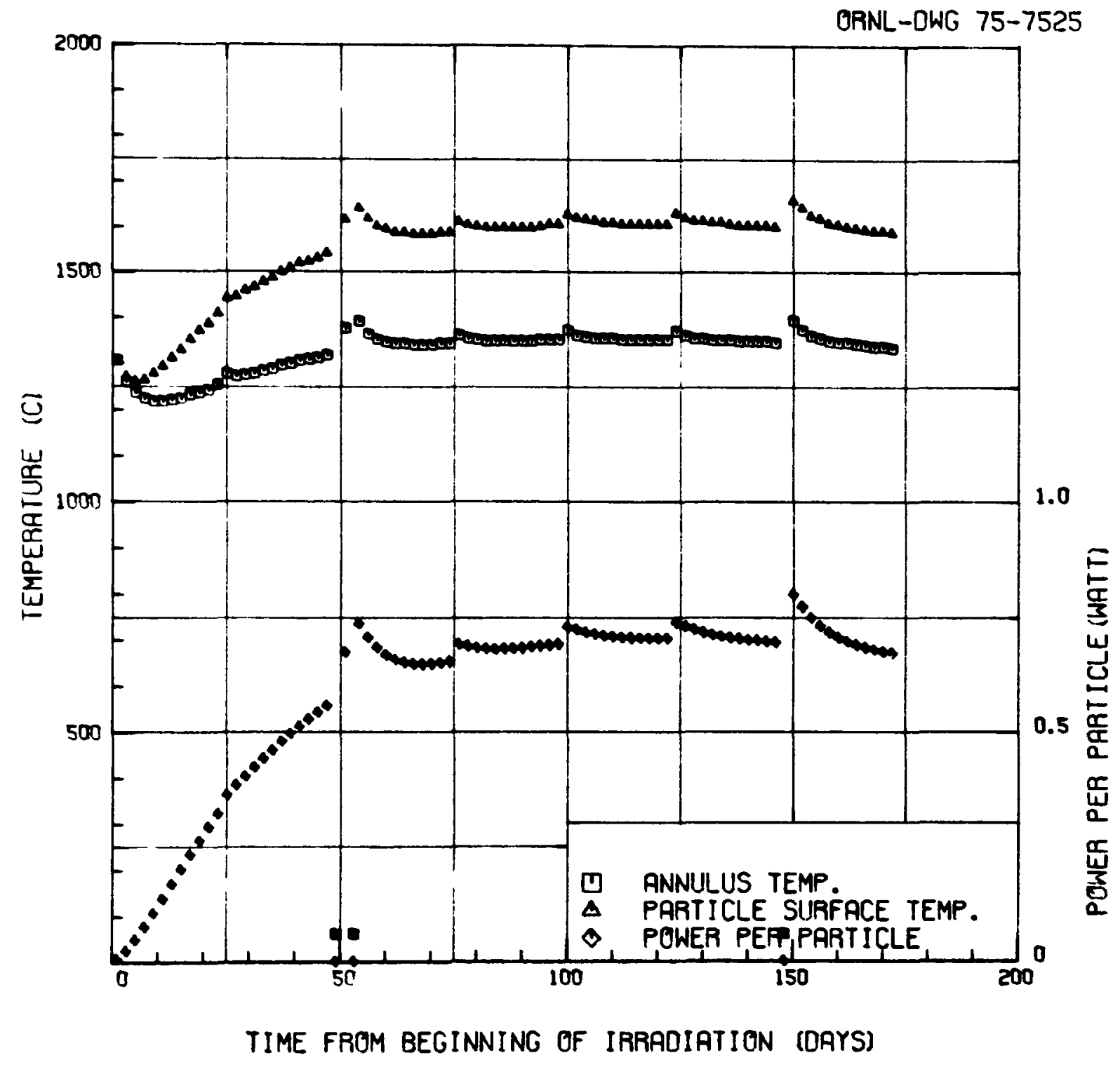

HT-14\&15 PARTICLE HOLDER 17 BATCH OR-1850 694.0 MICRON PARTICLE DIAMETER 


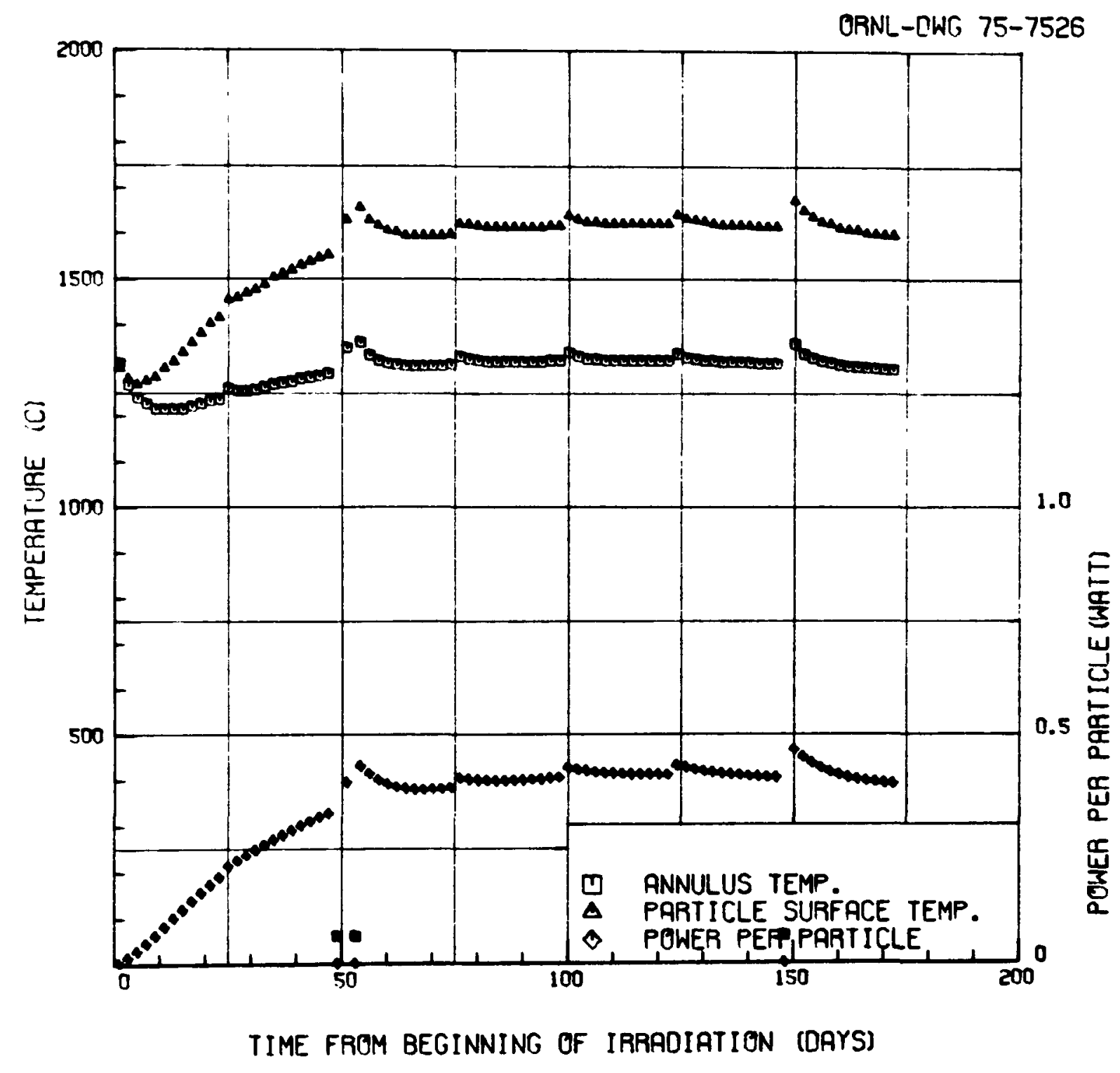

HT-14\&15 PARTICLE HOLDER 18 BATCH OR-1846 482. O MICRON PARTICLE OIAMETER 


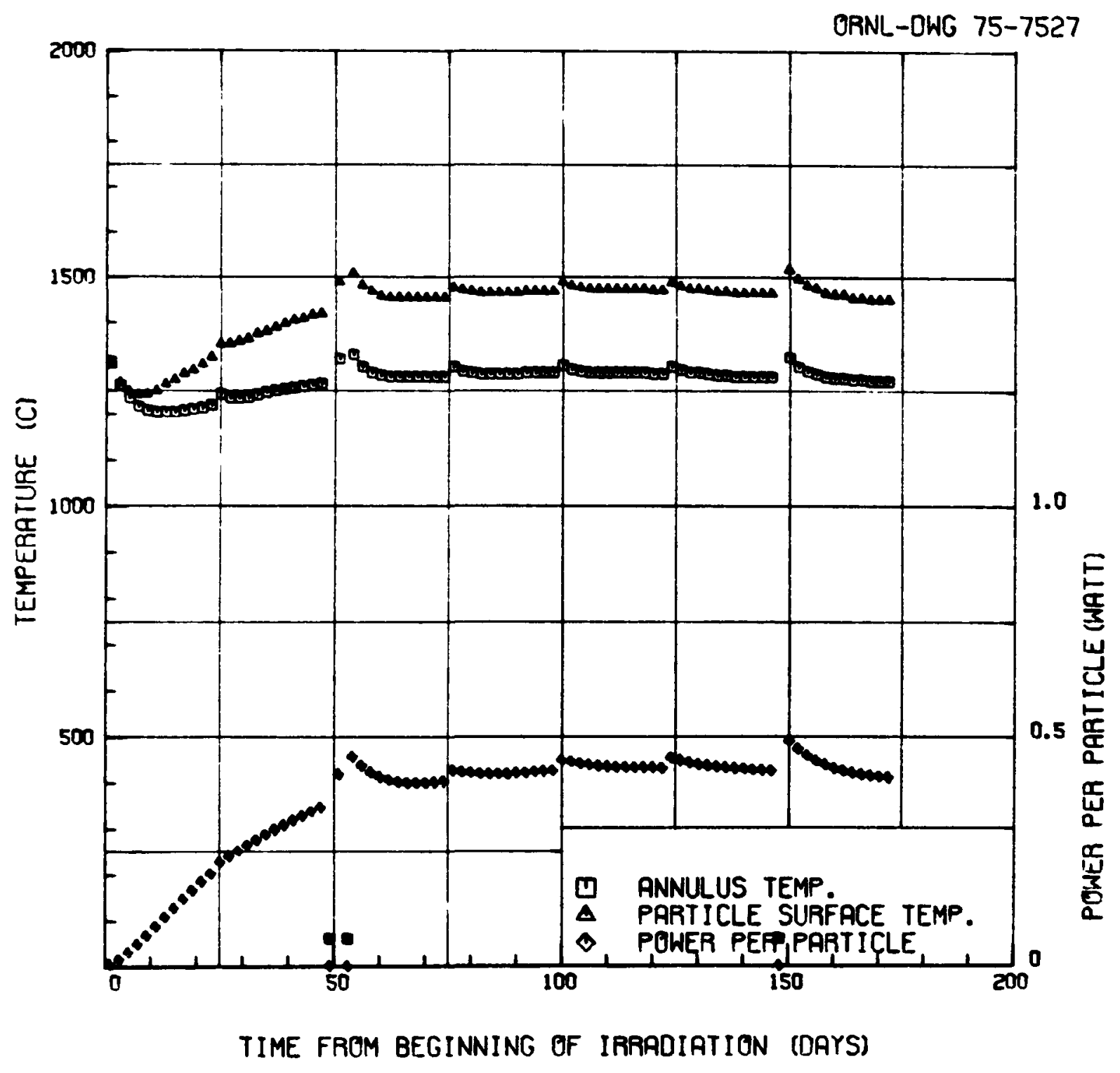

HT-14\&15 PARTICLE HOLDER 20 BATCH GA-4252-00
719.0 MICRON PART ICLE DIAMETER 


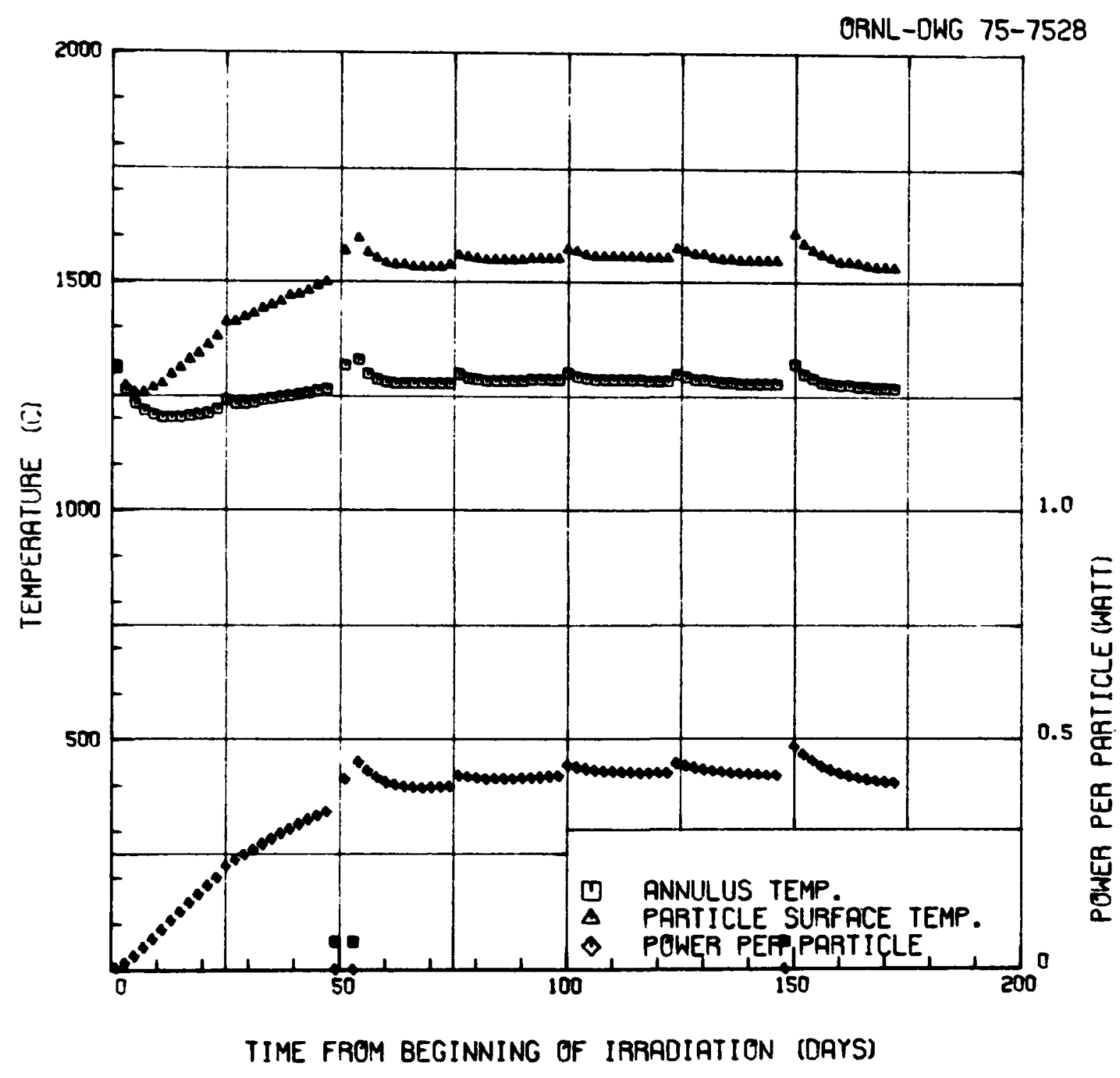

HT-14\&15 PARTICLE HOLDER 21 BATCH OR-1840
552.0 MICRON PARTICLE DIAMETER 


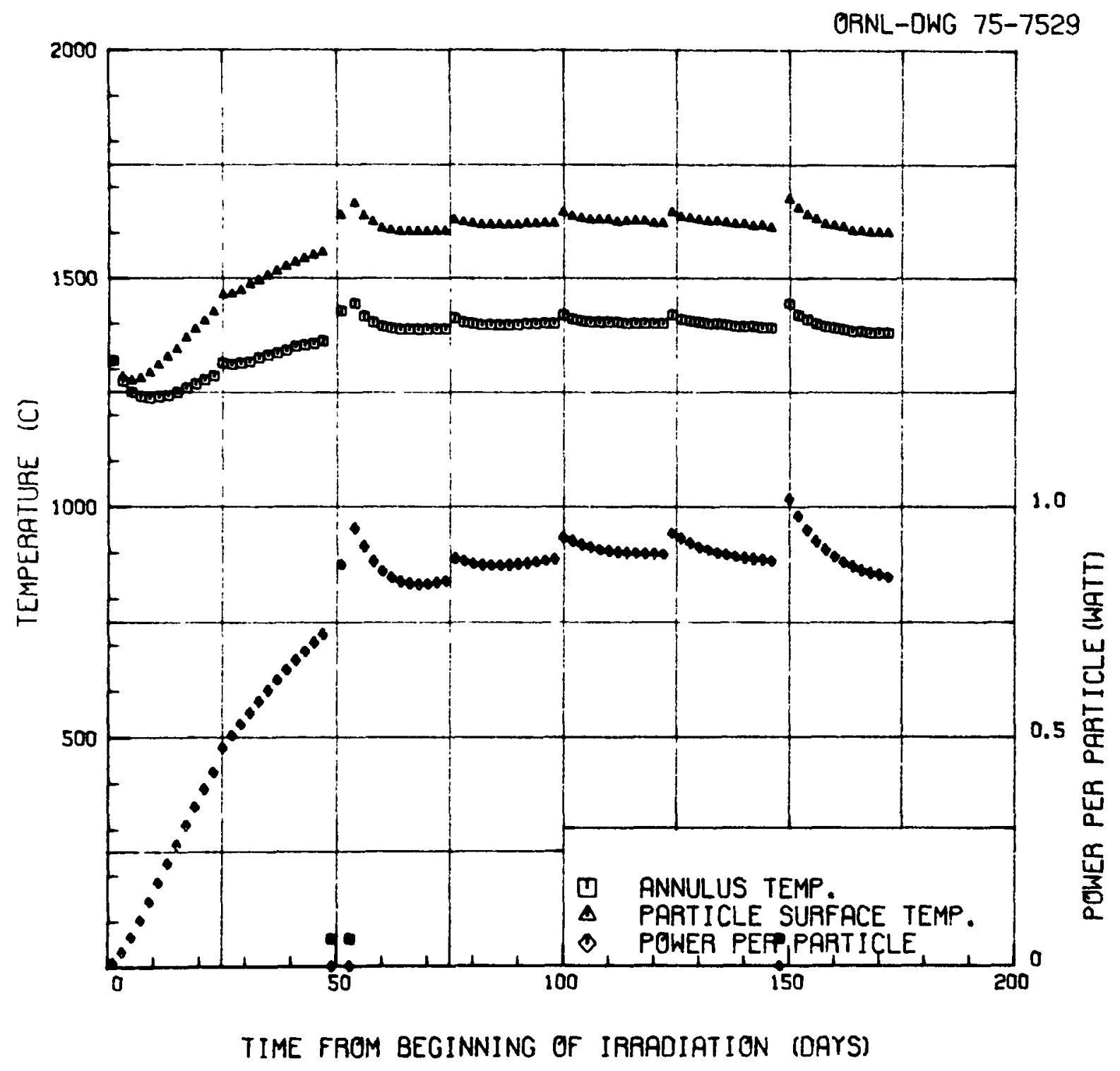

HT-14\&15 PARTICLE HOLDER 23 BATCH GA-4252-06
822.0 MICRON PARTICLE DIAMETER 


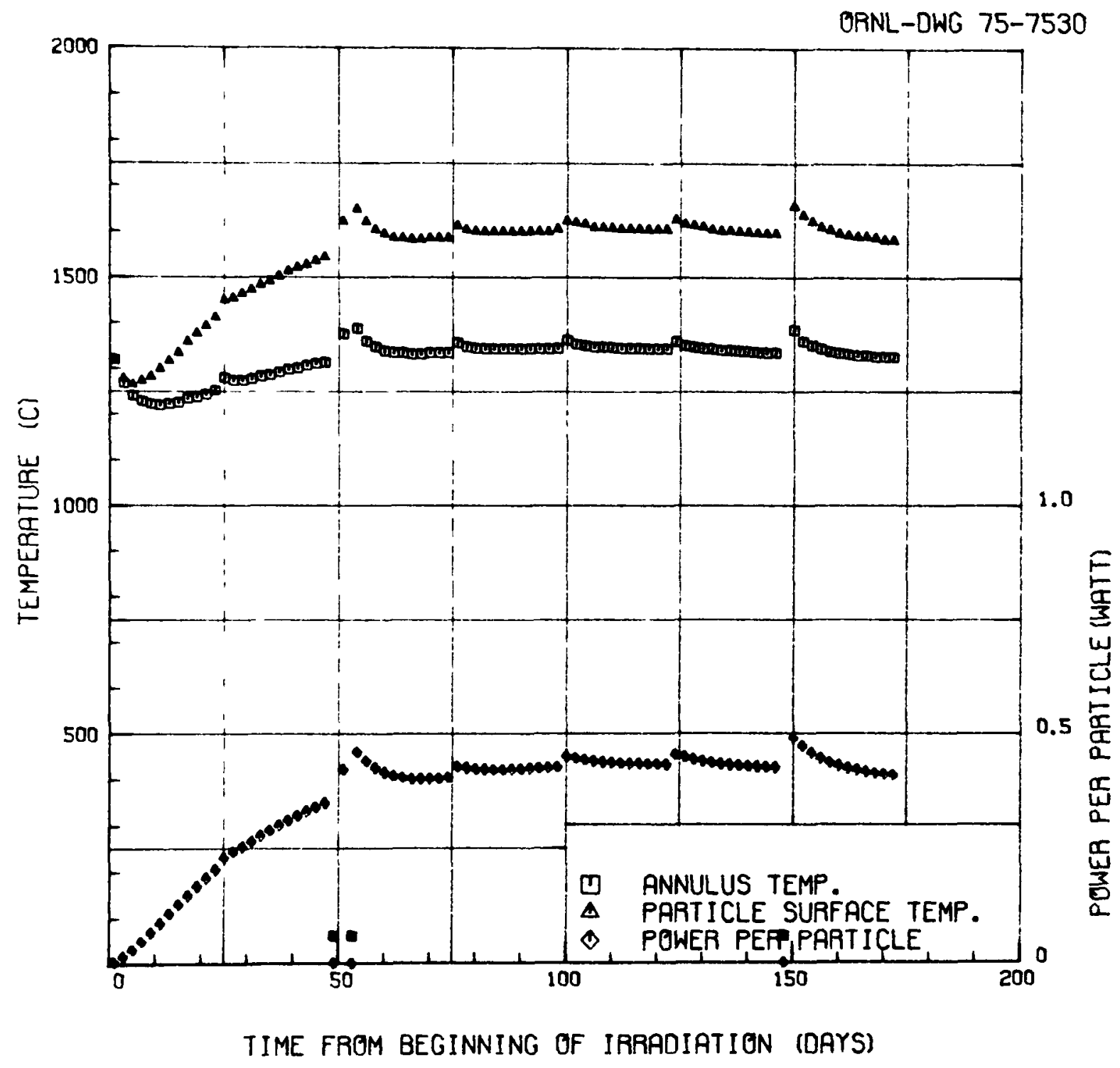

HT-14\&15 PARTICLE HOLDER 24 BATCH OR-1749 540.0 MICRON PARTICLE OIAMETER 


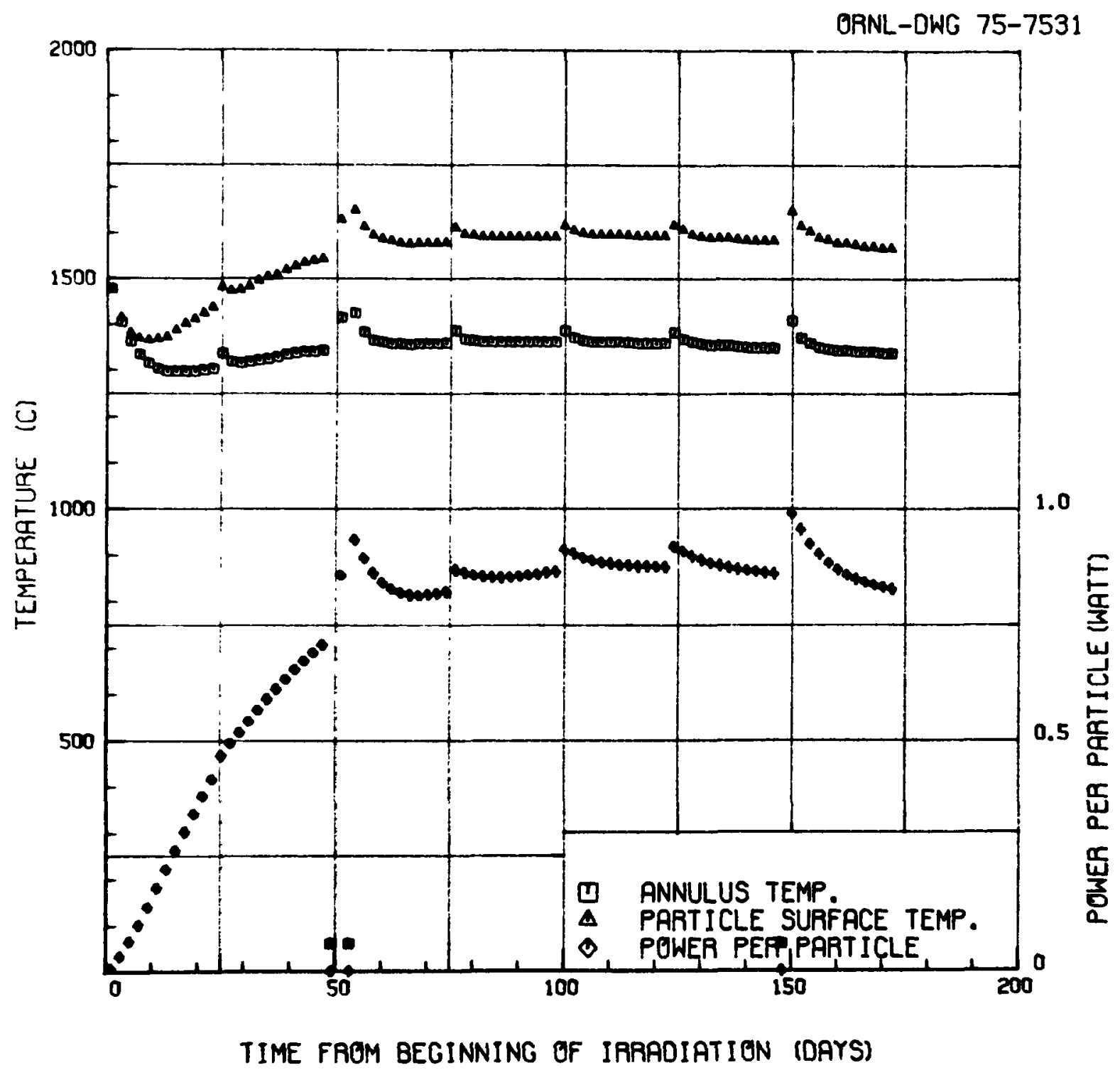

HT-14\&15 PARTICLE HOLOER 26 BATCH OR-1849 816.0 MICRON PARTICLE DIAMETER 


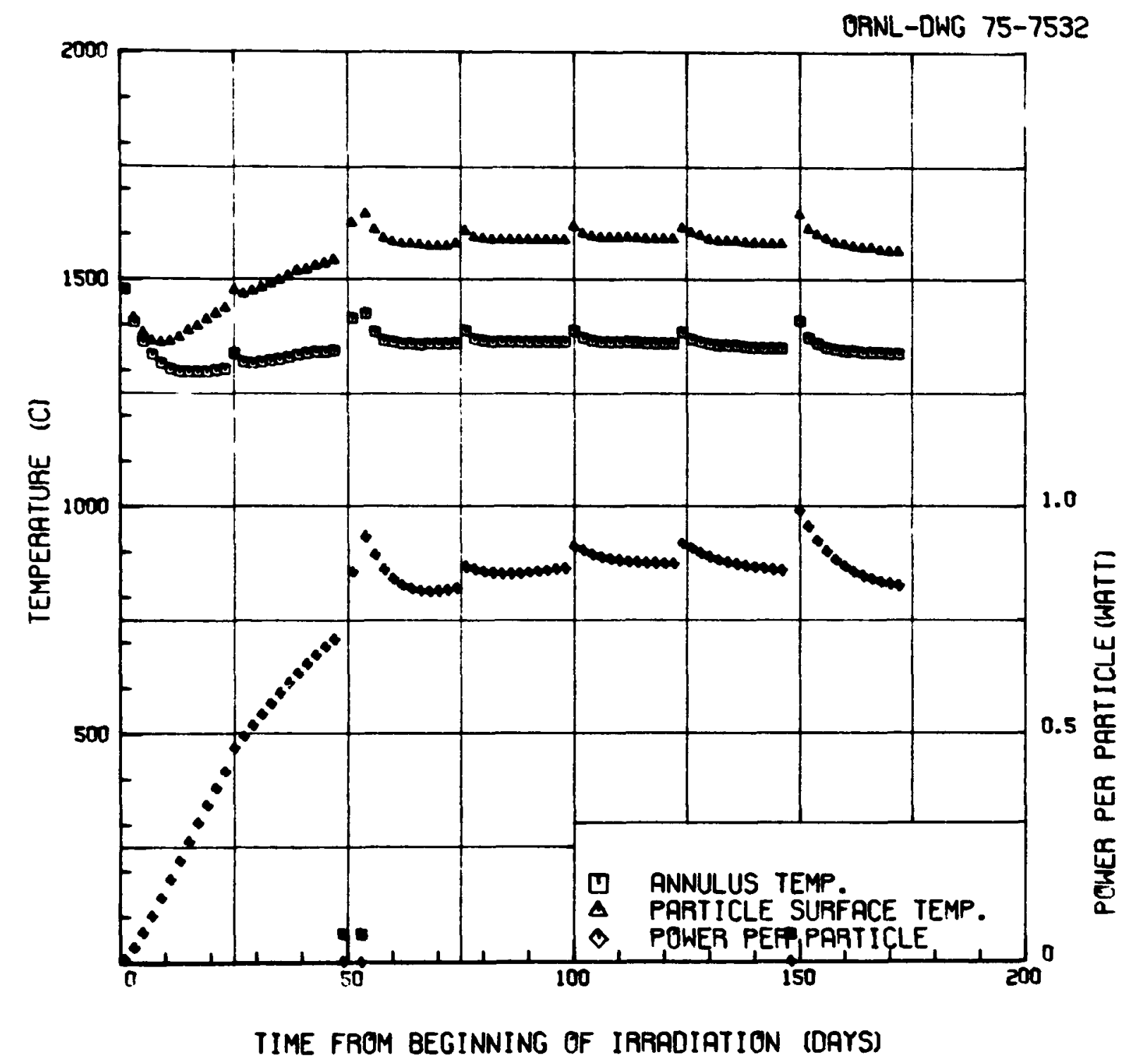

HT-14\&15 PARTICLE HOLDER 27 BATCH GA-4252-02 824. 0 MICRON PARTICLE DIAMETER 


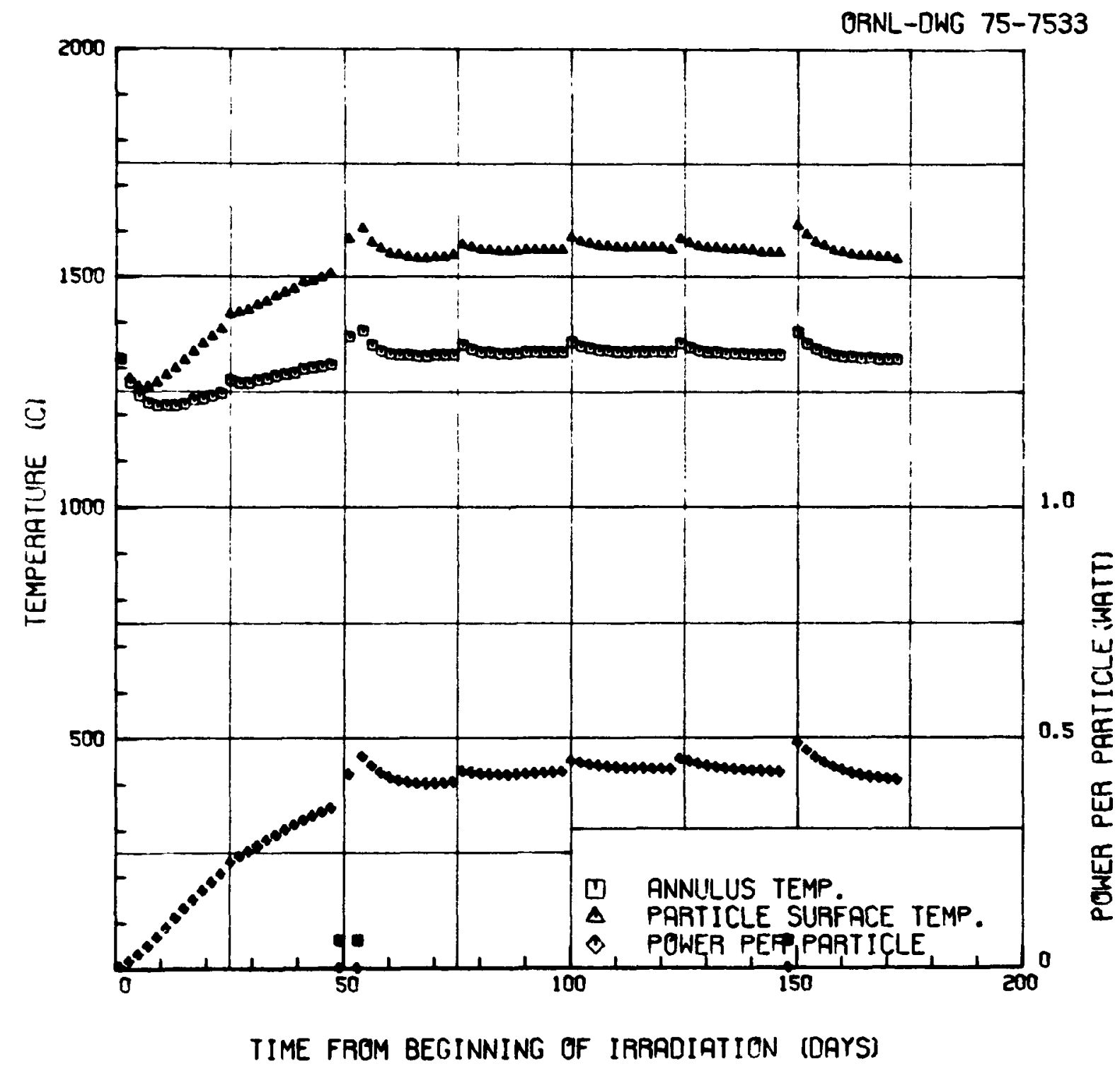

HT-14\&15 PARTICLE HOLDER 29 BATCH OR-1838 594. O MICRON PARTICLE DIAMETER 


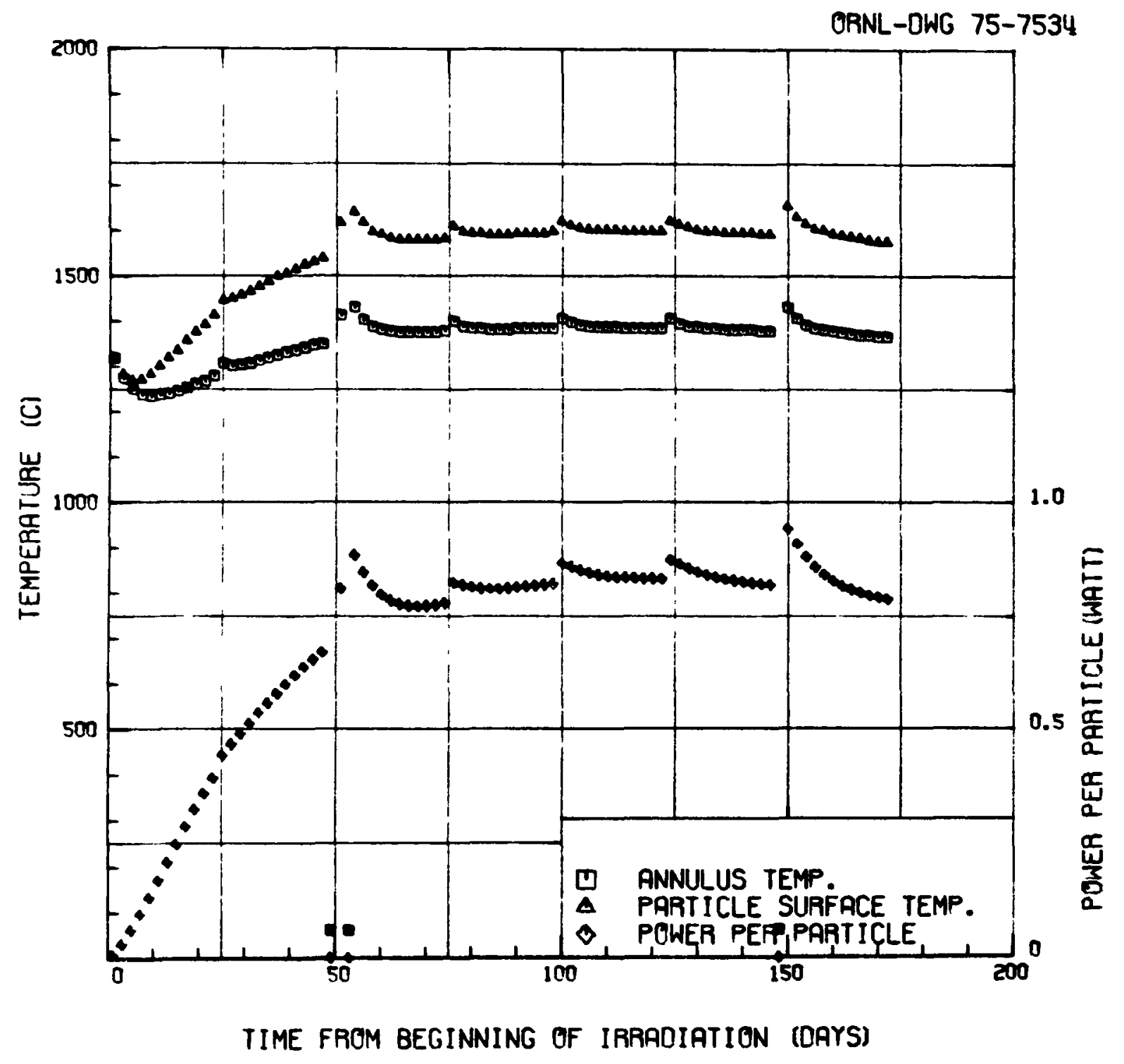

HT-14\&15 PARTICLE HOLDER 30 BATCH GA-4252-03 819.0 MICRON PARTICLE DIAMETER 


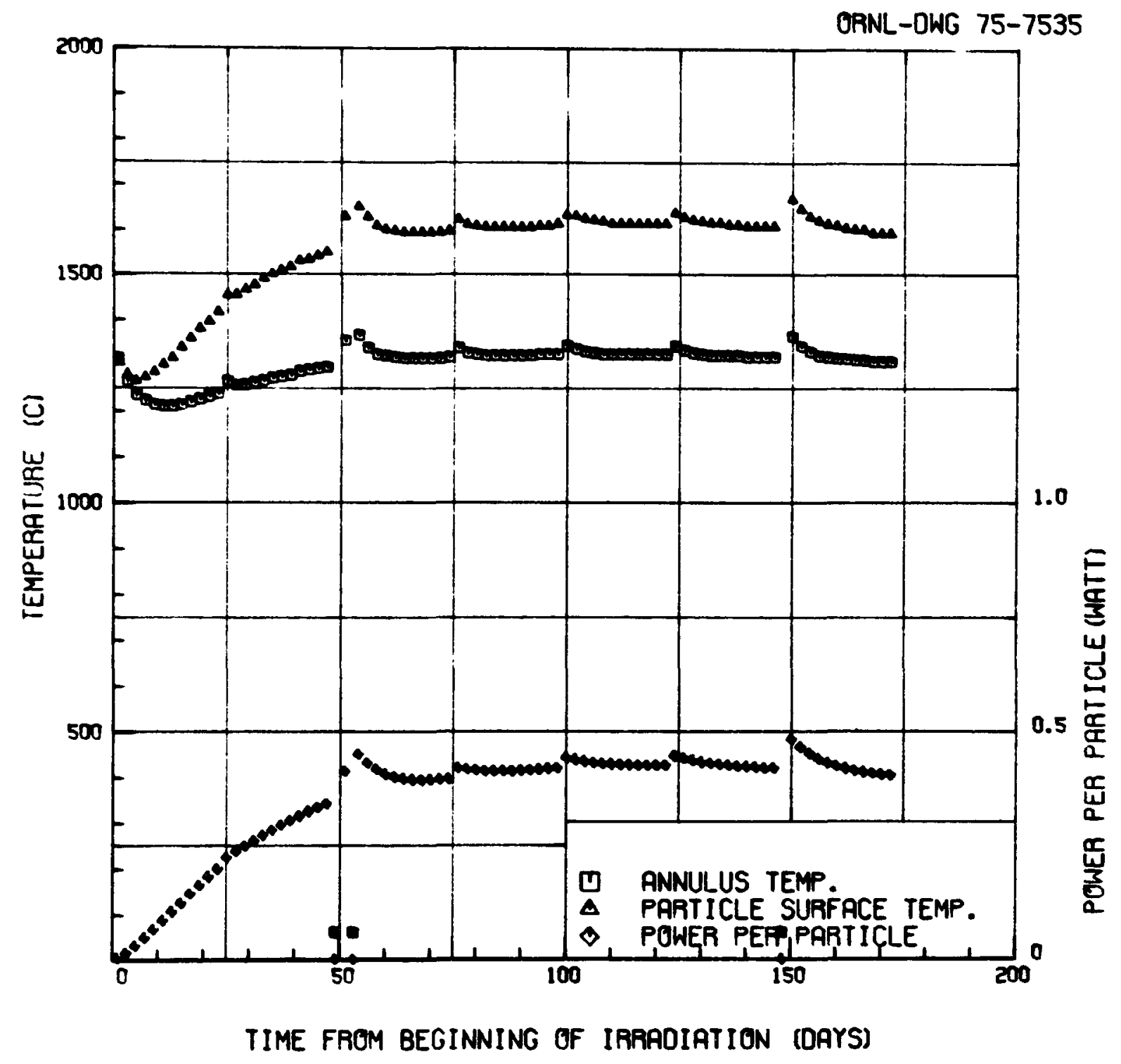

HT-14\&15 PARTICLE HOLDER 32 BATCH OR-1826 506.0 MICRON PARTICLE DIAMETER 


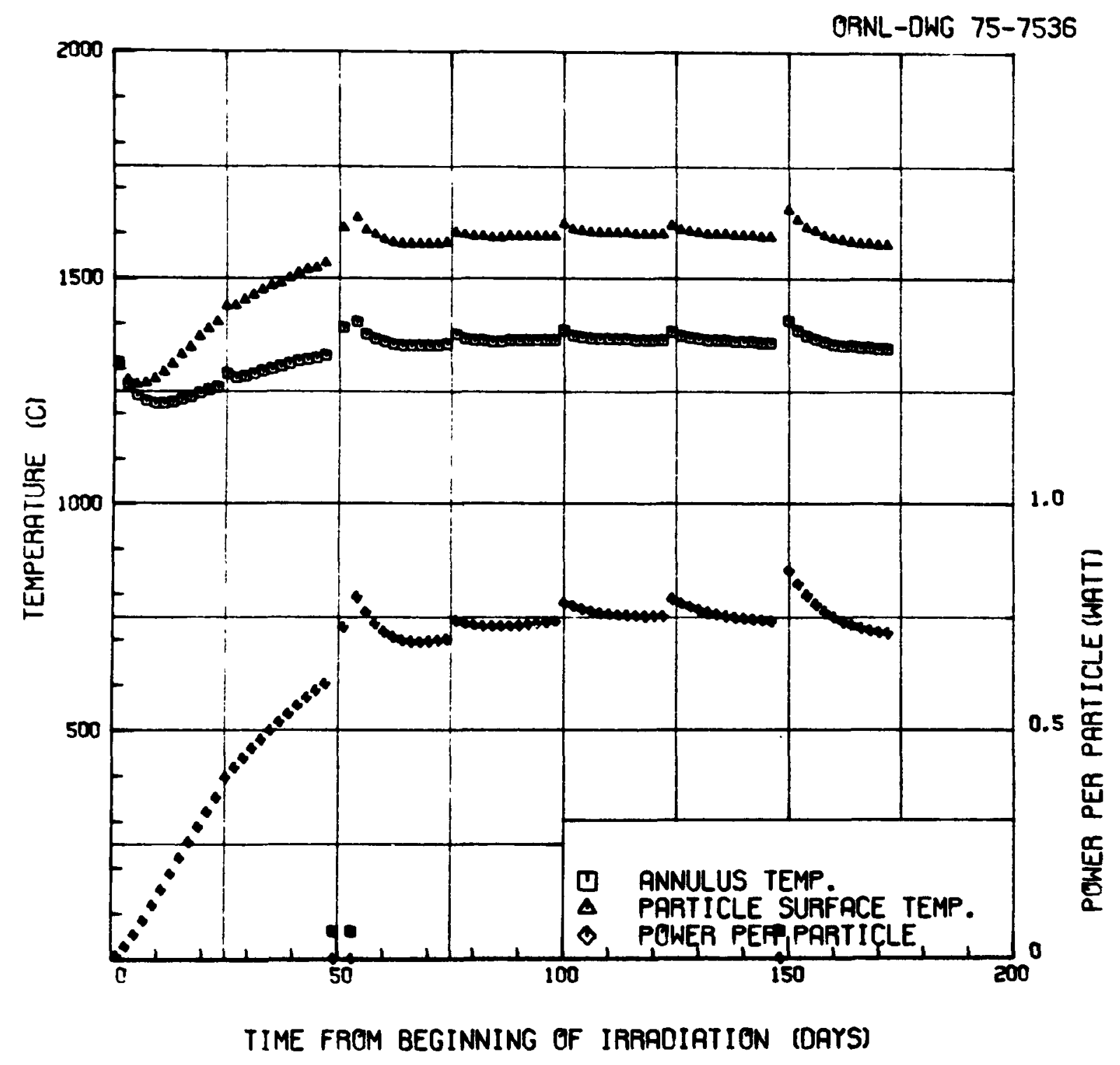

HT-14\&15 PART ICLE HOLDER 33 BATCH GA-4252-01
761.0 MICRON PART ICLE DIAMETER 


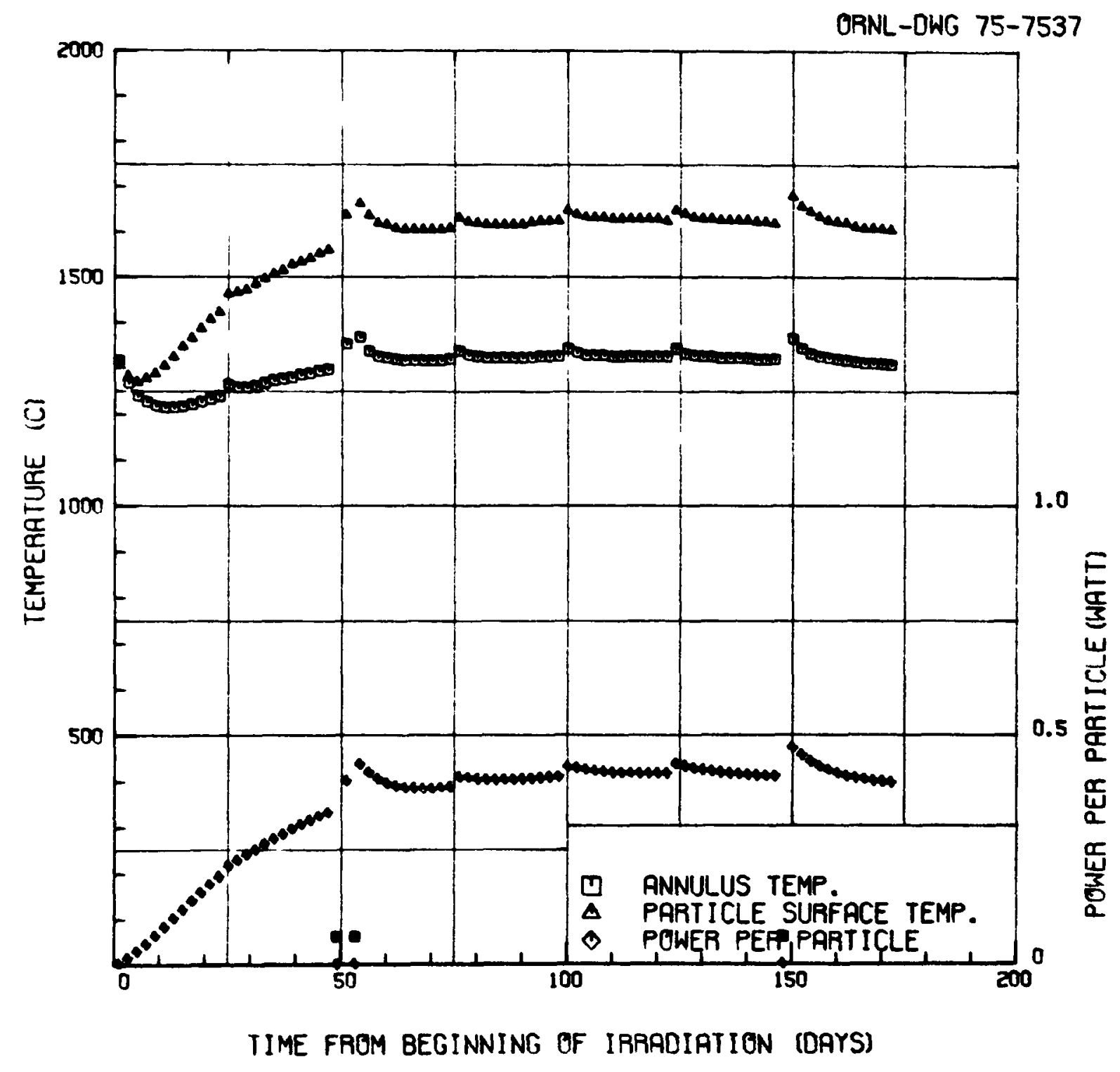
HT-14\&15 PARTICLE HOLDER 35 BATCH OR-1830 480.0 MICRON PARTICLE DIAMETER




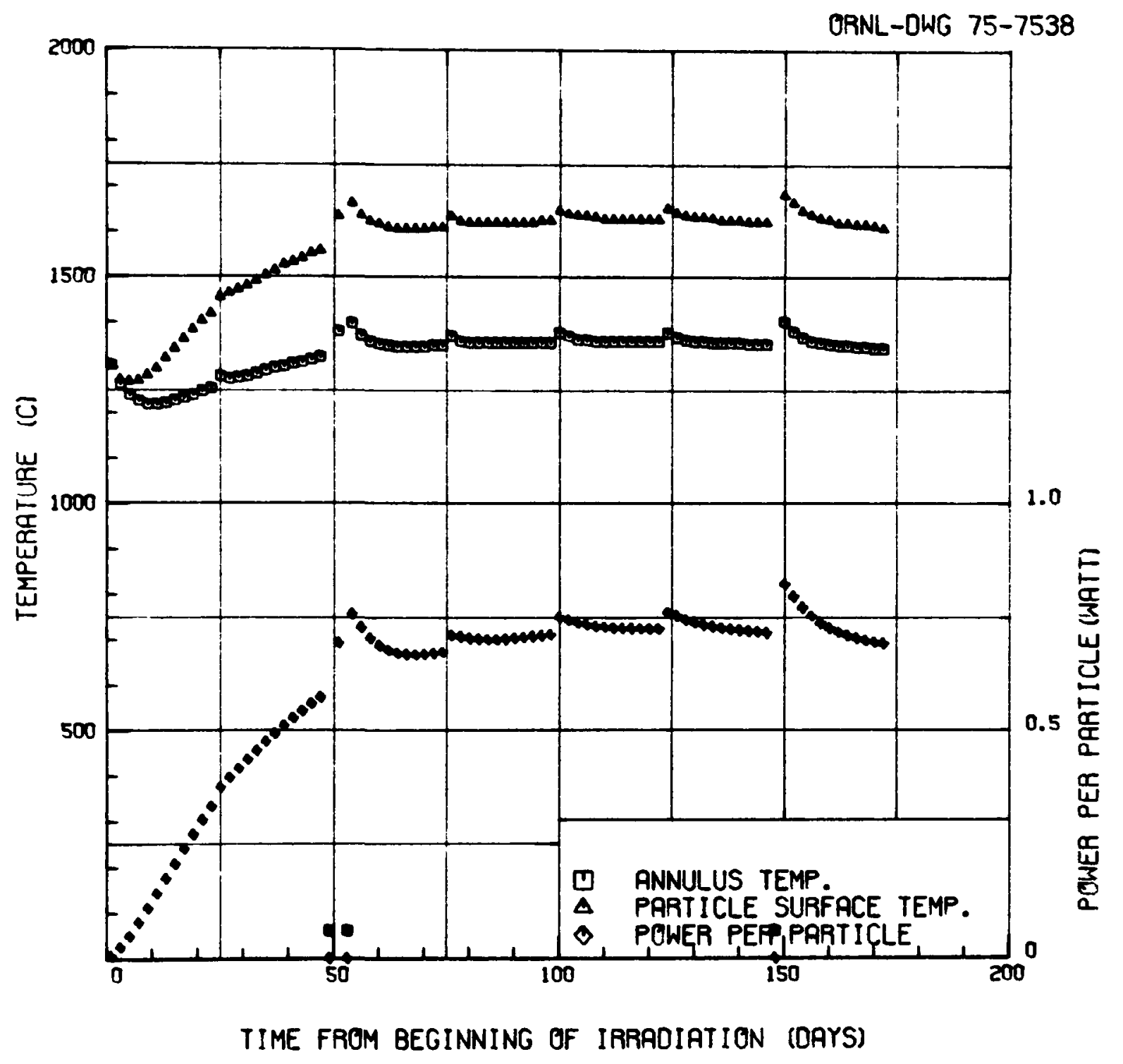

HT-14\&15 PART ICLE HOLDER 36 BATCH GA-4252-07 677.0 MICRON PARTICLE DIAMETER 


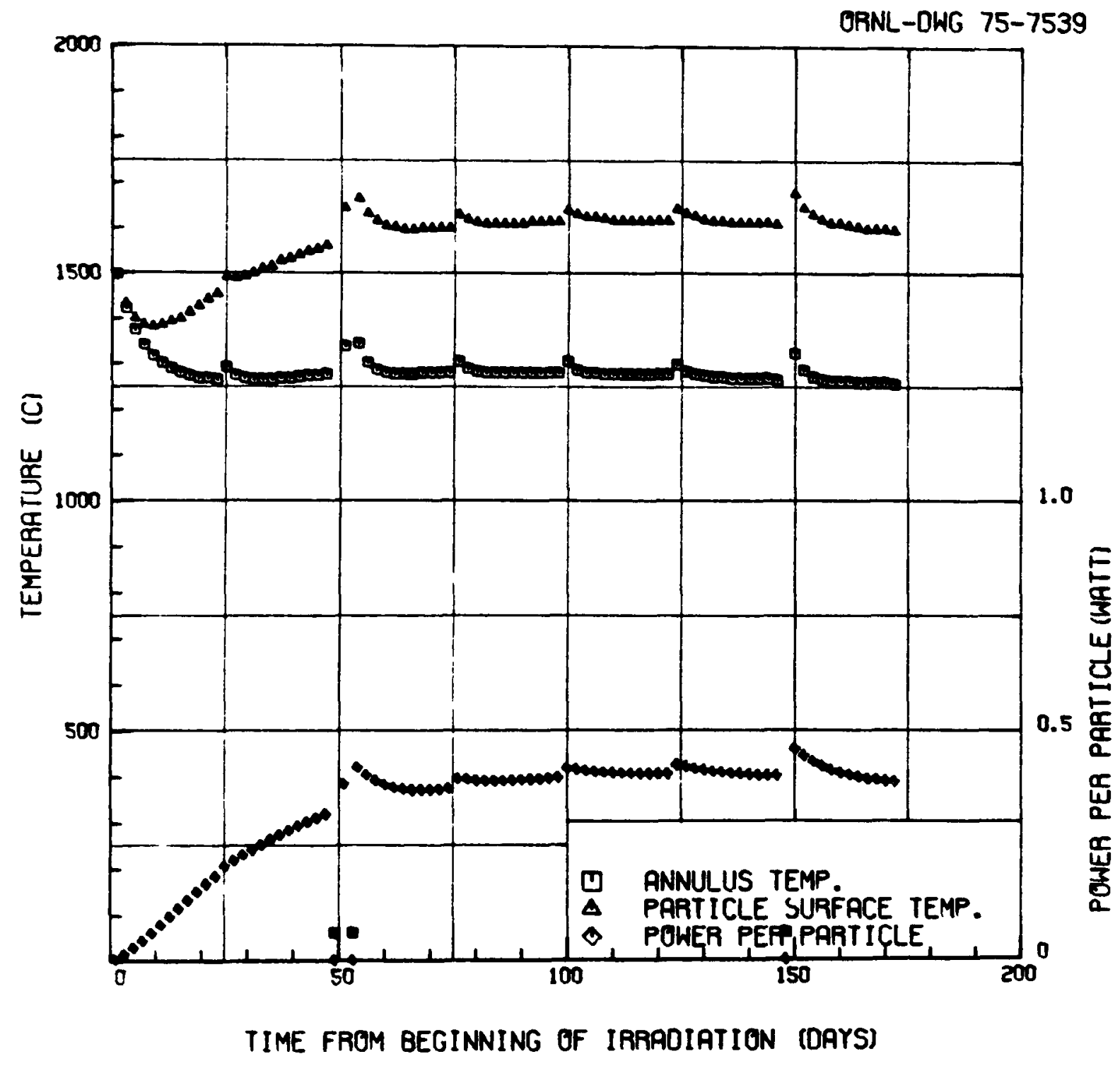

HT-14\&15 PARTICLE HOLDER 38 BATCH OR-1837 452.0 MICRON PARTICLE DIAMETER 


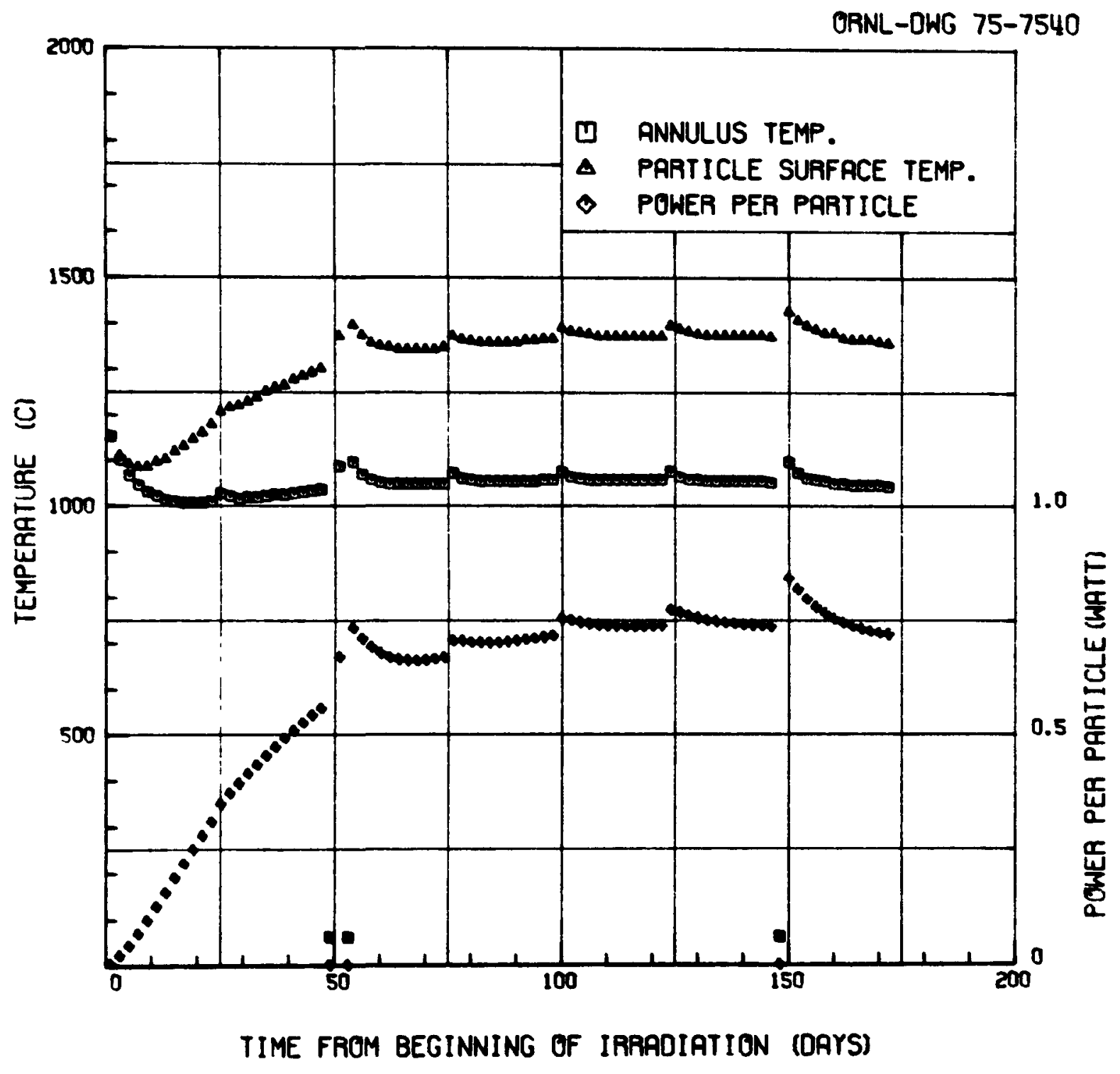

HT-14\&15 PARTICLE HOLDER 40 BATCH GA-4252-02 824. 0 MICRON PART ICLE DIAMETER 


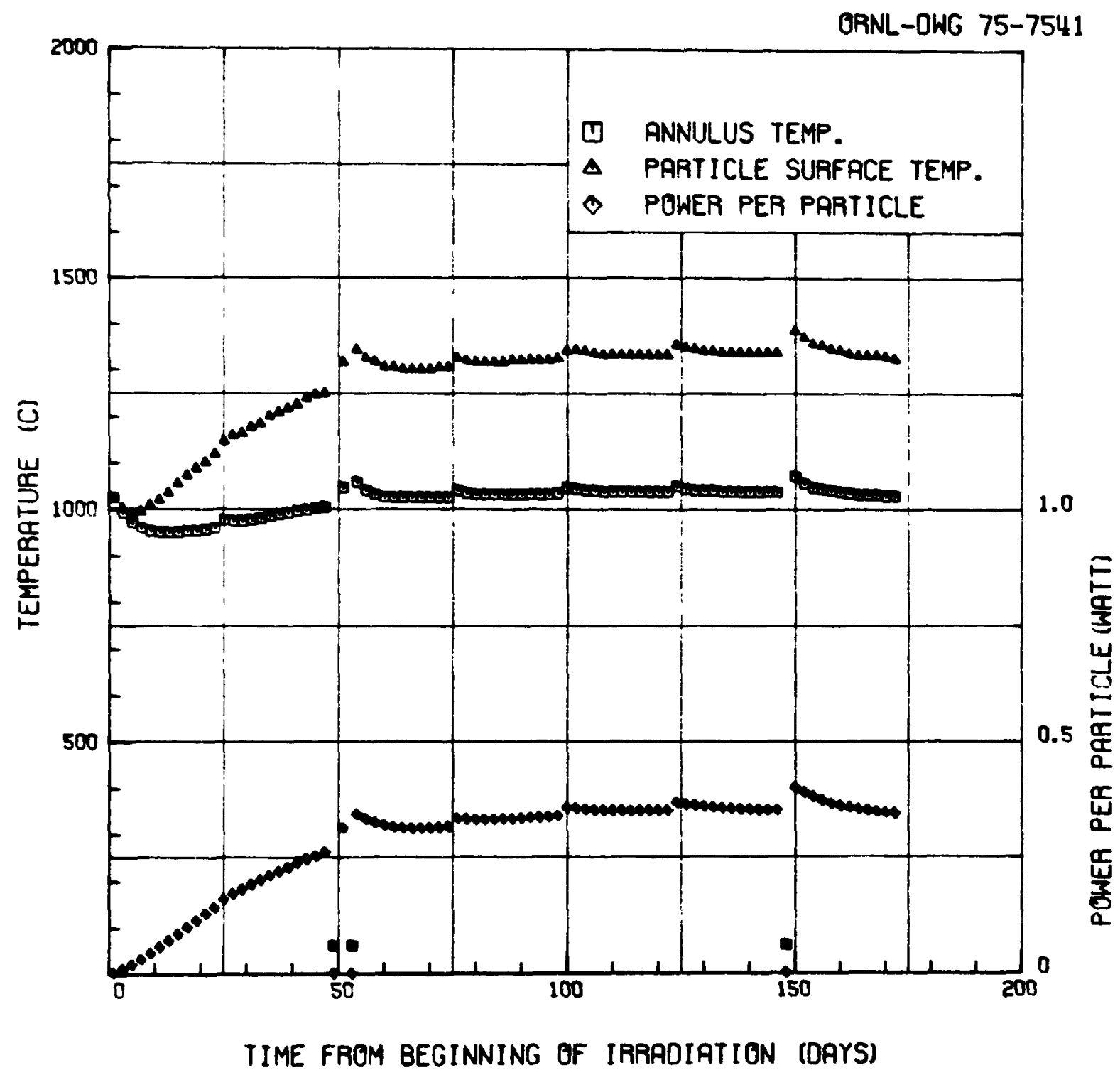

HT-14\$15 PARTICLE HOLDER 42 BATCH OR-1833 594. 0 MICRON PARTICLE DIAMETER 


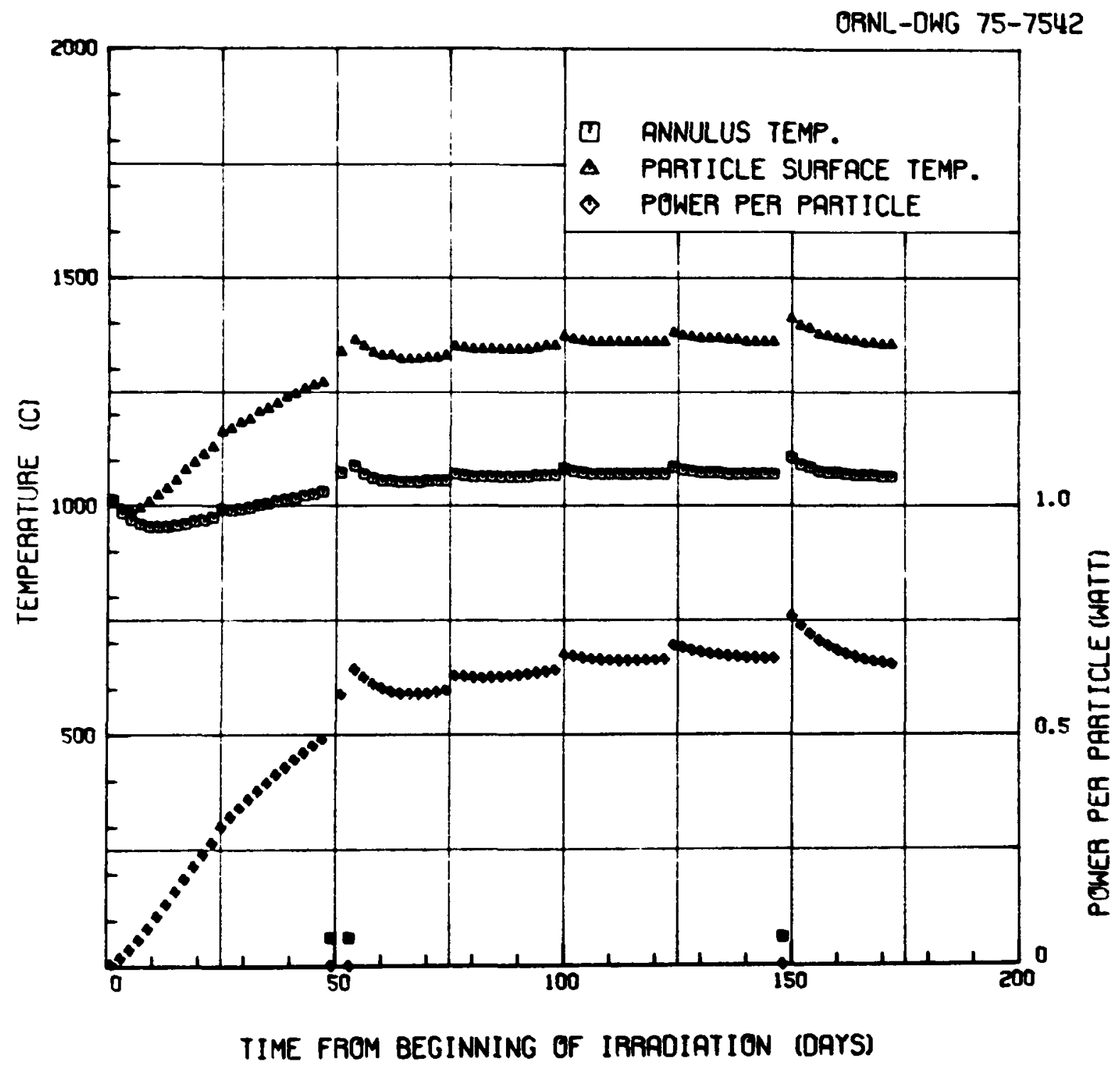

HT-14\&15 PARTICLE HOLDER 43 BATCH GA-4252-03 819.0 MICRON PART ICLE DIAMETER 


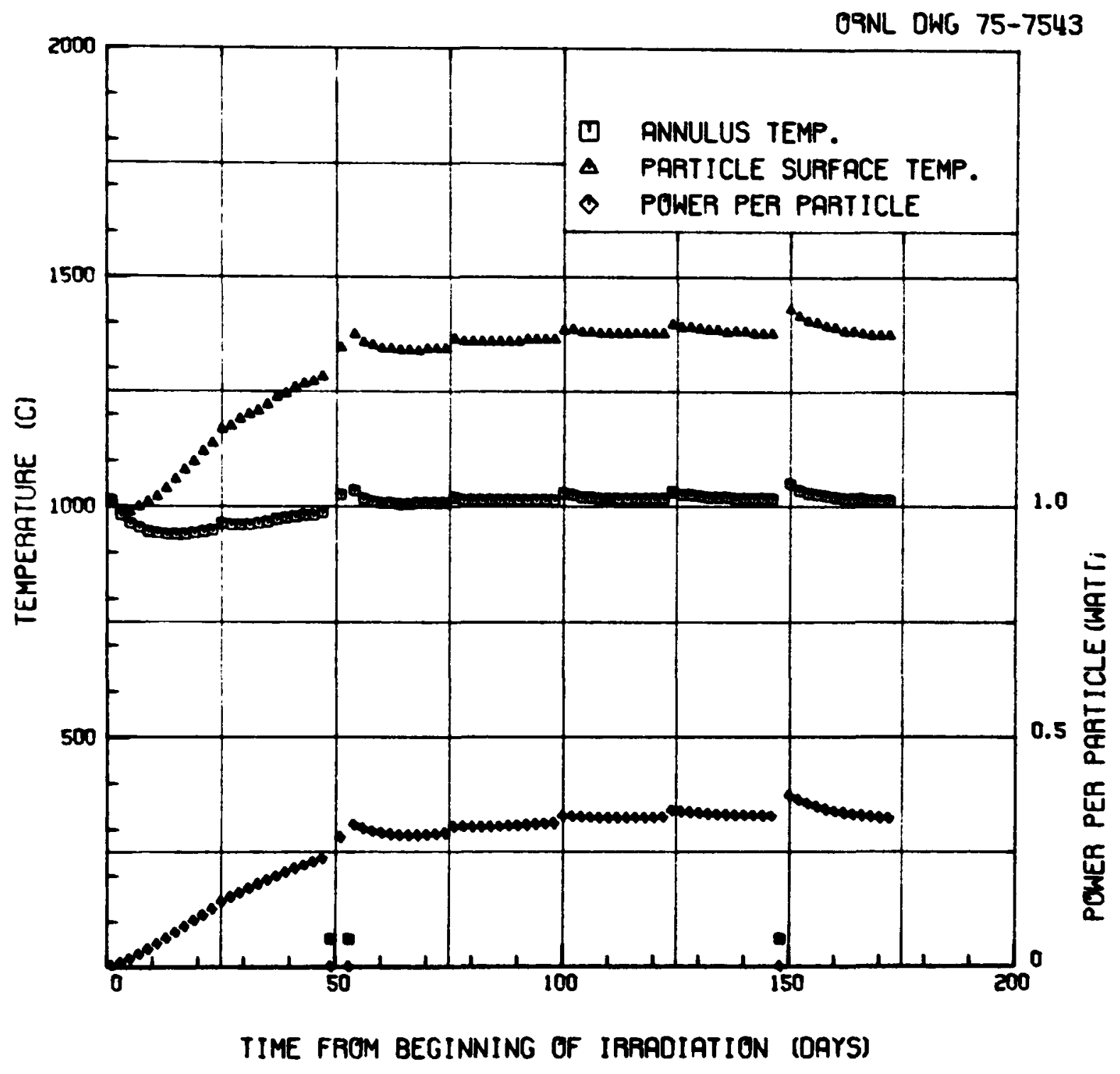

HT-14\&15 PARTICLE HOLDER 45 BATCH OR-1826 506.0 MICRON PARTICLE DIAMETER 


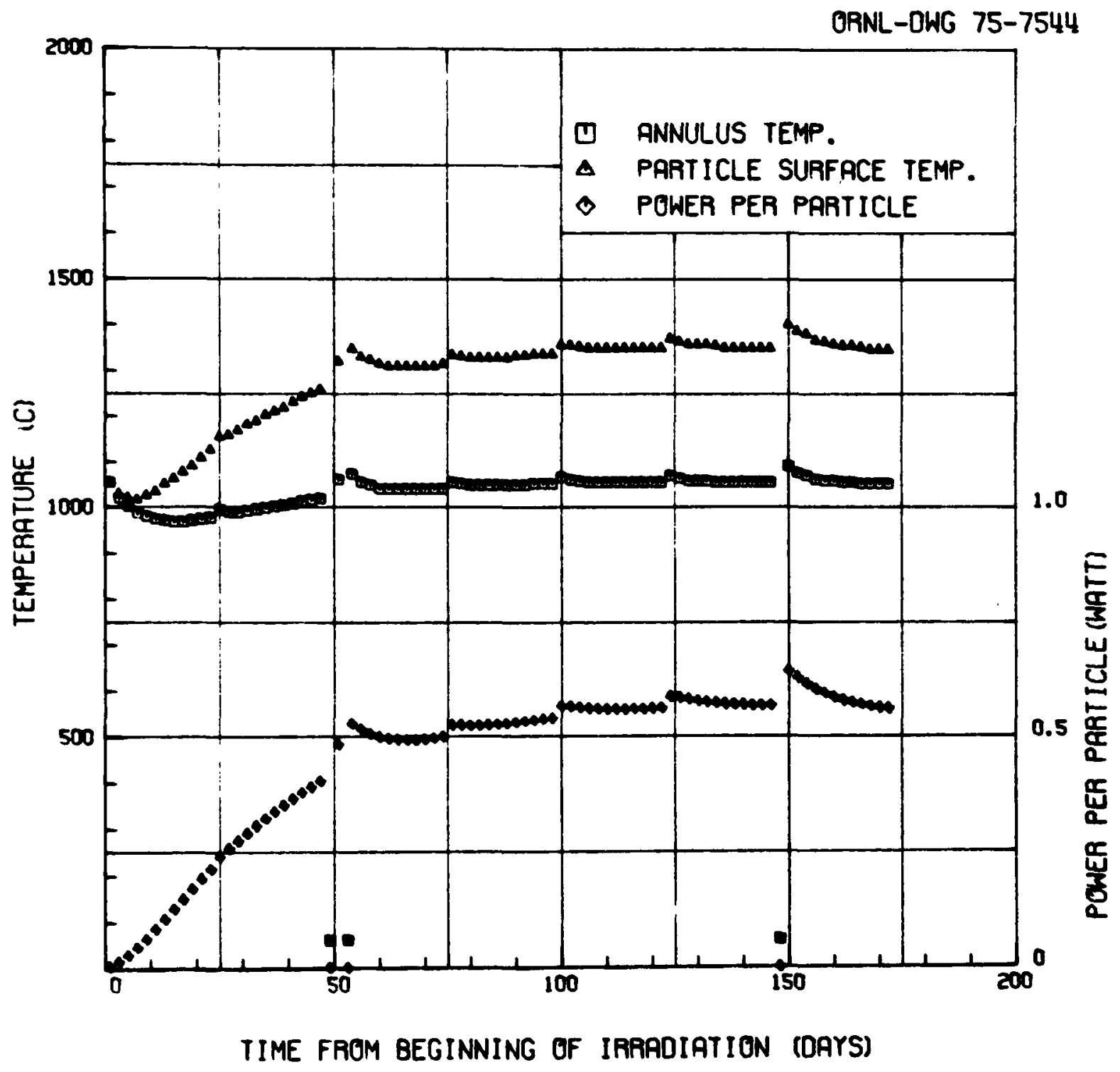

HT-14\&15 PARTICLE HOLDER 46 BATCH GA-4252-01 761.0 MICRON PARTICLE DIAMETER 


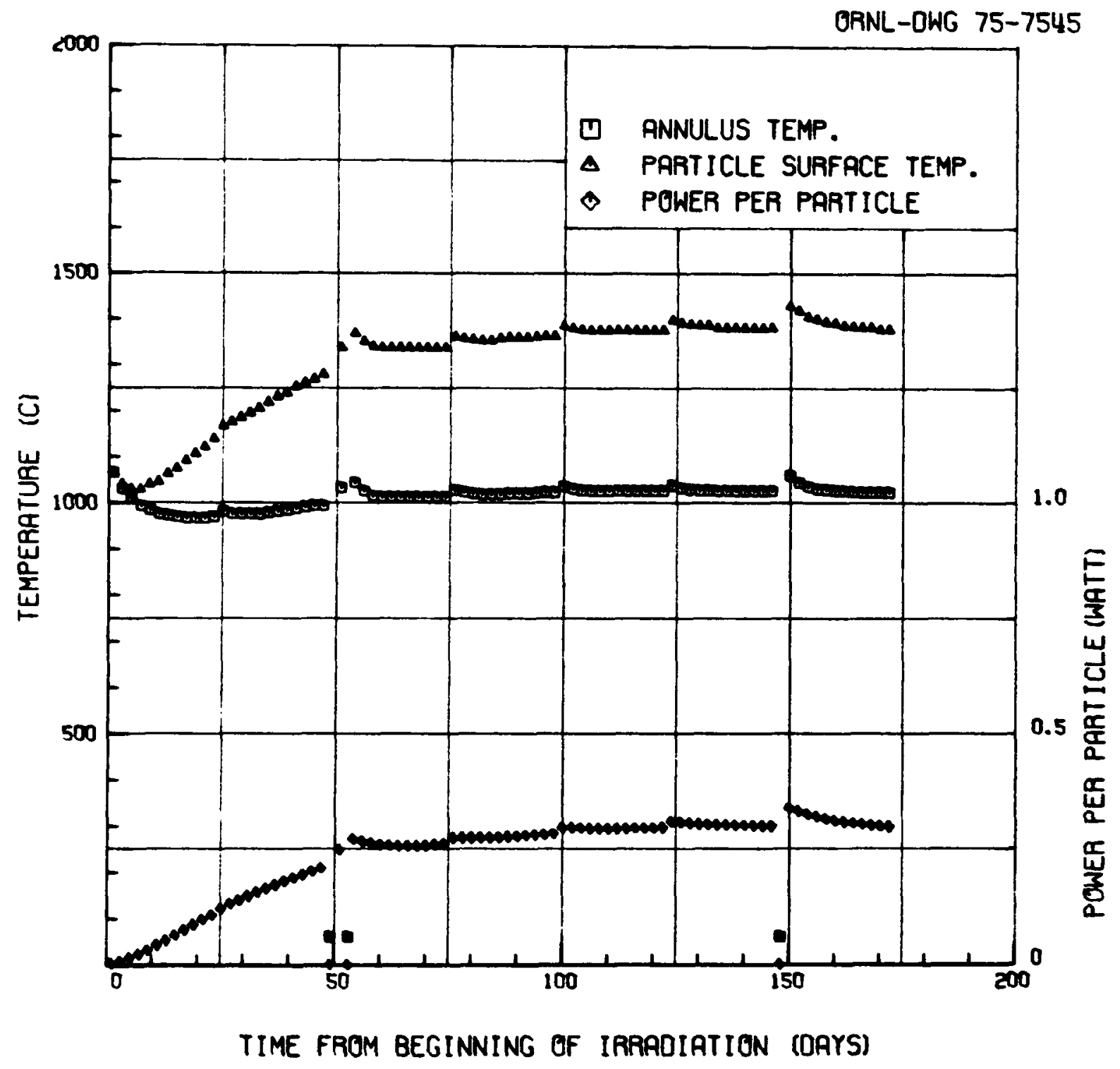

HT-14\&15 PARTICLE HOLDER 48 BATCH OR-1830 480.0 MICRON PRRT ICLE DIAMETER 


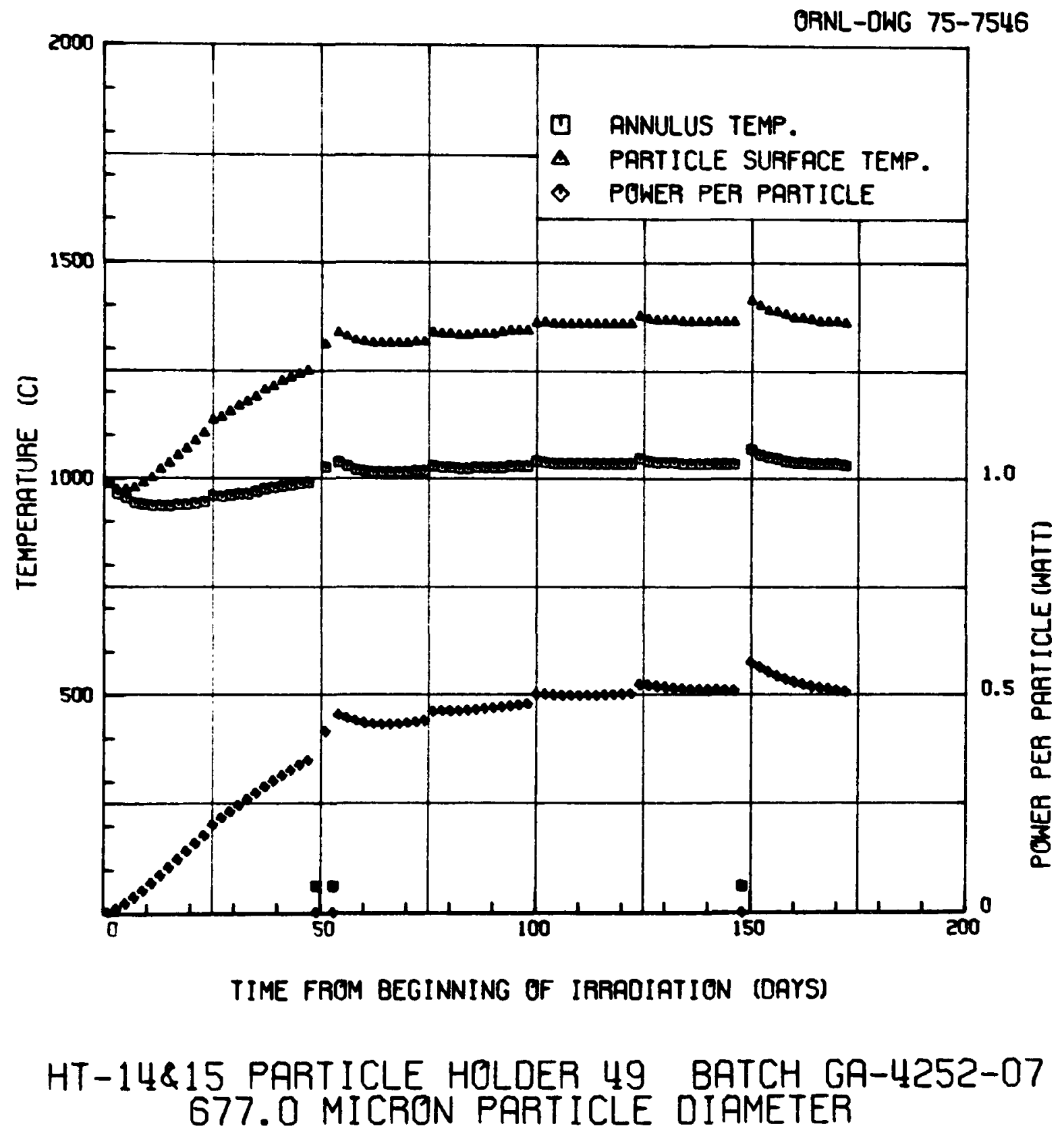




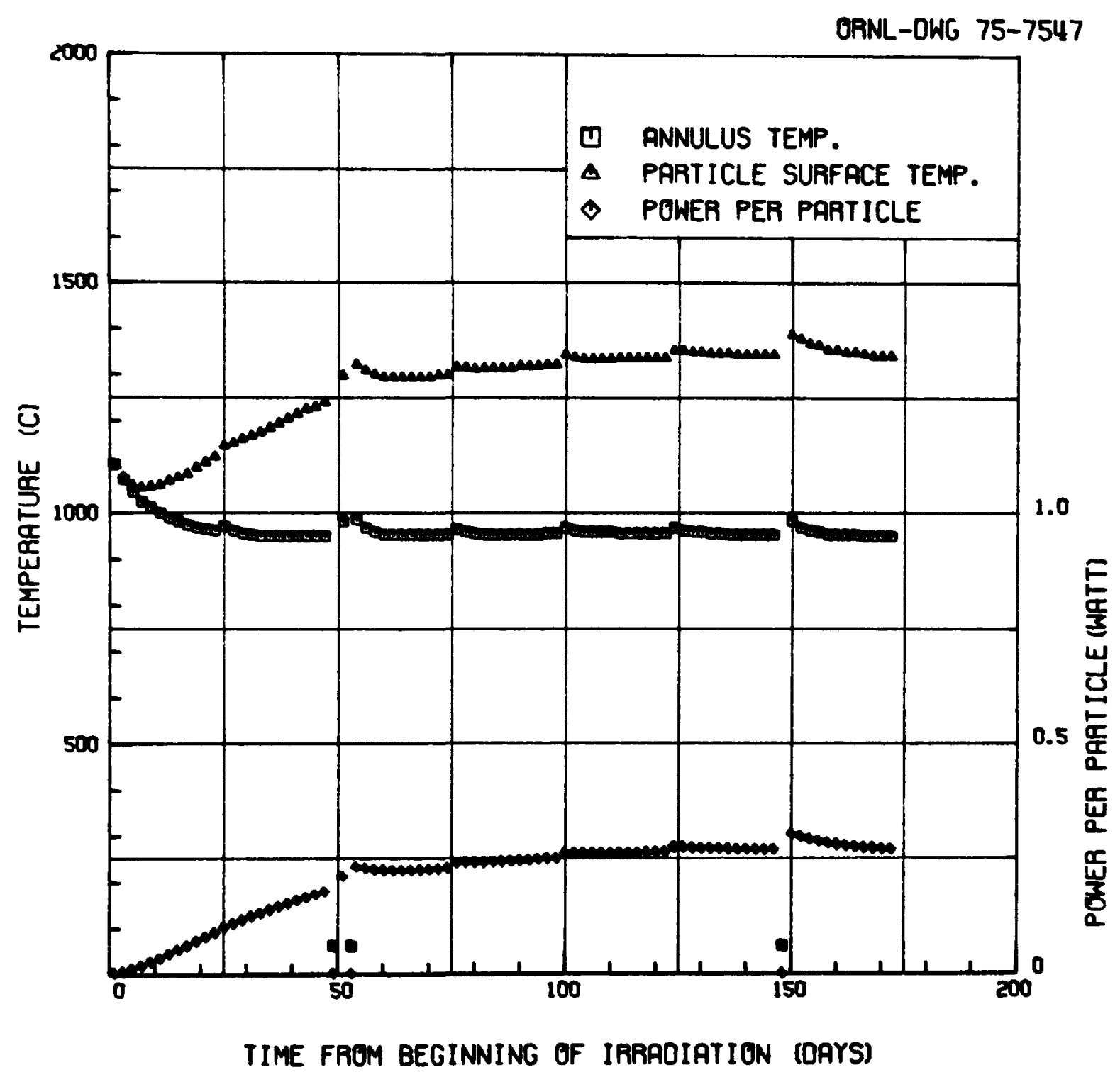

HT-14\&15 PARTICLE HOLDER 51 BATCH OR-1837 452.0 MICRON PARTICLE DIAMETER 


\section{APPENDIX B \\ Measured and Calculated Fission Product Inventories in Biso-Coated $\mathrm{ThO}_{2}$ Particles from Irradiation Capsules HT-12 through HT-15}

Measured fission product inventories at the end of irradiation from gamma-ray analyses are presented in Table B.1. Values are given in atoms of fission products per initial atom of ${ }^{232} \mathrm{Th}$, based on an average of $7.542 \times 10^{17}$ atoms of initial ${ }^{232} \mathrm{Th}$ in particles from batch OR-1838, holder 29, and batch OR-1840, holders 8,21, and 29; and an average of $1.522 \times 10^{18}$ atoms of thorium in particles from batch OR-1849, holders 13 and 26.

Calculated fission product inventories were obtained by an analytical solution of equations for the nuclide chain in Fig. 6.2. Input data are given in Sect. 6. Fission product inventories for the various holders are given in Tables B.2 through B.5. These are based on neutron flux values determined from ${ }^{137} \mathrm{Cs}$ and ${ }^{144} \mathrm{Cs}$ analyses as described in Sect. 9. Burnup values (fraction FIMA) are also presented.

The fission product inventories calculated for various neutron flux levels are given in Tables B.6 through B.9. These tables were used to determine burnups and neutron fluxes from analyzed values of fission products. 
Table B.1. Average inventories of fission products in batches $\mathrm{OR}-1840$ and $\mathrm{OR}-1849$ Biso-coated $\mathrm{ThO}_{2}$ particles from the HT-12 through HT-15 irradiation capsules as determined by gamma-ray analyses

\begin{tabular}{|c|c|c|c|c|c|c|c|c|}
\hline $\begin{array}{c}\text { Sample } \\
\text { No. }{ }^{a}\end{array}$ & $\begin{array}{l}\text { Number of } \\
\text { particles } b\end{array}$ & $\begin{array}{c}\text { Decay }^{c} \\
\text { time }\end{array}$ & & ${ }^{95} \mathrm{Zr}^{d}$ & ${ }^{106} \mathrm{Ru}$ & ${ }^{144} \mathrm{Ce}$ & ${ }^{125} \mathrm{Sb}$ & ${ }^{137} \mathrm{Cs}$ \\
\hline HT-1 2-8 & 16 & $7.15 \mathrm{E} 7$ & $\begin{array}{l}\text { a/a }{ }^{c} \\
\% \text { S.D. } \\
\text { \% error } f\end{array}$ & $\begin{array}{l}3.86 \mathrm{E}-4^{15} \\
8.5 \\
8\end{array}$ & $\begin{array}{l}2.19 \mathrm{E}-5 \\
7.5 \\
5\end{array}$ & $\begin{array}{l}3.79 \mathrm{E}-4 \\
3.9 \\
2.5\end{array}$ & $\begin{array}{l}1.03 \mathrm{E}-5 \\
7.0 \\
5\end{array}$ & $\begin{array}{l}6.46 \mathrm{E}-4 \\
2.8 \\
0.4\end{array}$ \\
\hline HT-1 2-8L & $15 \mathrm{~s}$ & $8.78 \mathrm{E} 7$ & $\begin{array}{l}\text { a/a } \\
\% \text { S.D. } \\
\% \text { error }\end{array}$ & $\begin{array}{l}3.08 \mathrm{E}-4^{10} \\
26 \\
22\end{array}$ & $\begin{array}{l}2.44 \mathrm{E}-5 \\
4.2 \\
3.9\end{array}$ & $\begin{array}{l}3.86 \mathrm{E}-4 \\
2.7 \\
2.2\end{array}$ & $\begin{array}{l}1.06 \mathrm{E}-5 \\
4.1 \\
3.3\end{array}$ & $\begin{array}{l}6.46 \mathrm{E}-4 \\
1.9 \\
0.3\end{array}$ \\
\hline HT-12-13 & 18 & $7.58 \mathrm{E} 7$ & $\begin{array}{l}\text { a/a } \\
\% \text { S.D } \\
\% \text { error }\end{array}$ & $\begin{array}{l}4.88 \mathrm{E}-4^{4} \\
4.8 \\
11\end{array}$ & $\begin{array}{l}2.67 \mathrm{E}-4 \\
6.9 \\
5\end{array}$ & $\begin{array}{l}4.56 \mathrm{E}-4 \\
4.9 \\
2.5\end{array}$ & $\begin{array}{l}1.22 \mathrm{E}-5 \\
6.5 \\
5\end{array}$ & $\begin{array}{l}7.76 \mathrm{E}-4 \\
2.5 \\
0.4\end{array}$ \\
\hline HT-12-13L & $16 s$ & $8.78 \mathrm{E} 7$ & $\begin{array}{l}\text { a/a } \\
\% \text { S.D. } \\
\% \text { error }\end{array}$ & $\begin{array}{l}3.95 \mathrm{E}-4 \\
23 \\
16\end{array}$ & $\begin{array}{l}2.93 \mathrm{E}-5 \\
3.4 \\
3\end{array}$ & $\begin{array}{l}4.75 \mathrm{E}-4 \\
1.8 \\
1.4\end{array}$ & $\begin{array}{l}1.27 \mathrm{E}-5 \\
4.0 \\
2.5\end{array}$ & $\begin{array}{l}7.88 \mathrm{E}-4 \\
1.5 \\
0.2\end{array}$ \\
\hline HT-12-21 & 17 & $7.81 \mathrm{E} 7$ & $\begin{array}{l}\text { a/a } \\
\% \text { S.D. } \\
\% \text { error }\end{array}$ & $\begin{array}{l}6.21 \mathrm{E}-4 \\
9.8 \\
11\end{array}$ & $\begin{array}{l}4.15 E-5 \\
3.3 \\
3\end{array}$ & $\begin{array}{l}6.64 \mathrm{E}-4 \\
2.7 \\
1.6\end{array}$ & $\begin{array}{l}1.73 \mathrm{E}-5 \\
4.9 \\
3\end{array}$ & $\begin{array}{l}1.10 \mathrm{E}-3 \\
2.7 \\
0.2\end{array}$ \\
\hline HT-12-21L & $16 s$ & $9.03 \mathrm{E} 7$ & $\begin{array}{l}\text { a/a } \\
\% \text { S.D. } \\
\% \text { error }\end{array}$ & & $\begin{array}{l}3.96 \mathrm{E}-5 \\
4.1 \\
3.1\end{array}$ & $\begin{array}{l}6.44 \mathrm{E}-4 \\
3.9 \\
1.6\end{array}$ & $\begin{array}{l}1.69 \mathrm{E}-5 \\
3.9 \\
2.4\end{array}$ & $\begin{array}{l}1.09 \mathrm{E}-3 \\
2.0 \\
0.2\end{array}$ \\
\hline HT-12-26 & 15 & $7.86 \mathrm{E} 7$ & $\begin{array}{l}\text { a/a } \\
\% \text { S.D. } \\
\% \text { error }\end{array}$ & $\begin{array}{l}6.96 \mathrm{E}-4 \\
11 \\
7\end{array}$ & $\begin{array}{l}4.17 \mathrm{E}-5 \\
4.1 \\
2.4\end{array}$ & $\begin{array}{l}6.85 \mathrm{E}-4 \\
2.0 \\
1.2\end{array}$ & $\begin{array}{l}1.77 \mathrm{E}-5 \\
2.9 \\
2.1\end{array}$ & $\begin{array}{l}1.13 \mathrm{E}-3 \\
2.4 \\
0.1\end{array}$ \\
\hline HT-12-26 & $1 \mathrm{f}$ & $7.86 \mathrm{E} 7$ & $a / a$ & $6.31 \mathrm{E}-4$ & $3.93 \mathrm{E}-5$ & $6.34 \mathrm{E}-4$ & $1.75 \mathrm{E}-5$ & $1.10 \mathrm{E}-3$ \\
\hline HT-12-26L & $15 \mathrm{~s}$ & $9.12 \mathrm{E} 7$ & $\begin{array}{l}\text { a/a } \\
\% \text { S.D. } \\
\text { \% error }\end{array}$ & $5.92 \mathrm{E}-4^{2}$ & $\begin{array}{l}4.11 \mathrm{E}-5 \\
4.8 \\
2.7\end{array}$ & $\begin{array}{l}6.75 \mathrm{E}-4 \\
3.5 \\
1.4\end{array}$ & $\begin{array}{l}1.75 \mathrm{E}-5 \\
3.5 \\
2.1\end{array}$ & $\begin{array}{l}1.10 \mathrm{E}-3 \\
2.0 \\
0.2\end{array}$ \\
\hline HT-13-8 & 18 & $6.89 \mathrm{E} 7$ & $\begin{array}{l}\text { a/a } \\
\% \text { S.D. } \\
\% \text { error }\end{array}$ & $\begin{array}{l}1.43 \mathrm{E}-3 \\
8.1 \\
7\end{array}$ & $\begin{array}{l}1.44 \mathrm{E}-4 \\
5.1 \\
4\end{array}$ & $\begin{array}{l}1.61 \mathrm{E}-3 \\
3.5 \\
1.9\end{array}$ & $\begin{array}{l}4.04 \mathrm{E}-5 \\
4.9 \\
4\end{array}$ & $\begin{array}{l}2.87 \mathrm{E}-3 \\
2.3 \\
0.3\end{array}$ \\
\hline HT-13-8L & $15 \mathrm{~s}$ & $7.88 \mathrm{E} 7$ & $\begin{array}{l}\text { a/a } \\
\% \text { S.D. } \\
\% \text { error }\end{array}$ & $\begin{array}{l}1.43 \mathrm{E}-3 \\
19.1 \\
12\end{array}$ & $\begin{array}{l}1.11 \mathrm{E}-4 \\
8.0 \\
2\end{array}$ & $\begin{array}{l}1.70 \mathrm{E}-3 \\
3.6 \\
1.6\end{array}$ & $\begin{array}{l}4.30 \mathrm{E}-5 \\
4.5 \\
3\end{array}$ & $\begin{array}{l}2.97 \\
2.9\end{array}$ \\
\hline HT-13-8 & $1 \mathrm{f}$ & $6.89 \mathrm{E} 7$ & $a / a$ & $1.63 \mathrm{E}-3$ & $1.02 \mathrm{E}-4$ & $1.65 \mathrm{E}-3$ & $4.13 E-5$ & $2.88 \mathrm{E}-3$ \\
\hline HT-13-13 & 15 & $6.96 \mathrm{E} 7$ & $\begin{array}{l}\text { a/a } \\
\% \text { S.D. } \\
\% \text { error }\end{array}$ & $\begin{array}{l}1.71 \mathrm{E}-3 \\
7.8 \\
5\end{array}$ & $\begin{array}{l}1.24 \mathrm{E}-4 \\
4.3 \\
3\end{array}$ & $\begin{array}{l}1.93 \mathrm{E}-3 \\
3.5 \\
1.4\end{array}$ & $\begin{array}{l}4.52 \mathrm{E}-5 \\
4.3 \\
3.1\end{array}$ & $\begin{array}{l}3.43 \\
2.0 \\
0.2\end{array}$ \\
\hline HT-13-13L & $12 \mathrm{~s}$ & $8.10 \mathrm{E} 7$ & $\begin{array}{l}\text { a/a } \\
\% \text { S.D. } \\
\% \text { error }\end{array}$ & $\begin{array}{l}1.75 \mathrm{E}-3 \\
13.7 \\
10\end{array}$ & $\begin{array}{l}1.34 \\
4.8 \\
2\end{array}$ & $\begin{array}{l}2.04 \mathrm{E}-3 \\
1.6 \\
1.2\end{array}$ & $\begin{array}{l}4.80 E-5 \\
4.2 \\
2\end{array}$ & $\begin{array}{l}3.56 \mathrm{E}-3 \\
1.4 \\
0.2\end{array}$ \\
\hline HT-13-21 & 18 & $6.10 \mathrm{E} 7$ & $\begin{array}{l}\text { a/a } \\
\% \text { S.D. } \\
\% \text { error }\end{array}$ & $\begin{array}{l}2.50 \mathrm{E}-3 \\
4.9 \\
2.0\end{array}$ & $\begin{array}{l}1.68 \mathrm{E}-4 \\
3.6 \\
2\end{array}$ & $\begin{array}{l}2.65 \mathrm{E}-3 \\
2.4 \\
1.0\end{array}$ & $\begin{array}{l}2.54 \mathrm{E}-5 \\
8.4 \\
2.8\end{array}$ & $\begin{array}{l}3.58 \mathrm{E}-3 \\
8.6 \\
0.2\end{array}$ \\
\hline HT-13-26 & 19 & $7.08 \mathrm{E} 7$ & $\begin{array}{l}\text { a/a } \\
\% \text { S.D. } \\
\% \text { error }\end{array}$ & $\begin{array}{l}2.43 \mathrm{E}-3 \\
7.3 \\
4.6\end{array}$ & $\begin{array}{l}1.79 \mathrm{E}-4 \\
3.9 \\
2.3\end{array}$ & $\begin{array}{l}2.73 \mathrm{E}-3 \\
2.0 \\
1.1\end{array}$ & $\begin{array}{l}5.9 \mathrm{E}-5 \\
3.7 \\
2.6\end{array}$ & $\begin{array}{l}3.62 \mathrm{E}-3 \\
12.1 \\
0.2\end{array}$ \\
\hline HT-13-26L & $16 \mathrm{~s}$ & $8.89 \mathrm{E} 7$ & $\begin{array}{l}\text { a/a } \\
\% \text { S.D. } \\
\% \text { errors }\end{array}$ & $\begin{array}{l}2.17 \mathrm{E}-3^{2} \\
10\end{array}$ & $\begin{array}{l}1.71 \mathrm{E}-4 \\
8.4 \\
2.5\end{array}$ & $\begin{array}{l}2.77 \mathrm{E}-3 \\
5.1 \\
1.3\end{array}$ & $\begin{array}{l}5.75 E-5 \\
7.3 \\
2.4\end{array}$ & $\begin{array}{l}3.76 \mathbf{E}-3 \\
12.2 \\
0.12\end{array}$ \\
\hline HT-13-29 & 18 & $6.35 \mathrm{E} 7$ & $\begin{array}{l}\text { a/a } \\
\% \text { S.D. } \\
\% \text { error }\end{array}$ & $\begin{array}{l}2.62 \mathrm{E}-3 \\
7.0 \\
4\end{array}$ & $\begin{array}{l}1.90 \mathrm{E}-4 \\
7.6 \\
4\end{array}$ & $\begin{array}{l}2.85 E-3 \\
5.1 \\
2\end{array}$ & $\begin{array}{l}6.14 E-5 \\
7.5 \\
5.7\end{array}$ & $\begin{array}{l}4.59 \mathrm{E}-3 \\
3.3 \\
0.4\end{array}$ \\
\hline
\end{tabular}


Table B.1 (continued)

\begin{tabular}{|c|c|c|c|c|c|c|c|c|}
\hline $\begin{array}{c}\text { Sample } \\
\text { No. }{ }^{a}\end{array}$ & $\begin{array}{l}\text { Number of } \\
\text { particles } b\end{array}$ & $\begin{array}{c}\text { Decay }^{c} \\
\text { time }\end{array}$ & & ${ }^{95} \mathrm{Zr}^{d}$ & ${ }^{106} \mathrm{Ru}$ & ${ }^{144} \mathrm{Ce}$ & ${ }^{125} \mathrm{Sb}$ & ${ }^{137} \mathrm{Cs}$ \\
\hline HT-14-8 & 14 & $6.44 \mathrm{E} 7$ & $\begin{array}{l}\text { a/a } \\
\% \text { S.D. } \\
\% \text { error }\end{array}$ & $\begin{array}{l}2.73 \mathrm{E}-3 \\
5.4 \\
3.8\end{array}$ & $\begin{array}{l}2.26 \mathrm{E}-4 \\
5.2 \\
3.0\end{array}$ & $\begin{array}{l}3.35 E-3 \\
3.1 \\
1.4\end{array}$ & $\begin{array}{l}7.53 E-5 \\
6.5 \\
4\end{array}$ & $\begin{array}{l}6.04 \mathrm{E}-3 \\
3.4 \\
0.2\end{array}$ \\
\hline HT-14-8 & $1 \mathrm{~s}$ & $6.44 \mathrm{E} 7$ & $\mathrm{a} / \mathrm{a}$ & $2.77 \mathrm{E}-3$ & $2.21 \mathrm{E}-4$ & $3.21 \mathrm{E}-3$ & $7.83 E-5$ & $6.29 \mathrm{E}-3$ \\
\hline HT-14-13 & 17 & $6.57 \mathrm{E} 7$ & $\begin{array}{l}\text { a/a } \\
\% \text { S.D. } \\
\% \text { error }\end{array}$ & $\begin{array}{l}3.40 \mathrm{E}-3 \\
3.5 \\
3.3\end{array}$ & $\begin{array}{l}2.77 \mathrm{E}-4 \\
3.8 \\
2.6\end{array}$ & $\begin{array}{l}3.99 E-3 \\
2.4 \\
1.4\end{array}$ & $\begin{array}{l}8.48 E-5 \\
5.5 \\
3.8\end{array}$ & $\begin{array}{l}6.48 \mathrm{E}-3 \\
7.5 \\
0.3\end{array}$ \\
\hline HT-14-13 & $6 \mathrm{f}$ & $6.57 \mathrm{E} 7$ & $\begin{array}{l}\mathrm{a} / \mathrm{a} \\
\% \text { S.D. }\end{array}$ & $\begin{array}{l}3.40 \mathrm{E}-3 \\
3.6\end{array}$ & $\begin{array}{l}2.73 E-4 \\
5\end{array}$ & $\begin{array}{l}3.95 E-4 \\
3.0\end{array}$ & $\begin{array}{l}8.44 \mathrm{E}-5 \\
2.6\end{array}$ & $\begin{array}{l}6.72 \mathrm{E}-3 \\
5.5\end{array}$ \\
\hline HT-14-13 & $2 \mathrm{~s}$ & $6.57 \mathrm{E} 7$ & $a / a$ & $3.40 \mathrm{E}-3$ & $2.76 \mathrm{E}-4$ & $3.99 \mathrm{E}-3$ & $7.77 \mathrm{E}-5$ & $5.93 \mathrm{E}-3$ \\
\hline HT-14-21 & 18 & $5.52 \mathrm{E} 7$ & $\begin{array}{l}\text { a/a } \\
\% \text { S.D. } \\
\% \text { error }\end{array}$ & $\begin{array}{l}4.62 \mathrm{E}-3 \\
3.2 \\
1.5\end{array}$ & $\begin{array}{l}3.82 \mathrm{E}-4 \\
5.2 \\
2.4\end{array}$ & $\begin{array}{l}5.38 \mathrm{E}-3 \\
3.2 \\
1.3\end{array}$ & $\begin{array}{l}9.35 \mathrm{E}-5 \\
10.1 \\
4.5\end{array}$ & $\begin{array}{l}5.27 \mathrm{E}-3 \\
20.4 \\
0.4\end{array}$ \\
\hline HT-14-21 & $12 \mathrm{~s}$ & $5.52 \mathrm{E} 7$ & $\begin{array}{l}\text { a/a } \\
\% \text { S.D. }\end{array}$ & $\begin{array}{l}4.60 \mathrm{E}-3 \\
3.5\end{array}$ & $\begin{array}{l}3.82 \mathrm{E}-4 \\
5.7\end{array}$ & $\begin{array}{l}5.41 \mathrm{E}-3 \\
3.4\end{array}$ & $\begin{array}{l}9.25 \mathrm{E}-5 \\
11.3\end{array}$ & $\begin{array}{l}5.65 \mathrm{E}-3 \\
3.5\end{array}$ \\
\hline HT-14-21 & $3 \mathrm{f}$ & $5.52 \mathrm{E} 7$ & $a / a$ & $4.57 \mathrm{E}-3$ & $3.86 \mathrm{E}-4$ & $5.34 \mathrm{E}-3$ & $9.12 \mathrm{E}-5$ & $3.42 \mathrm{E}-3$ \\
\hline HT-14-21L & 12 & $7.13 \mathrm{E} 7$ & $\begin{array}{l}\text { a/a } \\
\% \text { S.D. } \\
\% \text { error }\end{array}$ & $\begin{array}{l}4.98 E-3 \\
3.0 \\
3\end{array}$ & $\begin{array}{l}4.01 \mathrm{E}-4 \\
3.5 \\
1.1\end{array}$ & $\begin{array}{l}5.61 \mathrm{E}-3 \\
2.4 \\
0.8\end{array}$ & $\begin{array}{l}1.04 \mathrm{E}-4 \\
3.0 \\
2\end{array}$ & $\begin{array}{l}5.82 \mathrm{E}-3 \\
4.6 \\
0.2\end{array}$ \\
\hline HT-14-26 & 1 & $5.32 \mathrm{E} 7$ & $\begin{array}{l}\mathrm{a} / \mathrm{a} \\
\% \text { error }\end{array}$ & $\begin{array}{l}5.11 \mathrm{E}-3 \\
1.1\end{array}$ & $\begin{array}{l}3.95 \mathrm{E}-4 \\
2\end{array}$ & $\begin{array}{l}5.80 \mathrm{E}-3 \\
1.0\end{array}$ & $\begin{array}{l}9.99 \mathrm{E}-5 \\
3.3\end{array}$ & $\begin{array}{l}4.15 E-3 \\
0.3\end{array}$ \\
\hline HT-15-8 & 13 & $6.42 \mathrm{E} 7$ & $\begin{array}{l}\text { a/a } \\
\% \text { S.D. } \\
\% \text { error }\end{array}$ & $\begin{array}{l}3.33 E-3 \\
3.6 \\
4\end{array}$ & $\begin{array}{l}2.84 \mathrm{E}-4 \\
4.9 \\
3\end{array}$ & $\begin{array}{l}4.06 \mathrm{E}-3 \\
2.9 \\
1.7\end{array}$ & $\begin{array}{l}9.25 E-5 \\
4.3 \\
4\end{array}$ & $\begin{array}{l}4.65 E-3 \\
13.3 \\
0.4\end{array}$ \\
\hline HT-15-13 & 16 & $6.46 \mathrm{E} 7$ & $\begin{array}{l}\text { a/a } \\
\% \text { S.D. } \\
\% \text { error }\end{array}$ & $\begin{array}{l}3.86 \mathrm{E}-3 \\
6.7 \\
3\end{array}$ & $\begin{array}{l}3.46 \mathrm{E}-4 \\
2.3 \\
2.0\end{array}$ & $\begin{array}{l}4.76 \mathrm{E}-3 \\
1.9 \\
1.1\end{array}$ & $\begin{array}{l}9.94 \mathrm{E}-5 \\
3.4 \\
3\end{array}$ & $\begin{array}{l}4.78 E-3 \\
24.7 \\
0.3\end{array}$ \\
\hline HT-15-13 & $7 \mathrm{f}$ & $6.46 \mathrm{E} 7$ & $\begin{array}{l}\text { a/a } \\
\% \text { S.D. }\end{array}$ & $\begin{array}{l}3.78 \mathrm{E}-3 \\
3.8\end{array}$ & $\begin{array}{l}3.48 \mathrm{E}-4 \\
2.5\end{array}$ & $\begin{array}{l}4.75 E-3 \\
2.4\end{array}$ & $\begin{array}{l}9.97 \mathrm{E}-5 \\
3.5\end{array}$ & $\begin{array}{l}4.43 E-3 \\
21.2\end{array}$ \\
\hline HT-15-13 & $1 \mathrm{~s}$ & $6.46 \mathrm{E} 7$ & $a / a$ & $3.87 \mathrm{E}-3$ & $3.52 \mathrm{E}-4$ & $4.84 \mathrm{E}-3$ & $1.04 \mathrm{E}-4$ & $7.76 \mathrm{E}-3$ \\
\hline HT-15-26 & 19 & $5.25 \mathrm{E} 7$ & $\begin{array}{l}\text { a/a } \\
\% \text { S.D. } \\
\text { \% error }\end{array}$ & $\begin{array}{l}49.81 \mathrm{E}-3 \\
2.9 \\
1.1\end{array}$ & $\begin{array}{l}4.44 \mathrm{E}-4 \\
4.6 \\
2.2\end{array}$ & $\begin{array}{l}6.35 E-3 \\
2.9 \\
1\end{array}$ & $\begin{array}{l}9.78 E-5 \\
10.4 \\
4.6\end{array}$ & $\begin{array}{l}8.26 \mathrm{E}-3 \\
8.2 \\
0.2\end{array}$ \\
\hline HT-15-29 & 19 & $5.57 \mathrm{E} 7$ & $\begin{array}{l}\text { a/a } \\
\% \text { S.D. } \\
\% \text { error }\end{array}$ & $\begin{array}{l}5.29 \mathrm{E}-3 \\
5.5 \\
1.3\end{array}$ & $\begin{array}{l}4.93 \mathrm{E}-3 \\
5.8 \\
2.1\end{array}$ & $\begin{array}{l}6.64 \mathrm{E}-4 \\
5.0 \\
1.1\end{array}$ & $\begin{array}{l}1.14 \mathrm{E}-4 \\
6.4 \\
4\end{array}$ & $\begin{array}{l}5.57 \mathrm{E}-3 \\
3.5 \\
0.4\end{array}$ \\
\hline
\end{tabular}

${ }^{a}$ Irradiation numbers followed by $\mathrm{L}$ are the same or part of the same particles of samples with the same number without $L$, except that $L$ denotes those samples that have been hot chlorine leached.

${ }^{b}$ Numbers not followed by letters are of particles not leach tested. Those followed by "s" survived leaching; those followed by " $\mathrm{f}$ " failed leaching.

${ }^{c}$ The values given following a/a are in atoms of fission product at the end of irradiation per initial atom of ${ }^{232} \mathrm{Th}$. The initial atoms of ${ }^{232}$ Th per particle used in the calculations were averages; $7.542 \mathrm{E} 17$ atoms in OR-1840 particles in holders $-8,-21$, and -29 ; and $1.522 \mathrm{E} 18$ atoms in OR-1849 particles in holders -13 and -26 . The decay time to the time of analysis is given for comparison with the standard deviations and errors.

${ }^{d}$ The ${ }^{95} \mathrm{Zr}$ values were corrected for the ${ }^{154} \mathrm{Eu}$ contribution in the gamma-ray peaks. Since ${ }^{95} \mathrm{Zr}$ decayed more rapidly, many gamma-ray spectra showed no ${ }^{95} \mathrm{Zr}$; therefore, in some samples the number of ${ }^{95} \mathrm{Zr}$ values was less than the number of particles. For these samples the number of ${ }^{95} \mathrm{Zr}$ values is given as a superscript.

${ }^{e}$ The \% S.D. is the standard deviation of the fission product concentrations in the sample.

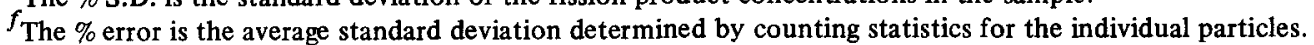


Table B.2. Calculated fission product in Biso-coated thoria particles from irradiation capsule HT-12 (atoms per initial atom of thorium)

\begin{tabular}{|c|c|c|c|c|c|}
\hline HOLDER & FLUXX & $232 \mathrm{TH}$ & $233 P A$ & $23 \angle P A$ & 23311 \\
\hline 8 & $3.065 E+15$ & $9.567 E-\cap 1$ & $2.226 E-02$ & $3.50 \& F-05$ & $7.269 E-03$ \\
\hline 13 & $3.576 E+15$ & $9 \cdot 496 E-01$ & $2 \cdot 525 E-02$ & $4.502 E-05$ & $7 \cdot 473 E-03$ \\
\hline 21 & $4 \cdot 366 E+15$ & $9.388 E-01$ & $2.953 E-02$ & $6 \cdot 138 F-05$ & $7 \cdot 585 E-03$ \\
\hline 29 & $4 \cdot 505 E+15$ & 9.37 OE- 01 & $3.025 E-02$ & $6 \cdot 436 E-05$ & $7.586 E-03$ \\
\hline 26 & $4.598 E+15$ & $9.357 E-01$ & 3.072E-02 & $6.6365-05$ & $7.584 E-03$ \\
\hline HOLDER & FLUX & 23411 & 23511 & 23611 & 90SR \\
\hline 8 & $3.065 E+15$ & $4.597 E-03$ & $5.008 E-0 \triangle$ & $6.082 E-05$ & $5.783 E-04$ \\
\hline 13 & $3.576 E+15$ & $5.8 \triangle O E-03$ & $6.93 \Delta E-0 \triangle$ & $1.00 \Delta E-0 \Delta$ & $7.34 \Delta E-0 \triangle$ \\
\hline 21 & $4 \cdot 366 E+15$ & $7.848 E-03$ & $1.030 E-03$ & $1.877 E-04$ & $9.9 .34 E-0 \triangle$ \\
\hline 29 & $4 \cdot 505 E+15$ & $8 \cdot 208 E-03$ & $1.093 E-03$ & $2.066 E-04$ & $1.0 \Delta 1 E-03$ \\
\hline 26 & $\triangle .598 E+15$ & Q. $449 E-03$ & $1.136 E-03$ & $2.198 E-04$ & $1.073 E-03$ \\
\hline OLDER & FLUX & $95 Z R$ & $106 R U$ & $137 \mathrm{CS}$ & $1 \triangle \triangle C E$ \\
\hline 8 & $3.065 E+15$ & $4.70 \Delta E-0 \Delta$ & $2.215 E-05$ & $5.8 .14 E-0 \triangle$ & $3.95 \Delta E-0 \triangle$ \\
\hline 13 & $3.576 E+15$ & $5.983 E-04$ & $2.846 E-05$ & $7.394 E-04$ & $5.0 \triangle O E-O \triangle$ \\
\hline 21 & $4.366 E+15$ & $8 \cdot 113 \varepsilon-04$ & $3.922 E-05$ & $1.002 E-03$ & $6.861 E-04$ \\
\hline 29 & $4.505 E+15$ & $8.506 E-04$ & $4.123 F-05$ & $1.051 E-03$ & $7 \cdot 199 E-04$ \\
\hline 26 & $4.598 E+15$ & $8.771 E-0 \triangle$ & $4 \cdot 260 E-05$ & $1.083 E-0.3$ & $7.4 ? 7 E-0 \triangle$ \\
\hline OLDER & FLUX & $125 \mathrm{SB}$ & FIMA & & \\
\hline 8 & $3.065 E+15$ & $8.846 E-06$ & $8.616 E-0.3$ & & \\
\hline 13 & $3.576 E+15$ & $1.113 E-05$ & $1.097 E-0 ?$ & & \\
\hline 21 & $4 \cdot 366 E+15$ & 1. $481 E-05$ & $1.4915-02$ & & \\
\hline 29 & $4.505 E+15$ & $1.547 E-05$ & $1.56 \Delta E-02$ & & \\
\hline 26 & $4.598 E+15$ & 1. $592 E-05$ & $1.613 E-02$ & & \\
\hline
\end{tabular}


Table B.3. Calculated fission product in Biso-coated thoria particles from irradiation capsule HT-13 (atoms per initial atom of thorium)

\begin{tabular}{|c|c|c|c|c|c|}
\hline HOLDER & FLUX & $232 \mathrm{TH}$ & $233 P A$ & $23 \triangle P A$ & 23311 \\
\hline 8 & $3.065 E+15$ & $9.065 \varepsilon-01$ & $2.658 E-02$ & $3.540 E-05$ & $1.251 E-02$ \\
\hline 13 & $3.576 E+15$ & $8.918 E-01$ & $2.951 E-02$ & $\triangle .491 E-05$ & $1.2265-\cap ?$ \\
\hline 21 & $4 \cdot 366 E+15$ & $8.695 E-01$ & $3.341 E-02$ & $6.016 E-05$ & $1.179 E-02$ \\
\hline 29 & $4.505 E+15$ & $8.656 E-01$ & $3.403 E-02$ & $6 \cdot 289 E-05$ & $1.170 E-02$ \\
\hline 26 & $4.598 E+15$ & $8.630 E-01$ & $3.443 E-0 ?$ & $6.470 E-05$ & $1.163 E-02$ \\
\hline HOLDER & FL.UXX & 23411 & 23511 & 23611 & 9NSR \\
\hline 8 & $3.065 E+15$ & $1 \cdot 280 E-02$ & $1.995 E-03$ & $6.308 E-04$ & $? \cdot 581 E-03$ \\
\hline 13 & $3.576 E+15$ & $1 \cdot 532 E-02$ & $2.501 E-03$ & $9.541 E-04$ & $3 \cdot 138 E-03$ \\
\hline 21 & $4 \cdot 366 E+15$ & $1.890 E-02$ & $3.239 E-03$ & $1.580 E-0.3$ & $\triangle .020 E-03$ \\
\hline 29 & $4 \cdot 505 E+15$ & $1 \cdot 948 E-02$ & $3.362 E-03$ & $1.705 E-03$ & $\Delta .178 E-03$ \\
\hline 26 & $4 \cdot 598 E+15$ & 1.986E-0? & $3 \cdot 443 E-03$ & $1.790 E-03$ & $4 \cdot 28.3 F-03$ \\
\hline HOLDER & FLUX & $952 R$ & 106RII & $137 \mathrm{CS}$ & $1 \triangle \triangle C F$ \\
\hline 8 & $3.065 E+15$ & $1.756 E-03$ & $9.933 E-05$ & $2.612 E-03$ & $1.700 E-03$ \\
\hline 13 & $3.576 E+15$ & $2 \cdot 137 E-03$ & $1.229 E-04$ & $3.18 \triangle E-03$ & $2.082 E-0.3$ \\
\hline 21 & $4.366 E+15$ & $2.743 E-03$ & $1.618 E-04$ & $4.09 \Delta E-03$ & $0.695 E-0.3$ \\
\hline 29 & $4.505 E+15$ & $2.853 E-03$ & $1.689 E-04$ & $4.258 E-03$ & $2.806 E-03$ \\
\hline 26 & $4 \cdot 598 E+15$ & $2 \cdot 926 E-0.3$ & $1.737 E-04$ & $4.3675-0.3$ & $2 \cdot 880 E-0.3$ \\
\hline HOLDER & FLIIX & $125 S B$ & FINA & & \\
\hline 8 & $3.065 E+15$ & $3.817 E-05$ & $3.893 E-02$ & & \\
\hline 13 & $3.576 E+15$ & $\Delta .560 E-05$ & $4.757 E-02$ & & \\
\hline 21 & $4 \cdot 366 E+15$ & $5.680 E-05$ & $6 \cdot 139 E-02$ & & \\
\hline 29 & $4.505 E+15$ & $5.874 E-05$ & $6 \cdot 389 E-02$ & & \\
\hline 26 & $4.598 E+15$ & $6.003 E-05$ & $6.556 E-02$ & & \\
\hline
\end{tabular}


Table B.4. Calculated fission product in Biso-coated thoria particles from irradiation capsule HT-14 (atoms per initial atom of thorium)

\begin{tabular}{|c|c|c|c|c|c|}
\hline HOLDER & FL. $11 x$ & $232 T H$ & $233 P A$ & $23 \triangle P A$ & 23311 \\
\hline 8 & $3.065 \Xi+15$ & $8.5 \angle 5 E-01$ & $2.786 E-02$ & 4.41 OF- $\cap 5$ & $1.150 F-C 2$ \\
\hline 13 & $3.576 E+15$ & $8 \cdot 324 E-01$ & $3.0 \triangle 7 E-n ?$ & $5.456 E-05$ & $1.081 \mathrm{E}-02$ \\
\hline 21 & $4 \cdot 366 E+15$ & $7.9935-01$ & $3 \cdot 376 E-02$ & $7.045 F-05$ & $9.815 F-03$ \\
\hline 29 & $4.505 E+15$ & $7 \cdot 9365-01$ & $3 \cdot 426 E-0 ?$ & $7.318 E-05$ & $9.651 F-0.3$ \\
\hline 26 & $4.598 E+15$ & $7.898 F-01$ & $3.457 E-02$ & $7.499 E-05$ & $9.543 F-0.3$ \\
\hline ICL DER & FLUX & 23411 & 2.3511 & 23611 & $90 S R$ \\
\hline 8 & $3.065 E+15$ & 1.839E-0? & $3 \cdot 246 E-03$ & $1.896 E-03$ & $5.3965-0.3$ \\
\hline 13 & $3.576 E+15$ & $2.093 E-02$ & $3.788 E-03$ & $2.681 E-03$ & $6 \cdot 414 F-03$ \\
\hline 21 & $4 \cdot 366 E+15$ & $2 \cdot 406 E-0 ?$ & $4.467 E-03$ & $4.051 E-03$ & $7.981 E-03$ \\
\hline 29 & $4.505 E+15$ & $2 \cdot 452 E-02$ & $4.568 E-03$ & $\Delta .307 E-03$ & $8.255 E-03$ \\
\hline 26 & $4.598 E+15$ & $2 \cdot 481 E-02$ & $4 \cdot 632 E-03$ & $\triangle .479 E-03$ & $8.439 F-03$ \\
\hline OLDER & FLIIX & $952 R$ & $106 R 11$ & $137 \mathrm{CS}$ & $1 \Delta \Delta C, F$ \\
\hline 8 & $3.065 E+15$ & $3 \cdot 103 E-0.3$ & $2.070 E-04$ & 5. $\triangle 98 E-03$ & $3 \cdot 4305-03$ \\
\hline 13 & $3.576 E+15$ & $3.686 E-03$ & $2.510 E-04$ & $6.558 E-03$ & $4.107 F-03$ \\
\hline 21 & $4.366 E+15$ & $4.587 E-03$ & $3.215 E-0 \Delta$ & $8.201 E-03$ & $5.16 \Delta E-03$ \\
\hline 29 & $4.505 E+15$ & $4.746 E-03$ & $3 \cdot 342 E-0 \triangle$ & $8.492 E-03$ & $5.352 F-03$ \\
\hline 26 & $4 \cdot 598 E+15$ & $4.852 E-03$ & $3.427 E-04$ & $8.685 E-03$ & $5.477 E-03$ \\
\hline HCLDER & FLUX & 12559 & FIMA & & \\
\hline 8 & $3.065 E+15$ & $7.695 E-05$ & $8.239 E-02$ & & \\
\hline 13 & $3.576 E+15$ & $8.953 E-05$ & $9.856 E-02$ & & \\
\hline 21 & $4 \cdot 366 E+15$ & $1.079 E-04$ & $1.238 E-01$ & & \\
\hline 29 & $4.505 E+15$ & $1.110 E-04$ & $1.283 E-01$ & & \\
\hline 26 & $4.598 E+15$ & $1.131 E-04$ & $1.312 E-01$ & & \\
\hline
\end{tabular}


Table B.5. Calculated fission product in Biso-coated thoria particles from irradiation capsule HT-15 (atoms per initial atom of thorium)

\begin{tabular}{|c|c|c|c|c|c|}
\hline HOLDER & FLUX. & 232TH & $233 P A$ & $23 \triangle P A$ & 23 \\
\hline 8 & $3.065 E+15$ & 8. 322E-01 & $2.668 E-02$ & $4.223 E-05$ & $1.1 \angle O E-O ?$ \\
\hline 13 & $3.576 E+15$ & $8.072 E-01$ & $2.906 E-02$ & $5.201 E-05$ & $1.06 \cap E-0 ?$ \\
\hline 21 & $4 \cdot 366 E+15$ & $7.6995-01$ & $3.197 E-0 ?$ & $6.671 E-05$ & $9.495 E-0.3$ \\
\hline 29 & $4.505 E+15$ & $7.635 E-01$ & $3 \cdot 2415-02$ & $6.921 F-n 5$ & $9.315 E-03$ \\
\hline 26 & $4.598 E+15$ & $7.592 E-01$ & $3.268 E-02$ & $7.087 E-05$ & $9.197 E-03$ \\
\hline OLDER & FLUIX & $234 ! 1$ & $235 ! !$ & $236 ! 1$ & $90 \mathrm{SR}$ \\
\hline 8 & $3.065 E+15$ & $1.975 E-02$ & $3.588 E-03$ & $2.579 E-03$ & $6.737 E-03$ \\
\hline 13 & $3.576 E+15$ & $2 \cdot 205 E-02$ & $4.085 E-03$ & $3.561 E-03$ & $7.953 E-03$ \\
\hline 21 & $4 \cdot 366 E+15$ & $2.469 E-02$ & $4.667 E-03$ & $5.2095-0.3$ & $9.801 E-03$ \\
\hline 29 & $4.505 E+15$ & $2 \cdot 506 E-02$ & $4.749 E-03$ & $5.509 E-03$ & $1.012 E-02$ \\
\hline 26 & $4.598 E+15$ & $2.529 E-02$ & $4.800 E-03$ & $5.710 E-03$ & $1.034 E-02$ \\
\hline OLDER & FLUXX & 952.R & $106 R ! 1$ & $137 \mathrm{CS}$ & $1 \angle \triangle C E$ \\
\hline 8 & $3.065 E+15$ & $3.521 E-03$ & $2.559 E-04$ & $6.883 E-03$ & $4.18 \Delta E-03$ \\
\hline 13 & $3.576 E+15$ & $4.149 E-03$ & $3.083 E-04$ & $8.1565-03$ & $\triangle .97 \Delta E-03$ \\
\hline 21 & $4.366 E+15$ & $5 \cdot 105 E-03$ & $3.910 E-04$ & $1.011 \mathrm{E}-02$ & $6.190 E-0.3$ \\
\hline 29 & $4.505 E+15$ & $5.271 E-03$ & $4.058 E-04$ & $1.0 \triangle 5 E-0 ?$ & $6 . \Delta O \triangle E-\cap 3$ \\
\hline 26 & $4 \cdot 598 E+15$ & $5 \cdot 382 E-03$ & $4 \cdot 156 E-0 \Delta$ & $1.068 E-02$ & $6.5 \Delta 6 E-03$ \\
\hline OLDER & FLUX & 12553 & FIMA & & \\
\hline 8 & $3.065 E+15$ & $9 \cdot 463 E-05$ & $1.034 E-01$ & & \\
\hline 13 & $3.576 E+15$ & $1.093 E-04$ & $1 \cdot 229 E-01$ & & \\
\hline 21 & $4 \cdot 366 E+15$ & $1.304 E-04$ & $1.529 E-01$ & & \\
\hline 29 & $4.505 E+15$ & $1.340 E-04$ & $1.582 E-01$ & & \\
\hline 26 & $4 \cdot 598 E+15$ & $1.364 E-04$ & $1.617 E-01$ & & \\
\hline
\end{tabular}


Table B.6. Fission product inventories in Biso-coated $\mathrm{ThO}_{2}$ particles from irradiation capsule $\mathrm{HT}-12$, calculated for various neutron flux levels (atoms per initial atom of thorium)

\begin{tabular}{|c|c|c|c|c|}
\hline FLUX & $232 \mathrm{TH}$ & 233PA & $234 \mathrm{PA}$ & $233 U$ \\
\hline $2.7000 \mathrm{E}+15$ & $9.6172 \mathrm{E}-01$ & $2.0010 \mathrm{E}-02$ & $2.84 I I E-05$ & $7.0332 \mathrm{E}-03$ \\
\hline $3.0000 \mathrm{E}+15$ & $9.5756 \mathrm{E}-01$ & $2.186 \mathrm{TE}-02$ & $3.3858 \mathrm{E}-05$ & $7.2329 \mathrm{E}-03$ \\
\hline $3.3000 \mathrm{E}+15$ & $9.5342 \mathrm{E}-01$ & $2.3659 \mathrm{E}-02$ & $3.9565 \mathrm{E}-05$ & $7.3788 \mathrm{E}-0$ \\
\hline $3.6000 \mathrm{E}+15$ & $9.4929 \mathrm{E}-01$ & $2.5388 \mathrm{E}-02$ & $4.5490 \mathrm{E}-05$ & $7.4800 \mathrm{E}-0$ \\
\hline $3.9000 \mathrm{E}+15$ & $9.4519 \mathrm{E}-01$ & $2.7056 \mathrm{E}-02$ & $5.1599 \mathrm{E}-05$ & $7.5442 \mathrm{E}-0$ \\
\hline $4.2000 \mathrm{E}+15$ & $9.4110 \mathrm{E}-01$ & $2.8666 \mathrm{E}-02$ & $5.7860 \mathrm{E}-05$ & $7.5778 \mathrm{E}-0$ \\
\hline $4.5000 E+15$ & $9.3702 \mathrm{E}-01$ & $3.0219 \mathrm{E}-02$ & $6.4244 \mathrm{E}-05$ & $7.5861 E-0$ \\
\hline $4.8000 \mathrm{E}+15$ & $9.3297 \mathrm{E}-01$ & $3.1717 \mathrm{E}-02$ & $7.0726 \mathrm{E}-05$ & $7.5737 \mathrm{E}-0$ \\
\hline $5.1000 \mathrm{E}+15$ & $9.2893 \mathrm{E}-01$ & $3.3162 \mathrm{E}-02$ & $7.7282 \mathrm{E}-05$ & $7.5443 \mathrm{E}-0$ \\
\hline $5.4000 E+15$ & $9.2491 \mathrm{E}-01$ & $3.4555 \mathrm{E}-02$ & $8.3891 E-05$ & $7.5010 E-0$ \\
\hline FLUX & $234 U$ & $235 \mathrm{U}$ & $236 u$ & 9OSR \\
\hline $2.7000 E+15$ & $3.7505 E-03$ & $3.7855 \mathrm{E}-04$ & $3.9853 \mathrm{E}-05$ & $4.7309 \mathrm{E}-0$ \\
\hline $3.0000 \mathrm{E}+15$ & $4.4426 \mathrm{E}-03$ & $4.7785 \mathrm{E}-04$ & $5.6634 \mathrm{E}-05$ & $5.5899 \mathrm{E}-0$ \\
\hline $3.3000 E+15$ & $5.1606 \mathrm{E}-03$ & $5.8628 \mathrm{E}-04$ & $7.7413 \mathrm{E}-05$ & $6.4871 \mathrm{E}-0$ \\
\hline $3.6000 \mathrm{E}+15$ & $5.8992 \mathrm{E}-03$ & $7.0280 \mathrm{E}-04$ & $1.0249 \mathrm{E}-05$ & $7.4185 \mathrm{E}-\mathrm{C}$ \\
\hline $3.9000 \mathrm{E}+15$ & $6.6538 \mathrm{E}-03$ & $8.2636 \mathrm{E}-04$ & $1.3212 \mathrm{E}-05$ & $8.3814 \mathrm{E}-0$ \\
\hline $4.2000 \mathrm{E}+15$ & $7.4201 \mathrm{E}-03$ & $9.5595 \mathrm{E}-04$ & $1.6652 \mathrm{E}-04$ & $9.3732 \mathrm{E}-\mathrm{C}$ \\
\hline $4.5000 \mathrm{E}+15$ & $8.1944 \mathrm{E}-03$ & $1.0906 \mathrm{E}-03$ & $2.0585 \mathrm{E}-04$ & $1.0392 \mathrm{E}-\mathrm{C}$ \\
\hline $4.8000 E+15$ & $8.9734 E-03$ & $1.2295 \mathrm{E}-03$ & $2.5026 \mathrm{E}-04$ & $1.1436 \mathrm{E}-0$ \\
\hline $5.1000 \mathrm{E}+15$ & $9.7543 \mathrm{E}-03$ & $1.3718 \mathrm{E}-03$ & $2.9983 \mathrm{E}-04$ & $1.2504 \mathrm{E}-\mathrm{C}$ \\
\hline $5.4000 \mathrm{E}+15$ & $1.0534 \mathrm{E}-02$ & $1.5167 \mathrm{E}-03$ & $3.5464 \mathrm{E}-04$ & $1.3596 \mathrm{E}-0$ \\
\hline FLUX & 95ZR & 106RU & $137 \mathrm{CS}$ & $144 \mathrm{CE}$ \\
\hline $2.7000 \mathrm{E}+15$ & $3.8451 \mathrm{E}-04$ & $1.7972 \mathrm{E}-05$ & 4.7517E-04 & $3.2271 \mathrm{E}-0$ \\
\hline $3.0000 \mathrm{E}+15$ & $4.5467 \mathrm{E}-04$ & $2.1380 \mathrm{E}-05$ & $5.6191 \mathrm{E}-04$ & $3.8202 \mathrm{E}-0$ \\
\hline $3.3000 \mathrm{E}+15$ & $5.2805 \mathrm{E}-04$ & $2.4982 \mathrm{E}-05$ & $6.5262 \mathrm{E}-04$ & $4.4425 \mathrm{E}-0$ \\
\hline $3.6000 \mathrm{E}+15$ & $6.0438 \mathrm{E}-04$ & $2.8767 \mathrm{E}-05$ & $7.4694 \mathrm{E}-04$ & $5.0918 \mathrm{E}-0$ \\
\hline $3.9000 \mathrm{E}+15$ & $6.8345 \mathrm{E}-04$ & $3.2729 \mathrm{E}-05$ & $8.4457 \mathrm{E}-04$ & $5.7664 \mathrm{E}-\mathrm{C}$ \\
\hline $4.2000 \mathrm{E}+15$ & $7.6508 \mathrm{E}-04$ & $3.6860 \mathrm{E}-05$ & $9.4529 \mathrm{E}-04$ & $6.4649 \mathrm{E}-\mathrm{C}$ \\
\hline $4.5000 \mathrm{E}+15$ & $8.4911 \mathrm{E}-04$ & $4.1155 \mathrm{E}-05$ & $1.0489 \mathrm{E}-03$ & $7.1862 \mathrm{E}-\mathrm{C}$ \\
\hline $4.8000 \mathrm{E}+15$ & $9.3544 \mathrm{E}-04$ & $4.571] \mathrm{E}-05$ & $1.1553 \mathrm{E}-03$ & $7.9293 \mathrm{E}-\mathrm{C}$ \\
\hline $5.1000 \mathrm{E}+15$ & $1.0240 \mathrm{E}-03$ & $5.0226 \mathrm{E}-05$ & $1.2642 \mathrm{E}-03$ & $8.6935 \mathrm{E}-\mathrm{C}$ \\
\hline $5.4000 \mathrm{E}+15$ & $1.1146 \mathrm{E}-03$ & $5.4992 \mathrm{E}-05$ & $1.3757 \mathrm{E}-03$ & $9.4781 \mathrm{E}-0$ \\
\hline FLUX & $125 \mathrm{SB}$ & FIMA & & \\
\hline $2.7000 \mathrm{E}+15$ & $7.2803 \mathrm{E}-06$ & $7.0361 \mathrm{E}-03$ & & \\
\hline $3.0000 \mathrm{E}+15$ & $8.5603 E-06$ & $8.3275 \mathrm{E}-03$ & & \\
\hline $3.3000 \mathrm{E}+15$ & $9.8815 \mathrm{E}-06$ & $9.6801 \mathrm{E}-03$ & & \\
\hline $3.6000 E+15$ & $1.1236 \mathrm{E}-05$ & $1.1089 \mathrm{E}-02$ & & \\
\hline $3.9000 \mathrm{E}+15$ & $1.2619 \mathrm{E}-05$ & $1.2550 \mathrm{E}-02$ & & \\
\hline $4.2000 \mathrm{E}+15$ & $1.4024 \mathrm{E}-05$ & $1.4060 \mathrm{E}-02$ & & \\
\hline $4.5000 \mathrm{E}+15$ & $1.5449 \mathrm{E}-05$ & $1.5616 \mathrm{E}-02$ & & \\
\hline $4.8000 \mathrm{E}+15$ & $1.6888 \mathrm{E}-05$ & $1.7216 \mathrm{E}-02$ & & \\
\hline $5.1000 \mathrm{E}+15$ & $1.8341 \mathrm{E}-05$ & $1.8859 \mathrm{E}-02$ & & \\
\hline $5.4000 \mathrm{E}+15$ & $1.9804 \mathrm{E}-05$ & $2.0542 \mathrm{E}-02$ & & \\
\hline
\end{tabular}


Table B.7. Fission product inventories in Biso-coated $\mathrm{ThO}_{2}$ particles from irradiation capsule HT-13, calculated for various neutron flux levels (atoms per initial atom of thorium)

\begin{tabular}{|c|c|c|c|c|}
\hline FLUX & 232TH & 233PA & $234 \mathrm{PA}$ & $233 \mathrm{U}$ \\
\hline $2.7000 \mathrm{E}+15$ & $9.171 \% \mathrm{E}-01$ & $2.4275 \mathrm{E}-02$ & $2.8900 \mathrm{E}-05$ & $1.2615 \mathrm{E}-$ \\
\hline $3.0000 \mathrm{E}+15$ & $9.0838 \mathrm{E}-01$ & $2.6184 \mathrm{E}-02$ & $3.4216 \mathrm{E}-05$ & $1.2532 \mathrm{E}-$ \\
\hline $3.3000 \mathrm{E}+15$ & 8.9969E-01 & $2.7969 \mathrm{E}-02$ & $3.9718 \mathrm{E}-05$ & $1.2406 \mathrm{E}-$ \\
\hline $3.6000 \mathrm{E}+15$ & $8.9109 \mathrm{E}-01$ & $2.9637 \mathrm{E}-02$ & $4.5363 \mathrm{E}-05$ & $1.2251 \mathrm{E}-1$ \\
\hline $3.9000 \mathrm{E}+15$ & $8.8257 \mathrm{E}-01$ & $3.1195 \mathrm{E}-02$ & $5.1 I I I E-05$ & $1.2077 \mathrm{E}-$ \\
\hline $4.2000 E+15$ & $8.7413 \mathrm{E}-01$ & $3.2649 \mathrm{E}-02$ & $5.6928 \mathrm{E}-05$ & $1.1892 \mathrm{E}-$ \\
\hline $4.5000 \mathrm{E}+15$ & $8.6577 \mathrm{E}-01$ & $3.4005 \mathrm{E}-02$ & $6.2783 \mathrm{E}-05$ & $1.1699 \mathrm{E}-$ \\
\hline $4.8000 \mathrm{E}+15$ & $8.5749 \mathrm{E}-01$ & $3.5270 \mathrm{E}-02$ & $6.8650 \mathrm{E}-05$ & $1.1501 \mathrm{E}-$ \\
\hline $5.1000 \mathrm{E}+15$ & $8.4929 \mathrm{E}-01$ & $3.6448 \mathrm{E}-02$ & $7.4504 \mathrm{E}-05$ & $1.1302 \mathrm{E}-$ \\
\hline $5.4000 \mathrm{E}+15$ & $8.4116 \mathrm{E}-01$ & $3.7544 \mathrm{E}-02$ & $8.0325 \mathrm{E}-05$ & $1.1103 \mathrm{E}-$ \\
\hline FLUX & $234 \mathrm{U}$ & $235 \mathrm{U}$ & $236 \mathrm{U}$ & 90SR \\
\hline $2.7000 E+15$ & $1.0924 \mathrm{E}-02$ & $1.6305 \mathrm{E}-03$ & $4.4194 \mathrm{E}-04$ & $2.1889 \mathrm{E}-$ \\
\hline $3.0000 \mathrm{E}+15$ & $1.2469 \mathrm{E}-02$ & $1.9300 \mathrm{E}-03$ & $5.9427 \mathrm{E}-04$ & $2.5099 \mathrm{E}-$ \\
\hline $3.3000 \mathrm{E}+15$ & $1.3976 \mathrm{E}-02$ & $2.2289 \mathrm{E}-03$ & $7.7074 \mathrm{E}-04$ & $2.8351 \mathrm{E}-$ \\
\hline $3.6000 \mathrm{E}+15$ & $1.5435 \mathrm{E}-02$ & $2.5235 \mathrm{E}-03$ & $9.7064 \mathrm{E}-04$ & $3.1642 \mathrm{E}-$ \\
\hline $3.9000 \mathrm{E}+15$ & 1.6839E-02 & $2.8112 \mathrm{E}-03$ & I.1929E-03 & $3.4968 \mathrm{E}-$ \\
\hline $4.2000 E+15$ & $1.8181 \mathrm{E}-02$ & $3.0897 \mathrm{E}-03$ & $1.4365 \mathrm{E}-03$ & $3.8327 \mathrm{E}-$ \\
\hline $4.5000 \mathrm{E}+15$ & $1.9458 \mathrm{E}-02$ & $3.3575 \mathrm{E}-03$ & $1.6998 \mathrm{E}-03$ & $4.1716 \mathrm{E}-$ \\
\hline $4.8000 E+15$ & $2.0668 \mathrm{E}-02$ & $3.6136 \mathrm{E}-03$ & $1.9815 \mathrm{E}-03$ & $4.5134 \mathrm{E}-$ \\
\hline $5.1000 \mathrm{E}+15$ & $2.1809 \mathrm{E}-02$ & $3.8571 \mathrm{E}-03$ & $2.2800 \mathrm{E}-03$ & $4.8579 \mathrm{E}-\mathrm{C}$ \\
\hline $5.4000 \mathrm{E}+15$ & $2.2881 \mathrm{E}-02$ & $4.0876 \mathrm{E}-03$ & $2.5938 \mathrm{E}-03$ & $5.2048 \mathrm{E}-\mathrm{C}$ \\
\hline FLUXX & 95ZR & 106RU & $137 \mathrm{CS}$ & $144 \mathrm{CE}$ \\
\hline $2.7000 \mathrm{E}+15$ & $1.4895 \mathrm{E}-03$ & $8.3213 \mathrm{E}-05$ & $2.211 \mathrm{TE}-03$ & $1 . \overline{4} 358 \mathrm{E}-$ \\
\hline $3.0000 \mathrm{E}+15$ & 1.7077E-03 & $9.6397 \mathrm{E}-05$ & $2.5397 \mathrm{E}-03$ & $1.6525 \mathrm{E}-$ \\
\hline $3.3000 \mathrm{E}+15$ & $1.9295 \mathrm{E}-03$ & $1.1002 \mathrm{E}-04$ & $2.8729 \mathrm{E}-03$ & $1.8738 \mathrm{E}-$ \\
\hline $3.6000 \mathrm{E}+15$ & $2.1546 \mathrm{E}-03$ & $1.2407 \mathrm{E}-04$ & $3.2110 \mathrm{E}-03$ & $2.0996 \mathrm{E}-\mathrm{C}$ \\
\hline $3.9000 \mathrm{E}+15$ & $2.3829 \mathrm{E}-03$ & $1.3852 E-04$ & $3.5536 \mathrm{E}-03$ & $2.3296 \mathrm{E}-($ \\
\hline $4.2000 \mathrm{E}+15$ & $2.6142 \mathrm{E}-03$ & $1.5337 \mathrm{E}-04$ & $3.9005 \mathrm{E}-03$ & $2.5636 \mathrm{E}-$ \\
\hline $4.5000 \mathrm{E}+15$ & $2.8484 \mathrm{E}-03$ & $1.6860 \mathrm{E}-04$ & $4.2515 \mathrm{E}-03$ & $2.8013 \mathrm{E}-\mathrm{C}$ \\
\hline $4.8000 \mathrm{E}+15$ & $3.0852 \mathrm{E}-03$ & $1.8419 E-04$ & $4.6064 \mathrm{E}-03$ & $3.0427 \mathrm{E}-\mathrm{C}$ \\
\hline $5.1000 \mathrm{E}+15$ & $3.3247 \mathrm{E}-03$ & $2.0013 \mathrm{E}-04$ & $4.9649 E-03$ & $3.2875 \mathrm{E}-$ \\
\hline $5.4000 \mathrm{E}+15$ & $3.5664 \mathrm{E}-03$ & $2.1639 \mathrm{E}-04$ & $5.3268 \mathrm{E}-03$ & $3.5354 \mathrm{E}-\mathrm{C}$ \\
\hline
\end{tabular}

FLUXX

$2.7000 \mathrm{E}+15$

$3.0000 \mathrm{E}+15$

$3.3000 \mathrm{E}+15$

$3.6000 \mathrm{E}+15$

$3.9000 \mathrm{E}+15$

4.2000E+15

$4.5000 \mathrm{E}+15$

$4.8000 \mathrm{E}+15$

$5.1000 \mathrm{E}+15$

$5.4000 \mathrm{E}+15$
125SB

$3.2769 \mathrm{E}-05$

3.7203E-05

4.1596E-05

4.5940E-05

$5.0234 \mathrm{E}-05$

$5.4476 \mathrm{E}-05$

$5.8666 \mathrm{E}-05$

$6.2806 \mathrm{E}-05$

$6.6895 \mathrm{E}-05$

$7.0936 \mathrm{E}-05$
FIMA

3.2935E-02

3. 7878E-02

4. $2919 \mathrm{E}-02$

4. 8050E-02

5.3268 E-02

5.8570E-02

6.3952E-02

6.94IIE-02

$7.4944 \mathrm{E}-02$

$8.054 \mathrm{TE}-02$ 
Table B.8. Fission product inventories in Biso-coated $\mathrm{ThO}_{2}$ particles from irradiation capsule HT-14, calculated for various neutron flux levels (atoms per initial atom of thorium)

\begin{tabular}{|c|c|c|c|c|}
\hline FLUX & $232 \mathrm{TH}$ & 233PA & $234 \mathrm{PA}$ & $233 \mathrm{U}$ \\
\hline $2.7000 E+15$ & $8.7064 \mathrm{E}-01$ & $2.5711 E-02$ & $3.6682 \mathrm{E}-05$ & $1.2016 \mathrm{E}-02$ \\
\hline $3.0000 E+15$ & $8.5734 \mathrm{E}-01$ & $2.7489 \mathrm{E}-02$ & $4.2764 \mathrm{E}-05$ & $1.1593 \mathrm{E}-02$ \\
\hline $3.3000 \mathrm{E}+15$ & $8.4424 \mathrm{E}-01$ & $2.9109 \mathrm{E}-02$ & $4.8901 E-05$ & $1.1178 \mathrm{E}-02$ \\
\hline $3.6000 E+15$ & $8.3135 \mathrm{E}-01$ & $3.0583 \mathrm{E}-02$ & $5.5041 \mathrm{E}-05$ & $1.0776 \mathrm{E}-02$ \\
\hline $3.9000 E+15$ & $8.1865 \mathrm{E}-01$ & $3.1923 \mathrm{E}-02$ & $6.1140 \mathrm{E}-05$ & $1.0388 \mathrm{E}-02$ \\
\hline $4.2000 E+15$ & $8.0615 \mathrm{E}-01$ & $3.3138 \mathrm{E}-02$ & $6.7162 \mathrm{E}-05$ & $1.0015 \mathrm{E}-02$ \\
\hline $4.5000 \mathrm{E}+1.5$ & $7.9383 \mathrm{E}-01$ & $3.4237 \mathrm{E}-02$ & $7.3077 \mathrm{E}-05$ & $9.6570 \mathrm{E}-03$ \\
\hline $4.8000 \mathrm{E}+15$ & $7.8171 \mathrm{E}-01$ & $3.5229 \mathrm{E}-02$ & $7.8862 \mathrm{E}-05$ & $9.3148 \mathrm{E}-03$ \\
\hline $5.1000 \mathrm{E}+15$ & $7.6977 \mathrm{E}-01$ & $3.6122 \mathrm{E}-02$ & $8.4497 \mathrm{E}-05$ & $8.9874 \mathrm{E}-03$ \\
\hline $5.4000 \mathrm{E}+15$ & $7.5801 \mathrm{E}-01$ & $3.6923 \mathrm{E}-02$ & $8.9966 \mathrm{E}-05$ & $8.6743 \mathrm{E}-03$ \\
\hline FLUX & $234 \mathrm{U}$ & $235 \mathrm{U}$ & $236 \mathrm{U}$ & 90SR \\
\hline $2.7000 \mathrm{E}+15$ & $1.6326 \mathrm{E}-02$ & $2.8102 \mathrm{E}-03$ & $1.4012 \mathrm{E}-03$ & $4.6670 \mathrm{E}-03$ \\
\hline $3.0000 \mathrm{E}+15$ & $1.8040 \mathrm{E}-02$ & $3.1708 \mathrm{E}-03$ & $1.8028 \mathrm{E}-03$ & $5.2656 \mathrm{E}-03$ \\
\hline $3.3000 \mathrm{E}+1.5$ & $1.9610 E-02$ & $3.5048 \mathrm{E}-03$ & $2.2440 E-03$ & $5.8638 \mathrm{E}-03$ \\
\hline $3.6000 \mathrm{E}+15$ & $2.1037 \mathrm{E}-02$ & $3.8108 \mathrm{E}-03$ & $2.7194 \mathrm{E}-03$ & $6.4612 \mathrm{E}-03$ \\
\hline $3.9000 E+15$ & $2.2325 \mathrm{E}-02$ & $4.0890 \mathrm{E}-03$ & $3.2235 \mathrm{E}-03$ & $7.0576 \mathrm{E}-03$ \\
\hline $4.2000 E+15$ & $2.3477 \mathrm{E}-02$ & 4.3397E-03 & $3.7510 \mathrm{E}-03$ & $7.6523 \mathrm{E}-03$ \\
\hline $4.5000 \mathrm{E}+15$ & $2.4500 \mathrm{E}-02$ & $4.5641 \mathrm{E}-03$ & $4.2970 \mathrm{E}-03$ & $8.2450 \mathrm{E}-03$ \\
\hline $4.8000 \mathrm{E}+15$ & $2.5402 \mathrm{E}-02$ & $4.7633 \mathrm{E}-03$ & $4.8567 \mathrm{E}-03$ & $8.8352 \mathrm{E}-03$ \\
\hline $5.1000 \mathrm{E}+15$ & $2.6191 \mathrm{E}-02$ & $4.9390 \mathrm{E}-03$ & $5.4258 \mathrm{E}-03$ & $9.4224 \mathrm{E}-03$ \\
\hline $5.4000 E+15$ & $2.6875 \mathrm{E}-02$ & $5.0926 \mathrm{E}-03$ & $6.0004 E-03$ & $1.0006 \mathrm{E}-02$ \\
\hline FLUX & 95ZR & 106RU & $137 \mathrm{CS}$ & $144 \mathrm{CE}$ \\
\hline $2.7000 \mathrm{E}+15$ & $2.6872 \mathrm{E}-03$ & $1.7633 \mathrm{E}-04$ & $4.7432 \mathrm{E}-03$ & $2.9511 E-03$ \\
\hline $3.0000 \mathrm{E}+15$ & $3.0286 \mathrm{E}-03$ & $2.0141 \mathrm{E}-04$ & $5.3625 \mathrm{E}-03$ & $3.3438 \mathrm{E}-03$ \\
\hline $3.3000 E+15$ & $3.3707 \mathrm{E}-03$ & $2.2702 \mathrm{E}-04$ & $5.9838 \mathrm{E}-03$ & $3.7398 \mathrm{E}-03$ \\
\hline $3.6000 \mathrm{E}+15$ & $3.7133 \mathrm{E}-03$ & $2.5311 \mathrm{E}-04$ & $6.6067 \mathrm{E}-03$ & $4.1384 \mathrm{E}-03$ \\
\hline $3.9000 E+15$ & $4.0559 \mathrm{E}-03$ & $2.7963 \mathrm{E}-04$ & $7.2308 \mathrm{E}-03$ & $4.5391 E-03$ \\
\hline $4.2000 E+15$ & $4.3983 \mathrm{E}-03$ & $3.0652 \mathrm{E}-04$ & $7.8556 \mathrm{E}-03$ & $4.9414 \mathrm{E}-03$ \\
\hline $4.5000 \mathrm{E}+15$ & $4.7400 \mathrm{E}-03$ & $3.3374 \mathrm{E}-04$ & $8.4805 \mathrm{E}-03$ & $5.3447 \mathrm{E}-03$ \\
\hline $4.8000 E+15$ & $5.0805 \mathrm{E}-03$ & $3.6123 \mathrm{E}-04$ & $9.1050 \mathrm{E}-03$ & $5.7483 E-03$ \\
\hline $5.1000 \mathrm{E}+15$ & $5.4194 \mathrm{E}-03$ & $3.8895 \mathrm{E}-04$ & $9.7285 \mathrm{E}-03$ & $6.1517 \mathrm{E}-03$ \\
\hline $5.4000 \mathrm{E}+15$ & $5.7563 \mathrm{E}-03$ & $4.1683 \mathrm{E}-04$ & $1.0350 \mathrm{E}-03$ & $6.5543 \mathrm{E}-03$ \\
\hline FLUX & $125 \mathrm{SB}$ & FIMA & & \\
\hline $2.7000 \mathrm{~F}+15$ & $6.7590 \mathrm{E}-05$ & $7.1061 \mathrm{E}-02$ & & \\
\hline $3.0000 \mathrm{E}+15$ & $7.5296 \mathrm{E}-05$ & $8.0522 \mathrm{E}-02$ & & \\
\hline $3.3000 \mathrm{E}+15$ & $8.2794 \mathrm{E}-05$ & $9.0060 \mathrm{E}-02$ & & \\
\hline $3.6000 \mathrm{E}+15$ & $9.0094 \mathrm{E}-05$ & $9.9669 \mathrm{E}-02$ & & \\
\hline $3.9000 \mathrm{E}+15$ & $9.7206 \mathrm{E}-05$ & $1.0934 \mathrm{E}-01$ & & \\
\hline $4.2000 E+15$ & $1.0414 \mathrm{E}-04$ & $1.1907 \mathrm{E}-01$ & & \\
\hline $4.5000 E+15$ & $1.1090 \mathrm{E}-04$ & $1.2884 \mathrm{E}-01$ & & \\
\hline $4.8000 E+15$ & $1.1750 \mathrm{E}-04$ & $1.3865 \mathrm{E}-01$ & & \\
\hline $5.1000 E+15$ & $1.2394 \mathrm{E}-04$ & $1.4848 \mathrm{E}-01$ & & \\
\hline $5.4000 \mathrm{E}+15$ & $1.3023 \mathrm{E}-04$ & $1.5833 \mathrm{E}-01$ & & \\
\hline
\end{tabular}


Table B.9. Fission product inventories in Biso-coated $\mathrm{ThO}_{2}$ particles from irradiation capsule $\mathrm{HT}-15$, calculated for various neutron flux levels (atoms per initial atom of thorium)

\begin{tabular}{|c|c|c|c|c|}
\hline $\begin{array}{c}\text { FLUX } \\
2.7000 \mathrm{E}+15 \\
3.0000 \mathrm{E}+15 \\
3.3000 \mathrm{E}+15 \\
3.6000 \mathrm{E}+15 \\
3.9000 \mathrm{E}+15 \\
4.2000 \mathrm{E}+15 \\
4.5000 \mathrm{E}+15 \\
4.8000 \mathrm{E}+15 \\
5.1000 \mathrm{E}+15 \\
5.4000 \mathrm{E}+15\end{array}$ & $\begin{array}{c}232 \mathrm{TH} \\
8.5067 \mathrm{E}-01 \\
8.3552 \mathrm{E}-01 \\
8.2064 \mathrm{E}-01 \\
8.0602 \mathrm{E}-01 \\
7.9167 \mathrm{E}-01 \\
7.7757 \mathrm{E}-01 \\
7.6372 \mathrm{E}-01 \\
7.5012 \mathrm{E}-01 \\
7.3676 \mathrm{E}-01 \\
7.2364 \mathrm{E}-01\end{array}$ & $\begin{array}{c}233 \mathrm{PA} \\
2.4707 \mathrm{E}-02 \\
2.6345 \mathrm{E}-02 \\
2.7823 \mathrm{E}-02 \\
2.9156 \mathrm{E}-02 \\
3.0355 \mathrm{E}-02 \\
3.1429 \mathrm{E}-02 \\
3.2390 \mathrm{E}-02 \\
3.3245 \mathrm{E}-02 \\
3.4002 \mathrm{E}-02 \\
3.4670 \mathrm{E}-02\end{array}$ & $\begin{array}{c}234 \mathrm{PA} \\
3.5244 \mathrm{E}-05 \\
4.0976 \mathrm{E}-05 \\
4.6732 \mathrm{E}-05 \\
5.2462 \mathrm{E}-05 \\
5.8124 \mathrm{E}-05 \\
6.3686 \mathrm{E}-05 \\
6.9120 \mathrm{E}-05 \\
7.4405 \mathrm{E}-05 \\
7.9523 \mathrm{E}-05 \\
8.4461 \mathrm{E}-05\end{array}$ & $\begin{array}{c}233 \mathrm{U} \\
1.2008 \mathrm{E}-02 \\
1.1508 \mathrm{E}-02 \\
1.1027 \mathrm{E}-02 \\
1.0568 \mathrm{E}-02 \\
1.0130 \mathrm{E}-02 \\
9.7153 \mathrm{E}-03 \\
9.3215 \mathrm{E}-03 \\
8.9481 \mathrm{E}-03 \\
8.5940 \mathrm{E}-03 \\
8.2582 \mathrm{E}-03\end{array}$ \\
\hline $\begin{array}{c}\text { FLUX } \\
2.7000 \mathrm{E}+15 \\
3.0000 \mathrm{E}+15 \\
3.3000 \mathrm{E}+15 \\
3.6000 \mathrm{E}+15 \\
3.9000 \mathrm{E}+15 \\
4.2000 \mathrm{E}+15 \\
4.5000 \mathrm{E}+15 \\
4.8000 \mathrm{E}+15 \\
5.1000 \mathrm{E}+15 \\
5.4000 \mathrm{E}+15\end{array}$ & $\begin{array}{c}234 \mathrm{U} \\
1.7793 \mathrm{E}-02 \\
1.9418 \mathrm{E}-02 \\
2.0866 \mathrm{E}-02 \\
2.2142 \mathrm{E}-02 \\
2.3256 \mathrm{E}-02 \\
2.4220 \mathrm{E}-02 \\
2.5045 \mathrm{E}-02 \\
2.5742 \mathrm{E}-02 \\
2.6324 \mathrm{E}-02 \\
2.6800 \mathrm{E}-02\end{array}$ & $\begin{array}{c}235 \mathrm{U} \\
3.1684 \mathrm{E}-03 \\
3.5164 \mathrm{E}-03 \\
3.8287 \mathrm{E}-03 \\
4.1060 \mathrm{E}-03 \\
4.3499 \mathrm{E}-03 \\
4.5624 \mathrm{E}-03 \\
4.7456 \mathrm{E}-03 \\
4.9020 \mathrm{E}-03 \\
5.0339 \mathrm{E}-03 \\
5.1435 \mathrm{E}-03\end{array}$ & $\begin{array}{c}236 \mathrm{U} \\
1.9430 \mathrm{E}-03 \\
2.4606 \mathrm{E}-03 \\
3.0183 \mathrm{E}-03 \\
3.6082 \mathrm{E}-03 \\
4.2226 \mathrm{E}-03 \\
4.8546 \mathrm{E}-03 \\
5.4978 \mathrm{E}-03 \\
6.1464 \mathrm{E}-03 \\
6.7954 \mathrm{E}-03 \\
7.4403 \mathrm{E}-03\end{array}$ & $\begin{array}{c}90 \mathrm{SR} \\
5.8597 \mathrm{E}-03 \\
6.5805 \mathrm{E}-03 \\
7.2971 \mathrm{E}-03 \\
8.0089 \mathrm{E}-03 \\
8.7154 \mathrm{E}-03 \\
9.4160 \mathrm{E}-03 \\
1.0110 \mathrm{E}-02 \\
1.0797 \mathrm{E}-02 \\
1.1477 \mathrm{E}-02 \\
1.2149 \mathrm{E}-02\end{array}$ \\
\hline $\begin{array}{c}\text { FLUX } \\
2.7000 \mathrm{E}+15 \\
3.0000 \mathrm{E}+15 \\
3.3000 \mathrm{E}+15 \\
3.6000 \mathrm{E}+15 \\
3.9000 \mathrm{E}+15 \\
4.2000 \mathrm{E}+15 \\
4.5000 \mathrm{E}+15 \\
4.8000 \mathrm{E}+15 \\
5.1000 \mathrm{E}+15 \\
5.4000 \mathrm{E}+15\end{array}$ & $\begin{array}{c}95 \mathrm{ZR} \\
3.0680 \mathrm{E}-03 \\
3.4400 \mathrm{E}-03 \\
3.8102 \mathrm{E}-03 \\
4.1783 \mathrm{E}-03 \\
4.5439 \mathrm{E}-03 \\
4.9063 \mathrm{E}-03 \\
5.2651 \mathrm{E}-03 \\
5.6199 \mathrm{E}-03 \\
5.9702 \mathrm{E}-03 \\
6.3157 \mathrm{E}-03\end{array}$ & $\begin{array}{c}106 \mathrm{RU} \\
2.1914 \mathrm{E}-04 \\
2.4923 \mathrm{E}-04 \\
2.7978 \mathrm{E}-04 \\
3.1073 \mathrm{E}-04 \\
3.4199 \mathrm{E}-04 \\
3.7351 \mathrm{E}-04 \\
4.0520 \mathrm{E}-04 \\
4.3701 \mathrm{E}-04 \\
4.6887 \mathrm{E}-04 \\
5.0073 \mathrm{E}-04\end{array}$ & $\begin{array}{c}137 \mathrm{CS} \\
5.9695 \mathrm{E}-03 \\
6.7191 \mathrm{E}-03 \\
7.4675 \mathrm{E}-03 \\
8.2142 \mathrm{E}-03 \\
8.9585 \mathrm{E}-03 \\
9.6997 \mathrm{E}-03 \\
1.0437 \mathrm{E}-02 \\
1.1170 \mathrm{E}-02 \\
1.1898 \mathrm{E}-02 \\
1.2621 \mathrm{E}-02\end{array}$ & $\begin{array}{c}144 \mathrm{CE} \\
3.6201 \mathrm{E}-03 \\
4.0827 \mathrm{E}-03 \\
4.5463 \mathrm{E}-03 \\
5.0101 \mathrm{E}-03 \\
5.4735 \mathrm{E}-03 \\
5.9355 \mathrm{E}-03 \\
6.3956 \mathrm{E}-03 \\
6.8530 \mathrm{E}-03 \\
7.3070 \mathrm{E}-03 \\
7.7570 \mathrm{E}-03\end{array}$ \\
\hline $\begin{array}{c}\text { FLUX } \\
2.7000 \mathrm{E}+15 \\
3.0000 \mathrm{E}+15 \\
3.3000 \mathrm{E}+15 \\
3.6000 \mathrm{E}+15 \\
3.9000 \mathrm{E}+15 \\
4.2000 \mathrm{E}+15 \\
4.5000 \mathrm{E}+15 \\
4.8000 \mathrm{E}+15 \\
5.1000 \mathrm{E}+15 \\
5.4000 \mathrm{E}+15\end{array}$ & $\begin{array}{c}125 \mathrm{SB} \\
8.3633 \mathrm{E}-05 \\
9.2688 \mathrm{E}-05 \\
1.0145 \mathrm{E}-04 \\
1.0994 \mathrm{E}-04 \\
1.1816 \mathrm{E}-04 \\
1.2614 \mathrm{E}-04 \\
1.3387 \mathrm{E}-04 \\
1.4139 \mathrm{E}-04 \\
1.4868 \mathrm{E}-04 \\
1.5577 \mathrm{E}-04\end{array}$ & $\begin{array}{c}\text { FIMA } \\
8.9676 \mathrm{E}-02 \\
1.0119 \mathrm{E}-01 \\
1.1275 \mathrm{E}-01 \\
1.2434 \mathrm{E}-01 \\
1.3596 \mathrm{E}-01 \\
1.4759 \mathrm{E}-01 \\
1.5921 \mathrm{E}-01 \\
1.7082 \mathrm{E}-01 \\
1.8241 \mathrm{E}-01 \\
1.9396 \mathrm{E}-01\end{array}$ & & \\
\hline
\end{tabular}




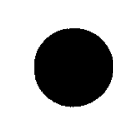

I

$+$

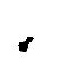

3

$+$

0 
ORNL/TM-5305

Distribution Category UC-77

\section{INTERNAL DISTRIBUTION}

1-3. Central Research Library

4. Document Reference Section

5-14. Laboratory Records Department

15. Laboratory Records, ORNL RC

16. ' ORNL Patent Office

17. R. L. Beatty

18. R. A. Bradley

19. A. J. Caputo

20. C. F. Coleman

21. J. A. Conlin

22. J. H. Coobs

23. D. Costanzo

24. R. G. Donnelly

25. W. P. Eatherly

26. J. I. Federer

27. D. E. Ferguson

28. R. L. Hamner

29. R. F. Hibbs

30-32. M. R. Hill

33. F. J. Homan

34. D. R. Johnson

35-37. M. J. Kania

38-39. P. R. Kasten

40. H. T. Kerr

41. W. J. Lackey, Jr.

42. C. E. Lamb

43-45. T. B. Lindemer

46. E. L. Long, Jr.

47. R. A. Lorenz

48. A. L. Lotts

49. R. E. MacPherson

50. J. C. Mailen
51. A. P. Malinauskas

52. W. J. McDowell

53. B. H. Montgomery

54. C. S. Morgan

55-57. M. T. Morgan

58. K. J. Notz

59. G. W. Parker

60. R. L. Pearson

61. W. H. Pechin

62. H. Postma

63. W. W. Proaps

64-66. J. M. Robbins

67. J. L. Scott

68. J. D. Sease

69. R. L. Shepard

70. T. N. Tiegs

71. K. R. Thoms

72. V.C.A. Vaughen

73. J. E. Van Cleve, Jr.

74. J. R. Weir

75. R. P. Wichner

76. R. G. Wymer

77. P. M. Brister (consultant)

78. K. W. Davis (CTD consultant)

79. E. L. Gaden, Jr. (CTD consultant)

80. C. H. Ice (CTD consultant)

81. John Moteff (consultant)

82. Hayne Palmour III (consultant)

83. J. W. Prados (consultant)

84. N. E. Promisel (consultant)

85. R. B. Richards (CTD consultant)

86. D. F. Stein (consultant) 


\section{EXTERNAL DISTRIBUTION}

87-94. ERDA DIVISION OF NUCLEAR FUEL CYCLE AND PRODUCTION, Washington, DC 20545

Director (2)

R. G. Bradley (1)

W. S. Schieb (5)

95-96. ERDA DIVISION OF REACTOR NUCLEAR RESEARCH AND APPLICATIONS, Washington, DC 20545

Director

97-98. ERDA IDAHO OPERATIONS OFFICE, P.O. Box 2108, Idaho Falls, ID 83401

C. E. Williams, Manager

Barry Smith

99. ERDA OFFICE OF PROGRAM MANAGEMENT, RESEARCH AND SPACE PROGRAMS, P.O. Box 81325, San Diego, CA 92138

J. B. Radcliffe

100. ERDA SAN FRANCISCO OPERATIONS OFFICE, 1333 Broadway, Wells Fargo Bldg., Oakland, CA 94612

R. D. Thorne, Manager

101-103. ERDA OAK RIDGE OPERATIONS OFFICE, P.O. Box E, Oak Ridge, TN 37830

Director, Research and Technical Support Division

Director, Reactor Division

F. E. Dearing, Reactor Division

104-279. ERDA TECHNICAL INFORMATION CENTER, P.O. Box 62, Oak Ridge, TN 37830

For distribution as shown in TID-4500 Distribution Category, UC-77-Gas-Cooled Reactor Technology

280-287. Copies-ERDA Exchange Agreements with Germany and Dragon Project 